\author{
Gysele Lima Ricci
}

\title{
DESEMPENHO E CONTROLE EM PEQUENAS E MÉDIAS EMPRESAS: \\ ESTUDO DO SETOR HOTELEIRO DA REGIÃO CENTRAL \\ DO ESTADO DE SÃO PAULO
}

\begin{abstract}
Dissertação apresentada á Escola de Engenharia de São Carlos da Universidade de São Paulo, como parte dos requisitos para obtenção do título de Mestre em Engenharia de Produção.
\end{abstract}

Orientador: Prof. Dr. Edmundo Escrivão Filho.

\section{São Carlos}

Janeiro de 2010 
AUTORIZO A REPRODUÇÃO E DIVULGAÇÃO TOTAL OU PARCIAL DESTE TRABALHO, POR QUALQUER MEIO CONVENCIONAL OU ELETRÔNICO, PARA FINS DE ESTUDO E PESQUISA, DESDE QUE CITADA A FONTE.

Ficha catalográfica preparada pela Seção de Tratamento da Informaçăo do Serviço de Biblioteca - EESC/USP

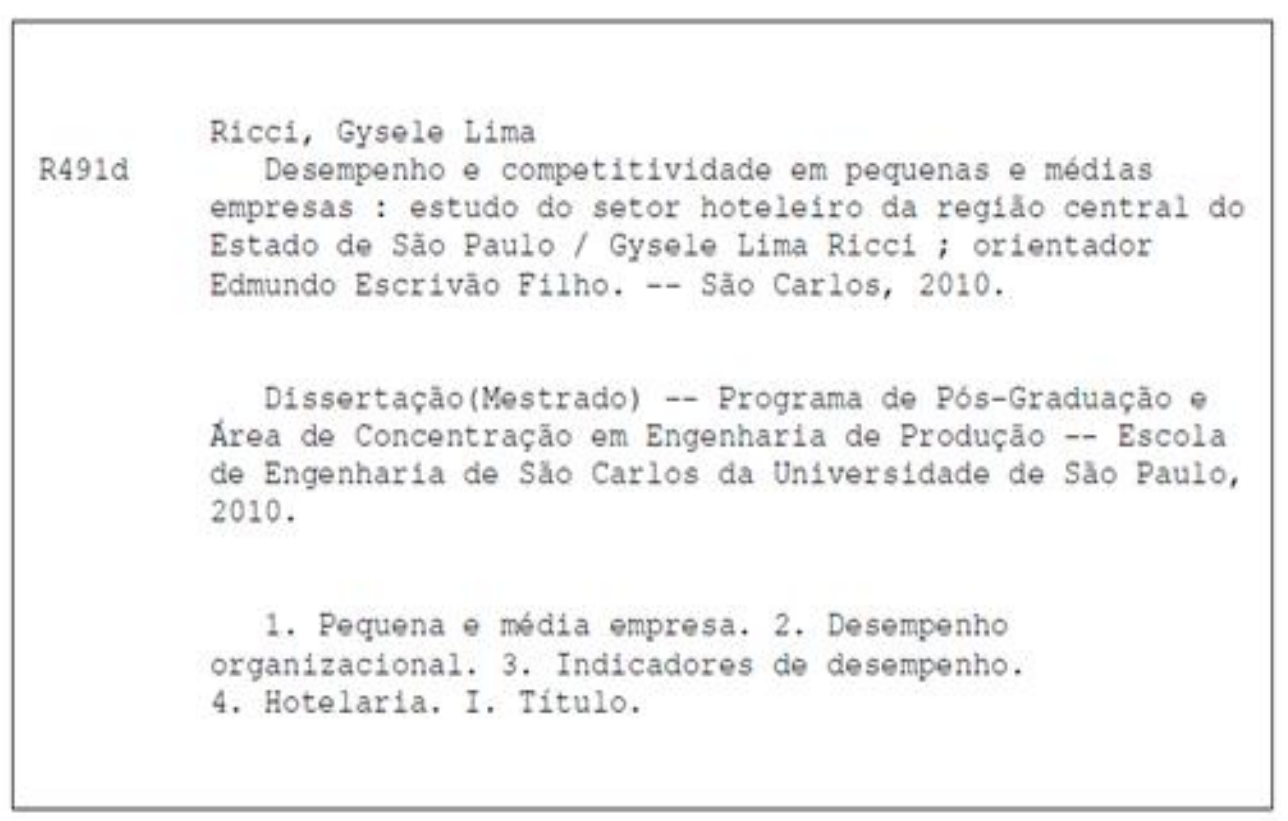




\section{FOLHA DE JULGAMENTO}

\section{Candidato: Bacharel GYSELE LIMA RICCI.}

Dissertação defendida e julgada em 08/02/2010 perante a Comissão Julgadora:

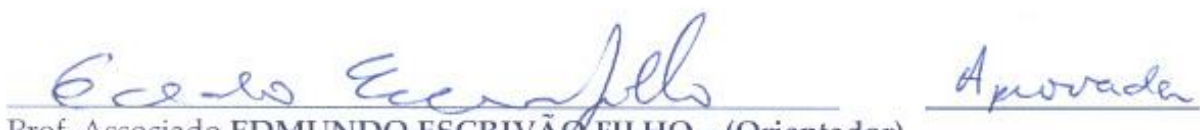

Prof. Associado EDMUNDO ESCRIVÃ 0 FILHO - (Orientador)

(Escola de Engenharia de São Carlos/USP)

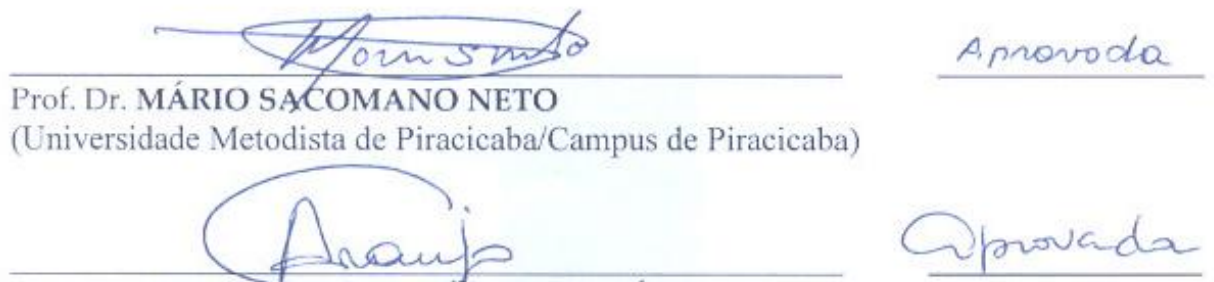

Prof ${ }^{2}$. Drª. CINTIA REJANE MOLLER ARAÚJO

(Universidade Federal de São Carlos/Campus de Sorocaba)

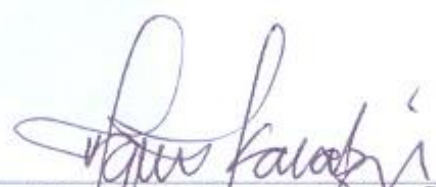

Prof. Associado AQUIIES ELIE GUMARÃES KALATZIS

Coordenador do Programa de Pós-draduação em

Engenharia de Produção

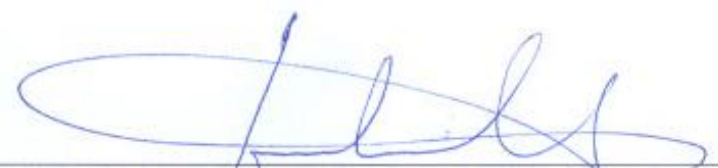

Prof. Titular GERALDO ROBERTO MARTINS DA COSTA

Presidente da Condissão da Pós-Graduação da EESC 
Dedico este trabalho a Deus e aos meus pais... Benedito e Dilma 


\section{AGRADECIMENTOS}

Ao meu orientador e amigo, Professor Edmundo Escrivão Filho, pelo encaminhamento, análise, suporte e dedicação dispensada para a melhoria do projeto.

Aos membros da banca examinadora, pelas observações, críticas e elogios, com os quais se chegou a uma versão final de maior qualidade.

Aos professores do PPGEP que ajudaram na minha formação teórica, por meio de suas disciplinas.

Aos colegas de mestrado e doutorado do Departamento de Engenharia de Produção da EESC-USP que, pelas discussões em aula, contribuíram para a construção desta dissertação.

Aos colegas do GEOPE que ajudaram com sugestões e indicações numa rica troca de experiências.

À Fundação de Amparo à Pesquisa de São Paulo - FAPESP - pelo apoio ao desenvolvimento da pesquisa.

Aos dirigentes dos hotéis que colaboraram com a pesquisa e que serviram de casos para este trabalho.

Ao Diretor de Fomento ao Turismo de São Carlos, Emiliano Saran Azevedo, e ao Prof Mário Carlos Beni, que foram muito atenciosos disponibilizando informações e parte de seus tempos, já tão restritos.

Ao meu namorado, Júnior, pela amizade, motivação e ajuda proporcionada em todos os momentos. Seu apoio foi fundamental para a finalização deste processo.

Aos meus pais, pela educação proporcionada, pelos valores transmitidos e pelo incentivo que sempre deram para o estudo.

A toda minha família e meus amigos, pela força durante esta jornada.

A todas as pessoas que contribuíram direta ou indiretamente para a concretização deste trabalho. 
$O$ ato da conquista de um grande sonho reflete o sucesso nas lutas diárias para alcançá-lo.

Kléber Novartes 


\section{RESUMO}

RICCI, Gysele Lima Desempenho e competitividade em pequenas e médias empresas: estudo do setor hoteleiro da região central do Estado de São Paulo. 2010. 222 p. Dissertação (Mestrado) - Escola de Engenharia de São Carlos, Universidade de São Paulo, São Carlos, 2010.

O objetivo geral desta pesquisa foi avaliar a existência de uma orientação do controle do desempenho utilizados nas pequenas e médias empresas hoteleiras e sua adequação aos fatores-chave de competitividade do setor. Essa pesquisa foi realizada na Região Central do Estado de São Paulo contemplando os Circuitos Paulista da Chapada Guarani e Ecocaipira. A pesquisa fundamenta-se no vácuo existente entre a visão estratégica e visão operacional na gestão empresarial, ou seja, a falta de integração entre as diretrizes estratégicas e a operação das empresas. A medição de desempenho é uma atividade que visa melhorar gradativamente a atuação das empresas, fazendo com que elas se mantenham competitivas. O trabalho de campo foi dividido em três fases: a primeira e segunda fase concentrou-se na abordagem quantitativa. A primeira fase teve o propósito de identificar a quantidade de empresas hoteleiras na região central do Estado de São Paulo, considerando o mapeamento da equipe de pesquisadores do GEOPE da EESC - USP. A segunda fase teve o propósito de caracterizar a preocupação com o controle do desempenho e com as medidas de desempenho da organização. A terceira fase concentrou-se na abordagem qualitativa, na qual foi feito um estudo de caso com o propósito de verificar os indicadores utilizados pelas empresas e verificar se estão orientados para a competitividade. Como principal resultado, observou-se que os mecanismos de controle do desempenho são adequados as características do contexto social de cada organização e, como consequiência, está relacionado à estratégia da empresa. Ainda, concluiu-se que os indicadores de desempenho das grandes e das pequenas empresas hoteleiras são semelhantes, a diferença está na formalização desses indicadores.

Palavras-chave: Pequena e média empresa. Controle do desempenho. Indicadores de desempenho. Hotelaria. 


\section{ABSTRACT}

RICCI, Gysele Lima. Performance and competitiveness in small and medium - sized enterprises: study of the hotel sector of the central region of São Paulo State. 2010. 222p. Master Dissertation - Engineering School of São Carlos, University of São Paulo, São Carlos, 2010.

The general aim of this research is to evaluate the existence of an orientation of the organizational control utilized in small and medium - sized hotels and its adequacy for the key competitivity factors of the sector. The research was conducted in the central region of São Paulo State comprising the Paulista Circuits of Chapada Guarani and Ecocaipira, based on the vacuum that exists between the strategic and operational visions in the entrepreneural management, i. e., the lack of integration between the strategic guidelines and the operation of the enterprises. The performance measurement is an activity that aims to gradually improve the action of enterprises, so that they keep themselves competitive, which is the basis in the strategic process. The field work was divided into three stages, of which the first and the second focused on the quantitative approach. In the first phase the aim was the identification and quantification of hotels in the central region of São Paulo state, considering the mapping of the research group of GEOPE at São Carlos Engineering School-USP. In the second phase, the concern about the performance control and measurement of the organization was characterized. Finally, the third phase focused on the qualitative approach, in which a case study was conducted in order to verify the indicators utilized by the enterprises and check that they are oriented towards competitiveness. As a main result, it was possible to observe that the performance control mechanisms are adequate for the characteristics of the social context of each organization and, therefore, related to the enterprise strategy. The performance indicators of large and small hotels are similar, differing only in their formalization.

Keywords: Small and medium - sized enterprise; Performance control; Performance indicators. Hotel. 


\section{LISTA DE FIGURAS}

Figura 2.1: A Dupla Atribuição do Planejamento .......................................................... 32

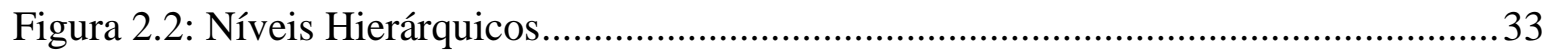

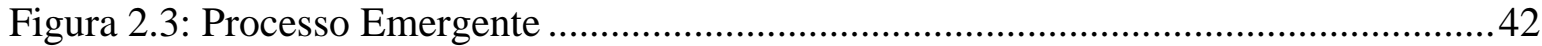

Figura 2.4: Estratégias Deliberada e Emergente ........................................................43

Figura 3.1: A Interação das Dimensões Contextual e Estrutural do Projeto da

Organização ................................................................................. 48

Figura 3.2: Dupla Atribuição do Controle .................................................................51

Figura 3.3: Modelo de Controle pelo Feedback ..............................................................53

Figura 3.6: O Desdobramento da Estratégia................................................................57

Figura 3.7: A Medição de Desempenho Estratégico como Elemento de Ligação ..............58

Figura 3.8: As Perspectivas do Balanced Scorecard ..................................................62

Figura 3.9: Exemplos de indicadores desdobrados na estrutura organizacional ................65

Figura 4.1: Sobrevivência e Mortalidade das Empresas do Estado de São Paulo................74

Figura 4.2: Ferramenta para Descrever a Criação de Novas Empresas..............................8 80

Figura 4.3: Categorias de Especificidades de Gestão da Pequena Empresa ......................82

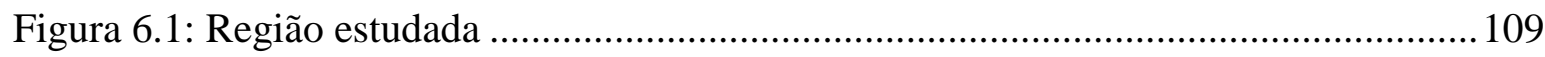

Figura 6.2: Organograma do HOTEL A .............................................................. 125

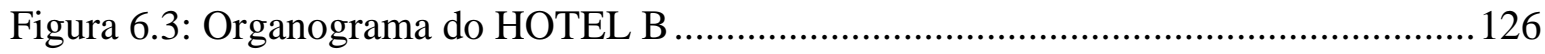

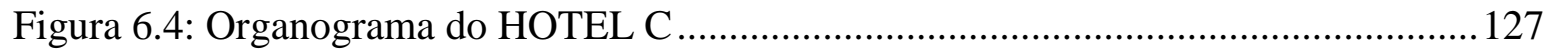

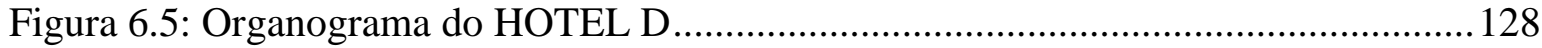

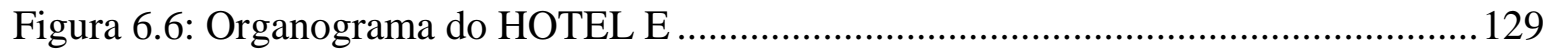

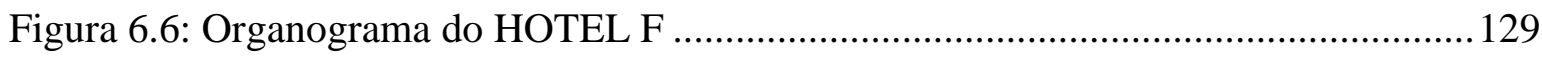

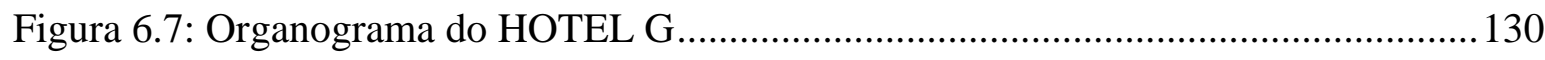




\section{LISTA DE GRÁFICOS}

Gráfico 6.1: Distribuição do Número de Hotéis pelas Cidades Estudadas ........................112

Gráfico 7.1: Indicadores de desempenho utilizados pelos hotéis pesquisados.................. 172 


\section{TABELAS}

Tabela 3.1: Principais critérios para geração de um indicador .......................................65

Tabela 6.1: Classificação dos hotéis por porte, segundo o número de unidades

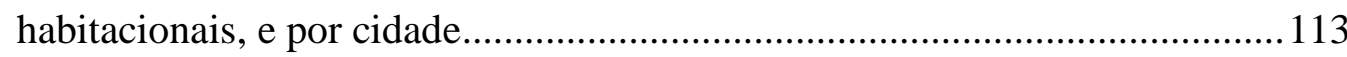

Tabela 6.2: Classificação das cidades dos circuitos paulistas x número de

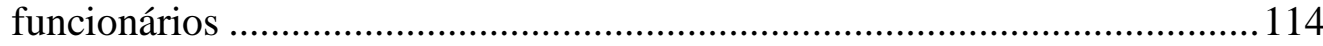

Tabela 6.2: Classificação dos hotéis por porte, cidade e segmento turístico, segundo o número de funcionários ................................................... 115 


\section{LISTA DE QUADROS}

Quadro 2.1: Elementos-Chave das Escolas do Design, Planejamento, Posicionamento, Empreendedora e Cognitiva ..........................................................28

Quadro 2.2: Elementos-Chave das Escolas do Aprendizado, Poder, Cultural, Ambiental e Configuração ...................................................................2 28

Quadro 3.1: Mudanças na Medição de Desempenho .......................................................56

Quadro 3.2: Modelos de Medição de Desempenho............................................................60

Quadro 3.3: Comparação dos Modelos de Medição de Desempenho ................................60

Quadro 3.4: Principais Indicadores de Desempenho do PNQ ........................................68

Quadro 4.1: Classficação das Empresas Segundo o Setor e o Número de Funcionários............................................................................ 71

Quadro 4.2: Especificidades Organizacionais, Decisionais e Individuais.........................76

Quadro 4.3: Modelo Organizacional/Especificidades das Pequenas Empresas ..................80

Quadro 5.1: Distinção entre Bens e Serviços ................................................................86

Quadro 5.2: Atividades Características do Turismo..........................................................91

Quadro 5.3: Componente da Oferta Turística ...........................................................93

Quadro 5.4: Relacionamento do Preço da Diária x Número de Estrelas............................97

Quadro 5.5: Categorias de Meios de Hospedagem de Turismo ......................................... 100

Quadro 5.6: Classificação Quanto ao Tamanho do Hotel ................................................ 100

Quadro 5.7: Classificação/Tipo de Meios de Hospedagem............................................. 101

Quadro 5.8: Principais Indicadores de Desempenho Utilizados pelos Hotéis ................... 106

Quadro 6.1: Classificação das empresas segundo o número de funcionários

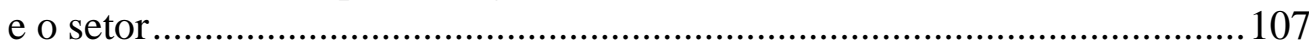

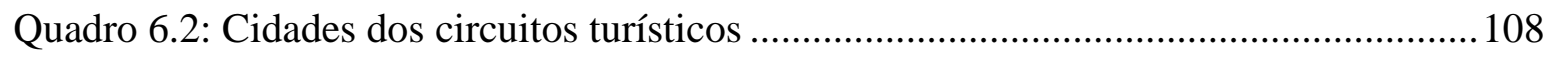

Quadro 6.3: Motivação turística para procura da região ................................................ 109

Quadro 6.4: Classificação das Empresas Segundo o Número de Unidades

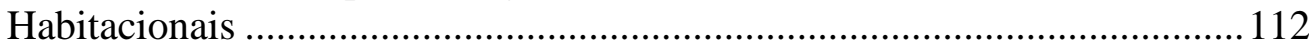

Quadro 6.5: Principais características das empresas estudadas ..................................... 125

Quadro 7.1: Definição do processo estratégico por hotel.............................................. 167

Quadro 7.2: Tipos de estratégia organizacional ...................................................... 168

Quadro 7.3: Nível e grau de formalização do planejamento .......................................... 168

Quadro 7.4: Tipos de controle do desempenho .......................................................... 169

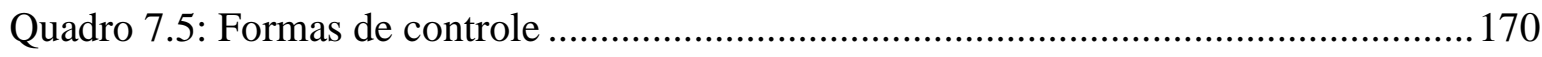


Quadro 7.6: Matriz de indicadores hoteleiros ............................................................. 171

Quadro 7.7: Matriz de indicadores hoteleiros ........................................................ 172

Quadro 7.8: Descrição das características dos dirigentes das empresas

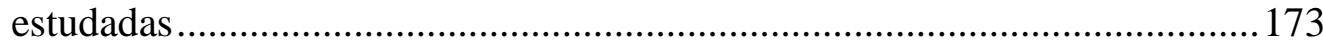

Quadro 7.9: Descrição das características organizacionais das empresas

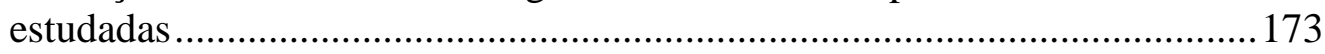

Quadro 7.10: Especificidades do setor hoteleiro que influenciam a gestão das empresas estudadas 


\section{LISTA DE ABREVIATURAS E SIGLAS}

ABIH - Associação Brasileira das Indústrias de Hotéis.

BSC - Balanced Scorecard.

CEMPRE - Cadastro Central de Empresas.

CNPJ - Cadastro Nacional da Pessoa Jurídica.

EESC - Escola de Engenharia de São Carlos.

EMBRATUR - Empresa Brasileira de Turismo.

FAPESP - Fundação de Amparo à Pesquisa de São Paulo.

GEOPE - Grupo de Estudos Organizacionais da Pequena Empresa.

HIA - Hotel Investment Advisors.

IBGE - Instituto Brasileiro de Geografia e Estatística.

IPMS - Integrated Performance Measurement Systems.

MD - Medição de Desempenho.

MDSI - Metodologia para la Definición y Selección de Indicadores.

OECD - Organização para a Cooperação e Desenvolvimento Econômico.

OMT - Organização Mundial do Turismo.
PE - Pequena Empresa.

PIB - Produto Interno Bruto.

PME - Pequena e Média Empresa.

PMS - Consistent Performance Management Systems.

PP - Performance Prism.

ROI - Retorno do Investimento.

SEBRAE/SP - Serviço de Apoio Brasileiro às Micro e Pequenas Empresas do Estado de São Paulo.

SEBRAE/GOIÁS - Serviço de Apoio Brasileiro às Micro e Pequenas Empresas do Estado de Goiás.

FUBRA - Fundação Universitária de Brasília.

SMART - Performance Pyramid.

SMD - Sistemas de Medição de Desempenho.

TQM - Performance Measurement Questionnaire.

UH - Unidade Habitacional.

USP - Universidade de São Paulo.

WTO - World Tourism Organization. 


\section{SUMÁRIO}

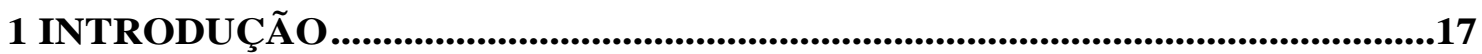

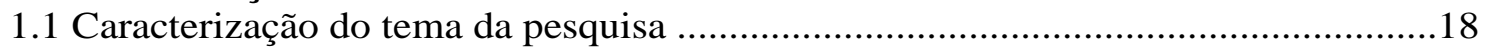

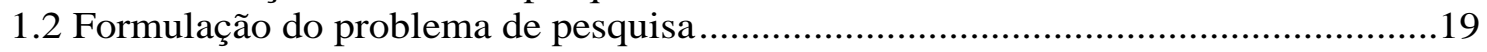

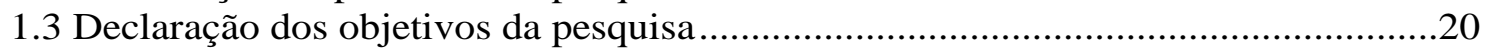

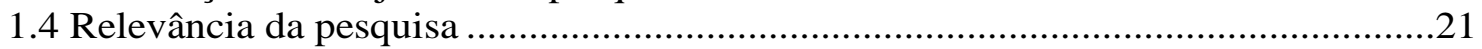

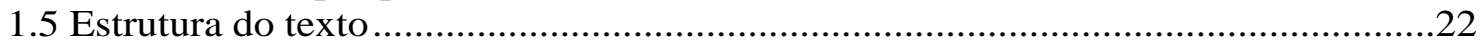

2 ESTRATÉgIA, PLANEJAMENTO E OBJETIVO ESTRATÉGICO ..............25

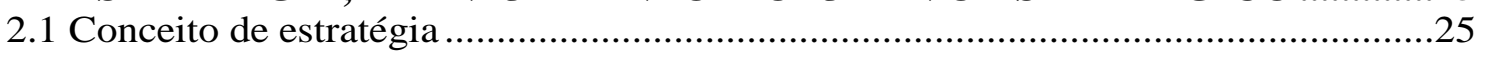

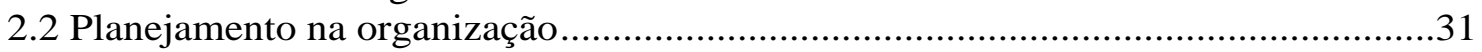

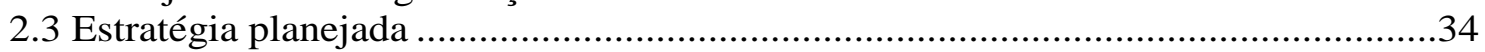

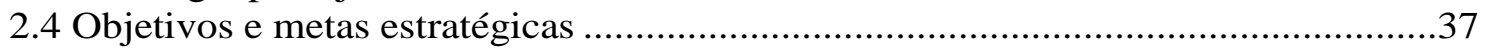

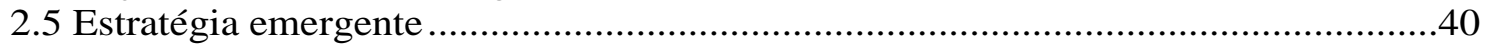

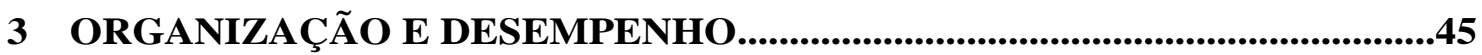

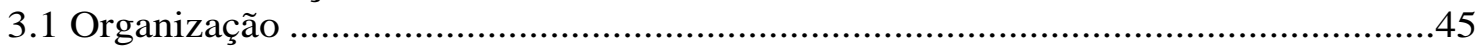

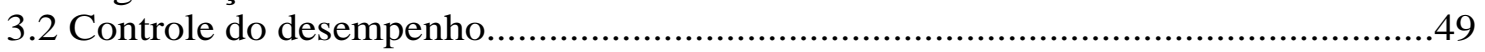

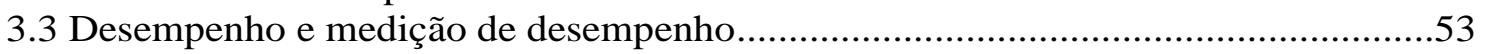

3.4 Nível Estratégico: medindo o cumprimento da orientação estratégica...................57

3.4.2 Modelos de medição de desempenho organizacional ........................................59

3.4.3 O nível tático: ligando o estratégico ao operacional .......................................61

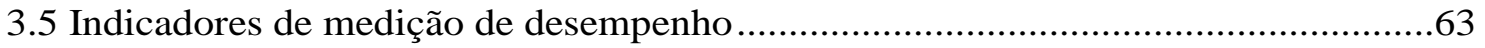

4 ESPECIFICIDADES DAS PEQUENAS E MÉDIAS EMPRESAS .......................71

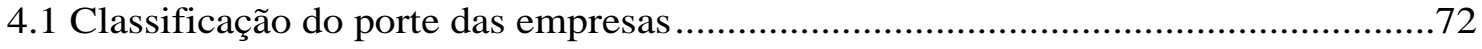

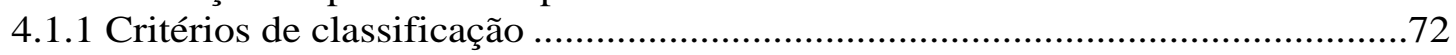

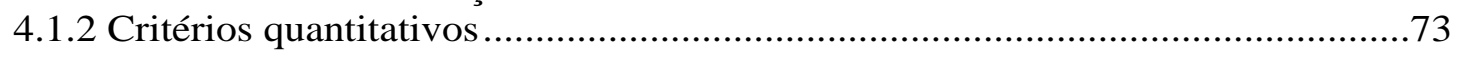

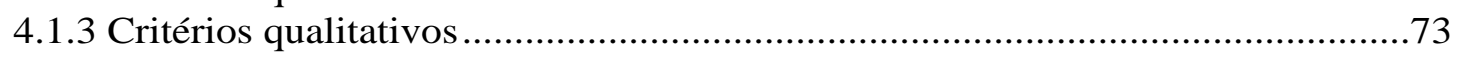

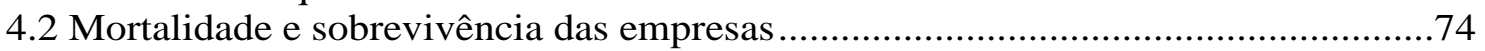

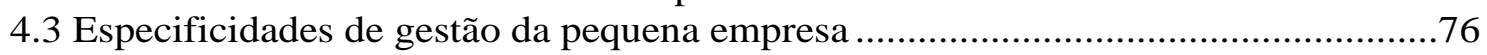

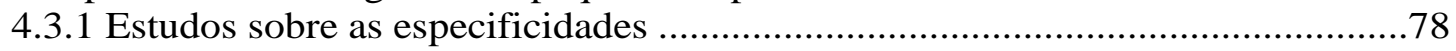

4.4 Medição de desempenho nas pequenas e médias empresas....................................83

5 SETOR DE SERVIÇOS: TURISMO E HOTELARIA .....................................87

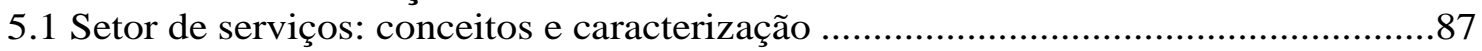

5.1.1 Prática administrativa no setor de serviços ........................................................90

5. 2 Turismo: conceitos e caracterização ..................................................................91

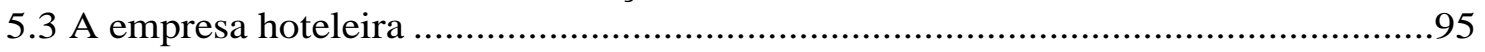

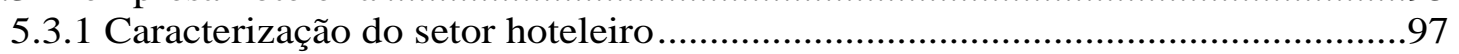

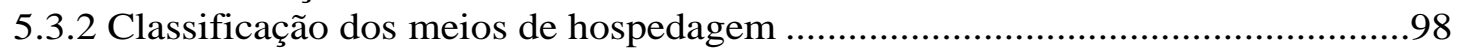

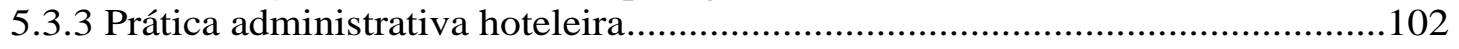

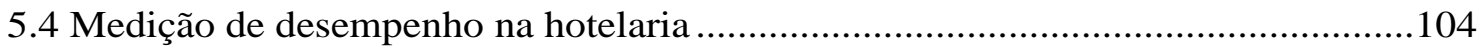

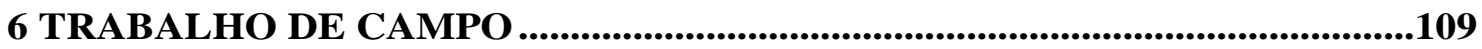

6.1 Métodos de pesquisa - primeira e segunda fases ....................................................

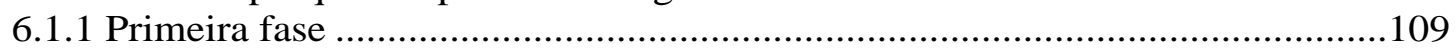

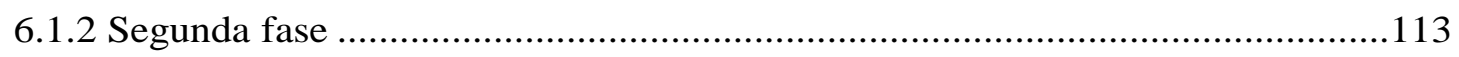

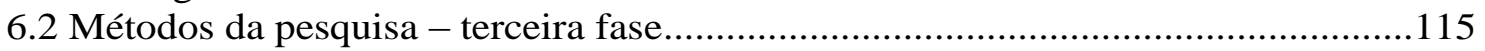

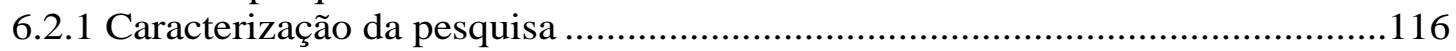

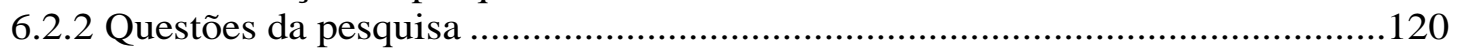




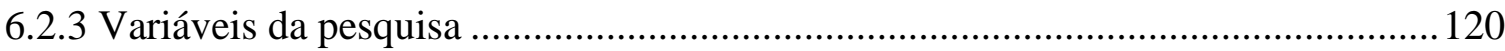

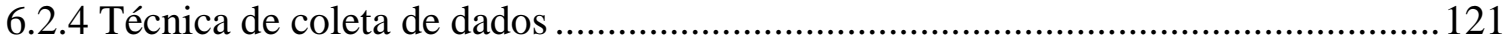

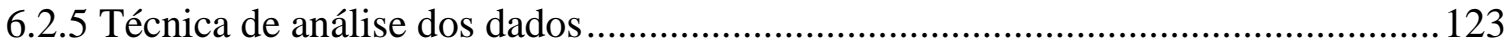

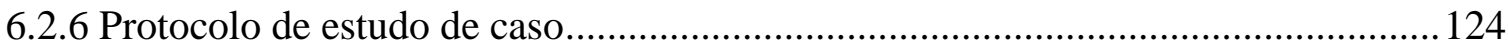

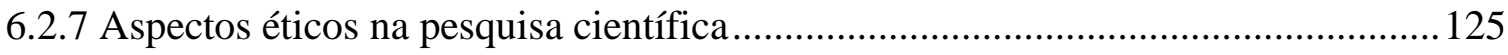

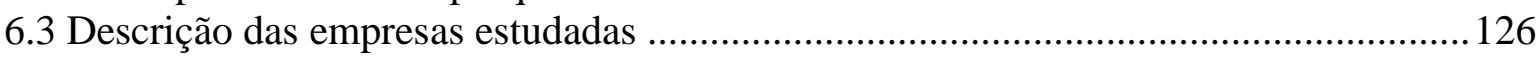

7 APRESENTAÇÃO E ANÁLISE DOS DADOS ...............................................135

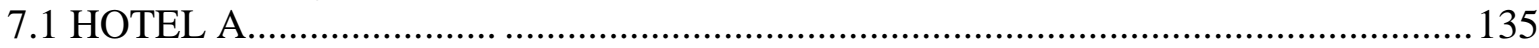

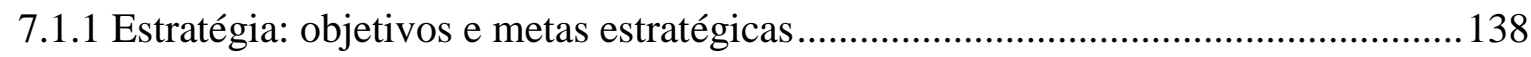

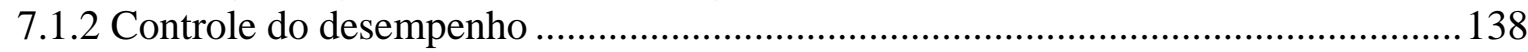

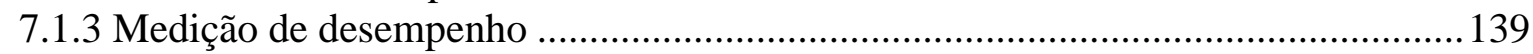

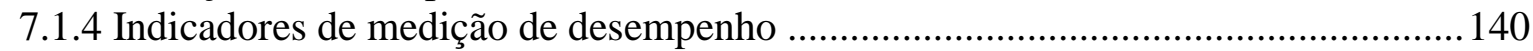

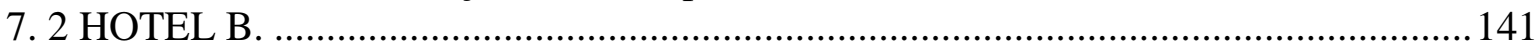

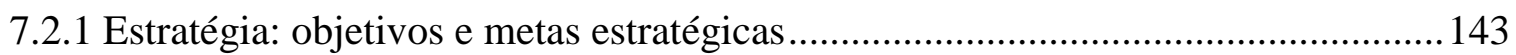

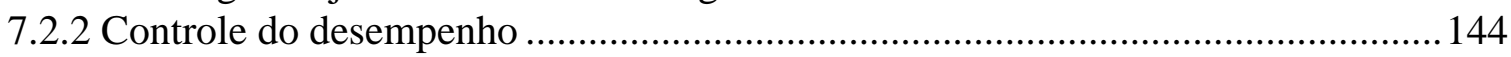

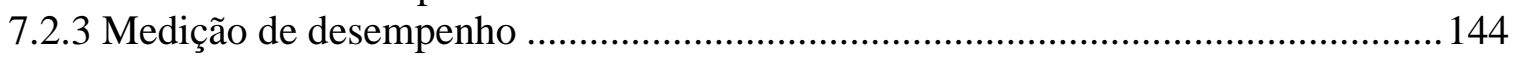

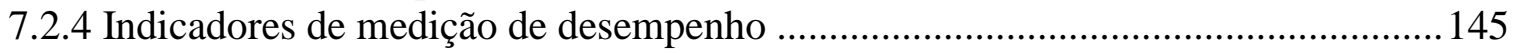

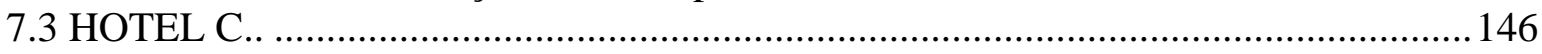

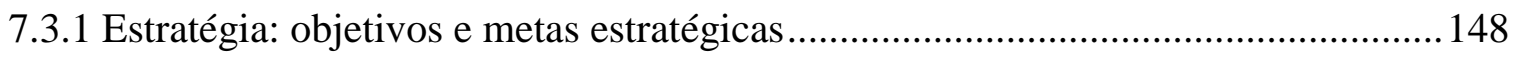

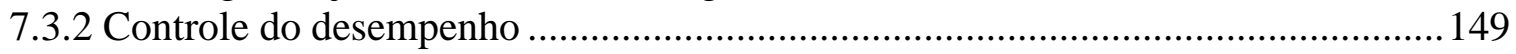

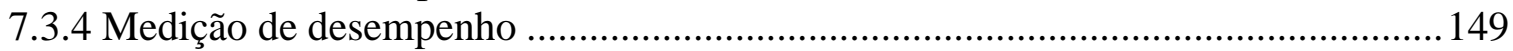

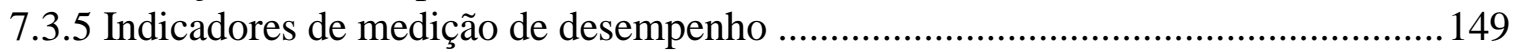

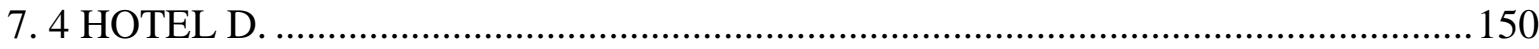

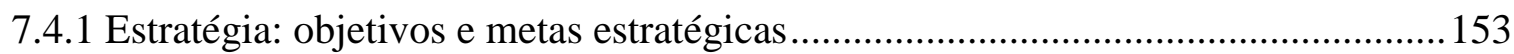

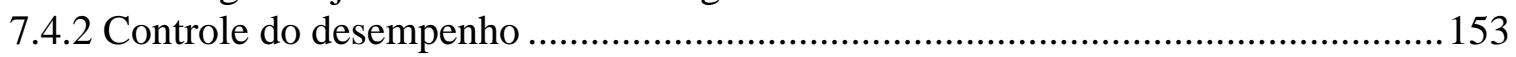

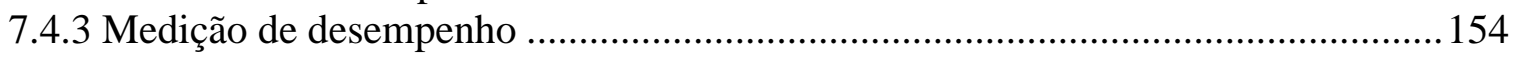

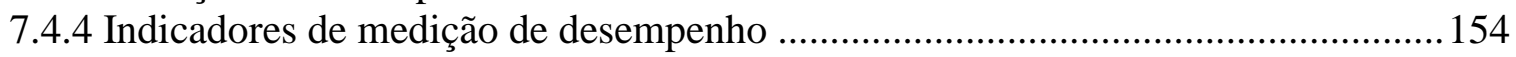

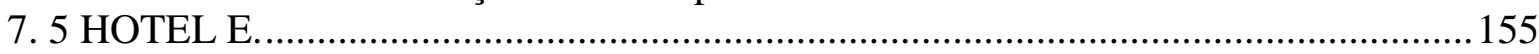

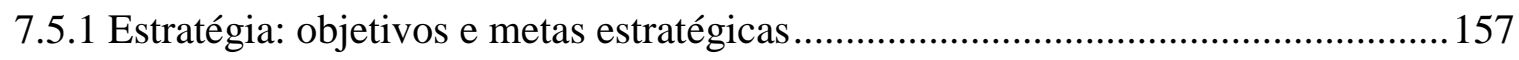

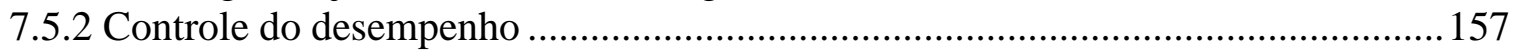

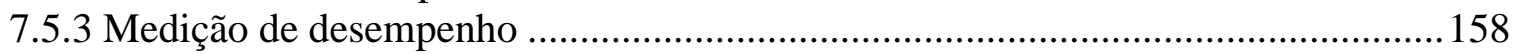

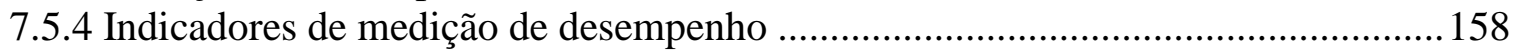

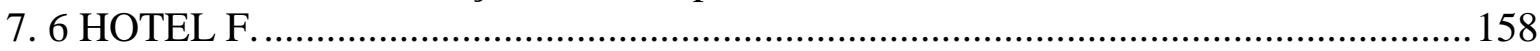

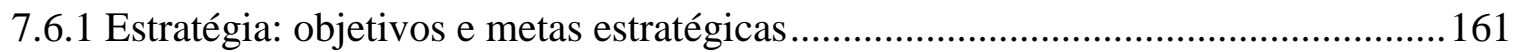

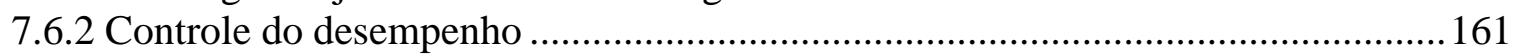

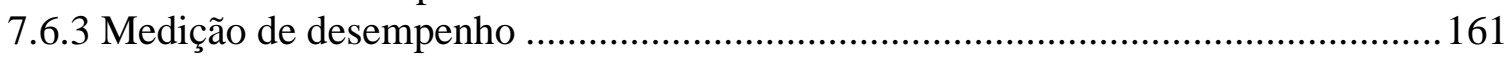

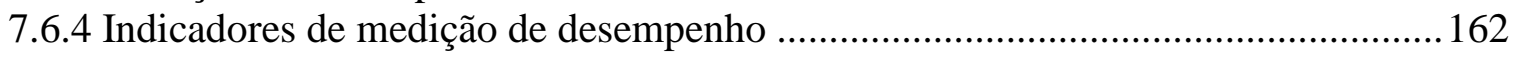

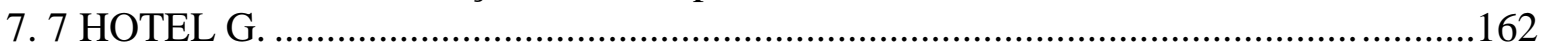

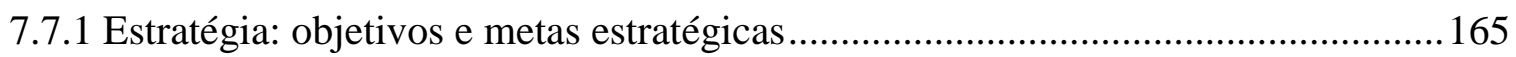

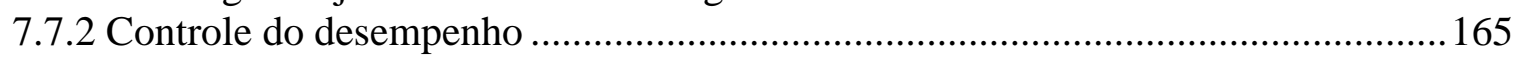

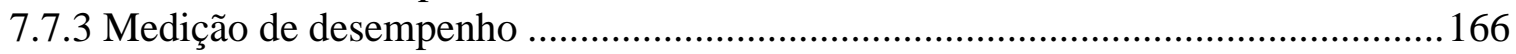

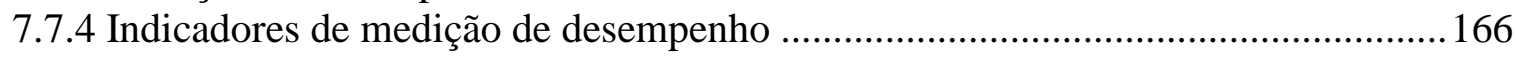

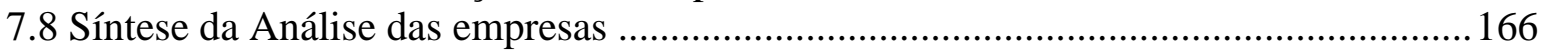

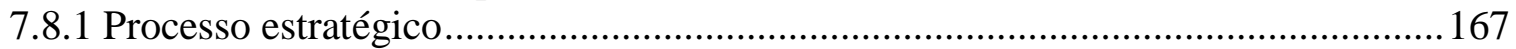

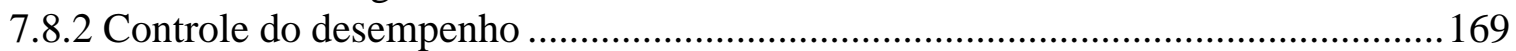

7.8.3 Indicadores de medição de desempenho ............................................................ 171

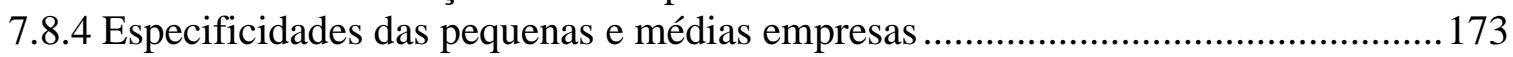

7.8.5 Síntese da análise por segmento hoteleiro........................................................ 175 
APÊNDICES

APÊNDICE A - CARACTERIZAÇÃO EMPRESA E DIRIGENTE

$\left(1^{\mathrm{a}}\right.$ e $2^{\mathrm{a}}$ FASES $)$

APÊNDICE B - OFÍCIO DE PESQUISA ( $2^{\mathrm{a}}$ Fase $)$

ROTEIRO DE ENTREVISTAS ( $3^{\text {a }}$ Fase)

APÊNDICE C - PROTOCOLO DE ESTUDO DE CASO ( $3^{\mathrm{a}}$ Fase $)$

APENNDICE D - LISTA DAS EMPRESAS MAPEADAS 


\section{INTRODUÇÃo}

Diante das adversidades impostas pelo mercado globalizado, com o aumento da competitividade e a busca crescente de melhores índices de eficiência, as organizações têm buscado permanentemente conceitos e ferramentas no campo da administração. As empresas vivem em um ambiente cada vez mais volúvel, tanto em relação à questão política e econômica, como em relação à evolução tecnológica e social e às barreiras mercadológicas, tornando sua continuidade mais difícil. As constantes mudanças no cenário organizacional fizeram com que as organizações mudassem nas últimas décadas, de uma produção em massa para o atendimento de mercados com clientes com necessidades diferenciadas em localidades diferentes e culturas diversas (FLEURY, 1995). Dessa forma, acentua-se não só a busca pela qualidade dos produtos e serviços, mas também nas necessidades e nos desejos dos clientes (MOTTA, 2003).

$\mathrm{Na}$ gestão estratégica atual, não é necessário gerenciar a empresa com um único objetivo, mas gerenciar o negócio da empresa, envolvendo fatores, recursos e variáveis externas e internas. O mercado atual exige que os gestores comportem-se e pensem estrategicamente, oferecendo promoções e flexibilidade nos serviços e até mesmo implantando programas de melhoria para gerar vantagens competitivas. É preciso uma compreensão melhor e um efetivo gerenciamento das atividades da empresa, envolvendo seu planejamento e controle. Dessa maneira, frente a um mercado consumidor cada vez mais exigente, crescem as atenções para com a melhoria organizacional, em como as empresas podem controlar seu desempenho, como medi-lo e avaliá-lo da melhor forma.

É necessário estar atento às novas tendências, aos concorrentes, ao comportamento e exigências dos clientes. De acordo com Kaplan (1998, p. 121):

[...] não se deve ficar acomodado com o desempenho atual, ainda que seja satisfatório. É importante que os executivos entendam que não serão superados pelos concorrentes se mudarem e aperfeiçoarem contínua e mais rapidamente do que eles. 
Historicamente, a medição de desempenho era vista como um mecanismo de controle, que assumia um papel repressor. No entanto, na gestão estratégica atual, a literatura aponta que a medição de desempenho extrapola o papel de controle. Assim, com ela, as organizações desenvolvem instrumentos que alimentem o processo de tomada de decisões, definindo o processo de gestão, avaliando sua eficácia e eficiência, assim como sua abrangência e consistência (SINK; TUTTLE, 1989).

\subsection{CARACTERIZAÇÃO DO TEMA DA PESQUISA}

O aumento da competição, dentro dos mais diversos mercados, tem feito com que as empresas se aprimorem tentando desenvolver um melhor desempenho dos métodos competitivos adotados a fim de que o gestor saiba o que pode ser feito para obter melhorias contínuas. Desse modo, torna-se necessário estabelecer ferramentas que ajudem os gestores a tomarem decisões oportunas e seguras em relação aos métodos adotados para conduzirem à organização da maneira mais eficiente. Um exemplo dessa carência é a inexistência de ferramentas para avaliar a evolução e o nível de sucesso das empresas.

Através de um efetivo controle gerencial, com base em ferramentas de desempenho, torna-se possível melhorar gradativamente o desempenho do desempenho, fazendo com que as organizações se mantenham competitivas. Desse modo, a empresa deve aperfeiçoar produtos, técnicas de venda, processos, etc., procurando adaptar sua estrutura organizacional a esta nova realidade de incertezas, que podem representar ameaças ou oportunidades (TERENCE, 2002, p.2).

A medição de desempenho é um processo de grande importância para a vida dos funcionários e futuro das organizações. Os relatórios e indicadores recebidos pela empresa demonstram como ela está e podem determinar o sucesso ou fracassos pessoais, profissionais ou organizacionais.

Buscar medir o desempenho em uma organização consiste essencialmente em melhorar a compreensão organizacional de sua realidade, quer dizer, está inserido no sentido de melhoria. É caracterizada por meio de diversas atividades e apresenta algumas finalidades como comunicar a estratégia e clarear valores; identificar problemas e oportunidades; melhorar o controle e planejamento; servir de base para um 
sistema de remuneração; favorecer o envolvimento de pessoas; entre outros. Sua operacionalização ocorre através de indicadores ou medidas de desempenho, aos quais buscam quantificar o desempenho do objeto de estudo.

Assim sendo, a medição de desempenho se faz cada vez mais necessária e importante para que seus gestores saibam como administrá-las e se despertem para atitudes estratégicas competitivas.

\subsection{FORMULAÇÃO DO PROBLEMA DE PESQUISA}

Embora a medição do desempenho organizacional seja uma preocupação relativamente antiga no mundo dos negócios, faltam modelos específicos para as pequenas e médias empresas hoteleiras. Apesar do grande número de sistemas de controle do desempenho organizacionais, não ocorre uma compreensão da razão ou da maneira pela qual os administradores devem utilizar esses sistemas para cumprir seus planos. A mensuração da satisfação com o desempenho apresentado pelas empresas pode ser considerada um dos indicadores de resultado do esforço gerado.

Já as pequenas e médias empresas hoteleiras são caracterizadas por algumas particularidades, tais como concorrência desigual, falta de recursos financeiros e tecnológicos, administração pouco especializada dos gestores, mão de obra desqualificada, entre outras. Mas, também, possuem grande flexibilidade e mantêm-se em contato direto com seus consumidores. Passam por constantes mudanças estratégicas e operacionais, de modo que entender tais alterações agrega valor ao conhecimento organizacional. Seu desempenho pode ser influenciado por essas particularidades, que determinam necessidades de mudança em sua gestão para que elas sobrevivam nesse contexto. Então, a questão é saber se as pequenas e médias empresas hoteleiras podem desenvolver bem indicadores de medição de desempenho, por serem tão complexos, e tais empresas terem tantas carências.

A exemplo de qualquer empresa, os pequenos e médios empreendimentos hoteleiros abrangem firmas de vários tamanhos, com variados graus de complexidade nas práticas da gerência, cujos gestores pouco conhecem sobre seu desempenho. No entanto, pouco se conhece de forma teórica e prática, sobre os indicadores de medição de desempenho dessas organizações.

Diante desse contexto, o problema da pesquisa resume-se na questão: 
As pequenas e médias empresas hoteleiras da região central do Estado de São Paulo realizam controle do desempenho; estabelecem indicadores e estes estão orientados para os fatores-chave do setor?

\subsection{DECLARAÇÃO DOS OBJETIVOS DA PESQUISA}

Toda e qualquer organização é constituída visando sempre o alcance de determinados objetivos, sejam eles sociais e/ou econômicos. Portanto, é necessário que a preocupação básica de qualquer administrador seja a de encontrar ferramentas de avaliação adequadas que permitam comparar o desempenho esperado e o alcançado pelas empresas. Em outras palavras, nenhuma organização pode deixar de avaliar os resultados alcançados, sob pena de desconhecer a verdadeira eficiência e eficácia das estratégias decididas.

O objetivo geral desta pesquisa é avaliar a existência de uma orientação do controle do desempenho utilizados nas pequenas e médias empresas hoteleiras e sua adequação aos fatores-chave de competitividade do setor. Essa pesquisa foi realizada na Região Central do Estado de São Paulo contemplando os Circuitos Paulista da Chapada Guarani e Ecocaipira, abrangendo as cidades de Águas de São Pedro, Analândia, Brotas, Charqueada, Corumbataí, Itirapina, Ipeúna, Piracaia, Rio Claro, Santa Cruz da Conceição, Santa Maria da Serra, São Carlos, São Pedro e Torrinha. Como objetivos específicos, pretende-se:

1) verificar a existência de uma orientação estratégica, particularmente voltada ao controle do desempenho: estabelecimento de objetivos e metas estratégicas;

2) verificar a existência do princípio e a prática do controle do desempenho e o estabelecimento de indicadores para a medição do desempenho organizacional;

3) analisar a influência das especificidades de gestão das pequenas e médias empresas no controle do desempenho;

4) identificar os indicadores de medição de desempenho das grandes empresas e discutir sua validade para as médias e pequenas organizações. 


\subsection{RELEVÂNCIA DA PESQUISA}

Estudar a prática e os indicadores de controle do desempenho utilizados pelas pequenas e médias empresas hoteleiras a partir de informações que fomentem o processo de gestão estratégica confere a este estudo o caráter de originalidade, o que justifica o desenvolvimento de um projeto de mestrado.

Tendo em vista os avanços tecnológicos, a quantidade de informações que surgem a cada dia e a sofisticação da concorrência, as empresas e os profissionais vêemse diante de uma constante exigência quanto ao seu aperfeiçoamento. Para isso, algumas medidas devem ser tomadas, como, por exemplo, a definição de indicadores de desempenho relevantes ao processo de controle da avaliação da gestão, que devem ser capazes de avaliar os resultados teóricos e práticos do processo (CARREGARO, 2003).

A pesquisa tem relevância tanto em sua dimensão teórica quanto no aspecto prático, pois no campo da estratégia empresarial a medição de desempenho fornece informações básicas para o controle e aprendizagem organizacional, tendo-se observado que nos últimos anos foi crescente o interesse sobre o assunto (MIRANDA et al., 1999).

A escolha do setor hoteleiro para a realização da pesquisa justifica-se pela ausência de dados concretos sobre gestão estratégica. Para essas empresas, torna-se mais difícil acontecerem mudanças na gestão, pois suas informações são ausentes ou insuficientes. Diante dessa lacuna, um estudo detalhado é essencial para aumentar a eficiência das empresas do setor (NUNES, 2003).

A opção pelas pequenas e médias empresas originou-se do fato de que são poucos os estudos referentes a elas, talvez por, muitas vezes, caracterizarem-se como empresas de gerenciamento menos complexo, isto é, com menor número de transações de negócios e número de participantes. No entanto, sua participação no mercado é crescente, fato que justifica a necessidade de conhecimento mais aprofundado sobre elas mesmas.

As pequenas e médias empresas integram estratos importantes da economia mundial, pois, além de produzirem parte do total de bens e serviços do país, também fornecem empregos, estimulam a competição e auxiliam as grandes empresas, promovendo o desenvolvimento econômico e social. Entretanto, a taxa de mortalidade das empresas desse porte é bastante alta.

Um estudo realizado no Serviço Brasileiro de Apoio às Micro e Pequenas Empresas de São Paulo - SEBRAE (2005) afirma que 56\% declararam falência até o 
quinto ano. A inquietação, na questão da mortalidade das pequenas e médias empresas, é que boa parte delas poderia ter sido salva se houvesse um planejamento antecipado, enfim, um pouco mais de conhecimento do mercado (MORRIS, 1991).

É indiscutível que as pequenas e médias empresas são relevantes no contexto socioeconômico brasileiro, funcionando como um grande amortecedor de crises. $\mathrm{Na}$ opinião de Andrade (2004, p.7), que pesquisou 77 pequenos hotéis nessa região:

[...] a contribuição das pequenas empresas hoteleiras da região de Brotas-SP é extremamente significativa na geração de emprego e renda para a população, principalmente pelo fato de a atividade turística ser economicamente importante para a região devido a suas características naturais e pela inexistência de outras atividades de expressividade na economia urbana local. Desse modo, torna-se cada vez mais necessário apoiar essas empresas de forma a potencializar a sua atuação, garantindo assim sua sobrevivência e participação na economia da região estudada.

Como as pequenas e médias empresas são importantes para o país, é fundamental contribuir para a construção de conceitos apropriados a elas e que venham ajudá-las a melhorar seu desempenho e sua competitividade, através de uma eficiente medição de desempenho para acompanharem e se adaptarem à nova realidade e às necessidades impostas pela globalização. Apesar de não existirem muitos dados disponíveis no Brasil sobre as PMEs hoteleiras, a sua importância é mais do que evidente em todos os setores da economia.

\subsection{ESTRUTURA DO TEXTO}

Este trabalho é dividido em 8 capítulos. O Capítulo 1, já apresentado, refere-se à concepção da pesquisa estabelecendo marcos fundamentais da investigação científica como a caracterização do tema, problema de pesquisa, objetivos da pesquisa e justificativa.

O Capítulo 2 descreve os diversos conceitos abordados de Estratégia o que dificulta uma definição de consenso e mostra que a estratégia determina a orientação geral e o foco da ação organizacional. Contempla também o Planejamento, seus papéis viáveis a desempenhar nas organizações e mostra que planejamento consiste em determinar as metas organizacionais e definir os meios para atingi-las. Ainda, apresenta o Planejamento Estratégico, uma ferramenta de trabalho que facilita as organizações a lidar com situações de mudanças, ou seja, é um importante instrumento de gestão. 
Aborda também a Aprendizagem na Organização e a Emersão da Estratégia, fruto do aprendizado organizacional.

O Capitulo 3 apresenta um panorama do Controle do Desempenho e uma revisão conceitual sobre as diferentes abordagens dada à Medição de Desempenho. Revela o vácuo existente entre a visão estratégica e visão operacional na gestão empresarial, ou seja, a falta de integração entre as diretrizes estratégicas e a operação das empresas. Mostra-se que o desempenho organizacional deve atuar como o desdobramento da estratégia. Apresenta também, um panorama geral dos Indicadores de Desempenho, a participação da Medição de Desempenho nas Pequenas e Médias Empresas. Considerando os modelos de medição de desempenho organizacionais, fazse a discussão sobre o Balanced Scorecard (BSC) por ser o mais difundido na literatura como um sistema de gestão estratégica, que comunica e alinha a estratégia para toda a empresa.

O Capitulo 4 descreve as Especificidades das Pequenas e Médias Empresas e elucida suas características peculiares e as principais dificuldades encontradas para sobreviver no mercado. Apresenta o grande número de variáveis que podem ser consideradas para classificar o porte das empresas, bem como sua relevância socioeconômica e a participação no mercado crescente. Também revela o uso da Medição de Desempenho na gestão das Pequenas e Médias Empresas e os seus benefícios.

O Capitulo 5 descreve o referencial sobre o Setor de Serviços, sua importância na economia mundial, bem como sua caracterização e prática administrativa. Descreve a questão do Turismo, uma indústria de serviços de fundamental importância para o desenvolvimento social e econômico de muitos países que contribui para a geração de empregos e, conseqüente, aumento do fluxo da circulação de riquezas, ocasionando uma elevação da renda per capita e geração de divisas. Contempla a Hotelaria, suas características e sua representatividade no setor de turismo, assim como apresenta as classificações existentes na literatura, os tipos de meios de hospedagem e a prática administrativa hoteleira. Por vez, revela a prática da medição de desempenho nas empresas hoteleiras e o uso de indicadores de desempenho nessas organizações.

O Capitulo 6, titulado como Trabalho de Campo, descreve os métodos de pesquisa utilizados, tipo de metodologia utilizada, apresentando suas características, as etapas e desenvolvimento. Também apresenta as questões e as variáveis de pesquisa, bem como descreve as técnicas de coletas de dados, a entrevista e o roteiro de entrevista propriamente dito. Com o objetivo de avaliar a coerência das relações estabelecidas 
entre as dimensões e decisões de encaminhamento de uma pesquisa, foi abordado o protocolo de estudo de caso e os aspectos éticos na pesquisa científica. Ainda, descreve as empresas estudadas, apresentando suas características, porte e organograma.

No final do texto da dissertação estão os capítulos: Apresentação e Análise de Dados (Capítulo 7) e as Considerações Finais (Capítulo 8). O capítulo 7 teve como propósito evidenciar as principais características levantadas com a pesquisa empírica, tendo por base os conceitos abordados na revisão teórica, apresentando a descrição prática sobre a estratégia organizacional, planejamento, controle, medição e o uso de indicadores de desempenho organizacional das pequenas e médias empresas. Já o capítulo 8 que se destina a resumir as principais conclusões do estudo bem como suas contribuições, limitações e implicações para pesquisas futuras. 


\section{ESTRATÉGIA, PLANEJAMENTO E OBJETIVO ESTRATÉGICO}

Este capítulo apresenta uma revisão conceitual sobre as diferentes abordagens dadas a estratégia, planejamento e planejamento estratégico, abordando, também as metodologias, implicações e a emersão da estratégia. Procura-se, aqui, fazer um levantamento da diversidade de definições presentes na literatura apresentando conceitos e práticas contemplados por vários autores que estudam o assunto.

Têm-se duas grandes visões neste capítulo: a estratégia planejada e a estratégia emergente. A estratégia planejada é considerada como uma ferramenta de trabalho que facilita a organização a lidar com situações de mudanças, e a emersão é considerada como fruto do aprendizado organizacional.

\subsection{CONCEITO DE ESTRATÉGIA}

A palavra estratégia vem do grego strategos, que quer dizer chefe do exército (FISCHMANN; ALMEIDA, 1991, p. 15). À primeira vista, parece tratar-se de um conceito estabilizado, de sentido único, de modo que, muitas vezes, entende-se ser desnecessária a sua definição. O termo estratégia teve várias fases e significados ao longo da história: evoluiu de um conjunto de ações e manobras militares para uma disciplina do conhecimento administrativo, a administração estratégica, conhecida tanto no ambiente empresarial quanto acadêmico (CAMARGOS; DIAS, 2003).

Durante muito tempo, a gestão da estratégia foi caracterizada como planejamento estratégico, e este como um instrumento de crescimento através da expansão e diversificação. Nesta perspectiva, criou-se uma sociedade de planejamento estratégico, de consultores, acadêmicos e autores. A estratégia vista como planejamento 
é difundida até os dias atuais tanto no meio acadêmico quanto no empresarial (TERENCE; BENZE; ESCRIVÃO FILHO, 2004).

A idéia de estratégia está intrinsecamente relacionada com a competição; ela é fator de diferenciação de uma empresa perante suas rivais; é o caminho que a organização deve seguir para sobreviver (SOBRAL; PECI, 2008). A estratégia conduz energias em uma determinada direção, ou seja, quanto mais articulada, mais profundamente se internaliza tanto nos hábitos organizacionais quanto nas mentes das pessoas (MINTZBERG, 2004). Pode ser caracterizada como "uma força mediadora entre a organização e seu ambiente" (MINTZBERG, 2003, p.25). Assim, pode-se considerar que a verdadeira estratégia está relacionada à ligação das decisões internas da empresa com os eventos externos para criar um novo e amplo consenso para ação entre todos os membros da organização: diretores, gerentes, supervisores e funcionários.

Para identificar as diferentes visões do processo estratégico e as atividades que dele fazem parte, é importante apresentar o conceito de estratégia, considerando-o tanto em sua evolução quanto na relação que tem com a competitividade e o desempenho organizacional. Thompson Jr., Strickland III e Gamble (2008, p.6) apresentam uma definição de estratégia:

[...] são as ações e os movimentos dos administradores no mercado a fim de aperfeiçoar o desempenho financeiro da empresa, reforçar sua posição competitiva no longo prazo e obter vantagem em relação aos concorrentes.

Ainda, Motta (2003) complementa que a estratégia consiste em um conjunto de proposições, redigidas de maneira sintética, normativa e direta, em como uma organização pretende atingir sua missão. Para o autor, as estratégias devem sempre reforçar a perspectiva global, diferentemente de decisões rotineiras.

De acordo com Porter (1999, p.63), estratégia significa "criar uma posição exclusiva e valiosa, envolvendo um diferente conjunto de atividades". Por sua vez, Thompson Jr. e Strickland III (2004, p.1) a contemplam como um conjunto de mudanças competitivas e abordagens comerciais nas quais os gerentes executam para atingir o melhor desempenho da empresa. Ainda, a estratégia é considerada como o "padrão ou plano que integra as principais metas, políticas e seqüências de ações de uma organização em um todo coerente" (QUINN, 2001, p.20). A estratégia define a 
natureza das contribuições que pretende oferecer a seus stakeholders ${ }^{1}$ (HAX; MAJLUF, 1988); está relacionada à ligação da organização ao seu ambiente, com a finalidade de estabelecer quais serão, por exemplo, os caminhos e os programas de ações que devem ser seguidos, a fim de que os objetivos das organizações sejam alcançados (OLIVEIRA, 2001; FISCHMANN; ALMEIDA, 1991). Assim, a estratégia determina a orientação geral e o foco da ação organizacional (QUINN, 2001, p.20).

Conforme apresentado, a estratégia é um conceito multidimensional e situacional, o que dificulta uma definição de consenso (HAMBRICK, 1980). Uma classificação amplamente divulgada na literatura sobre estratégia é a de Mintzberg, Ahlstrand e Lampel (2000). Os autores preferem conceituá-la através de cinco definições, também caracterizadas como 5 P: como plano, é a estratégia pretendida, olhar para frente, um guia ou curso de ação para o futuro e também referenciada como um esforço de impor à organização uma direção estável (MINTZBERG, 2004, p.196); padrão é a estratégia realizada, olhar o comportamento passado; posição, a localização de determinados produtos em determinados mercados, a estratégia olha para baixo (ponto em que o produto encontra o cliente) e para fora (para o mercado); perspectiva, maneira fundamental de uma organização fazer as coisas, a estratégia olha para dentro (da organização) e para cima (grande visão da empresa); e manobra ou truque, a estratégia é como uma manobra para enganar um oponente ou concorrente, isto é, uma ameaça. Dessa maneira, essas definições nos ajudam a compreender e a administrar os processos pelos quais se formam as estratégias

Outra grande diferença é destacar as dez escolas de pensamento de estratégia de Mintzberg, Ahlstrand e Lampel (2000) em "Safári de Estratégia", para evidenciar que não existe uma única definição de estratégia e para captar a visão de cada escola em relação ao seu processo: as três primeiras são prescritivas (a escola do design que surge na década de 60, a escola do planejamento que teve auge na década de 70 e a escola do posicionamento na década de 80). As próximas sete escolas que se preocupam como as estratégias são formuladas (a escola empreendedora, a escola cognitiva, a escola de aprendizado, a escola de poder, a escola cultural, a escola ambiental e a escola da configuração).

Os quadros 2.1 e 2.2 apresentam as dez escolas estratégicas e seus elementoschaves.

\footnotetext{
1 Stakeholders pode ser entendido como os clientes, empregados, fornecedores, acionistas e sociedade. (ATKINSON et al., 1997).
} 


\begin{tabular}{|c|c|c|c|c|c|}
\hline & Design & Planejamento & Posicionamento & Empreendedora & Cognitiva \\
\hline Estratégia & $\begin{array}{l}\text { Perspectiva } \\
\text { Planejada, } \\
\text { única }\end{array}$ & $\begin{array}{c}\text { Planos } \\
\text { decompostos } \\
\text { em sub- } \\
\text { estratégias e } \\
\text { programas }\end{array}$ & $\begin{array}{c}\text { Posições } \\
\text { genéricas } \\
\text { planejadas } \\
\text { (econômicas e } \\
\text { competitivas); } \\
\text { também } \\
\text { manobras }\end{array}$ & $\begin{array}{l}\text { Perspectiva } \\
\text { (visão) pessoal e } \\
\text { única como } \\
\text { nicho }\end{array}$ & $\begin{array}{l}\text { Perspectiva } \\
\text { mental } \\
\text { (conceito } \\
\text { individual) }\end{array}$ \\
\hline $\begin{array}{c}\text { Processo } \\
\text { Básico }\end{array}$ & $\begin{array}{l}\text { Simples e } \\
\text { Informal; } \\
\text { deliberado } \\
\text { (prescritivo) }\end{array}$ & $\begin{array}{c}\text { Formal, } \\
\text { deliberativo } \\
\text { (prescritivo) }\end{array}$ & $\begin{array}{l}\text { Analítico, } \\
\text { sistemático, } \\
\text { deliberado } \\
\text { (prescritivo) }\end{array}$ & $\begin{array}{c}\text { Visionário, } \\
\text { intuitivo, em } \\
\text { grande parte } \\
\text { deliberativo, } \\
\text { descritivo } \\
\end{array}$ & $\begin{array}{l}\text { Mental, } \\
\text { emergente } \\
\text { (dominante } \\
\text { ou forçado) }\end{array}$ \\
\hline $\begin{array}{l}\text { Mensagem } \\
\text { Pretendida }\end{array}$ & Adaptar-se & Formalizar & Analisar & Prever & $\begin{array}{c}\text { Lidar com o } \\
\text { assunto ou } \\
\text { criar }\end{array}$ \\
\hline $\begin{array}{c}\text { Mensagem } \\
\text { Atingida }\end{array}$ & Pensar & Programar & Calcular & Centralizar & $\begin{array}{l}\text { Preocupar- } \\
\text { se }\end{array}$ \\
\hline Mudança & Ocasional & Periódica & $\begin{array}{l}\text { Aos poucos, } \\
\text { freqüente }\end{array}$ & $\begin{array}{l}\text { Ocasional, } \\
\text { revolucionária }\end{array}$ & $\begin{array}{c}\text { Construída } \\
\text { mentalmente }\end{array}$ \\
\hline $\begin{array}{l}\text { Agente } \\
\text { Central }\end{array}$ & $\begin{array}{l}\text { Executivo } \\
\text { Principal }\end{array}$ & Planejadores & Analistas & Líder & Mente \\
\hline
\end{tabular}

Quadro 2.1: Elementos-Chave das Escolas do Design, Planejamento, Posicionamento, Empreendedora e Cognitiva

Fonte: Adaptado de Mintzberg, Ahlstrand e Lampel (2000)

\begin{tabular}{|c|c|c|c|c|c|}
\hline & Aprendizado & Poder & Cultural & Ambiental & Configuração \\
\hline Estratégia & $\begin{array}{l}\text { Padrões, } \\
\text { única }\end{array}$ & $\begin{array}{c}\text { Padrões e } \\
\text { posições } \\
\text { políticos e } \\
\text { cooperativos } \\
\end{array}$ & $\begin{array}{c}\text { Perspectiva, } \\
\text { coletiva e } \\
\text { única }\end{array}$ & Nichos & $\begin{array}{l}\text { Qualquer um à } \\
\text { esquerda }\end{array}$ \\
\hline $\begin{array}{c}\text { Processo } \\
\text { Básico }\end{array}$ & $\begin{array}{l}\text { Emergente, } \\
\text { informal, } \\
\text { confuso } \\
\text { (descritivo) }\end{array}$ & $\begin{array}{l}\text { Conflitivo, } \\
\text { agressivo, } \\
\text { confuso } \\
\text { (descritivo) }\end{array}$ & $\begin{array}{c}\text { Ideológico, } \\
\text { forçado, } \\
\text { coletivo, } \\
\text { deliberado } \\
\text { (descritivo) }\end{array}$ & $\begin{array}{l}\text { Passivo, } \\
\text { imposto e } \\
\text { emergente } \\
\text { (descritivo) }\end{array}$ & $\begin{array}{c}\text { Interativo, } \\
\text { episódico, } \\
\text { (descritivo e } \\
\text { prescritivo) }\end{array}$ \\
\hline $\begin{array}{l}\text { Mensagem } \\
\text { Pretendida }\end{array}$ & Aprender & Promover & $\begin{array}{l}\text { Coadunar- } \\
\text { se }\end{array}$ & Reagir & $\begin{array}{c}\text { Transformar, } \\
\text { Integrar }\end{array}$ \\
\hline $\begin{array}{l}\text { Mensagem } \\
\text { Atingida }\end{array}$ & Jogar & Reunir & Perpetuar & Capitular & Encurvar-se \\
\hline Mudança & $\begin{array}{l}\text { Contínua, } \\
\text { incremental }\end{array}$ & $\begin{array}{c}\text { Freqüente, } \\
\text { pouco a } \\
\text { pouco }\end{array}$ & $\begin{array}{l}\text { Infreqüente } \\
\text { (enfrenta } \\
\text { resistência } \\
\text { ideológica) } \\
\end{array}$ & Rara & $\begin{array}{c}\text { Ocasional e } \\
\text { revolucionária } \\
\text { (outras vezes } \\
\text { incremental) }\end{array}$ \\
\hline $\begin{array}{l}\text { Agente } \\
\text { Central }\end{array}$ & Aprendizes & $\begin{array}{l}\text { Qualquer um } \\
\text { com poder, } \\
\text { toda } \\
\text { organização } \\
\end{array}$ & $\begin{array}{c}\text { Coletividad } \\
\text { e }\end{array}$ & Ambiental & $\begin{array}{c}\text { Especialmente } \\
\text { o principal } \\
\text { executivo }\end{array}$ \\
\hline
\end{tabular}

Quadro 2.2: Elementos-Chave das Escolas do Aprendizado, Poder, Cultural, Ambiental e Configuração

Fonte: Adaptado de Mintzberg, Ahlstrand e Lampel (2000) 
A seguir apresenta-se uma breve descrição das dez escolas de pensamento estratégico (MINTZBERG; AHLSTRAND; LAMPEL, 2000):

- Escola de Design: enfatiza a formulação estratégica como um processo de concepção. Representa a visão mais influente do processo de formação estratégica, buscando atingir uma adequação entre as capacidades interna e externa. A estratégia resulta em um projeto com caráter de formação prescritivo.

- Escola do Planejamento: destaca a formulação estratégica como um processo formal, estruturado e numérico seguido de várias etapas, necessariamente de concepção. Dessa maneira, a estratégia resulta em um plano com caráter de formação prescritivo.

- Escola do Posicionamento: considera a seleção de posições estratégicas no mercado mediante um processo analítico de decisão. Esta escola é menos preocupada com a formulação estratégica do que com o conteúdo real delas. A estratégia resulta em uma posição com caráter de formação prescritivo.

- Escola Empreendedora: enfatiza a formulação estratégica como um processo visionário que aponta o papel dos líderes carismáticos e dos empreendedores visionários. A estratégia representa uma visão com caráter de formação descritivo.

- Escola Cognitiva: presume a formulação estratégica como um processo mental de formulação e implementação de estratégias. Busca usar as mensagens da psicologia cognitiva para influenciar o estrategista. A estratégia resulta em um processo mental descritivo.

- Escola de Aprendizado: propõe a formulação estratégica como um processo emergente com ênfase no resultado através de tentativas e erros. A estratégia caminha em passos curtos à medida que a organização se adapta ou aprende. O processo da estratégia tem caráter de formação descritiva.

- Escola do Poder: revela a formulação estratégica como um processo de negociação e interesses, ou seja, por grupos conflitantes ou pelas próprias organizações na elaboração das estratégias. Assim, o processo da estratégia tem caráter descritivo.

- Escola Cultural: desvenda a formulação estratégica como um processo coletivo, de inserção humana e social. A formulação da estratégia está enraizada na cultura organizacional por ser um processo social e integrativo. $\mathrm{O}$ seu processo apresenta-se com caráter descritivo. 
- Escola Ambiental: trata a formulação estratégica como um processo reativo em que a iniciativa está no contexto externo da organização e não dentro dela. $\mathrm{O}$ ambiente é que determina a estratégia organizacional. O processo da estratégia tem caráter descritivo.

- Escola da Configuração: representa uma síntese das escolas anteriores, enfatizando a formulação da estratégia como um processo de transformação. Contempla grande parte da literatura e da prática prescritiva das mudanças estratégicas. O processo da estratégia apresenta-se com caráter descritivo e prescritivo.

Além das dez escolas, pode-se considerar a estratégia dividindo-a em duas vertentes: uma deliberada, baseada em planos preelaborados ou fixados, as intenções são plenamente realizadas, e outra emergente - um padrão realizado que não era expressamente pretendido -, construído por meio de ações, dos atores organizacionais ou das forças do ambiente. Segundo Escrivão Filho (2006), o estudo das escolas de pensamento de estratégia possui uma enorme diversidade e vários estudiosos da área só se interessam por parte do conhecimento. Como exposto no livro "Safári de Estratégia" de Mintzberg; Ahlstrand; Lampel (2000), as pessoas têm limites de enxergar o todo, enxergam uma ou outra parte; é preciso ver a estratégia por inteiro. Além disso, Müller (2003) esclarece que todo processo de estratégia precisa combinar com vários aspectos das diferentes escolas como sociais, demandas do ambiente, liderança, forças da organização, concessões entre o incremental e o revolucionário. Todos os aspectos precisam estar presentes em maior ou menor grau no processo, mesclando formas realistas, deliberadas e emergentes de estratégia.

É importante ressaltar que as estratégias existem em vários níveis em qualquer organização, desde o nível estratégico - diretoria, até os níveis operacionais departamentais (QUINN, 2001). A estratégia organizacional ocorre em três níveis: corporativa, que estabelece em qual setor a empresa deve operar; unidade de negócios, que estabelece a maneira de competir no setor ou negócio escolhido; e funcional, que estabelece a maneira que uma área funcional deve trabalhar a partir da estratégia de negócio escolhida (CAMARGOS; DIAS, 2003). Nos níveis hierárquicos mais altos das organizações (nível estratégico/corporativo), o executivo é como um "capitão de um navio", que elabora e implementa as estratégias organizacionais, que orienta as tarefas de formulação e implementação de um planejamento estratégico para toda a organização. As opiniões e conclusões desses executivos em relação à direção e ao foco do futuro (produto/mercado/cliente/tecnologia) constituem a visão estratégia da 
organização, ou seja, alinha a organização para uma determinada direção, indicando a trajetória estratégica e moldando a identidade organizacional. Ainda, a identificação de uma estratégia presume a realização de pesquisas de informações sobre as ações organizacionais no mercado e seus métodos competitivos (THOMPSON Jr.; STRICKLAND III; GAMBLE, 2008).

Confirma-se, assim, que o termo estratégia é algo relativamente complexo, não havendo consenso sobre a questão. Apesar de não haver um consenso, registram-se alguns elementos comuns, como a elaboração de metas, decisões e o estabelecimento de uma trajetória de ação para atingir objetivos predeterminados, visando o aumento da vantagem competitiva. As estratégias estão associadas com a palavra como: como crescer no negócio, como vencer a concorrência, como satisfazer os clientes, como responder as variáveis do mercado, entre outros. Ela é específica em cada empresa, adaptada para a situação própria da empresa e seus objetivos de desempenho (THOMPSON JR.; STRICKLAND III, 2004).

\subsection{PLANEJAMENTO NA ORGANIZAÇÃO}

Planejar pode ser entendido como "tomar decisões sobre o futuro" (MAXIMIANO, 2004, p.137); é "decidir antecipadamente o que deve ser feito, ou seja, o plano é uma linha de ação preestabelecida" (MIRANDA, 1980, p.203). O planejamento é uma forma de aprendizado; é com ele que se aprende sobre as demandas e necessidades externas (MOTTA, 2003). Muitas pessoas conceituam o planejamento como pensar no futuro, outras o conceituam como controlar o futuro, um projeto de um futuro desejado. Outras expressam o planejamento como tomada de decisão. Na visão como um processo, o planejamento pode se entendido como tomada de decisão integrada. Ainda, é um procedimento formal para alcançar um resultado articulado na forma de um sistema integrado de decisões, ou seja, é um conjunto de conceitos e procedimentos (MINTZBERG, 2004, p. 22-27). O planejamento só passa a existir quando uma empresa, grupo ou comunidade passa a almejar uma situação desejada (VASCONCELLOS FILHO, 1985).

Segundo Sobral e Peci (2008, p.7-8) o planejamento consiste: 
[...] na especificação dos objetivos a serem atingidos, na definição das estratégias e ações que permitam alcançá-los, e no desenvolvimento de planos que integrem e coordenem as atividades da organização. [...] permite que os administradores e trabalhadores tenham sua ação orientada para determinados objetivos, permitindo-lhes concentrar sua atenção no que é mais importante para a organização.

Ainda, para os autores, o planejamento tem a dupla atribuição de definir " $o$ que deve ser feito" (os objetivos) e "como deve ser feito" (os planos), conforme a figura 2.1.

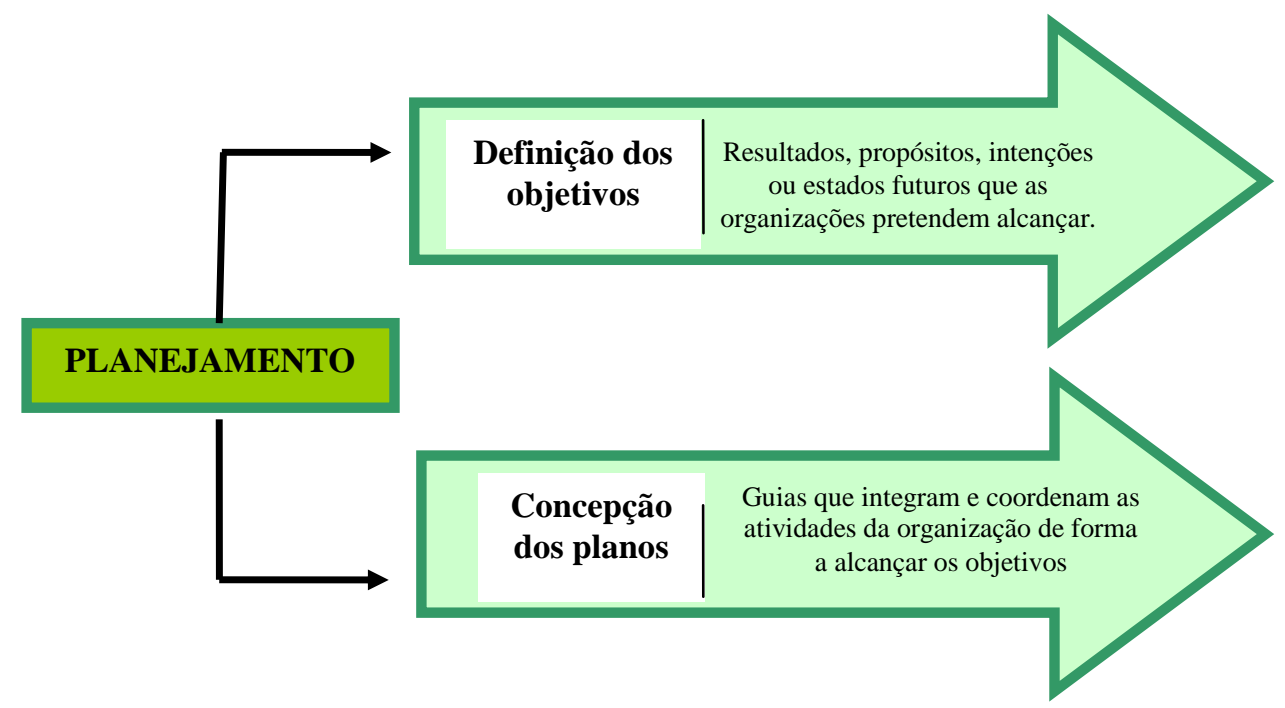

Figura 2.1: A Dupla Atribuição do Planejamento

Fonte: Sobral e Peci (2008)

Para muitas empresas o planejamento funciona como um "amortecedor" para impactos de uma crise instalada (VASCONCELLOS, 1985, p.75); previne um desempenho fraco (HARRINGTON, 1993); assegura que o futuro organizacional seja levado em consideração; o planejamento é visto como uma forma superior de administração e formaliza a estratégia (MINTZBERG, 2004). Ainda, o planejamento é considerado estratégico a partir do momento em que se tem como principal característica a ênfase no ambiente organizacional (VASCONCELLOS, 1985; MINTZBERG, 2004).

Talvez o tema mais visto na literatura de planejamento esteja relacionado ao controle de estratégias e decisões, de pensamentos e ações, do presente e futuro, de mercados e clientes, de funcionários e gerentes (MINTZBERG, 2004). O planejamento caracterizado com o enfoque de controle estimula a participação e facilita o consenso. 
Desse modo, o planejamento destina-se a controlar outros na organização (aqueles cujo trabalho é coordenado) (MINTZBERG, 2004).

$\mathrm{O}$ ambiente muda a todo instante, exigindo que as organizações adotem um postura estratégica ao contexto em que está inserida. Para Maximiano (2004, p.138) o processo de planejamento pode ser definido como:

- objetivos e resultados a serem alcançados;

- meios para a realização de resultados almejados;

- uma situação conhecida para uma situação desejada;

- construção de uma nova visão, de uma situação nova;

- definição e avaliação de um objetivo e escolha de uma direção de ação.

É importante destacar que a articulação dos planos (por meio de planejamento) na organização é essencial, pois fornece um mecanismo de comunicação promovendo a coordenação entre as partes da organização (MINTZBERG, 2004). Ele é o registro das decisões, o guia para a ação no futuro (MAXIMIANO, 2004). Dependendo de sua abrangência, os planos podem ser classificados em três níveis: estratégico, funcional e operacional.

Considerando os níveis e planos organizacionais, a figura 2.2 contempla o processo de planejamento que se inicia com a definição da missão formal (finalidade básica da organização) que é a base para o nível estratégico (empresarial) de metas e planos que molda o nível tático (divisional) e o nível operacional (departamental).

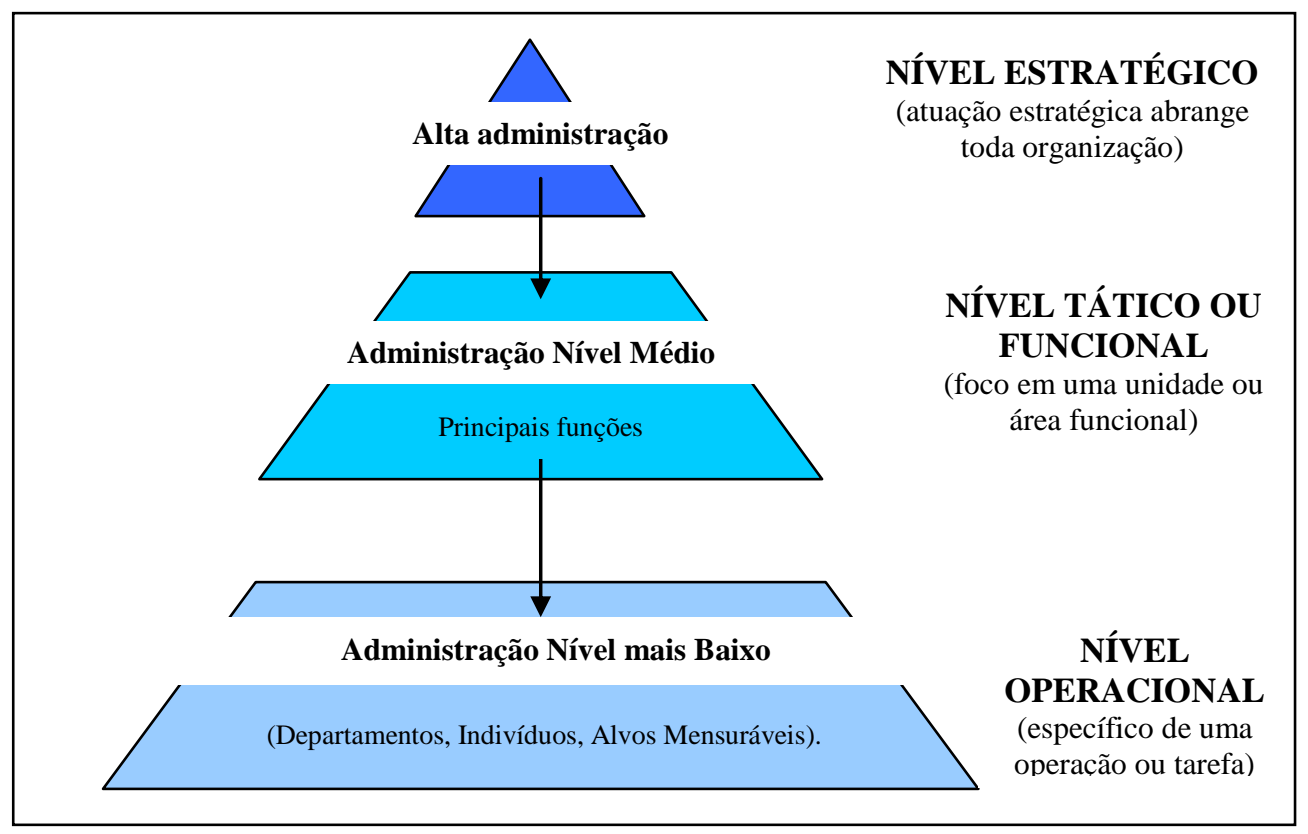

Figura 2.2: Níveis Hierárquicos 


\subsection{ESTRATÉGIA PLANEJADA}

O final da década de 1950 e início da década de 1960 foi um período de novos desafios e incertezas para as empresas. A mudança do conceito de planejamento para um conceito mais amplo de planejamento estratégico foi apresentado por Porter através da ideia de vantagem competitiva, resultante de um desequilíbrio no mercado e que seria o objetivo final de toda a empresa (PORTER, 1985). O planejamento estratégico é um processo de determinação dos principais objetivos da organização, das políticas e estratégias que a conduzirão, do uso e disponibilização dos recursos para a realização dos objetivos, sendo esse processo composto por premissas, planejamento, revisão e implementação. Ou seja, "é o processo de desenvolver a estratégia” (HAMPTON, 1992, p.198). Desse modo, "a formação de estratégia é um processo de planejamento, idealizado ou sustentado por planejadores para planejar a fim de produzir planos" (MINTZBERG, 2004, p.41).

O processo de planejamento estratégico, de acordo com Oliveira (2001, p.90), apresenta os seguintes passos:

- Passo 1- definição da visão da empresa, identificando os limites que os principais responsáveis pela organização conseguem enxergar;

- Passo 2- estabelecimento das expectativas dos acionistas, conselheiros e da alta administração;

- Passo 3- realização da análise externa do ambiente, ou seja, as ameaças e oportunidades bem como as melhores práticas para evitar ou utilizar dessas situações;

- Passo 4- análise do ambiente interno, pela qual identificam e analisam os pontos fortes, fracos e neutros da organização;

- Passo 5- análise dos concorrentes, considerando um detalhamento de um aspecto da análise externa da empresa. Vale considerar que a análise dos concorrentes deve ser bem efetuada, pois proporcionará a identificação de vantagens da própria organização e de seus concorrentes;

- Passo 6- estabelecimento da missão ou a razão de ser da empresa, assim como seu posicionamento estratégico, ou seja, “onde a empresa quer ir" e sua "razão de ser";

- Passo 7- identificação dos propósitos atuais e potenciais da organização; 
- Passo 8- estruturação e debate de cenários, pelos quais o executivo desenvolve cenários (primeiro passo do processo de planejamento estratégico) que retratem determinado momento no futuro ou a evolução e sequência de eventos. Por vez, verifica o posicionamento da organização diante de seu ambiente quanto à sua capacidade de aproveitar oportunidades e ameaças;

- Passo 9- estabelecimento das macroestratégias, ou seja, as ações e caminhos organizacionais para melhor interagir, usufruir e gerar de vantagens competitivas;

- Passo 10- definição das macropolíticas (orientações que servem de base de sustentação para as principais decisões) e os resultados a serem alcançados;

- Passo 11- estabelecimento de estratégias (ações e caminhos mais adequados para alcançar os objetivos e desafios organizacionais;

- Passo 12- estabelecimento de políticas, como a definição dos níveis de delegação, consecução de metas, desafios e objetivos da organização (OLIVEIRA, 2001, p.90).

Num processo de formulação de planejamento estratégico, a missão pode ser definida como sua função principal, deixando claro por que a organização existe e determina seu negócio (CHIAVENATO, 2000). Outra grande diferença que precisa ser considerada no estudo do planejamento estratégico é que, mais do que planejar, o dirigente precisar agir estrategicamente. $\mathrm{O}$ processo de planejamento precisa se completar com a implementação de mudanças organizacionais estratégicas para a organização navegar com direção e flexibilidade (VASCONCELLOS, 1895).

O planejamento estratégico contempla o conhecimento de suas potencialidades, dificuldades e o comportamento das forças ambientais bem como sua influência positiva ou negativa no futuro organizacional. Assim, o produto desse pensamento sistematizado é o que possibilita a alta administração decidir o rumo de toda organização, ou seja, sua estratégia, como exemplo, a penetração em novos mercados, o caminho para a inovação, a integração horizontal de produtos, entre outros (ALBUQUERQUE, 2004). O planejamento estratégico é um instrumento administrativo que dá direção à organização; estabelece a missão e estratégias da organização, para declaração dos objetivos organizacionais e para prover as bases a partir das quais o desempenho global da companhia pode ser controlado e medido (SHARDER et al., 1989). Ainda, o planejamento estratégico cria a consciência de ameaças e oportunidades, de pontos fortes e fracos para o cumprimento dos objetivos, conduzindo a organização na escolha 
e construção de seu futuro (FISCHMANN; ALMEIDA, 1991; VASCONCELOS FILHO; PAGNONCELLI, 2001).

O planejamento estratégico também é considerado como o processo de definir os objetivos e a missão organizacionais e as maneiras de atingi-lo; estabelece os produtos e serviços oferecidos pela organização, os mercados, clientes e maneiras de lidar com os concorrentes (MAXIMIANO, 2004). É um sistema de levantamento e avaliação de situações, integrado de decisões, que produz dados e informações. Ajuda os gestores a pensar estrategicamente e apoiar a articulação de estratégias ou visões de futuro na organização (VASCONCELLOS, 1985; MINTZBERG, 1994; ANSOFF, DECLERK e HAYES, 1981). Ele é essencial à sobrevivência da empresa, podendo contribuir também positivamente para o desempenho de uma empresa (PHILLIPS, 1996).

Ainda, o planejamento estratégico pode ser visto como uma atividade gerencial que ajuda os executivos estabelecerem um rumo para a organização no relacionamento entre a organização e o ambiente, correspondendo a um conjunto de providências a serem tomadas pelos gestores, em que o futuro possa ser diferente do passado (OLIVEIRA, 1999; MAXIMIANO, 2004). Proporciona uma visão do futuro para a organização, aumentando as chances de a empresa aproveitar as oportunidades, empregar melhor os seus recursos e explorar suas potencialidades (TIFFANY; PETERSON, 1999).

As definições sobre planejamento estratégico apresentadas por diversos autores acrescentam elementos importantes à nossa compreensão, como: bom planejamento contribui para o sucesso (BRANCH, 1991; HILLIDGE, 1990); planejamento afeta o nível do desempenho (SCHEWECK; SHRARDER, 1993); o resultado do desempenho poderá ser baseado em três domínios: financeiro, domínio financeiro e operacional e domínio da efetividade organizacional (VENKATRAMAN; RAMANUJAM, 1986). Para Ansoff e McDonnell (1984), Porter (1991) e Fechio (2001), o dinamismo e a interação dos planos de ações que programam o planejamento estratégico possibilitam a implantação da chamada gestão estratégica.

Entretanto, existem na literatura muitas críticas à utilização do planejamento estratégico (MINTZBERG, 2004; MEGGINSON et al., 1986; VASCONCELLOS, 1985; FISCHMANN; ALMEIDA, 1991; ANSOFF, 1993). De acordo com Fischmann (1987), o problema principal do planejamento estratégico é a instabilidade existente entre a excessiva atenção de estratégias dada à formulação e a precariedade que cerca a 
implementação que ainda está no começo. Pode apresentar algumas desvantagens para a organização como as de restringir a inovação da administração e o exercício da iniciativa (MEGGINSON et al., 1986).

Segundo Ansoff (1993, p. 58), “a resultante do planejamento estratégico é apenas um conjunto de planos e intenções. Por si só, o planejamento estratégico não produz ações, nem mudanças viáveis na empresa". Dessa maneira, como principais obstáculos ao planejamento estratégico têm-se: o desconhecimento das técnicas, falta de tempo e perda de autonomia (FISCHMANN; ALMEIDA, 1991). Ainda, de forma geral, Terence (2002, p.24) apresenta: a dificuldade na previsão do futuro, o excesso de burocratização provocado pelo processo, a dificuldade de implementação, e o fato de não representar um pensamento estratégico para a organização.

Conclui-se, assim, que o verdadeiro propósito do planejamento estratégico é proporcionar o desenvolvimento do pensamento estratégico (HERACLEOUS, 1998).

\subsection{OBJETIVOS E METAS ESTRATÉGICAS}

Um objetivo organizacional pode ser considerado como os alvos de desempenho que uma organização pretende alcançar; funcionam como referência para medir o desempenho (Thompson, Strickland e Gamble, 2008); ao passo que, para Certo e Peter (2005), ele é considerado um alvo para o qual a organização direciona seus esforços. É importante considerar que muitos teóricos indicam o termo "objetivo" e outros sugerem "meta" como sinônimos, enquanto para outros esses termos significam conceitos diferentes.

Fixar objetivos organizacionais consiste em converter a visão estratégica em metas de desempenho específicas, ou seja, resultados e conseqüências que se deseja obter. Em geral, os objetivos representam um compromisso para se obter determinados resultados e consequências e, quando bem formulados, são quantificáveis ou mensuráveis compostos por uma data-limite para cumprimento (THOMPSON; STRICKLAND; GAMBLE, 2008). Ainda, para os autores, os objetivos são valiosos porque atuam como referência de acompanhamento do desempenho e progresso de uma organização, a qual a organização cumpre suas metas de atuação e geralmente obtém 
um melhor desempenho do que outra que deixa de se preocupar com o cumprimento de seus objetivos.

Os objetivos fornecem o fundamento para o planejamento, para a organização, para a motivação e para o controle; sem objetivos, a organização fica sem rumo. Para Certo e Peter (2005), fixar objetivos é usá-los como:

- diretrizes na tomada de decisão;

- guia para aumentar a eficiência organizacional;

- guia para avaliação do desempenho.

Cabe destacar a visão de Thompson, Strickland e Gamble (2008, p.29) da importância dos objetivos de uma organização:

"as experiências de inúmeras empresas e gerentes ensinam que especificar precisamente quanto, que tipo de resultado, em que ocasião e então avançar com ações e incentivos calculados para ajudar a cumprir os resultados almejados melhora o desempenho efetivo".

Os gerentes devem usar o exercício de determinação de objetivos como uma ferramenta que impulsiona a organização a desempenhar seu pleno potencial e produzir os melhores resultados possíveis. Dessa maneira, incentivam o desempenho excepcional e evitam o conformismo de ganhos modestos (THOMPSON; STRICKLAND; GAMBLE, 2008).

Thompson, Strickland e Gamble (2008) apresentam dois tipos de objetivos adotados comumente nas organizações: os financeiros e os estratégicos. Os objetivos financeiros relacionam-se às metas de desempenho financeiro estabelecidas como aumento anual de $\mathrm{x} \%$ das receitas anuais, maiores margens de lucros, excelente classificação para pedido de crédito e para emissão de dívida e lucros estáveis durante períodos de recessão. Já os objetivos estratégicos relacionam-se aos resultados das metas que indicam se uma empresa está consolidando sua posição no mercado e suas perspectivas de negócios futuros, como obter uma participação de mercado $\mathrm{x} \%$, ter custos menores que dos rivais, conquistar a liderança tecnológica, reforçar o apelo à marca, ter vendas maiores que as dos concorrentes e lançar continuamente produtos ou serviços antes dos concorrentes.

De maneira diferente, Certo e Peter (2005) apresentam os dois tipos de objetivos mais adotados nas organizações: os de curto prazo (metas a alcançar no período de um a dois anos) e os de longo prazo (metas a alcançar no período entre três a cinco anos). Para os autores, esses dois tipos diferem-se no período de tempo que se 
leva para alcançar os objetivos e em relação ao grau de especificidade, pois os objetivos de curto prazo são mais específicos acerca das questões a serem executadas, quando e em que área organizacional.

De acordo com Drucker ${ }^{2}$ (apud Certo e Peter, 2005, p.55-56), as organizações devem planejar o estabelecimento de diversos objetivos ao invés de um só. Assim, o autor apresenta oito áreas-chave que devem ser abordadas pelos objetivos organizacionais:

- posicionamento de mercado (onde a organização se encontra em relação a seus concorrentes);

- inovação (os objetivos devem indicar as metas que a organização almeja em termos de inovação);

- produtividade (as organizações que usam menos recursos para produzir uma quantidade específica de produtos, e que portanto, são mais produtivas);

- níveis de recursos (a organização deve especificar objetivos que indiquem as quantidades relativas de cada ativo que deve ser mantido);

- lucratividade (indica o nível de lucratividade desejada);

- desempenho e desenvolvimento do administrador (é importante enfatizá-los para o sucesso da organização, estabelecendo os objetivos organizacionais a eles relacionados e esforçando-se para alcançá-los);

- desempenho e atitude do funcionário;

- responsabilidade social (ajudar a melhorar o bem-estar social da sociedade e esforçar-se para alcançar os objetivos organizacionais).

Desenvolver a visão e missão estratégicas, fixar objetivos e criar uma estratégia determinam a direção que a organização deve seguir; mapeiam para onde a organização se dirige, os resultados estratégicos e financeiros almejados, as medidas competitivas e as ações internas para o atingimento dos resultados desejados. Juntos, constituem o plano estratégico, que detalha a orientação futura, as metas de desempenho e a estratégia organizacional (THOMPSON; STRICKLAND; GAMBLE, 2008).

Conclui-se que a determinação de objetivos não deve se limitar unicamente aos altos executivos; os objetivos precisam ser desdobrados em todos os níveis organizacionais para que cada unidade fixe e almeje alvos que contribuam diretamente para resultados almejados. Assim, fixar objetivos deve ocorrer de cima para baixo, com

\footnotetext{
${ }^{2}$ DRUCKER, P. The practice of management. Nova York: Harper \& Row, 1954.
} 
vistas ao cumprimento de objetivos estratégicos e financeiros para toda organização, no sentido da aprovação e comprometimento da alta direção; mas a participação dos gerentes, supervisores e funcionários é essencial para que o planejado seja realizado com sucesso.

\subsection{ESTRATÉGIA EMERGENTE}

Embora seja um tema amplamente discutido, pouco conhecimento se tem sobre o modo como a estratégia emerge e sobre seus benefícios. As críticas ao planejamento estratégico geraram outras formas de ver a estratégia. Em torno da ideia de estratégia não planejada, diferentes autores abordaram o fenômeno da emersão a partir de perspectivas diversas. Eles respondem de diferentes maneiras à pergunta: "Como é que uma estratégia emerge?".

O termo "estratégia emergente" foi introduzido na década de 70 por Henry Mintzberg (1978). A noção dominante na época era a de que a estratégia é um plano explícito, formulado pelos dirigentes da organização, que estabelecem objetivos e programas de ação detalhados. Entretanto, Mintzberg (1978) descobriu que as ações estratégicas se formavam até mesmo na ausência de um plano. Por essa razão, a estratégia passou a ser vista não em termos de intenções como em um plano, mas sim em termos do que a organização efetivamente faz (MINTZBERG, 1978; MINTZBERG, AHLSTRAND e LAMPEL, 2000).

As estratégias emergentes especificam as que não são planejadas, mas formadas por ações resultantes das atividades diárias de negócios, como da relação entre a empresa, seus clientes e o mercado. As emergentes representam o filtro entre o planejamento formal e os caminhos a serem percorridos no curto prazo e são fundamentais para as de longo prazo (BORGES JÚNIOR; LUCE, 2000). As estratégias emergentes identificam-se como tais à medida que vão se estendendo ou até mesmo depois que ocorrem (MARIOTTO, 2003). Dessa forma, caracterizam-se como um padrão estabelecido por uma sucessão de ações não determinadas anteriormente (MINTZBERG, 1978; MINTZBERG; WATERS, 1985).

Uma estratégia emergente é, essencialmente, uma "estratégia não planejada". Provém principalmente de situações operacionais do cotidiano, ao invés de análises e métodos formais. Quinn (2001) estabeleceu o termo "formação de estratégia" referente 
ao processo pelo qual as estratégias são criadas, seja ele o de planejamento consciente e explícito, ou seja um processo emergente. Por vez, para o autor a estratégia é um padrão em uma sucessão de decisões, que permite a um observador examinar o comportamento da organização e que, ao reconhecer um padrão em suas ações, conceitue a estratégia, mesmo que a organização não tenha descrito tais ações previamente em um plano.

É importante destacar que as formas como as estratégias surgem e se implementam não é um processo idêntico em todas as organizações. Resulta inicialmente de uma conjugação de fatores externos como características e condições do meio envolvente e de condições internas como dimensão, capacidades materiais e humanas, organizacionais, que condicionam cada situação particular. As estratégias emergem quando pessoas, individualmente ou coletivamente, aprendem com uma determinada situação assim como a capacidade da sua organização lidar com ela (MINTZBERG; AHLSTRAND; LAMPEL, 2000). Ainda, Prado Júnior (2003) complementa que o processo de formação da estratégia emergente ocorre mediante dois processos: mecanismos ajustáveis e controle mútuo; por mecanismos organizacionais de seleção de iniciativas e de priorização de projetos, os quais emergem do relacionamento entre a gerência média e a alta gestão. Abaixo, é apresentado o processo de formação da estratégia emergente (figura 2.3).

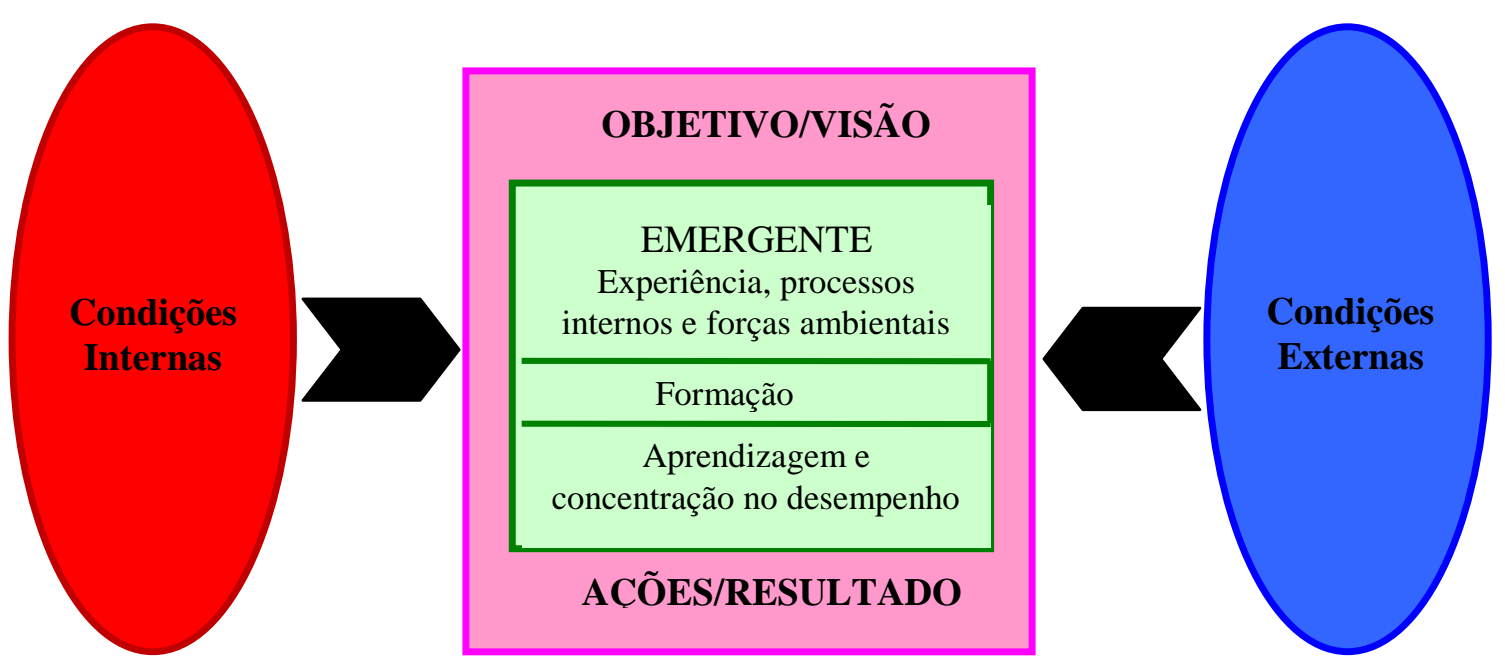

Figura 2.3: Processo Emergente

Fonte: Terence (2008, p.53) 
Convém destacar que toda formação de estratégias ocorre em dois aspectos: um deliberado e outro emergente. As estratégias emergentes e deliberadas coexistem constantemente, em maior ou menor grau, no processo de criação de estratégias de qualquer organização. A perspectiva da estratégia como deliberação caracteriza-se por intencionalidade e planejamento antecipado: a empresa prevê os acontecimentos do meio ambiente e desenvolve um plano de ação para responder aos eventos de forma a maximizar os seus resultados; e estratégia como processo dinâmico e emergente, que se caracteriza por interações entre os agentes presentes no cotidiano das organizações, emerge da organização em resposta a uma oportunidade do ambiente (REBELO; ERDMANN, 2004; BORGES JÚNIOR; LUCE, 2000). As estratégias deliberadas estão relacionadas às tentativas de controlar todos os aspectos da organização; é inerente às Escolas Prescritivas de Administração Estratégica (Escolas de Design, Planejamento e Posicionamento), que enfatizam o controle em detrimento do aprendizado no processo (REBELO; ERDMANN, 2004).

Para Mintzberg, Ahlstrand e Lampel (2000, p.18) “as organizações desenvolvem planos para o futuro e também extraem padrões de seu passado". Pode-se chamar uma de estratégia pretendida e outra de realizada, conforme a figura 2.4. Assim, a estratégia emergente pode ser considerada como um padrão que não era expressamente pretendido. Por sua vez, a estratégia deliberada representa as intenções totalmente realizadas (MINTZBERG, AHLSTRAND e LAMPEL, 2000).

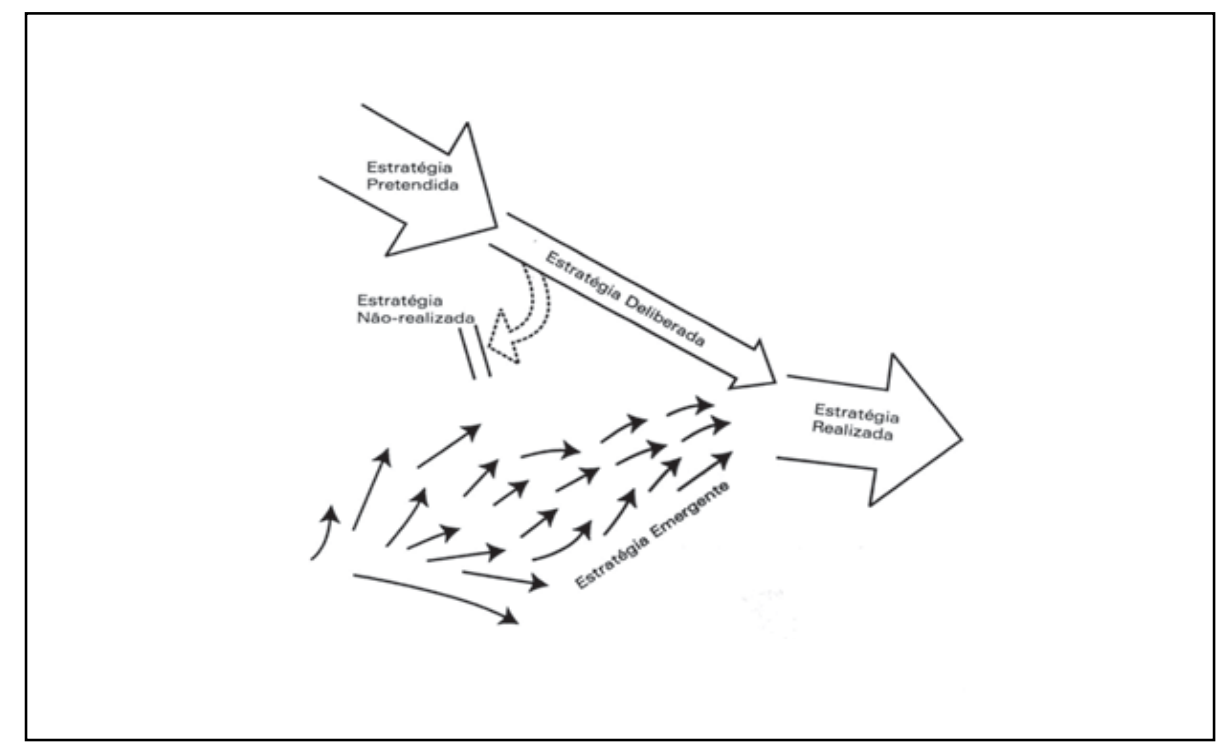

Figura 2.4: Estratégias Deliberada e Emergente Fonte: Mintzberg (2001, p.29) 
Também, podem-se considerar as quatro interpretações feitas (Marriotto, 2003) em relação ao processo de criação de estratégias emergentes. Para o autor, o processo emergente pode ser considerado como:

1. um fenômeno hierárquico que manifesta nos níveis inferiores da organização e emerge nos níveis superiores;

2. um fenômeno cognitivo que manifesta a partir do momento em que os membros da organização começam a percebê-la;

3. uma consequência da auto-organização em sistemas complexos que manifesta naturalmente de várias ações não coordenadas;

4. um fenômeno de aprendizagem que manifesta a partir do momento em que a organização corrige suas ações ou quando corrige seus próprios planos.

De acordo com Mintzberg e Waters (1985), as condições necessárias para a identificação de estratégias emergentes ou deliberadas são:

- existência ou não de intenções estratégicas explícitas;

- existência ou não de controle centralizado sobre as ações organizacionais;

- ambiente externo previsível / imprevisível ou controlável / incontrolável.

Ainda, para Mintzberg, Ahlstrand e Lampel (2000, p.143) a estratégia emergente "focaliza o aprendizado - vir a entender através da execução de ações regidas pelas intenções". Para os autores, o conceito de estratégia emergente permite o aprendizado estratégico, pois reconhece a capacidade da organização para experimentar; agrupa reflexão com resultado, visto que a análise dos resultados colide permanentemente na formulação e reformulação da estratégia (MINTZBERG, AHLSTRAND e LAMPEL, 2000, p.147).

Por fim, conclui-se que a estratégia deliberada e tradicional (processo racional e formal) não é suficiente para as empresas em vista das mudanças, desafios e pressões do dia a dia. Por outro lado, somente a criação de estratégias emergentes não proporciona pró-atividade e controle do desempenho organizacional. Dessa maneira, para serem eficazes, as ações estratégicas devem ocorrer em um processo contínuo, considerando que as estratégias intencionais são desafiadas ou revisadas pelas emergentes, que formam uma intencionada e, assim, sucessivamente. As estratégias emergentes integram ideias que surgem das atividades do di a dia dos negócios, assim como da inter-relação da empresa com seus clientes e mercado (MARIOTTO, 2003). 


\section{ORGANIZAÇ̃̃̃ E DESEMPENHO}

Este capítulo apresenta um panorama do Desempenho e do Controle Desempenho e mostra que o desempenho é o desdobramento da Estratégia. Ainda, contempla uma revisão conceitual sobre as diferentes abordagens dadas à Medição de Desempenho. Além disso são abordados a Medição de Desempenho na visão estratégica e operacional, os modelos existentes e as principais questões (barreiras e fatores favoráveis) que influenciam o uso da Medição de Desempenho. Apresenta, também, um panorama geral dos Indicadores de Desempenho contemplados pelas organizações.

\subsection{ORGANIZAÇÃO}

Sabe-se que a origem das organizações está intimamente ligada à história da sociedade humana: as organizações não são uma invenção contemporânea. Os faraós a utilizaram para construir as pirâmides, os imperadores da China a utilizaram para construir grandes sistemas de irrigação e os primeiros papas criaram uma igreja universal para servir a uma religião universal (ETZIONI, 1978).

A organização é importante em todos os níveis da vida humana: no indivíduo, nas classes de indivíduos, na comunidade e na sociedade (HALL, 1984). É indiscutivelmente o tipo de sistema social predominante da sociedade; tem papel primordial para o desenvolvimento econômico, político e social de muitos países, contribuindo para a definição da personalidade de um indivíduo (MOTTA; PEREIRA, 1980). Daft (1999) apresenta sete motivos pelos quais as organizações são importantes: produzem mercadorias e serviços para atender as necessidades dos clientes a preços competitivos; reúnem recursos para cumprir metas específicas; adaptam-se e influenciam um ambiente em rápida mutação; criam uma tendência para a inovação ao invés de padronizar seus produtos e serviços; criam valor para proprietários, clientes e 
empregados; utilizam métodos modernos de tecnologia e fabricação com base em computadores, e lidam com os atuais desafios de diversidade, ética, padrões de carreira e com a motivação e coordenação de seus empregados.

A palavra organização não tem um único sentido. Dessa maneira, ela pode ser usada em dois sentidos: o primeiro está ligado à ideia de método, de ordem, de sistematização; é o antônimo de desordem. Já o segundo designa uma entidade em que se empenham pessoas para um trabalho coordenado (ESCRIVÃO FILHO, 2006). A organização pode ser contemplada como uma coletividade que existe numa base contínua, inserida em um ambiente; é uma ordem normativa (regras), níveis de autoridade (hierarquia); suas atividades ocasionam consequências para a própria organização, para seus membros e para a sociedade (HALL, 1984). É uma entidade social, direcionada a um objetivo, deliberadamente estruturada que visa atingir as metas estratégicas (DAFT, 1999). Pode ser entendida como uma entidade autônoma que não depende particularmente de nenhum dos indivíduos e grupos que dela fazem parte (ESCRIVÃO FILHO, 2006). Por sua vez, é coordenada por suas atividades e não por pessoas (HALL, 1984). É um sistema estruturado que integra objetivos explícitos, atividades coordenadas, controle, autoridade, liderança e responsabilidade. Escrivão Filho (2006) esclarece que a organização é um sistema de atividades planejadas para a execução de um objetivo estabelecido. Consiste em um sistema de recursos que busca alcançar algum objetivo ou um conjunto deles, como fornecer alguma combinação de produtos e serviços (MAXIMIANO, 2004).

Barnard (1971) conceitua as organizações como sistemas cooperativos, ou seja, um complexo de componentes físicos, pessoais, biológicos e sociais, existindo uma relação específica em razão da cooperação de duas ou mais pessoas visando um determinado fim. As organizações "são instrumentos que conquistam seu significado e direção diretamente por sua função" (ETZIONI, 1978, p.146). Ainda, de acordo com Lawrence e Lorsch (1977, p.2), uma organização é a "coordenação de diferentes atividades de contribuintes individuais com a finalidade de efetuar transações planejadas com o ambiente".

Schein (1982) e Motta e Pereira (1980) classificam as organizações em dois tipos: informal e formal. Na organização informal, os padrões de coordenação surgem de modo implícito ou espontâneo, por meio de interações pessoais, sem implicar na coordenação para o atingimento de objetivos explícitos comuns. Está relacionada com as relações sociais que não estavam previstas em seus regulamentos e organogramas; 
desenvolve seus próprios hábitos e normas. Já na organização formal, existe a coordenação planejada das atividades de várias pessoas para a consecução de algum propósito explícito, a qual implica na divisão do trabalho, determinação de funções, hierarquia de autoridade e responsabilidades.

Há outro lado para o entender as organizações: é examinar as dimensões (estruturais e contextuais) que descrevem suas peculiaridades (DAFT, 1999):

- Dimensão estrutural: descreve as características internas organizacionais, criando uma base para medir e comparar organizações. Contempla a formalização acerca da organização, como seu volume de documentação, em comparação à pequena empresa familiar que não possui praticamente normas escritas, ou seja, é considerada informal. Outro elemento estrutural diz respeito à especialização, relacionada a quanto as tarefas da organização são subdivididas em cargos. A padronização também é abordada, pois é considerada como a extensão das atividades similares que são executadas uniformemente. Outra característica é o tipo de hierarquia de autoridade que especifica os níveis de autoridade na organização, ou seja, o escopo de controle de cada um, quem obedece a quem, sendo representada pelos organogramas. Ainda, há a complexidade, referente ao número de atividades, podendo ser medida vertical (número de níveis da hierarquia), horizontal (número de títulos de cargos ou departamentos) e espacial (número de localizações geográficas). A centralização, também uma característica estrutural, refere-se ao nível hierárquico que tem autoridade para tomar decisões: no nível mais elevado da estrutura, elas são caracterizadas como centralizadas, e quando as decisões são delegadas nos níveis mais baixos, são caracterizadas como descentralizadas. Em relação à educação formal e de treinamento dos empregados, é abordado o profissionalismo, considerado elevado quando os empregos exigem longos períodos de treinamento para se assumir determinados cargos na organização. Por fim, considera-se a distribuição de pessoas pelas várias funções e departamentos, ou seja, os graus de pessoal que incluem o grau administrativo, burocrático, assessoria profissional e a proporção de mão de obra direta pela indireta (DAFT, 1999).

- Dimensão contextual: descreve o ajuste organizacional que influencia e molda as dimensões estruturais, ou seja, caracteriza toda a organização, seu porte, tecnologia, ambiente e metas, sendo elas: dimensão, relacionada ao número de pessoas (empregados) na organização; tecnologia organizacional, que aborda a natureza do subsistema de produção, inclui as ações e técnicas utilizadas para transformar as 
entradas em saídas organizacionais. O ambiente também é destacado, pois inclui todos os elementos além dos limites organizacionais como o governo, seus clientes e os fornecedores. Em relação ao propósito e as técnicas competitivas que as diferenciam de seus concorrentes, destacam-se suas metas e estratégia, que define seu plano de ação, o escopo das operações e o relacionamento com empregados, clientes e concorrentes. Por fim, é abordada a cultura da empresa, ou seja, o conjunto subjacente de valores, crenças, conhecimentos e normas da organização.

Assim, todas essas dimensões, estruturais e contextuais, fornecem uma base para a medição e análise de características que não podem ser vistas e que revelam informações significativas sobre uma organização. A figura 3.1 apresenta a interação entre as dimensões apresentadas (DAFT, 1999).

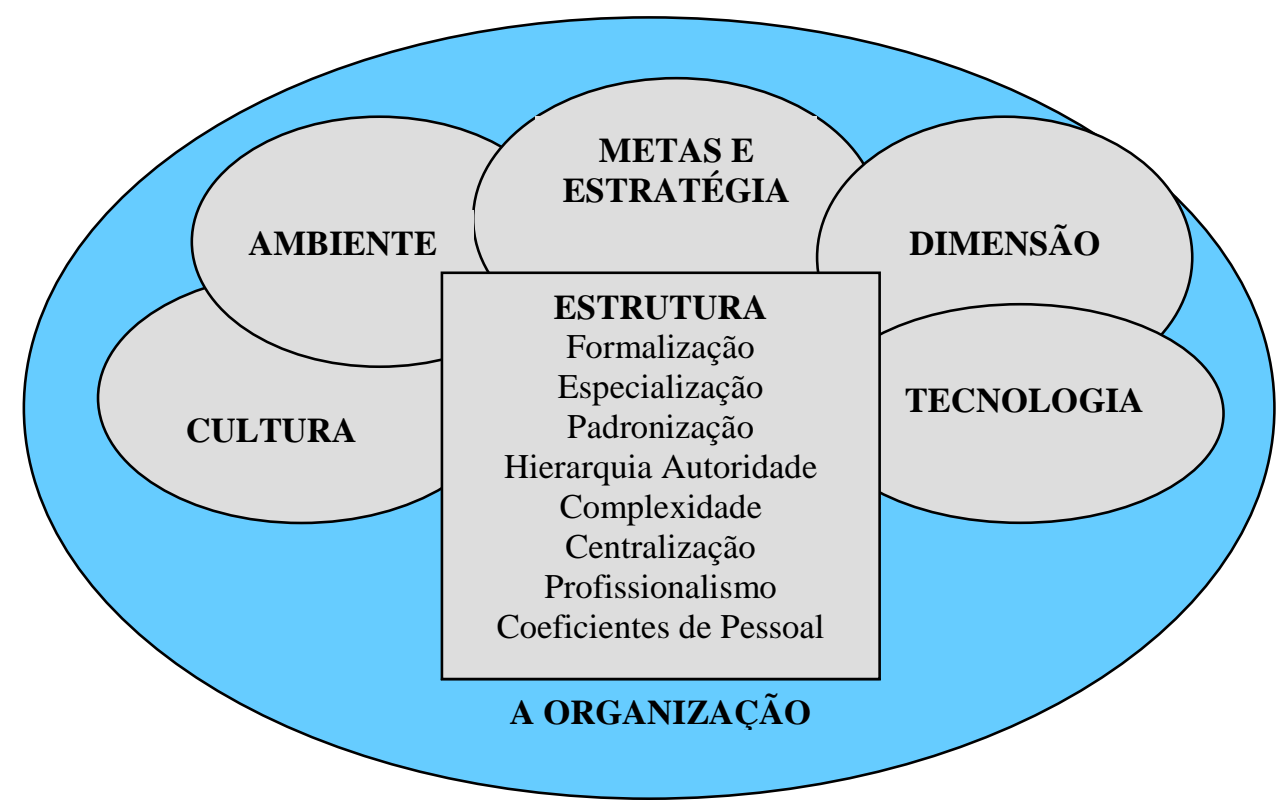

Figura 3.1: A Interação das Dimensões Contextual e Estrutural do Projeto da Organização

Fonte: Daft (1999, p.10) 


\subsection{CONTROLE DO DESEMPENHO}

Uma vez completado o planejamento, a organização deve se concentrar na atividade de controle, certificando-se de que a meta será alcançada. O primeiro passo é assegurar o uso eficiente e eficaz de seus recursos para atingir as metas pretendidas (MONTANA; CHARNOV, 1998). No contexto organizacional há diversas concepções sobre os termos de eficiência e eficácia, embora não divirjam excessivamente. Aragão (1997) sintetiza-os na relação entre o input real e o input padrão (o desejado pela organização), cujo resultado tenderia a zero. Eficiência pode ser considerada como o esforço realizado e o resultado obtido (MOTTA, 1991). Implica na relação entre resultados obtidos e custos dos recursos empregados, possuindo duas dimensões: a relativa à dotação de recursos e a referente e à produtividade dos serviços. Ainda, a eficiência organizacional é considerada como a capacidade de uma organização produzir resultados desejados com um mínimo de gasto de energia, tempo, material, dinheiro e pessoal, (MOTTA, 1991).

Por vez, a eficácia é caracterizada como o desempenho externo organizacional ao seu produto, ou seja, a contribuição para o alcance dos objetivos da organização. Pode ser caracterizada como a relação entre o output real e o output padrão, cujo resultado tenderia ao infinito. Vale destacar que a efetividade refere-se à relação entre os resultados alcançados e os objetivos pretendidos, sendo, muitas vezes, descrita como uma dimensão qualitativa do resultado (ARAGÃO, 1997).

Assim, para Ramos (1978) ser eficiente e eficaz:

"Demonstram a maior ou menor capacidade de consumir recursos escassos, disponíveis para a realização de uma tarefa determinada. Ou em outras palavras, indicam a justeza e propriedade com que a forma de elaboração de determinado produto final foi selecionada, de modo a que se minimizasse o seu custo respectivo".

Como foi apresentado, as palavras eficiência e eficácia se complementam, e conclui-se que não adianta só fazer algo, é preciso visar os resultados a serem alcançados. Para ter eficiência e eficácia, a teoria administrativa prega que o administrador deve controlar. O termo controlar significa "monitorar, avaliar e melhorar as diversas atividades que ocorrem nas organizações" (CERTO; PETER, 2005, p.132). É um processo que busca o alcance eficaz e eficiente da missão e dos objetivos da organização (SOBRAL; PECI, 2008). 
Embora haja indícios de que os conceitos sobre controle eram realizados há muitos séculos, foi no início do século XX que eles se tornaram reconhecidos como nos trabalhos de Taylor (1912), Church (1913) e Fayol (1916). Esses trabalhos repercutem até os dias de hoje e influenciam de maneira marcante a gestão e o estudo das organizações no mundo inteiro, durante mais de meio século (GOMES; SALAS, 1999).

O controle eficaz do desempenho organizacional requer informações sobre padrões de desempenho, desempenho real e ações para corrigir quaisquer desvios deles. Para tanto, os gerentes precisam desenvolver padrões, mensurações e medidas para monitorar e controlar eficazmente o desempenho da organização e elaborar sistemas para alcançá-las (DAFT, 1999, p. 476). Robbins (1978, p.449) conceitua o controle do desempenho organizacional como:

"O processo de monitoramento de atividades para determinar se as unidades individuais e a própria organização estão obtendo e utilizando seus recursos eficientemente, de modo a atingir seus objetivos e, nos casos em que isso".

De acordo Sobral e Peci (2008, p.238), o sistema de controle consiste em:

[...] conjuntos coordenados de regras, princípios e práticas que interagem de forma regular e previsível, buscando coletar informações essenciais ao processo de controle. São sistemas formais, orientados por objetivos, que monitoram, avaliam e fornecem feedback acerca do desempenho organizacional. [...] podem gerar e transmitir informações relativas a questões financeiras, contábeis, gerenciais, comerciais, operacionais, entre outras.

Planejamento e controle seguem juntos, não há controle sem planejamento; nenhum administrador controla sem planos, conforme apresenta a figura 3.2 (SOBRAL; PECI, 2008). Na maioria das organizações, a falta de controle estratégico pode danificar a saúde de uma organização e ameaçar seu futuro. Ele envolve, por exemplo, o controle da qualidade, o atendimento ao cliente, a produtividade e a eliminação de erros; regula as atividades organizacionais e as torna consistentes em relação às expectativas estabelecidas nos planos, metas e padrões de desempenho (DAFT, 1999), consistindo essencialmente numa garantia de realização da meta organizacional, monitorando e avaliando o processo de administração estratégica (CERTO; PETER, 2005). 


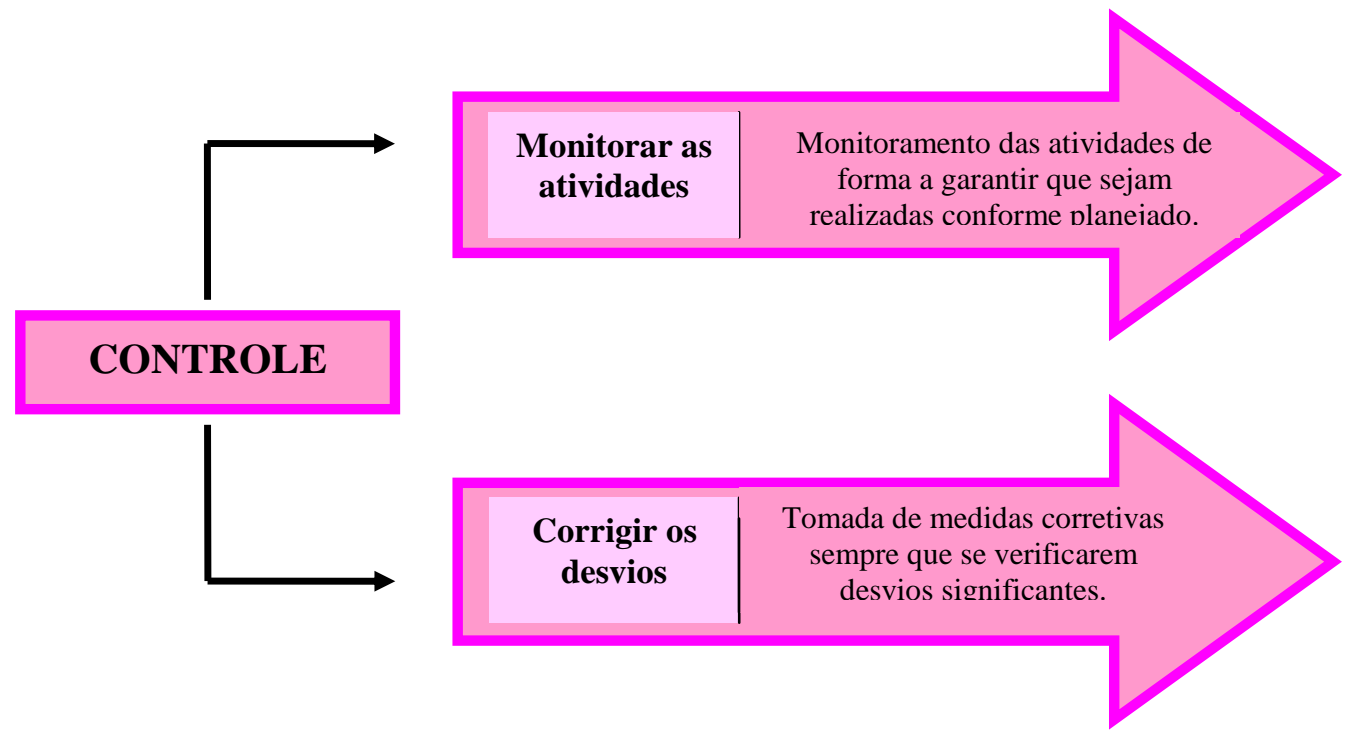

Figura 3.2: Dupla Atribuição do Controle

Fonte: Sobral; Peci (2008, p.232)

Para Koontz e O’Donnell (1982, p.225) o controle consiste em medir e corrigir o desempenho de subordinados para assegurar que os objetivos da empresa e os planos delineados para alcançá-los sejam realizados. Em outras palavras, é a certificação de que aquilo que está sendo realizado está de acordo com o que se tencionava fazer. Já para Steiner (1979) e Sobral e Peci (2008) o processo de controle está relacionado com o processo de avaliação de desempenho e de tomada de ações corretivas a partir do momento em que são encontrados desvios relacionados ao planejamento. Ainda, Hrebiniak (2006) esclarece que o controle apresenta outras características: fornece feedback ou informações sobre o desempenho em relação aos objetivos da execução; reforça os métodos e decisões de execução; garante um mecanismo corretivo mantendo o processo de execução sob controle; permite que a aprendizagem organizacional facilite as mudanças e a adaptação organizacional. Ainda, define as medidas de desempenho; verifica sistematicamente o desempenho efetivo; compara padrões e objetivos planejados e o desempenho observado; especifica os critérios que serão utilizados na medição de desempenho (SOBRAL; PECI, 2008, p.8).

Sabe-se que todo administrador deseja possuir um sistema de controle eficiente para ajudá-lo a certificar-se de que os acontecimentos se desenrolem conforme o planejado. Nesse sentido, Koontz e O’Donnell (1982, p. 229-232) apresentam os dez requisitos de controle adequados. Os controles devem: 
- refletir a natureza e as necessidades da atividade conforme o planejado;

- refletir prontamente os desvios onde eles ocorrem;

- voltar-se para o futuro, prever os desvios a tempo de fazer correções;

- apontar as exceções em pontos estratégicos, assinalar onde eles são importantes ou estratégicos para as operações;

- $\quad$ ser objetivos, ser claros e positivos;

- $\quad$ ser flexíveis, maleáveis em planos alterados;

- $\quad$ refletir o padrão organizacional;

- $\quad$ ser econômicos, valer o seu custo;

- $\quad$ ser compreensíveis;

- indicar as ações corretivas.

Deve-se atentar para o fato de que cada tipo de controle do desempenho, como de produção, qualidade e estratégico, baseia-se nas três etapas, mas deve ser adaptado às exigências do tipo específico que está sendo exercido. Para entender melhor a maneira correta da aplicação do controle nas organizações, devem-se analisar as aplicações específicas do controle estratégico (CERTO; PETER, 2005).

O processo de controle consiste em quatro etapas, conforme a figura 3.3:

1. Primeira etapa: os gerentes definem as metas para os departamentos organizacionais em termos específicos, operacionais, que incluem um padrão de desempenho para comparar as atividades da organização. Assim, devem avaliar cuidadosamente o que será medido e como irão defini-lo. Esses padrões devem ser definidos de maneira clara e precisa para que os gerentes e funcionários determinem se as atividades estão no alvo.

2. Segunda etapa: para medir o desempenho real, a maioria das organizações utilizarelatórios formais das medidas quantitativas do desempenho que os gerentes reveem quase sempre; elas devem estar relacionadas aos padrões estabelecidos na primeira etapa do controle.

3. Terceira etapa: os gerentes comparam as atividades reais aos padrões de desempenho, visto que, quando o desempenho se desvia de um padrão, eles devem interpretar o desvio, procurando a causa do problema.

4. Quarta etapa: os gerentes determinam quais mudanças; caso necessário, se requer. 


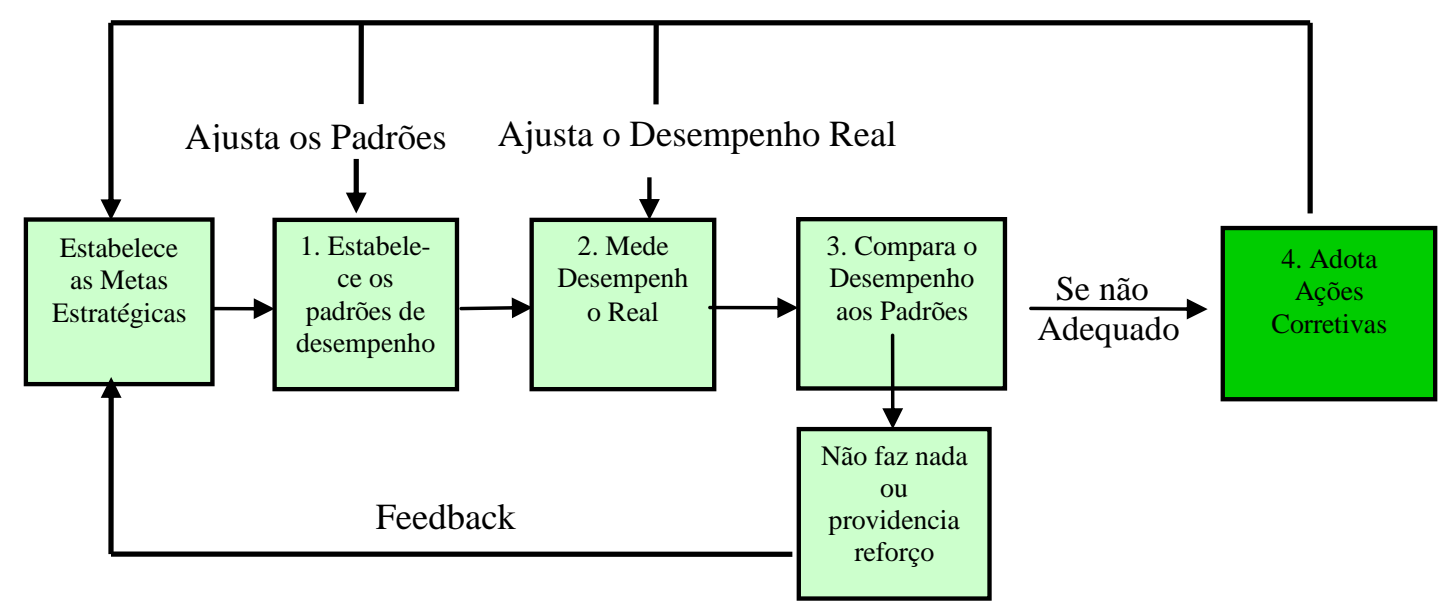

Figura 3.3: Modelo de Controle pelo Feedback Fonte: Daft (1999, p.381)

$\mathrm{Na}$ abordagem tradicional de cima para baixo, eles exercitam sua autoridade formal para realizar mudanças. Contraditoriamente, na abordagem de controle participativo, os gerentes colaboram com os funcionários na busca da ação corretiva requerida, tomam as ações corretivas para mudar os padrões de desempenho.

\subsection{DESEMPENHO E MEDIÇÃO DE DESEMPENHO}

O conhecimento da organização por parte dos executivos é o ponto chave para um enfoque adequado do desempenho organizacional. Gerenciar o desempenho deve ser realizado de forma contínua, com base nos processos organizacionais (RUMMLER; BRACHE, 1994, p.73) e deve ser feito em todas as áreas críticas destacadas pelos objetivos organizacionais (CERTO; PETER, 2005). Assim, coletadas as medidas organizacionais e comparadas com os objetivos estabelecidos, os administradores devem efetivar a ação corretiva com o intuito de alcançar os objetivos estabelecidos (CERTO; PETER, 2005). Desse modo, o desempenho da organização reflete o de seus administradores (MAXIMIANO, 2004).

O desempenho organizacional pode ser entendido como o conjunto de resultados que a organização vai efetivando à medida que suas atividades são executadas. Dado que a organização não pode "navegar" como uma "nau à deriva", pois o resultado poderia ser desastroso para muitos grupos sociais (os investidores, os 
clientes, os funcionários, a comunidade, etc.), a ação de seus administradores em conduzir a trajetória da organização para resultados desejados (um bom desempenho) é fundamental (SOBRAL; PECI, 2008).

Como a própria definição de administração associa a ação dos administradores aos conceitos de eficiência e eficácia, Certo e Peter (2005), consequentemente, relacionam o desempenho organizacional a esses conceitos, afirmando que o "desempenho organizacional envolve eficiência e eficácia", ou seja, alcança os resultados desejados (ser eficaz), usando bem os recursos disponíveis (ser eficiente).

O termo "medir" é entendido como "determinar ou verificar, tendo por base uma escala fixa, a extensão, medida ou grandeza" (FERREIRA, 1993, p. 357). Afinal, o que não pode ser medido não pode ser gerenciado (KAPLAN; NORTON, 1997; HARRINGTON, 1993). Embora seja comum, nas empresas, avaliar resultados e desempenhos, não é uma tarefa tão simples. Primeiramente, é necessário estabelecer o que se pretende medir e, posteriormente definir as medidas adequadas que avaliem o que se quer medir. Um levantamento feito por Martins (1998) sobre diversos periódicos internacionais, nacionais e anais de congressos no período de 1980/1997 revela o crescente interesse pelo tema.

A medição de desempenho é definida de várias formas e pode ser considerada de diferentes maneiras de acordo com a visão de alguns autores que estudam o assunto, como:

- quantifica a eficiência e a eficácia das atividades de negócio (NEELY et al., 1995);

- alimenta o sistema de incentivos dos funcionários (MIRANDA; SILVA, 2002);

- comunica a estratégia, clareia valores e melhora o controle e planejamento (KAYDOS, 1991);

- quantifica o resultado dentro de um processo e verifica se este atende as metas específicas da empresa (HRONEC, 1994);

- controla o planejamento (MIRANDA; SILVA, 2002);

- quantifica variáveis e atributos de interesses do objeto a ser analisado (KIYAN, 2001);

- cria, implanta e conduz estratégias competitivas (MIRANDA; SILVA, 2002);

- identifica problemas que necessitem intervenção de gestores (MIRANDA; SILVA, 2002) ; 
- é um sistema de alerta que envolve prevenção e identificação para a obtenção do melhor uso dos produtos ou serviços e satisfação dos clientes (NAURI, 1998; DE ROLT, 1998);

- alimenta o sistema de incentivos dos funcionários (MIRANDA; SILVA, 2002);

- conhece e mede a atuação dos indivíduos ou dos processos na organização, estabelecendo uma comparação entre o desempenho apresentado (LOTTA, 2002) ;

- controla as atividades operacionais da empresa (MIRANDA; SILVA, 2002);

- identifica se a missão da empresa está sendo atingida (MIRANDA; SILVA, 2002).

"A medição é o processo que envolve a decisão quanto ao que medir, como coletar, processar e avaliar os dados e, através de sua incorporação às atividades da empresa, é que se obtêm os dados e fatos necessários à tomada de decisão" (LANTELME, 1994, p.1).

A medição ajuda a identificar o que está acontecendo com o desempenho da empresa, quais as razões de sua situação atual e quais ações podem vir a ser tomadas (BOND, 1999); e sobre o ponto de vista gerencial, proporciona o feedback, o que proporciona o controle do processo e possibilita a delegação e mudança na cultura organizacional (PRANCIC; MARTINS, 2003). Por sua vez, medir o desempenho só ocorre quando existe o objetivo de aperfeiçoá-lo (BANDEIRA, 1997, p. 111), ou seja, está inserido no sentido de melhoria. Vale destacar que a falta de medição de desempenho organizacional pode levar a uma série de problemas como o não gerenciamento do próprio desempenho, não identificação de problemas e oportunidades, não compreensão sobre o que se espera das pessoas, a falta de feedback em relação à verificação do desempenho das pessoas, entre outros (RUMMLER; BRACHE, 1994, p. 197).

A medição de desempenho pode ser vista de diferentes recortes. Primeiro, pode individualmente - o elemento fundamental propriamente dito -, mas também pode em conjunto (SMD) (ATTADIA; MARTINS, 2003). Esse SMD formado por um conjunto de métricas ou indicadores de desempenho é usado para representar os resultados ou quantificar a eficiência e a eficácia das ações de melhoria nas empresas, conforme Neely et al. (1995).

Autores como Kaplan e Norton (1996); Hronec (1994) e Neely (1998), acreditam que a medição de desempenho auxilia o processo de melhoria contínua da organização. Assim, para que ela estimule a melhoria contínua, os objetivos de todas as áreas precisam ser alinhados e as necessidades de cada nível funcional devem ser 
monitoradas por medidas de desempenho para serem utilizadas por todos os membros do grupo para a realização de correções no desempenho (LEE; DALE, 1998). Enfim, a medição é apenas um dos aspectos que suportam a melhoria contínua; apresenta forte poder retórico como parte da linguagem da melhoria contínua, induzindo o comportamento dos membros da organização para a ação (ATTADIA; MARTINS, 2003).

Para usar a medição de desempenho, é necessário posicioná-la dentro de um contexto estratégico na empresa. Por vez, é um instrumento que pode influenciar o comportamento das pessoas e direcionar as ações de melhoria que são implementadas (NEELY et al., 1995; HRONEC, 1994). Nesse sentido, ela apresenta uma estrutura com indicadores relacionados com várias dimensões competitivas, como de qualidade, tempo, flexibilidade, finanças, satisfação do cliente, recursos humanos, qualidade dos fornecedores, operações, meio ambiente, entre outras. Ela reflete a realidade da empresa, e pode ser considerada como um elemento estratégico de acompanhamento, de comparação, direcionador de falhas e de decisões frente à concorrência.

Vale considerar a mudança do enfoque da medição de desempenho nas organizações conforme apresentado abaixo (Quadro 3.1). Percebe-se o deslocamento da tarefa (antes) para o os processos e melhorias contínuas (hoje).

\begin{tabular}{|c|c|}
\hline ANTES & HOJE \\
\hline Medição dos produtos & Medição de processos e serviços \\
\hline Administração de lucros & Administração de recursos \\
\hline Realização de metas & Aperfeiçoamento contínuo \\
\hline Medições de quantidades & $\begin{array}{c}\text { Medições de eficácia, eficiência e } \\
\text { adaptabilidade }\end{array}$ \\
\hline $\begin{array}{c}\text { Medições baseadas em especificações } \\
\text { técnicas e empresariais }\end{array}$ & $\begin{array}{c}\text { Medições baseadas nas expectativas } \\
\text { dos clientes (internos e externos) }\end{array}$ \\
\hline Atenção concentrada no individuo & $\begin{array}{c}\text { Atenção centrada no processo } \\
\text { Processo imposto de cima para baixo }\end{array}$ \\
$\begin{array}{c}\text { Equipe desenvolve e gerencia o } \\
\text { desempenho }\end{array}$ \\
\hline
\end{tabular}

Quadro 3.1: Mudanças na Medição de Desempenho Fonte: Adaptado de Harrington (1993, p.212) 


\subsection{Nível Estratégico: Medindo o Cumprimento da Orientação Estratégica}

Falar em medição de desempenho no nível estratégico é assegurar que a organização cumpra sua missão de modo eficaz, atendendo às necessidades dos que a controlam ou que detêm poder sobre ela. Assume a perspectiva mais ampla, a mais abstrata da organização (MINTZBERG, 2003, p.24-25).

A medição de desempenho é o início para o aperfeiçoamento da própria empresa, pois permite ao administrador saber quais são as metas organizacionais (HARRINGTON, 1993); é usada para controlar a direção estratégica organizacional e direcionar programas de melhorias relacionados com a estratégia (BITITCI et al., 1998). Ainda, a medição de desempenho "comunica aquilo que é importante para a organização para que todos possam trabalhar para a implementação da estratégia, consecução das metas e melhoria da organização" (FERRAZ, 2003, p.5).

As medidas de desempenho são sinais vitais da organização. Comunicam a estratégia para baixo, os resultados dos processos para cima e o controle e melhoria dentro dos processos (HRONEC, 1994), conforme a figura 3.4. As medidas de desempenho são o ponto de partida para o aperfeiçoamento da empresa, pois permitem ao administrador conhecer as metas organizacionais (HARRINGTON, 1993). Dessa maneira, a eficiência relaciona-se à capacidade de a organização utilizar seus recursos de modo adequado ao estabelecido, como, por exemplo, as metas de produtividade e qualidade.

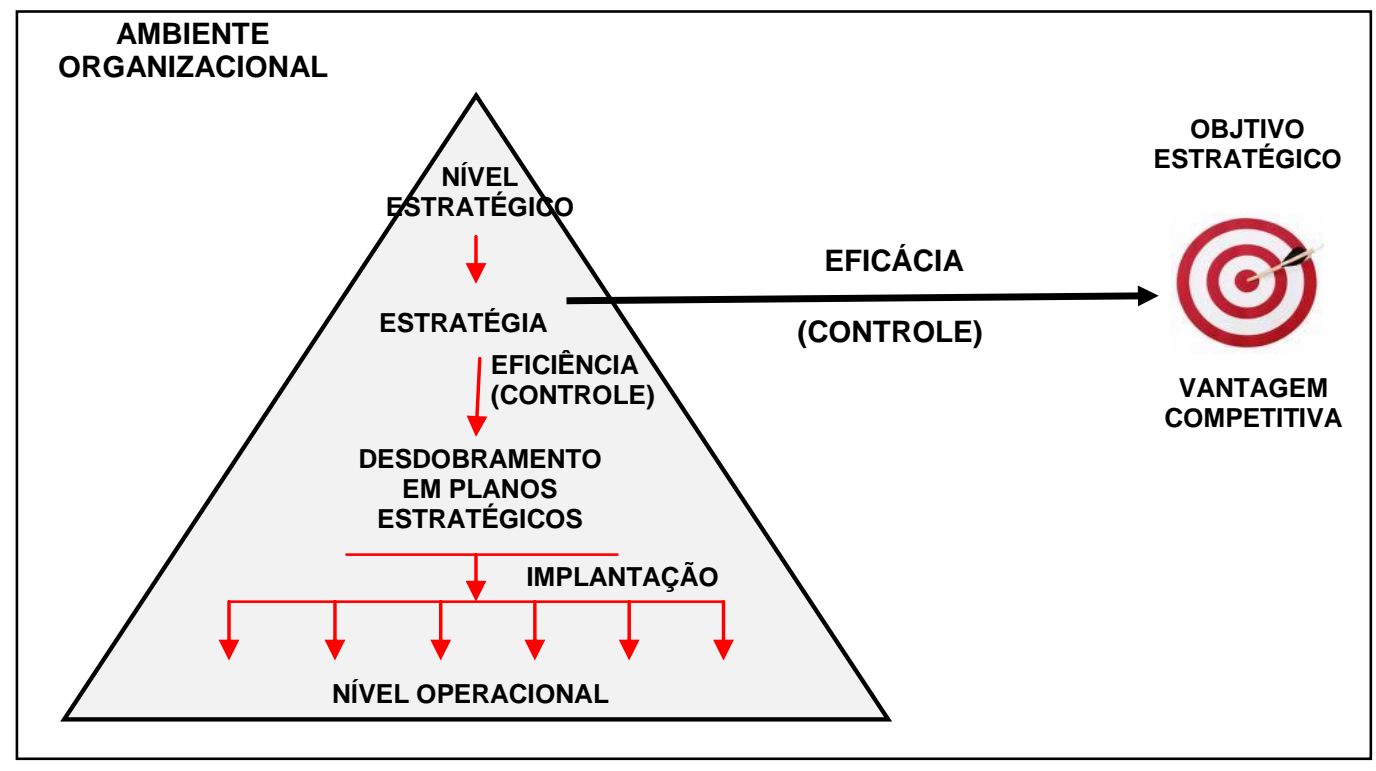

Figura 3.4: O Desdobramento da Estratégia 
Em todas as aplicações atribuídas à medição de desempenho, todas buscam contribuir para a efetivação da estratégia da organização. Para Kaplan e Norton (1996b), a medição de desempenho deve se tornar um veículo viabilizador da estratégia da empresa. Por meio da medição de desempenho são estimulados os comportamentos adequados ao alcance dos objetivos estratégicos (NEELY et al., 1995). Ainda, para McGee e Prusak (1995, p.183), ela é um elemento de ligação da estratégia com a sua execução, conforme a Figura 3.5. O sucesso estratégico não é somente a composição de um novo posicionamento de produto/mercado, por exemplo, mas, sua maior capacidade para executar e de fazer com que estes planos se tornem parte das atividades diárias organizacionais (KIYAN, 2001).

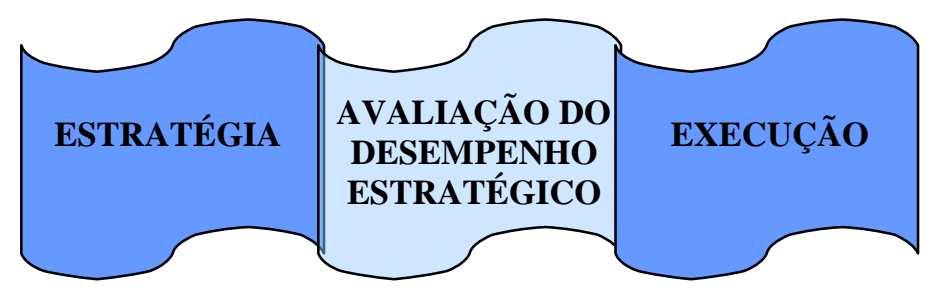

Figura 3.5: A Medição de Desempenho Estratégico como Elemento de Ligação Fonte: McGEE e Prusak (1995, p. 184)

Desta maneira, a medição de desempenho centralizada na estratégia pode ser usada para induzir ações e comportamentos, sendo primordial para alinhar e comunicar a estratégia (KAPLAN; NORTON, 1992; NEELY et al., 1995).

Considerando que qualquer medição exerce um efeito sobre o que está sendo medido, consequentemente, a medição pode ser usada como linguagem da estratégia para incitar os membros da organização à ação, a favor do alcance dos objetivos estratégicos (MARTINS, 1998).

Certo e Peter (2005, p.137-138) apresentam cinco questões que devem ser respondidas para se obter uma correta medição de desempenho organizacional em relação à consecução da estratégia proposta:

- A estratégia da organização é consistente internamente?

- A estratégia da organização é consistente com seu ambiente?

- A estratégia da organização é correta em vista dos recursos da organização?

- A estratégia da organização é muito arriscada?

- A sua duração é apropriada? 
Contudo, Lorange (1982, p.115-116) contempla que, para se obter uma correta medição do desempenho organizacional do ponto de vista estratégico, em vez de somente do operacional, deve-se atentar para cinco características:

- Necessidade de fontes de dados tanto interna quanto externa à organização, pois reforçam as importâncias estratégicas das informações de fora da organização;

- Necessidade de orientação (informações) para o futuro, fundamental para a estratégia;

- Maior atenção em medir com precisão a premissa da decisão, verificando se ela é correta e apropriada, tanto quantitativamente como qualitativamente;

- Se os padrões de controle são baseados em fatores externos;

- Estabelecimento de intervalos prefixados para os relatórios e verificações (controle).

Ainda, a medição de desempenho estará em consonância com a estratégia da empresa se algumas características forem respeitadas no processo: o primeiro passo é definir a estratégia e, posteriormente, o sistema de medição de desempenho; os indicadores devem sempre mudar quando houver mudanças na estratégia; tanto os indicadores de desempenho como a estratégia devem ser alinhados com as metas organizacionais para a maximização da criação de valor; os indicadores de desempenho devem ajudar a sincronizar as atividades estratégicas (percepção e execução das atividades); mensurar o desempenho estratégico visa refletir o pensamento e a atuação da administração a fim de assegurar a viabilidade das estratégias (FRIGO, 2002).

\subsubsection{Modelos de Medição de Desempenho Organizacional}

Existem vários modelos de medição de desempenho. Muitos autores focaram seus estudos em modelos de medição de desempenho das organizações, definindo, por exemplo, sua formulação, características, escopo, premissas, enfoque, etapas e fatores críticos de sucesso (HARRINGTON, 1993; HAMPTON, 1992; RUMMLER; BRACHE, 1994; FRIGO, 2002). Dentre os novos modelos de medição de desempenho, os que mais se destacam na literatura são apresentados no quadro 3.2. Ainda, são apresentadas no quadro 3.3 as principais características de alguns modelos de medição de desempenho. Certamente, não se teve a pretensão, nem de enumerar, nem tampouco de analisar todas as ferramentas disponíveis na literatura. 


\begin{tabular}{|c|c|}
\hline MODELO & AUTOR \\
\hline $\begin{array}{c}\text { Integrated Perfomance } \\
\text { Measurement Systems (IPMS) }\end{array}$ & BITITCI et al., 1997; \\
\hline Balanced Scorecard (BSC) & $\begin{array}{c}\text { KAPLAN e NORTON (1992;1993; 1997); KAPLAN } \\
\text { HO; MAPLAN e NORTON (1996a-b) MARTINS (1999); } \\
\text { PEREIRA; FRANKLIN; GARD (2001); POPADIUK; } \\
\text { (2006); HUDSON (2001); AIDAR (2003); NORREKLIT } \\
\text { (2000); BANKER, CHANG, e PIZZINI (2004) }\end{array}$ \\
\hline Performance Prism ((PP) & NEELY e ADAMS (2001) \\
\hline $\begin{array}{c}\text { Performance Measurement } \\
\text { Questionnaire (TQM) }\end{array}$ & $\begin{array}{c}\text { DIXON et al. (1990); McMANN e NANNI (1994); } \\
\text { RUMMLER e BRACHE (1994);DE RON (1995) }\end{array}$ \\
\hline $\begin{array}{c}\text { Performance Pyramid - } \\
\text { SMART }\end{array}$ & CROSS e LINCH(1990); McNAIR et al. (1990) \\
\hline $\begin{array}{c}\text { Consistent Performance } \\
\text { Management Systems (PMS) }\end{array}$ & FLAPPER et al. (1996) \\
\hline
\end{tabular}

Quadro 3.2: Modelos de Medição de Desempenho

Fonte: Adaptado de Martins (1998)

\begin{tabular}{|c|c|c|c|c|c|}
\hline Características dos Modelos de Medição de Desempenho & SMART & PMS & BSC & IPMS & $\mathbf{P P}$ \\
\hline \multicolumn{6}{|l|}{ Prática de MD: } \\
\hline $\begin{array}{l}\text { Definir as necessidade e contribuições dos } \\
\text { stakeholders }\end{array}$ & & & $\mathrm{X}$ & & $\mathrm{X}$ \\
\hline Derivar da estratégia da empresa & $X$ & $\mathrm{X}$ & $\mathrm{X}$ & $\mathrm{X}$ & \\
\hline $\begin{array}{l}\text { Integrar as operações com as metas } \\
\text { estratégicas }\end{array}$ & $\mathrm{X}$ & $\mathrm{X}$ & $\mathrm{X}$ & $\mathrm{X}$ & $\mathrm{X}$ \\
\hline Estimular a melhoria contínua & & $\mathrm{X}$ & $\mathrm{X}$ & $\mathrm{X}$ & $\mathrm{X}$ \\
\hline Assegurar o feedback & $\mathrm{X}$ & & & $\mathrm{X}$ & $\mathrm{X}$ \\
\hline Definir claramente o propósito & & $\mathrm{X}$ & $\mathrm{X}$ & $\mathrm{X}$ & $\mathrm{X}$ \\
\hline Relevantes e fáceis de manter & $\mathrm{X}$ & $\mathrm{X}$ & & $\mathrm{X}$ & $\mathrm{X}$ \\
\hline Ser simples para usar e entender & $\mathrm{X}$ & $\mathrm{X}$ & $\mathrm{X}$ & $\mathrm{X}$ & $\mathrm{X}$ \\
\hline \multicolumn{6}{|l|}{ Desenvolvimento da MD } \\
\hline Avaliar as métricas que existem na empresa & $\mathrm{X}$ & & & $\mathrm{X}$ & $\mathrm{X}$ \\
\hline Identificar os objetivos estratégicos & & & $\mathrm{X}$ & $\mathrm{X}$ & $\mathrm{X}$ \\
\hline $\begin{array}{l}\text { Assegurar o desenvolvimento das } \\
\text { métricas }\end{array}$ & & $\mathrm{X}$ & $\mathrm{X}$ & $\mathrm{X}$ & $\mathrm{X}$ \\
\hline Fornecer uma estrutura de manutenção & & $\mathrm{X}$ & & $\mathrm{X}$ & $\mathrm{X}$ \\
\hline $\begin{array}{l}\text { Estabelecer um número balanceado de } \\
\text { métricas }\end{array}$ & $\mathrm{X}$ & $\mathrm{X}$ & $\mathrm{X}$ & $\mathrm{X}$ & $\mathrm{X}$ \\
\hline Envolver os usuários & $\mathrm{X}$ & $\mathrm{X}$ & & $\mathrm{X}$ & $\mathrm{X}$ \\
\hline Dar suporte na gestão do negócio & $\mathrm{X}$ & $\mathrm{X}$ & $\mathrm{X}$ & $\mathrm{X}$ & $\mathrm{X}$ \\
\hline Dar suporte aos funcionários & $\mathrm{X}$ & $\mathrm{X}$ & $\mathrm{X}$ & $\mathrm{X}$ & $\mathrm{X}$ \\
\hline Ter os objetivos claros e explícitos & & & $\mathrm{X}$ & $\mathrm{X}$ & $\mathrm{X}$ \\
\hline Ter uma escala de tempo & & & $\mathrm{X}$ & & $\mathrm{X}$ \\
\hline \multicolumn{6}{|l|}{ Categorias de desempenho: } \\
\hline Qualidade & $\mathrm{X}$ & & $\mathrm{X}$ & $\mathrm{X}$ & $\mathrm{X}$ \\
\hline Flexibilidade & $\mathrm{X}$ & & $\mathrm{X}$ & $\mathrm{X}$ & $\mathrm{X}$ \\
\hline Тетро & $\mathrm{X}$ & & $\mathrm{X}$ & $\mathrm{X}$ & $\mathrm{X}$ \\
\hline Finanças & $\mathrm{X}$ & & $\mathrm{X}$ & $\mathrm{X}$ & $\mathrm{X}$ \\
\hline Satisfação do consumidor & $\mathrm{X}$ & & $\mathrm{X}$ & $\mathrm{X}$ & $\mathrm{X}$ \\
\hline Recursos Humanos & $\mathrm{X}$ & & $\mathrm{X}$ & $\mathrm{X}$ & $\mathrm{X}$ \\
\hline
\end{tabular}

Quadro 3.3: Comparação dos Modelos de Medição de Desempenho

Fonte: adaptado de Garengo et al. (2005) e Hudson (2001)

3 Stakeholders pode ser entendido como os clientes, empregados, fornecedores, acionistas e sociedade. (ATKINSON et al., 1997). 


\subsubsection{O Nível Tático: Ligando o Estratégico ao Operacional}

O BSC (Balanced Scorecard), desenvolvido por Kaplan e Norton (1996), é o modelo apontado como o mais utilizado pelas empresas em um estudo feito pela empresa de consultoria Bain \& Company, segundo o qual 55\% das empresas nos EUA e 45\% na Europa o utilizam (Kaplan e Norton, 1999, p. 1). É um sistema de gestão estratégica, que comunica e alinha a estratégia para toda a empresa e possibilita o feedback para se ter um maior conhecimento da estratégia e aperfeiçoá-la (KAPLAN; NORTON, 1992; ATTADIA, 2004; FERRAZ, 2003).

Também apelidado por algumas empresas brasileiras como "painel de bordo", é um sistema de medição de desempenho que esclarece que os indicadores financeiros, sozinhos, não são suficientes para avaliar o desempenho da organização (AIDAR, 2003). É um método de gestão de desempenho que analisa a integração e o agrupamento de indicadores de desempenho financeiros e não financeiros através de quatro perspectivas de avaliação (KAPLAN; NORTON, 1997; NORREKLIT, 2000), conforme apresentado na figura 3.6:

1. dos clientes (identificação do perfil do cliente, dos mercados e das ações necessárias);

2. financeira (expressa os resultados econômicos e indica se a estratégia da organização esta voltada para a melhoria dos resultados financeiros);

3. dos processos internos (permite a empresa desenvolver mecanismos para direcionar seus resultados desejados aos clientes e ao mercado com o intuito do retorno financeiro dos proprietários);

4. do aprendizado e crescimento (identificação da infraestrutura a ser construída para gerar o crescimento e melhoria da empresa a longo prazo).

Em outras palavras, o modelo busca responder quatro perguntas (KAPLAN; NORTON, 1997): 1) Como os consumidores nos veem? (perspectiva do consumidor);

2) Em que devemos nos exceder? (perspectiva dos processos internos); 3) Como nós continuaremos a melhorar e a criar valor? (perspectiva da aprendizagem e crescimento) e; 4) Como assistimos aos nossos acionistas? (perspectiva financeira). É um sistema capaz de compreender a estratégia empresarial e comunicá-la a toda a organização (KAPLAN ; NORTON, 2001; BANKER; CHANG; PIZZINI, 2004). 


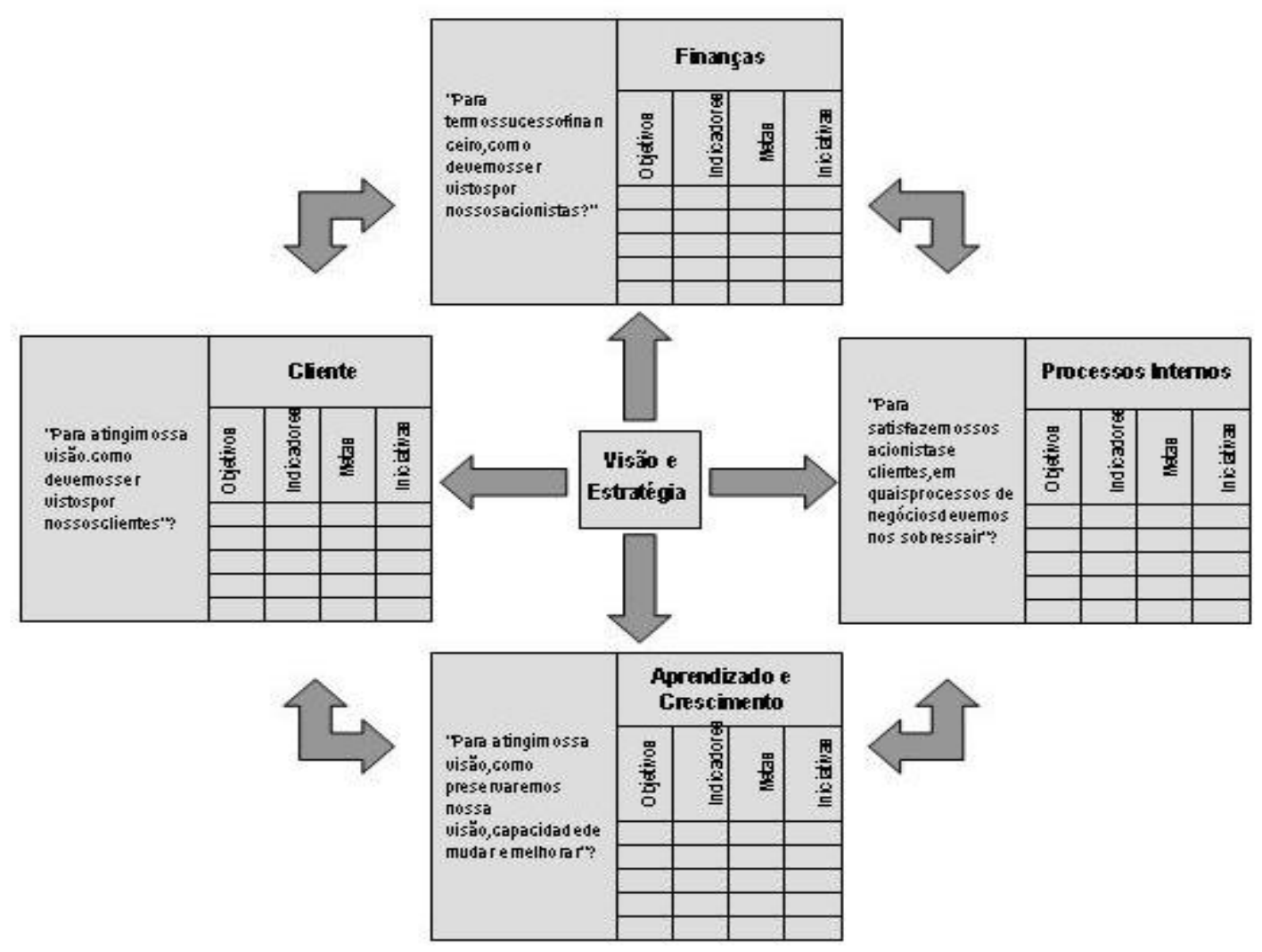

Figura 3.6: As Perspectivas do Balanced Scorecard

Fonte: Adaptado de Kaplan e Norton (1996)

Como principais características do modelo BSC, têm-se:

- Comunica a estratégia para toda a organização (KAPLAN; NORTON, 1997);

- Complementa a medição do desempenho da estratégia organizacional com a utilização de enfoques não financeiros (HO; McKAY, 2002);

- Centraliza os resultados (objetivos estratégicos do negócio) (ÁLVARO, 2001);

- Estrutura de relações de causa-efeito entre as métricas e as perspectivas de desempenho (ÁLVARO, 2001);

- Eleva o equilíbrio entre o número de objetivos e entre o número de métricas utilizadas na empresa (ÁLVARO, 2001);

- "Reflete várias perspectivas da empresa e motiva as equipes na medida em que se aproxima a estratégia dos objetivos e ações operacionais" (POPADIUK et al., 2006 p. 157).

Entretanto, como críticas ao BSC, têm-se: 
- O modelo falha, pois não incorpora métodos de identificação dos processos críticos ou porque as oportunidades de melhoria estão relacionadas aos objetivos estratégicos (ÁLVARO, 2001);

- Não está relacionado com a definição das características dos indicadores (SCHNEIDERMAN, 1999);

- Não esclarece como construir a ligação entre os indicadores das perspectivas de desempenho, definidas como independentes (NORREKLIT, 2000);

- Não promove a participação dos usurários da informação no desenvolvimento da medição de desempenho (HUDSON, 2001).

Assim, o BSC traduz a missão e a estratégia de uma empresa em objetivos e medidas tangíveis que representam um equilíbrio entre indicadores externos voltados para acionistas e clientes, e as medidas internas dos processos críticos de negócios, inovação, aprendizado e crescimento. É um modelo utilizado por executivos que necessitam tomar decisões visando o atingimento do planejamento estratégico da organização; motiva os funcionários a contribuírem para a melhoria do desempenho organizacional (NEELY, 1998) bem como encoraja o comportamento adequado ao alcance dos objetivos estratégicos (NEELY et al., 1995).

\subsection{INDICADORES DE MEDIÇÃO DE DESEMPENHO}

De acordo com Takashina e Flores (1996), os indicadores são essenciais ao planejamento e controle organizacional. São considerados importantes ao planejamento pois possibilitam o estabelecimento de metas quantificáveis e o seu desdobramento em todos os níveis organizacionais, e são essenciais ao controle do desempenho organizacional pois os resultados apresentados através dos indicadores fornecem uma analise crítica do desempenho da organização, para as tomadas de decisões e para o replanejamento.

Os indicadores devem sempre estar orientados para os resultados do negócio, de forma a direcionar as ações da organização, entregando sempre um melhor valor ao cliente e aprimorando seu desempenho. É importante considerar que, nos níveis mais elevados da estrutura organizacional, os indicadores, bem como as metas em geral, são fortemente relacionados aos objetivos e estratégias da organização. À medida que são desdobrados na estrutura organizacional, ambos se tornam mais influenciados pelos 
indicadores e metas do nível superior, embora não se deva perder de vista os objetivos e estratégias como em grandes organizações, conforme a figura 3.7 (TAKASHINA; FLORES, 1996).

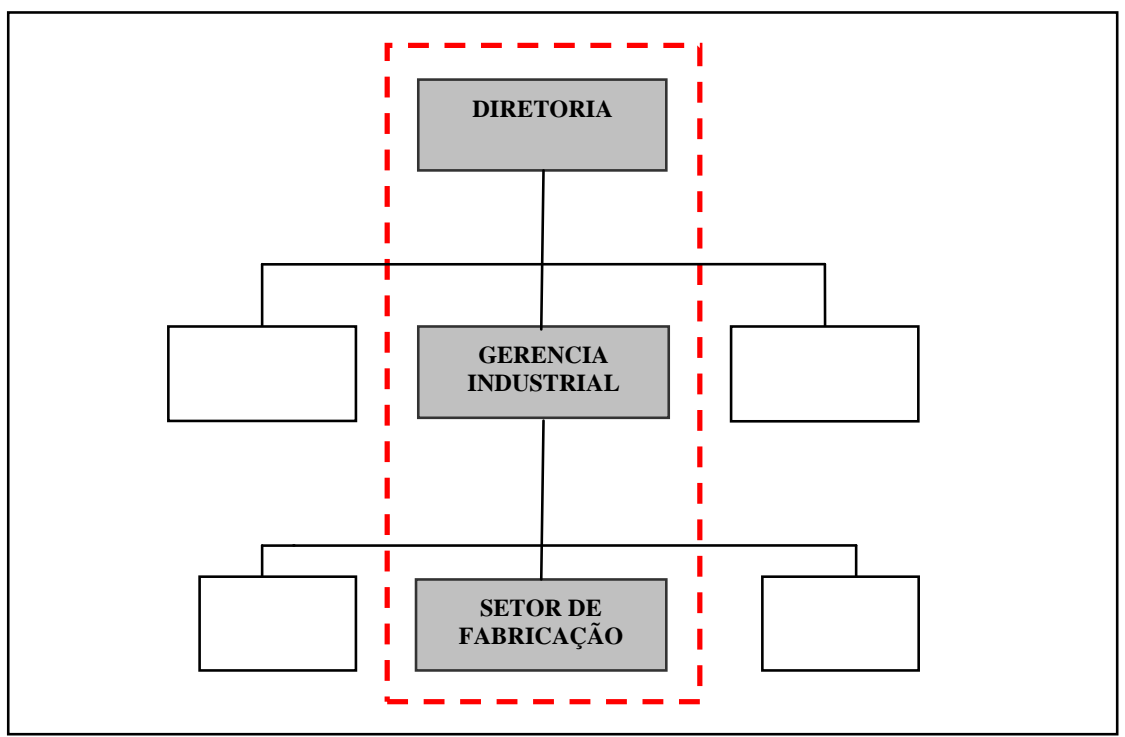

Figura 3.7: Exemplos de indicadores desdobrados na estrutura organizacional Fonte: Takashina e Flores (1996, p.53)

Com efetivo controle do desempenho, é possível melhorar gradativamente a atuação das empresas, mantendo-as competitivas por meio de indicadores de desempenho e ferramentas de medição adequadas, que permitam comparar o desempenho esperado e o alcançado pelas empresas. A medição de desempenho pode contribuir para o entendimento de mudanças estratégicas e operacionais. É obtida através de uma interação entre as informações do ambiente interno e externo, através da identificação de problemas financeiros, e do cuidado com a satisfação dos clientes e de outros participantes das empresas. Dessa maneira, a operacionalização da medição de desempenho ocorre através dos indicadores de desempenho (HOURNEAUX JÚNIOR, 2005).

Os indicadores também são considerados como formas de representação quantificáveis das características dos produtos e processos; mostram níveis, tendências e fazem comparações. São utilizados para controlar e melhorar a qualidade de seus produtos e processos. Com os resultados dos indicadores, a organização avalia o seu desempenho em relação à meta e a outros referenciais, subsidiando as tomadas de decisões e o replanejamento (TAKASHINA; FLORES, 1996). Segundo os autores, um 
indicador deve ser gerado de forma a assegurar a disponibilidade de dados e resultados, conforme a tabela 3.1 .

\begin{tabular}{|l|l|}
\hline \multicolumn{1}{|c|}{ Critérios } & \multicolumn{1}{c|}{ Descrição } \\
\hline $\begin{array}{l}\text { Seletividade ou } \\
\text { importância }\end{array}$ & Capta uma característica-chave do produto ou do processo \\
\hline $\begin{array}{l}\text { Simplicidade e } \\
\text { clareza }\end{array}$ & $\begin{array}{l}\text { Fácil compreensão e aplicação em diversos níveis da } \\
\text { organização, numa linguagem acessível }\end{array}$ \\
\hline Abrangência & $\begin{array}{l}\text { Suficientemente representativo, inclusive em termos estatísticos, } \\
\text { do produto ou do processo a que se refere: devem-se priorizar } \\
\text { indicadores representativos de situação ou contexto global }\end{array}$ \\
\hline $\begin{array}{l}\text { Rastreabilidade e } \\
\text { acessibilidade }\end{array}$ & $\begin{array}{l}\text { Permite o registro e a adequada manutenção e disponibilidade } \\
\text { dos dados, resultados e memórias de cálculo, incluindo os } \\
\text { responsáveis envolvidos. É essencial à pesquisa dos fatores que } \\
\text { afetam o indicador. (Os dados podem ser armazenados em } \\
\text { microfilme, meio eletromagnético, relatórios, etc.) }\end{array}$ \\
\hline Comparabilidade & $\begin{array}{l}\text { Fácil de comparar com referenciais apropriados, tais como o } \\
\text { melhor concorrente, a média do ramo e o referencial de } \\
\text { excelência }\end{array}$ \\
\hline $\begin{array}{l}\text { Estabilidade e } \\
\text { rapidez de } \\
\text { disponibilidade }\end{array}$ & $\begin{array}{l}\text { Perene e gerado com base em procedimentos padronizados, } \\
\text { incorporados às atividades do processador. Permite fazer uma } \\
\text { previsão do resultado, quando o processo está sob controle }\end{array}$ \\
\hline $\begin{array}{l}\text { Baixo custo de } \\
\text { obtenção }\end{array}$ & $\begin{array}{l}\text { Gerado a baixo custo, utilizando unidades adimensionais } \\
\text { simples, tais como percentagem, unidades de tempo, etc. }\end{array}$ \\
\hline
\end{tabular}

Tabela 3.1: Principais critérios para geração de um indicador Fonte: Takashina e Flores (1996, p.25)

Segundo Miranda e Silva (2002), o processo de medição de desempenho consiste em um conjunto de indicadores e relatórios que a organização deve utilizar para avaliar seu desempenho no mercado. Esse processo deve ser capaz de responder a três questões:

- Por que medir?

- O que medir?

- Como medir?

De acordo com os autores, após saber os objetivos do sistema de medição de desempenho ("Por que medir?") e as variáveis básicas do desempenho medido (“O que medir?"), é necessário definir um conjunto de indicadores para operacionalizar a desempenho; em outras palavras, as medidas usadas no sistema de avaliação de desempenho ("Como medir?") (MIRANDA; SILVA, 2002). Estabelecidos e identificados os valores, a missão, o negócio e a estratégia, é preciso saber se a empresa está no caminho certo; para isso, ela precisa medir este caminho. Desta maneira, os 
indicadores devem ser escolhidos precedidos pela escolha da estratégia e da estrutura organizacional (BONELLI et al., 1994).

Os indicadores podem ser centrados em vários focos, dependendo do objetivo do sistema de medição de desempenho adotado pela empresa, voltado para as metas e objetivos da empresa. Uma observação importante e destacada por Johnson e Kaplan (1993) é que nenhuma organização consegue ter vários indicadores ao mesmo tempo. Para os autores, é preciso definir um número de objetivos (metas) num dado período de tempo; caso contrário, perde-se o foco.

Takashina e Flores (1996, p.3-4) apresentam algumas contribuições que os indicadores desempenham nas organizações, tais como:

- estão ligados ao conceito da qualidade centrada nos clientes, isto é, são gerados a partir das necessidades dos clientes;

- possibilitam o desdobramento de metas do negócio na estrutura organizacional para os propósitos da organização;

- estão associados às áreas do negócio nas quais os desempenhos causam maior impacto no sucesso organizacional, isto é, dão suporte à análise crítica dos resultados do negócio, às tomadas de decisões e ao replanejamento;

- viabilizam a busca da melhoria contínua da qualidade dos produtos e processos e da produtividade organizacional, aumentando a satisfação dos clientes, competitividade e sua participação no mercado;

- contribuem para a fundamentação de um argumento, com vistas à tomada de decisão.

Alguns indicadores são considerados por Vaconcellos (1985) como vitais às organizações como participação de mercado, volume de vendas, obsolescência tecnológica, diferenciais mercadológicos, ROI (retorno do investimento), entre outros. No que se refere aos indicadores de desempenho, vários autores prescreveram aspectos a serem considerados pelas organizações (RUMMLER; BRACHE, 1994; PERRIN, 1998; MOREIRA, 1996; MORGAN; STRONG, 2003). Os indicadores de desempenho podem ser considerados como uma medida de desempenho comparativa utilizada para responder a questão: como nós estamos indo? Em primeiro lugar, tem-se que entender quais são as medidas adequadas para se mensurar a efetividade, o sucesso ou a saúde da organização. As questões a serem levantadas são: quais os indicadores que definem o sucesso organizacional? Para uma determinada organização, o que é mais importante: o volume de vendas, a concorrência, o produto ou serviço, os resultados, os recursos 
humanos, a satisfação do cliente, a imagem institucional perante as diversas partes interessadas, seu índice de rentabilidade ou produtividade? (AIDAR, 2003).

Moreira (1996, p. 25-31) esclarece que, para sua eficácia, os indicadores devem possuir quatro qualidades: confiabilidade ("atribuir o mesmo valor a algo invariável que esta sendo medido"); validade ("propriedade de medir aquilo que propôs a se medir"); relevância (utilidade que ele oferece ao usuário); e consistência ("o grau de equilíbrio em relação a um determinado sistema de medidas"). Já as observações feitas por Hronec (1994) indicam as seguintes razões para o uso de indicadores: objetividade na medição, entendimento das prioridades de atuação, definição de papéis e responsabilidades, auto-gerenciamento, entre outras.

Assim, uma maneira de categorizar os indicadores de desempenho é com base na parte interessada a que ele atende (quadro 3.4) e nos exemplos apresentados nos Critérios de Excelência do Prêmio Nacional da Qualidade (FPNQ 2003). 


\begin{tabular}{|c|c|c|c|c|c|c|c|}
\hline CATEGORIAS & Clientes e Mercados & Financeiros & Pessoas & Fornecedores & $\begin{array}{l}\text { Produtos e } \\
\text { Serviços }\end{array}$ & Sociedade & $\begin{array}{c}\text { Apoio e } \\
\text { Organizacional }\end{array}$ \\
\hline $\begin{array}{c}\text { PARTES } \\
\text { INTERESSADAS }\end{array}$ & $\begin{array}{l}\text { Clientes atuais ou } \\
\text { potenciais, finais ou } \\
\text { intermediários } \\
\text { (pessoa física ou } \\
\text { jurídica) }\end{array}$ & Acionistas & $\begin{array}{c}\text { Força de Trabalho - } \\
\text { pessoas contratadas } \\
\text { em período integral } \\
\text { ou parcial, } \\
\text { temporárias, } \\
\text { autônomas e } \\
\text { contratadas de } \\
\text { terceiros que } \\
\text { trabalhem sob a } \\
\text { supervisão direta da } \\
\text { organização }\end{array}$ & $\begin{array}{c}\text { Fornecedores de } \\
\text { materiais, } \\
\text { prestadores de } \\
\text { serviços, } \\
\text { distribuidores, } \\
\text { revendedores, } \\
\text { parceiros, } \\
\text { terceirizados, } \\
\text { contratados, } \\
\text { franquias }\end{array}$ & $\begin{array}{c}\text { Acionistas, gestores } \\
\text { e executivos }\end{array}$ & $\begin{array}{l}\text { Sociedade como um } \\
\text { todo, incluindo } \\
\text { comunidades locais }\end{array}$ & $\begin{array}{l}\text { Clientes internos } \\
\text { gestores e } \\
\text { executivos }\end{array}$ \\
\hline $\begin{array}{l}\text { EXEMPLOS DE } \\
\text { INDICADORES }\end{array}$ & $\begin{array}{l}\text { - Participação no } \\
\text { mercado; } \\
\text { - Percentual de } \\
\text { clientes com imagem } \\
\text { positiva da } \\
\text { organização; } \\
\text { - Índice de Top of } \\
\text { Mind; } \\
\text { - Índice de } \\
\text { fidelização; } \\
\text { - Percentual de } \\
\text { clientes satisfeitos; } \\
\text { - Número de inserções } \\
\text { espontâneas na } \\
\text { mídia; } \\
\text { - Número de } \\
\text { reclamações por total } \\
\text { de unidades vendidas. }\end{array}$ & $\begin{array}{l}\text { - Margem bruta; } \\
\text { - Geração de caixa; } \\
\text { - Vendas; } \\
\text { - Rentabilidade } \\
\text { sobre o patrimônio } \\
\text { líquido; } \\
\text { - Valor Econômico } \\
\text { Agregado; } \\
\text { - Liquidez Corrente; } \\
\text { - Crescimento da } \\
\text { Receita. }\end{array}$ & $\begin{array}{l}\text { - Percentual de } \\
\text { oportunidades } \\
\text { preenchidas } \\
\text { internamente; } \\
\text { - Número de } \\
\text { sugestões dos } \\
\text { funcionários } \\
\text { implementadas; } \\
\text { - Investimento em } \\
\text { treinamento em } \\
\text { relação à receita; } \\
\text { - Horas de } \\
\text { treinamento por } \\
\text { funcionário por ano; } \\
\text { - Freqüência e } \\
\text { gravidade de } \\
\text { acidentes de } \\
\text { trabalho; } \\
\text { - Satisfação das } \\
\text { pessoas (índice de } \\
\text { clima } \\
\text { organizacional); } \\
\text { - Rotatividade dos } \\
\text { funcionários; } \\
\text { - Índice de } \\
\text { Absenteísmo. }\end{array}$ & $\begin{array}{l}\text { - Número de não } \\
\text { conformidades } \\
\text { (levantadas nas } \\
\text { auditorias); } \\
\text { - Índice de } \\
\text { certificação de } \\
\text { fornecedores; } \\
\text { - Tempo de entrega } \\
\text { dos fornecedores; } \\
\text { - Número de } \\
\text { devolução de } \\
\text { produtos para os } \\
\text { fornecedores; } \\
\text { - Nível de defeito } \\
\text { dos produtos } \\
\text { recebidos dos } \\
\text { fornecedores; } \\
\text { - Horas gastas com } \\
\text { programas de } \\
\text { qualificação dos } \\
\text { fornecedores. }\end{array}$ & $\begin{array}{c}\text { - Tempo previsto/ } \\
\text { tempo realizado de } \\
\text { projeto; } \\
\text { - Número de } \\
\text { lançamento de } \\
\text { novos produtos ou } \\
\text { serviços; } \\
\text { - Número de } \\
\text { alterações de } \\
\text { projetos; } \\
\text { - Nível de não } \\
\text { conformidade dos } \\
\text { produtos e } \\
\text { serviços; } \\
\text { - Percentual de } \\
\text { material perdido } \\
\text { (sucateamento); } \\
\text { - Percentual de } \\
\text { trabalho ou } \\
\text { serviço; } \\
\text { - Nível de atraso de } \\
\text { entrega dos } \\
\text { produtos ou } \\
\text { serviços; } \\
\text { - Qualidade do } \\
\text { produto; } \\
\text { - Índices de } \\
\text { produtividade. }\end{array}$ & $\begin{array}{l}\text { - Percentual de } \\
\text { receita investida em } \\
\text { Responsabilidade } \\
\text { Social ou Gestão } \\
\text { Ambiental; } \\
\text { - Não } \\
\text { conformidades } \\
\text { ambientais; } \\
\text { - Custo para } \\
\text { tratamento de } \\
\text { passivos } \\
\text { ambientais; } \\
\text { - Imagem da } \\
\text { organização perante } \\
\text { a comunidade e } \\
\text { sociedade. }\end{array}$ & $\begin{array}{c}\text { - Grau de } \\
\text { cumprimento das } \\
\text { metas } \\
\text { estabelecidas no } \\
\text { planejamento } \\
\text { estratégico; } \\
\text { - Nível de } \\
\text { habilidade de } \\
\text { liderança (obtido } \\
\text { na pesquisa de } \\
\text { clima ou } \\
\text { avaliação } 360^{\circ} \text { ); } \\
\text { - Grau de } \\
\text { satisfação das } \\
\text { pessoas em } \\
\text { relação a } \\
\text { precisão das } \\
\text { informaç̃̃es } \\
\text { disponíveis na } \\
\text { organização; } \\
\text { - Resultados da } \\
\text { auto-avaliação } \\
\text { do sistema de } \\
\text { gestão da } \\
\text { organização. }\end{array}$ \\
\hline
\end{tabular}

Quadro 3.4: Principais Indicadores de Desempenho do PNQ Fonte: Adaptado de Aidar (2003) apud $\mathrm{FPNQ}^{4}$ (2003)

${ }^{4}$ FPNQ. (2003). Critérios de Excelência 2003: o estado da arte da gestão para a excelência do desempenho e aumento da competitividade. FPNQ. 
Avaliar um processo requer a mensuração ou quantificação de um desempenho planejado e do desempenho realizado, com o propósito de serem comparados. Para isso, devem-se estabelecer indicadores de desempenho para identificarem os impactos gerados na empresas. Segundo Andersen (1999), os indicadores podem ter aspecto quantitativo (traduz diretamente os resultados), aspecto qualitativo (retrata os resultados mais subjetivos que precisam de escalas comparativas para serem analisados) e aspecto comportamental (analisa as atitudes e posturas de indivíduos e grupos).

Para Carvalho (1995), um indicador de desempenho deve ser uma forma objetiva de medir a situação real contra um padrão previamente estabelecido. Ainda, ressalta que o indicador só deve fazer sentido e ser utilizado pelo profissional completamente responsável por ele. Desta maneira, Hronec (1994) apresenta algumas razões para a utilização de indicadores:

- Estabelece a compreensão de prioridades de atuação;

- Objetividade de avaliação;

- Profissionalização das decisões;

- Oferece a possibilidade de acompanhamento histórico;

- Define os papéis e responsabilidades;

- Permite o autogerenciamento;

- Muda o comportamento.

Para operacionalizar as medidas que irão avaliar o desempenho, é importante entender sua dimensão estratégica, ou seja, identificar o que ele deve refletir em relação aos fatores estratégicos do negócio, das bases competitivas, das competências e dos métodos essenciais a serem utilizados para o sucesso da organização (ARAÚJO, 2001). Deve-se atentar para o fato de que, para apoiar efetivamente o processo de gestão estratégica, "o indicador de desempenho deve traduzir a estratégia em termos das iniciativas que tragam melhorias operacionais" (ARAÚJO, 2001 p.103). Desta maneira, ele deve privilegiar os critérios de avaliação que motivem e encorajem a organização a realizar os objetivos estratégicos a fim de atender as necessidades dos consumidores (ARAÚJO, 2001). 


\section{ESPECTFCDADES DAS PFQQENASE MÉDIAS EMPRESAS}

Foi a partir da década de 70 que as pequenas e médias empresas (PMEs) começaram a se sobressair na maioria dos países industrializados, aumentando sua contribuição na criação de empregos e ao valor somado das exportações em comparação às grandes empresas. $\mathrm{O}$ desenvolvimento das PMEs ocorrido a partir da década de 70 deve-se ao fato da descentralização e desintegração vertical das grandes empresas e formação de comunidades de pequenas empresas (LOVEMAN; SENGENBERGER, 1990).

Fatores que devem nortear qualquer política governamental, como geração de emprego, renda e desenvolvimento regional são destacados constantemente em jornais, revistas e livros (LIMA, 2001). As pequenas empresas têm merecido a atenção da sociedade: são as grandes responsáveis pela geração de empregos e renda, dado o seu potencial de inovação, principalmente quando estão vinculadas a uma cadeia de suprimentos de peças, componentes e serviços para a grande empresa cliente (AMATO NETO, 2000). As pequenas empresas costumam atuar em firmas prestadoras de serviços, comércio varejista e indústria de pequeno porte e possuem características semelhantes, como número de empregados, capital, faturamento anual, quantidade produzida, tipo de sociedade, entre outras (KOTEY; SLADE, 2005).

As pequenas empresas possuem uma participação significativa na economia brasileira e de outros países, respondendo, no Brasil, por 5,7 milhões de empresas e outras organizações ativas, com inscrição no Cadastro Nacional da Pessoa Jurídica (CNPJ - segmento formal da economia). Deste total, representam 39,6 milhões de pessoas (IBGE- Cadastro Central de Empresas - CEMPRE, 2005) e 99\% das empresas brasileiras de micro e pequeno porte (SOBRAL; PECI, 2008).

Este capítulo apresenta a caracterização de suas especificidades de gestão, bem como a relevância socioeconômica e o uso da medição de desempenho nas pequenas e médias empresas. 


\subsection{CLASSIFICAÇÃO DO PORTE DAS EMPRESAS}

Existem diferenças para definir o porte das empresas, e até hoje não há um critério universal para isso. A diferença de critérios não está presente apenas em nível dos países, mas também dentro de um mesmo país, da região ou dos órgãos que as supervisionam. Ainda, é uma questão problemática dada a diversidade de critérios, condições econômicas e produtivas. O critério é impreciso, sendo marcado por forte heterogeneidade (JULIEN, 1997; OLIVIER; RILEY, 1996; LOVEMAN; SENGENBERGER, 1990). Para Leone (1991), a classificação segundo o porte destacase em virtude de revelar o comportamento econômico e social das PMEs: elas apontam soluções mais lógicas para seus problemas, servem de parâmetro aos programas e as ações governamentais, são de fácil coleta, possibilitam análises comparativas entre empresas, são de uso corrente em todos os setores, entre outros.

\subsubsection{Critérios de Classificação}

O termo "pequena empresa" apresenta diversas classificações. Julien (1998) estabelece seis características com o objetivo de caracterizar a empresa de pequeno porte: o tamanho (baseado no número de funcionários); a gestão centrada no proprietário; o baixo nível de especialização dos dirigentes, equipamentos e funcionários; a estratégia informal ou intuitiva; o sistema de informações simples, informal (funcionários e dirigente) e o sistema de informações externo simples (dirigente e clientes).

O critério para mensurar o porte das empresas mais utilizado no Brasil é a classificação do SEBRAE, que se baseia no setor (industrial e comércio/serviço) e no número de empregados (Quadro 4.1).

\begin{tabular}{|c|c|c|}
\hline PORTE & \multicolumn{2}{|c|}{ EMPREGADOS } \\
\hline & $\begin{array}{c}\text { Comércio e } \\
\text { Serviços }\end{array}$ & Indústria \\
\hline Microempresa & 09 & 19 \\
\hline Pequena Empresa & 10 a 49 & 20 a 99 \\
\hline Média Empresa & 50 a 99 & 100 a 499 \\
\hline Grande Empresa & acima de 100 & Acima de 500 \\
\hline
\end{tabular}

Quadro 4.1: Classificação das Empresas Segundo o Setor e o Número de Empregados Fonte: SEBRAE (2008) 
Para classificar as PMEs pelo porte, também podem ser utilizados critérios qualitativos e quantitativos.

\subsubsection{Critérios Quantitativos}

Os critérios quantitativos relacionam os critérios específicos do setor e estrutura de gestão; são de diversos tipos e refletem diferentes componentes da atividade empresarial (LEONE, 1991). De acordo com Leone (1991), os critérios quantitativos (econômicos) são os predominantes e mais fáceis de manipular. Diferenciam as empresas conforme seu porte, número de funcionários, faturamento, capital investido, entre outros (GONÇALVES; KOPROWSKI, 1995).

O critério quantitativo mais utilizado no Brasil é a classificação segundo o número de funcionário (GONÇALVES; KOPROWSKI, 1995), conforme apresentado no quadro 4.1. Para Leone (1991) esta classificação é um critério tanto econômico quanto social, pois oferece indícios dos problemas sociais pertinentes como nível de renda e produtividade.

Deve-se considerar o faturamento (ou vendas) como um critério quantitativo também utilizado em muitos países. É um critério econômico, que determina o movimento operacional da empresa, ou seja, é um critério contábil. O faturamento é satisfatório porque reflete o tamanho do mercado da empresa, entretanto, perde sua confiabilidade para determinadas finalidades como, por exemplo, para as flutuações da moeda (LEONE, 1991).

\subsubsection{Critérios Qualitativos}

Os critérios qualitativos refletem uma imagem mais fiel da empresa, contemplando a estrutura interna organizacional e os estilos de gestão, ou seja, o dia a dia da empresa. Ajudam a explicar o comportamento social, determinam o porte das empresas e são mais fáceis de coletar, pois permitem medidas de tendências no tempo e análises comparativas (LEONE, 1991).

Enquanto os critérios quantitativos dão uma visão de empresa estática, os critérios qualitativos oferecem uma visão em movimento, de ação gerencial, mostram a empresa em funcionamento (bens materiais e humanos), operando com fornecedores e 
clientes, realizando ações e mostrando a natureza das suas atividades. Como exemplos de critérios qualitativos das pequenas empresas, têm-se: são organizações sem produção em escala; não apresentam mão de obra especializada; usam trabalho próprio ou de familiares; mostram estreita relação pessoal do proprietário com os funcionários, entre outras (LEONE, 1991). Certamente, não se teve a pretensão nem de citar, nem tampouco de analisar todos os critérios qualitativos disponíveis na literatura; eles são descritos posteriormente na seção 4.3 e 4.3.1.

\subsection{MORTALIDADE E SOBREVIVÊNCIA DAS EMPRESAS}

Constada a importância das pequenas empresas, cabe destacar a necessidade de se conhecer a outra face da moeda, ou seja, sua taxa de mortalidade. Mesmo com a característica de flexibilidade, essas empresas encontram dificuldades no mercado, devido à alta competitividade, pois competem com empresas com melhores características estruturais, como as de grande porte. Essas dificuldades contribuem para aumentar o risco e a incerteza, tornando seu gerenciamento uma atividade bastante complexa e desafiante. Dessa maneira, a concorrência reflete no aumento da mortalidade logo nos primeiros anos de vida.

Apesar da importância econômica das pequenas e médias empresas, sua taxa de mortalidade ainda é elevada (MACHADO, 2000; SILVA, 1998). Os resultados apurados pelo SEBRAE/FUBRA (2004a) mostram algumas causas na opinião dos empresários que fizeram parte da pesquisa: falhas gerenciais nas questões do negócio; como falta de capital e planejamento, falta de conhecimentos gerenciais e problemas financeiros; falhas econômicas e conjunturais como falta de clientes, recessão econômica do país e maus pagadores; e, finalmente, a falta de crédito. Cabe destacar, ainda, que outras causas são apontadas pelo SEBRAE/São Paulo (2005) sendo destacada a taxa de mortalidade maior no primeiro ano de vida, chegando a $29 \%$, conforme a figura 4.1. Das empresas paulistas, $56 \%$ fecham até o $5^{\circ}$ ano de atividade. As principais causas do seu fechamento são: comportamento empreendedor pouco desenvolvido; gestão deficiente do negócio; conjuntura econômica deprimida; e problemas pessoais do proprietário. 
Drucker (1981) atribui o maior problema das pequenas e médias empresas à sua pequenez, que não suporta a necessária estrutura administrativa, já que os cargos de cúpula exigem versatilidade superior à dos correspondentes de empresas maiores. Por vez, Longenecker et al. (1997) afirmam que tanto as grandes como as pequenas empresas exigem um processo gerencial, mas, embora esses gerentes desempenhem funções gerenciais semelhantes, seus trabalhos são diferentes, pois existem trabalhos distintivos no gerenciamento da pequena empresa.

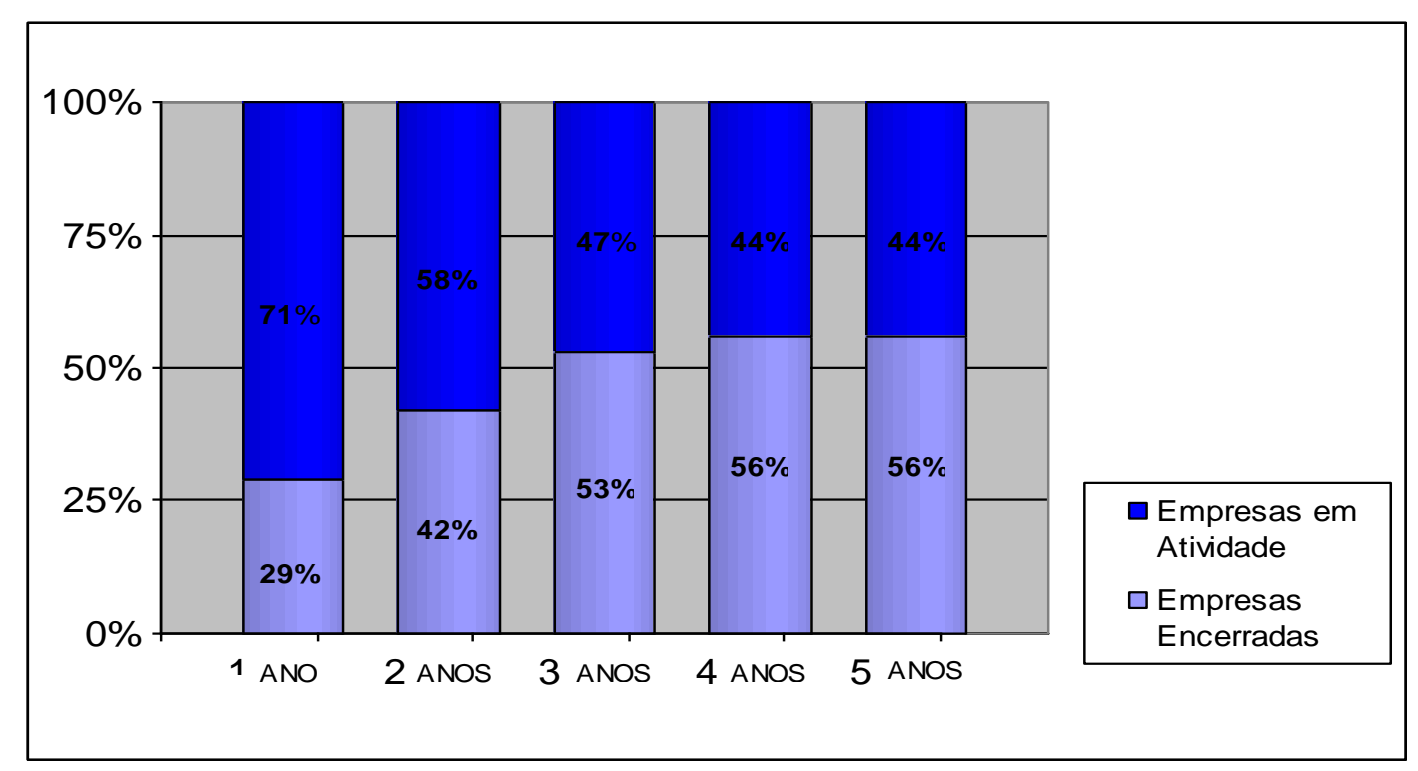

Figura 4.1: Sobrevivência e Mortalidade das Empresas do Estado de São Paulo Fonte: SEBRAE (2005, p.16)

De certo modo, os pequenos negócios estão conseguindo uma sobrevida maior. Há quatro anos, a taxa de mortalidade das empresas com até cinco anos era de $71 \%$, constatando-se, nesse novo estudo feito pelo SEBRAE (2005), que o índice caiu para $56 \%$. Embora ainda alto, sinaliza que os pequenos negócios começam a funcionar. Entre os fatores que contribuíram para essa redução, pode-se destacar o crescimento de políticas de apoio ao segmento como os programas de estímulo ao empreendedorismo junto às prefeituras e câmaras municipais do SEBRAE. Também, se podem considerar abordagens gerenciais e instrumentos administrativos mais eficazes, pois grande parte dos problemas enfrentados resulta de questões estratégicas que, por sua vez, ocasionam outras dificuldades (BORTOLI NETO, 2005).

Em face da velocidade com que ocorrem as mudanças no mundo empresarial, faz-se necessária uma constante atualização, para adequar as informações ao contexto atual (SOUZA et al., 2002). As pequenas e médias empresas, pela sua estrutura 
organizacional e também pela forma como são gerenciadas, são muito vulneráveis às mudanças do ambiente. Para Souza et al. (2002, p.4), quando se trata de pequenas e médias empresas, "a maioria dos empresários se envolve em outras funções dentro da organização. Sua preocupação centra-se apenas no volume de vendas e na lucratividade, não sobrando tempo para a devida apreciação dos relatórios contábeis".

\subsection{ESPECIFICIDADES DE GESTÃO DA PEQUENA EMPRESA}

Durante muito tempo, estudiosos afirmavam que as pequenas e médias empresas deveriam utilizar os mesmos princípios de administração utilizados pelas grandes empresas, só que em menor escala, pois acreditavam que primeiras empresas eram semelhantes às segundas. Em um ambiente extremamente competitivo, algumas especificidades das pequenas e médias empresas são favoráveis como a liderança do proprietário; o otimismo, a dedicação e o esforço pessoal dos dirigentes; o tamanho da empresa, que favorece a agilidade, permitindo a descoberta de oportunidades e nichos de mercado a explorar (OLIVEIRA, 1994).

De acordo com Mintzberg (2003) e Leone (1991), as pequenas empresas apresentam uma estrutura simples, com pouca ou nenhuma estrutura, poucos assessores de apoio; a divisão do trabalho não é rigorosa; há uma diferenciação mínima entre as unidades; a supervisão é direta; as atividades estão centralizadas na cúpula; há uma pequena hierarquia gerencial; usam trabalho próprio ou de familiares; têm uma integração estreita com a comunidade local a que pertencem seus proprietários; não pertencem a grupos financeiros econômicos, e o poder decisório é do executivo principal. Contempla-se ainda que, no âmbito organizacional, seu comportamento é pouco formalizado, e o uso de planejamento e treinamento é mínimo.

Leone $(1991,1999)$ afirma que não é possível definir as pequenas e médias empresas com um único conceito, pois elas não têm o mesmo comportamento econômico e social, mas o aprofundamento no conhecimento de suas especificidades favorece a diminuição da alta taxa de mortalidade. A autora estabelece um agrupamento das especificidades das pequenas e médias empresas em três grupos: organizacionais, decisionais e individuais (Quadro 4.2). 


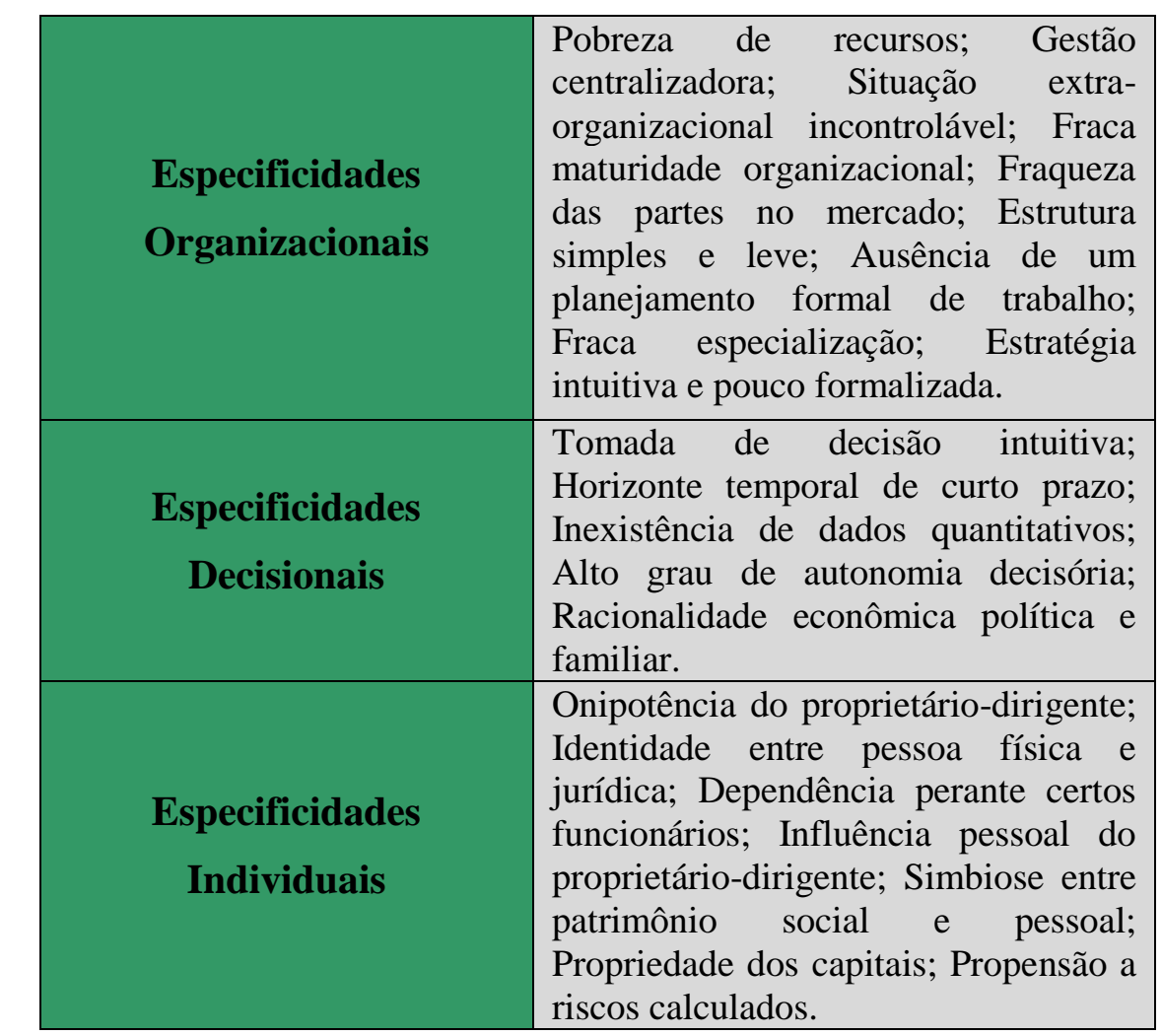

Quadro 4.2: Especificidades Organizacionais, Decisionais e Individuais

Fonte: Leone (1999, p.94)

Convém destacar que há um consenso em se admitir que os objetivos das pequenas empresas confundem-se com os de seus proprietários: sua atitude pode ser uma barreira para o processo estratégico, pois o mesmo confiam na própria experiência e em contatos pessoais ao fazer a coleta de informações estratégicas. Agem de acordo com os seus princípios, intuição, instinto, impulso e se responsabilizam por grande parte das funções, tornando-se escasso o tempo para atividades estratégicas.

De acordo com Terence (2002), as pequenas empresas possuem algumas especificidades que influenciam sua gestão e atuação no mercado. Reis e Escrivão Filho (2005) destacam a informalidade de sua administração, decorrente da ausência de normas e comunicação escritas que atingem principalmente a definição de cargos entre o proprietário (administrador) e os demais colaboradores da empresa, como uma das causas de problemas administrativos relacionados à eficiência.

É importante considerar que existem algumas características que diferenciam as pequenas das médias empresas. Segundo Benze (2008), o dirigente da média empresa que é totalmente centrado nas atividades administrativas, determina os objetivos organizacionais e dirige a empresa, ao contrário dos dirigentes das pequenas empresas 
que, muitas vezes, desempenham quase todas as funções da organização. As atividades nas pequenas empresas são exercidas diferentemente das de médias empresas, pois são executadas de forma acumulativa por poucas pessoas ou até mesmo por uma única pessoa, o empresário. Assim, o executivo é o ator principal na pequena empresa influenciando os comportamentos dos funcionários e o desenvolvimento dela. Normalmente, a maioria das pequenas empresas não possui organograma definido, pois o poder está centralizado no proprietário. No entanto, o que as define são seus recursos limitados. Já as médias empresas possuem uma estrutura mais bem definida e são departamentalizadas de acordo com suas necessidades.

Como mencionado por Rothwell e Dodgson (1993) tanto as pequenas e médias empresas como as grandes apresentam vantagens em gerar e adotar inovações. Para os autores as grandes empresas têm vantagens materiais devido à sua maior capacidade de pesquisa e desenvolvimento, enquanto as pequenas e as médias empresas têm vantagens comportamentais devido à sua maior flexibilidade e adaptação nas mudanças de mercado. Nas pequenas empresas o medo ao risco de inovar é menor e, na maioria das vezes, os funcionários são mais motivados (JULIEN, 1993) e apresentam menor acesso às informações tecnológicas (OECD ${ }^{5}, 1995$ apud LA ROVERE, 1999). Ainda, para Souza (1995, p.797):

\footnotetext{
“Apesar das restrições econômicas e financeiras às quais as pequenas e médias empresas estão submetidas, [...] se acredita que as pequenas empresas são mais ágeis e percebem antecipadamente os sinais de mudanças do que as grandes organizações, sendo, assim, mais flexíveis e adaptáveis".
}

\subsubsection{Estudos sobre as Especificidades}

Muitos trabalhos têm focado as pequenas empresas com o objetivo de entender suas especificidades (LEONE, 1999; ESCRIVÃO FILHO, 1995; WELSH; WHITE, 1981; CARVALHO, 2004; INÁCIO JÚNIOR, 2008). Esses estudos mostram que as especificidades das pequenas empresas exercem forte influência na gestão e fazem com que elas ignorem o planejamento, sendo assim necessária a adequação entre esta técnica e as especificidades delas (ALMEIDA, 1994).

\footnotetext{
${ }^{5}$ Organização para a Cooperação e Desenvolvimento Económico. (1995). Information technology (IT) diffusion policies for small and medium-sized enterprises. Paris: OECD.
} 
Souza (1995) faz referência ao contexto no qual a pequena empresa está inserida. Para a autora, a relação entre a pequena empresa e seu contexto pode ser entendida por meio de dois aspectos: ela pode estar ou não relacionada às estratégias de grandes corporações. Portanto, sua classificação refere-se ao grau com que as pequenas empresas estão subordinadas às decisões de grandes unidades produtivas. Desta forma, Souza (1995) classifica as pequenas empresas em dois grupos:

- Empresas dependentes: complementam direta e indiretamente as funções de grandes empresas, executam atividades que compõem o seu processo produtivo ou fornecem um ou mais componentes para o produto final;

- Empresas independentes: não mantêm nenhum contato com as grandes empresas.

Conforme Gonçalves e Koprowski (1995) e Leone (1999), as características das pequenas e médias empresas são demarcadas pelos seguintes fatores:

- A empresa é de propriedade de um só indivíduo ou de pequenos grupos de pessoas;

- Ela é administrada pelo proprietário principal, é o centro de decisões de forma independente e, pouco especializado;

- Seu capital é financiado, basicamente, pelos proprietários;

- Produz em uma área limitada restrita à sua localização ou à região onde está situada;

- Sua atividade produtiva não ocupa posição de destaque em relação ao mercado;

- Estreita relação pessoal do proprietário com os empregados, clientes e fornecedores.

Uma contribuição em relação às especificidades das pequenas empresas é a classificação feita por Migliato e Escrivão Filho (2004), que envolve um modelo organizacional considerando a inter-relação da empresa com o ambiente com as seguintes especificidades: ambiental; estrutural; estratégica; e tecnológica; decisional; e comportamental, descritas no quadro 4.3.

É claro que existem modelos que evidenciam outros componentes das organizações não abordados no modelo adotado por Migliato e Escrivão Filho (2004, p.7). Para os autores, a questão mais importante no momento:

"Não é a que envolve a escolha deste ao daquele modelo, mas a concepção da idéia de que a pequena empresa e suas especificidades precisam ser enxergadas por uma perspectiva mais abrangente do que aquela que tem sido utilizada até então". 


\begin{tabular}{|c|c|}
\hline Especificidades & Características \\
\hline Ambiental & $\begin{array}{l}\text { Refere-se ao ambiente externo, ou seja, em que a empresa está } \\
\text { inserida e reflete no processo estratégico organizacional. O } \\
\text { ambiente empresarial pode ser dividido em dois componentes: } \\
\text { macroambiente e ambiente setorial. O macroambiente refere-se } \\
\text { às forças políticas, econômicas, sociais, legais e tecnológicas. } \\
\text { Assim, indicam, por exemplo, o poder de negociação no setor em } \\
\text { que atua e o seu grau de dependência com relação às decisões das } \\
\text { grandes corporações (PEREIRA, 1999; MIGLIATO; } \\
\text { ESCRIVÃO FILHO 2004). }\end{array}$ \\
\hline Estrutural & $\begin{array}{l}\text { Refere-se aos aspectos internos, ao modo como as atividades na } \\
\text { pequena empresa são divididas, organizadas e coordenadas. } \\
\text { Como exemplo podem-se citar as relações informais, falta de } \\
\text { recursos e pessoal qualificado e falta de planejamento } \\
\text { (ALMEIDA, 1994; NAKAMURA, 2000, MIGLIATO; } \\
\text { ESCRIVÃO FILHO 2004). }\end{array}$ \\
\hline Estratégica & $\begin{array}{l}\text { Está relacionada à forma de como se desenvolve o processo de } \\
\text { elaboração estratégica. Pode-se citar a classificação de Mintzberg } \\
\text { e Quinn (2001, p.26-32), através de cinco definições, também } \\
\text { caracterizadas como } 5 \text { Ps: a estratégia é um plano; a estratégia é } \\
\text { um padrão; a estratégia é uma posição; ou a estratégia é uma } \\
\text { perspectiva. Dessa forma, elas indicam qual dessas estratégias } \\
\text { tende a ser utilizada pelas pequenas empresas. }\end{array}$ \\
\hline Tecnológica & $\begin{array}{l}\text { Refere-se às tecnologias utilizadas pelas organizações. Muitas } \\
\text { das pequenas empresas utilizam sistemas tecnológicos simples. } \\
\text { Entretanto, devido a suas vantagens comportamentais, dada a sua } \\
\text { maior flexibilidade e adaptação nas mudanças de mercado, } \\
\text { apresentam possibilidades de produzir inovaços. Nas pequenas } \\
\text { empresas o medo ao risco de inovar é menor (JULIEN, 1993; } \\
\text { KRUGLIANSKAS, 1996; DAFT, 1999). }\end{array}$ \\
\hline Decisional & $\begin{array}{l}\text { Refere-se a tomada de decisão. Elas identificam problemas e } \\
\text { oportunidades e, então, os resolvem. Ainda, indicam como os } \\
\text { componentes do processo decisório se desenvolvem nas } \\
\text { pequenas empresas. Muitas vezes nas pequenas empresas, os } \\
\text { dirigentes recusam-se a delegar poderes tornando-se o centro das } \\
\text { decisões, o que caracteriza seu estilo de liderança autocrático e } \\
\text { paternalista (DAFT, 1999; MAXIMIANO, 2004; STONER e } \\
\text { FREEMAN, 1999; MIGLIATO; ESCRIVÃO FILHO, 2004). }\end{array}$ \\
\hline Comportamental & $\begin{array}{l}\text { Está relacionada ao comportamento dos pequenos empresários a } \\
\text { partir da execução de suas atividades. Referem-se às diversas } \\
\text { características atribuídas como gestão centralizadora, } \\
\text { desconhecimento do negócio e das ferramentas administrativas. } \\
\text { Há na literatura diversos modelos de funções gerenciais que } \\
\text { ajuda a compreender melhor o comportamento desses dirigentes. } \\
\text { Filion (1999) retrata dois tipos de dirigentes: os empreendedores } \\
\text { (lidam com o negócio, têm visão de futuro) e os operadores } \\
\text { (lidam com o processo gerencial fundamentado em suas } \\
\text { habilidades pessoais). (MIGLIATO; ESCRIVÃO FILHO, 2004). }\end{array}$ \\
\hline
\end{tabular}

Quadro 4.3: Modelo Organizacional/Especificidades das Pequenas Empresas Fonte: Adaptado de Migliato e Escrivão Filho (2004) 
Ao referir-se ao contexto das pequenas empresas, Gartner (1985), destaca quatro dimensões por meio das quais elas podem ser entendidas: individual, ambiente, processo e organização, que podem ser visualizadas na figura 4.2.

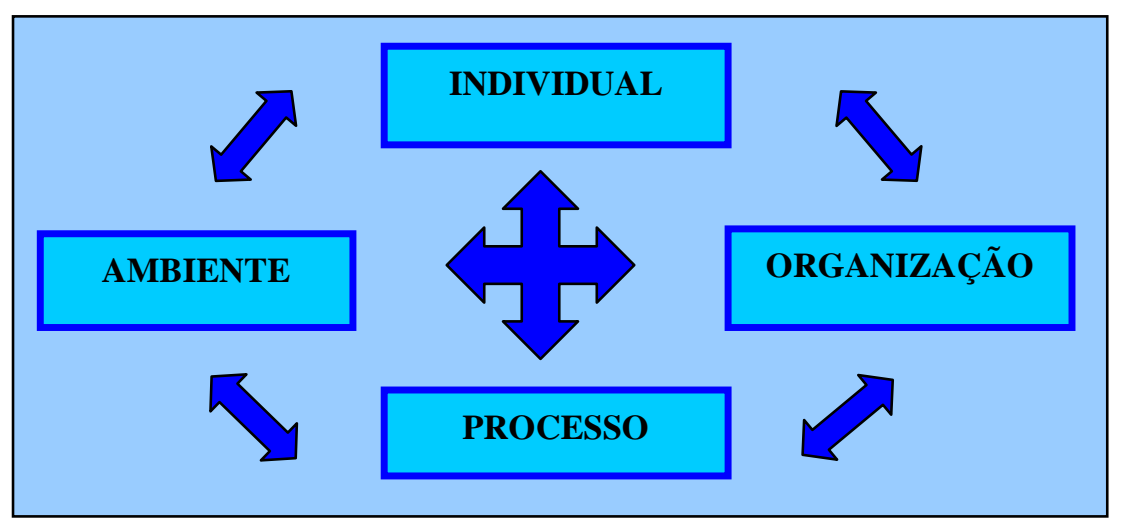

Figura 4.2: Ferramenta para Descrever a Criação de Novas Empresas Fonte: Gartner (1985)

Para o autor, a dimensão individual relaciona-se à pessoa ou ás pessoas envolvidas na criação da empresa. O ambiente relaciona-se à situação que envolve a organização, bem como à influência de outras organizações. Já o processo corresponde às ações que são realizadas pelos indivíduos para iniciar o empreendimento, e a organização, ao tipo de empreendimento que será iniciado.

Após varias reflexões do GEOPE - EESC USP, acredita-se que a pequena empresa seja abordada através de três dimensões. Essas três dimensões objetivam, de maneira segmentada, apresentar as principais características das pequenas empresas.

Dessa maneira, pode-se considerar que a gestão da pequena empresa acontece a partir de algumas especificidades decorrentes de características advindas, principalmente do seu tamanho reduzido (ESCRIVAO FILHO et al., 2005, p. 21).

Para o GEOPE, como nos trabalhos de Nakamura (2000), Motta (2000), Migliato (2004), Albuquerque (2004), Carvalho (2004), Escrivão Filho (2006), Terence (2008), Brito (2008) e Ribeiro (2008), as especificidades da pequena empresa podem ser representadas por meio de um triângulo conforme a figura 4.3 , caracterizada em três categorias:

- Dirigente: que está relacionada com as características pessoais do empresário;

- Organização: que está relacionada com os aspectos internos, decorrentes da divisão do trabalho, departamentalização e interação de pessoas; e 
- Contexto: que está relacionado ao ambiente externo, refletindo no processo estratégico, embora não sejam controláveis pela ação individual dos dirigentes das empresas.

Nesta perspectiva, destacam-se as especificidades de organização, às características do dirigente e do ambiente organizacional das pequenas empresas, conforme especificado abaixo:

- Dirigente: os objetivos das pequenas empresas confundem-se com os de seus proprietários. O administrador age de acordo com os seus princípios, intuição, instinto e impulso. É centralizador, acumula várias funções, tem dependência perante certos funcionários, baixo nível de especialização, pouco ou nenhum conhecimento sobre instrumentos administrativos, exerce diversas atividades e se responsabiliza pela formulação de estratégias (LEONE, 1991; 1999; TERENCE, 2008; ESCRIVÃO FILHO, 1995; CARVALHO, 2004).

- Organização: as pequenas empresas não apresentam uma estrutura administrativa sofisticada, sua estrutura é simples, conferindo-lhes uma menor complexidade vertical (número de níveis de gerência) e horizontal (cargos e departamentos). Elas dependem de valores, objetivos e ambições de seu dirigente; suas atividades estão centralizadas na cúpula. Há uma pequena hierarquia gerencial e o poder de decisões está centralizado no proprietário-dirigente. Ao mesmo tempo, essas especificidades fazem com que elas se caracterizem como organizações com habilidades e funções pouco especializadas, flexíveis, menor grau de formalização e percentual de administradores de topo (TERENCE, 2008; MINTZBERG, 2003).

- Ambiente Organizacional: impõe algumas barreiras às pequenas empresas. O ambiente organizacional apresenta alguns aspectos próprios decorrentes das características do ambiente (tecnológica, social, política, econômica, cultural, legal etc.) Estas características são as especificidades de contexto, como: falta de capital para investimento como em tecnologia; carga tributária elevada (contribui para diminuir seus recursos escassos); falta de informação do empresário sobre o ambiente interno e externo; falta de controle sobre as variáveis do ambiente; carência de apoio de organismos governamentais; carência de treinamento gerencial; dificuldade de acesso a fontes de informações (ALBUQUERQUE, 2004; LEONE, 1999; TERENCE, 2008). 


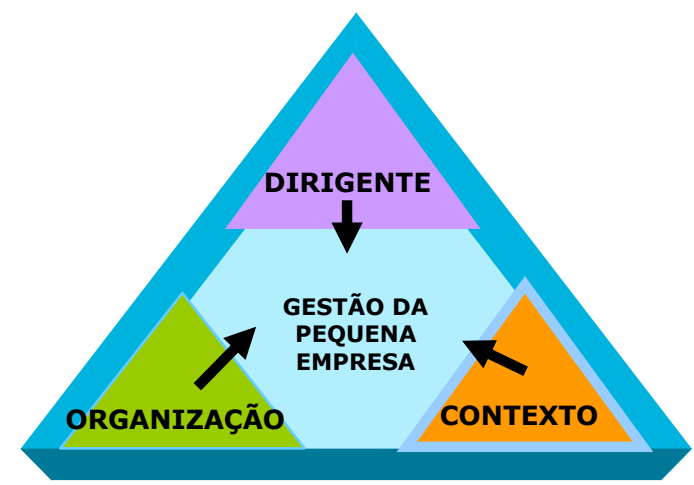

Figura 4.3: Categorias de Especificidades de Gestão da Pequena Empresa Fonte: Adaptado de Terence (2008)

Ainda, a literatura administrativa destaca a simplicidade estrutural destas organizações, sua gestão centralizada e a importância do proprietário-dirigente neste processo (LIMA ${ }^{6}, 1999$ apud TERENCE 2008).

\subsection{MEDIÇÃO DE DESEMPENHO NAS PEQUENAS E MÉDIAS EMPRESAS}

Vários estudos na área da medição de desempenho das PMEs demonstram que ela é uma prática ainda pouco usada, apresenta uma convergência de fatores, e que vários modelos precisam ser adequados a uma nova realidade (OKE et al., 2007; WU, 2006; NEELY et al., 1997; HUDSON; SMART e BOURNE, 2001 ). Uma diferença de grande relevância é que, se as PMEs empresas demorarem a adotar medidas gerenciais eficazes, perderão competitividade e acabarão estagnadas pelos concorrentes.

Devido a fatores organizacionais internos e infra estrutura, por exemplo, as PMEs podem influenciar procedimentos de medição de desempenho (SCASE; GOFFEE, 1984; STOREY, 1994; SHAW; CONWAY, 2000). Como fatores, pode-se também citar a falta de recursos humanos e financeiros (LOVELOCK, 1991; STOREY, 1994; MORRISON, 1998; OGDERS, 1998). Além disso, Welsh e White (1981) identificaram como os principais fatores na diferenciação entre os negócios de pequeno porte e os de grande porte: a informalidade da gestão empresarial; recursos limitados; experiências negativas e as limitações gerenciais; a falta de informações de contabilidade e de computadores; a confiança em um pequeno número de clientes; a

\footnotetext{
${ }^{6}$ LIMA, E. O. (1999). A estratégia emergente na pequena empresa e sua complementaridade à visão estratégia. In: ENCONTRO NACIONAL DOS PROGRAMAS DE PÓS-GRADUAÇÃO EM ADMINISTRAÇÃO, 19, 1999, Foz do Iguaçu. Anais... Rio de Janeiro: ANPAD.
} 
informalidade no processo de tomada de decisão; operação dentro de limites de mercado; falsa concepção de medidas de desempenho, entre outros (OKE et al., 2007; HUDSON et al., 2001; GARENGO et al., 2005; NEELY et al., 1997). Outro resultado interessante são as pesquisas feitas por Beaver et al. (1998) nas quais os autores destacaram as habilidades e ações dos proprietários como influenciadoras do desempenho da organização.

É possível identificar um enorme elenco de obstáculos ao desempenho das pequenas e médias empresas. Entretanto, algumas características das PMEs que promovem a medição de desempenho podem ser citadas como: a gestão é vista por todas as áreas das empresa - devido ao número reduzido de funcionários, todos podem participar do projeto de medição de desempenho; a tomada de decisão é rápida e menos burocratizada; há a necessidade de promover a inovação contínua; falta ou inexistência de informações financeiras; e a necessidade de um diagnóstico da empresa (HUDSON et al., 2001). Ainda, a falta de ambição e visão para aumentar a produção e poder reduzido no setor e no mercado são destacados por Lynch (1999).

As observações de Garengo et al. (2005) e Hudson et al. (2001) sobre suas pesquisas subsequentes indicam que os SMD para PMEs devem ser construídos e voltados para a melhoria contínua, devendo ser usados com facilidade e com um número reduzido de métricas de desempenho. Ainda, Hudson et al. (2001, p.111) sugerem que, quando implantada a medição de desempenho, as PMEs devem focar recursos humanos e financeiros, criar um processo flexível, dinâmico e compatível com suas limitações.

A partir da literatura especializada, são destacadas algumas recomendações para introduzir a prática de medição de desempenho nas PMEs, tais como: basear o projeto de desenvolvimento de SMD em fatores externos e internos de desempenho (WU, 2006); realizar reuniões de brainstorming para os colaboradores discutirem sobre a incorporação da medição de desempenho no dia a dia das pessoas (CARDOZO GALDÁMEZ, 2007); estabelecer um tempo para alcançar melhorias e escolher as métricas de desempenho relacionadas às necessidades da empresa (WILSON; SHEAHAN, 2006; CHANG; MORGAN, 2000); entre outras.

Tem-se a consciência de o número de PMEs que de fato utilizam a medição de desempenho ser limitado (MASSEY, 2004). Os autores identificaram que muitos dos administradores dessas empresas não têm acesso a bibliografias especializadas e, tampouco, a especialistas do assunto. Para muitas dessas empresas, é inviável 
acompanharem as publicações sobre o tema (Wilson; Sheahan, 2006) e há carência de publicações sobre métodos ou modelos de referência que podem ser seguidos (CARDOZO GALDÁMEZ, 2007).

De fato, existem vários fatores que podem influenciar a medição de desempenho nas pequenas e médias empresas, tais como recursos humanos escassos (funcionários desempenham várias funções) e falta de qualificação (os gerentes desconhecem métodos e ferramentas de qualidade). Somente algumas delas conhecem e percebem os benefícios da medição de desempenho e é comun as PMEs não possuírem sistemas formais de gestão para os processos operacionais e gerenciais (GARENGO et al., 2005).

É importante destacar que as pequenas e médias empresas não podem mais se posicionarem somente como um simples elo entre produtos e clientes. Elas precisam questionar seus clientes sobre o que realmente eles querem, de que necessitam e aderir a tais informações para se manter em um mercado competitivo (GARG; CHAN, 1997). 


\section{SETOR DE SERVIÇOS: TURISMO E HOTELARIA}

O presente capítulo apresenta o referencial sobre o Setor de Serviços, bem como sua caracterização e prática administrativa. Na sequência, será discutida a questão do Turismo, um setor de fundamental importância para o desenvolvimento social e econômico de muitos países. Também será analisado o setor hoteleiro, considerado como essencial à infra estrutura da atividade turística, e a importância da Medição de Desempenho nas Empresas Hoteleiras.

\subsection{SETOR DE SERVIÇOS: CONCEITOS E CARACTERIZAÇÃO}

As atividades de serviços apresentaram intenso crescimento ao longo do século XX. As atividades de serviços oferecidas aos clientes ficam mais complexas a cada dia: de um lado os consumidores mais exigentes; do outro, as empresas tentando conquistar vantagens competitivas e equilibrando-se em fatores como custo, qualidade e atendimento (MONTE, 1997).

As atividades de serviços podem ser demonstradas em nossa sociedade pela posição que ocupam na economia, seja pela participação no PIB, seja pela geração de empregos, e pela análise das tendências e transformações que a economia mundial está experimentando. O setor de serviços assume uma importância cada vez maior em a nível mundial. Nos Estados Unidos, ele responde por cerca de $70 \%$ do produto interno bruto e cerca de $80 \%$ de todos os empregos (KOTLER, 2002). No Brasil, 50\% das empresas formais atuam no setor de comércio, $38 \%$ no setor de serviços e $12 \%$ no setor de indústria e construção (SOBRAL; PECI 2008, p.21).

O setor de serviços incorpora uma grande variedade de atividades. Podem-se citar as empresas prestadoras de serviços, fabricantes de bens, instituições do setor público, organizações sem fins lucrativos, entre outras. É um setor com grande crescimento, como nos serviços profissionais de consultoria gerencial e atividades 
ligadas ao lazer, viagem e entretenimento, contribuindo para a produção de riqueza assim para o aumento na geração de empregos (GRONROOS, 1995).

Não se pode afirmar que existem fronteiras entre a administração da produção e a administração de operações, uma vez que a manufatura e os serviços estão bastante relacionados. A manufatura pode aprender com o serviço no atendimento aos clientes e o setor de serviços pode aprender com a manufatura sobre os fabricantes que se sobressaem na produção (GAITHER; FRAZIER, 2001).

Há diferenças substanciais entre a indústria e os serviços. A distinção entre bens e serviços é demonstrada por Stamatis ${ }^{7}$ (1996 apud Mullins, 2004), conforme o quadro 5.1.

\begin{tabular}{|c|c|}
\hline $\begin{array}{c}\text { Operações de serviço centradas nos } \\
\text { bens e na produção }\end{array}$ & $\begin{array}{c}\text { Operações de serviço centradas } \\
\text { no consumidor }\end{array}$ \\
\hline $\begin{array}{l}\text { Consumidor envolvido em pouquíssimos } \\
\text { processos de produção }\end{array}$ & $\begin{array}{l}\text { Consumidor envolvido em muitos } \\
\text { processos de produção }\end{array}$ \\
\hline $\begin{array}{c}\text { Os processos de produção e de entrega são } \\
\text { separados }\end{array}$ & $\begin{array}{c}\text { Os processos de produção e entregas } \\
\text { sobrepõem-se em: } \\
\text { graus variáveis e } \\
\text { podem até ser idênticos }\end{array}$ \\
\hline A Produção é independente do consumo & $\begin{array}{l}\text { A produção é quase sempre simultânea } \\
\text { com o consumo }\end{array}$ \\
\hline $\begin{array}{l}\text { O planejamento do produto está centrado } \\
\text { no cliente, e o planejamento do processo } \\
\text { está centrado no empregado. }\end{array}$ & $\begin{array}{l}\text { Tanto o planejamento do produto quanto o } \\
\text { do processo estão centrados no cliente }\end{array}$ \\
\hline $\begin{array}{l}\text { Os resultados da produção demonstram } \\
\text { menor variabilidade }\end{array}$ & $\begin{array}{l}\text { Os resultados da produção apresentam } \\
\text { maior variabilidade }\end{array}$ \\
\hline $\begin{array}{l}\text { Mais favoráveis ao estabelecimento de } \\
\text { padrões, mensurações, inspeção e controle }\end{array}$ & $\begin{array}{l}\text { Menos favoráveis ao estabelecimento de } \\
\text { padrões, mensurações, inspeção e controle }\end{array}$ \\
\hline Tecnicamente mais complexas & Tecnicamente menos complexas \\
\hline $\begin{array}{l}\text { A relação consumidor - empregado } \\
\text { geralmente não é complexa }\end{array}$ & $\begin{array}{l}\text { A relação consumidor - empregado } \\
\text { geralmente é muito complexa }\end{array}$ \\
\hline $\begin{array}{c}\text { As habilidades técnicas predominam nas } \\
\text { operações }\end{array}$ & $\begin{array}{l}\text { As habilidades interpessoais predominam } \\
\text { nas operações }\end{array}$ \\
\hline O treinamento, é em grande parte, físico & $\begin{array}{c}\text { O treinamento é em grande parte } \\
\text { psicológico }\end{array}$ \\
\hline $\begin{array}{l}\text { A maior parte dos produtores não lida } \\
\text { diretamente com o cliente }\end{array}$ & $\begin{array}{l}\text { A maior parte dos produtores lida } \\
\text { diretamente com o cliente }\end{array}$ \\
\hline $\begin{array}{l}\text { A economia de escala é em geral } \\
\text { prontamente atingível }\end{array}$ & $\begin{array}{l}\text { A economia de escala não é prontamente } \\
\text { atingível }\end{array}$ \\
\hline
\end{tabular}

Quadro 5.1: Distinção entre Bens e Serviços

Fonte: Adaptado de Mullins (2004, p.32)

\footnotetext{
7 STAMATIS, D. H. (1996). Total quality service: principles, practices and implementation. Florida: CRC Press. p.23-24.
} 
No entanto, para Daft (1999), as organizações com tecnologia de serviços (por exemplo, hotéis) diferem das organizações com tecnologia de produção (por exemplo, empresas siderúrgicas) quanto ao fato de o produto e consumo serem simultâneos, ou seja, o cliente e um empregado interagem para que o serviço seja prestado. Outra diferença importante é o produto intangível das empresas de serviço, que necessitam de muitos empregados para atender as necessidades dos clientes, enquanto as empresas de produção de bens tendem a ser densas em capital. Por esse motivo, as operações de serviços devem ser planejadas à medida que os níveis de produção se aproximam da demanda de clientes.

Segundo Parasuraman et al. (1990), a qualidade dos serviços pode ser descrita com base em dez dimensões: tangibilidade, confiabilidade, presteza, competência, cortesia, credibilidade, segurança, acesso, comunicação e entendimento do cliente. Kotler (1998) e Grönroos (1995) apresentam as principais características dos serviços que devem ser consideradas pelas empresas; cada uma dessas características apresenta desafios e exige certas estratégias próprias:

- Intangibilidade: os serviços não podem ser provados ou sentidos antes de sua aquisição, diferentemente dos produtos ou bens;

- Heterogeneidade: os serviços são altamente variáveis porque dependem do local onde são executados e de quem os realiza;

- Inseparabilidade: muitas vezes, os serviços são produzidos e consumidos simultaneamente ou a própria pessoa faz parte deles;

- Perecibilidade: está relacionado ao fato de os serviços não poderem ser estocados.

Contudo, Gianesi et al. (1994) e Grönroos (1995) afirmam que a intangibilidade dos serviços os torna difíceis de avaliação para os gerentes, funcionários e mesmo para os clientes.

O serviço é um fenômeno complexo, com muitos significados, apresentando uma gama de definições. Os serviços são ações colocadas à venda que proporcionem benefícios e satisfações (BESSOM, 1973; FITZSIMMONS; FITZSIMMONS, 2000; LOVELOCK; WRIGTH, 2004; GAITHER; FRAZIER, 2001). Para Grönroos (1995, p. 19) são a "base de diferenciação eficaz entre empresas, e, portanto, uma fonte explorável de vantagem competitiva". Ainda, para o autor:

O serviço "é uma atividade ou uma série de atividades de natureza mais ou menos intangível - que normalmente, mas não necessariamente, acontece durante as interações entre clientes e empregados [...]" (GRONROOS, 1995, p.36). 
Uma empresa pode oferecer seus serviços conforme o tipo de produto fabricado, o tipo de mercado em que atua, além de outros fatores. Todavia, parece claro que a empresa que deixe de se preocupar com os serviços que acompanham seus produtos arrisca-se a ter sua posição competitiva seriamente ameaçada. A preocupação do empresário moderno é a de oferecer sempre serviços e produtos com altos índices de qualidade e bons preços (ARAÚJO, 2001).

\subsubsection{Prática Administrativa no Setor de Serviços}

A qualidade da interação entre o consumidor e os diversos componentes do processo de produção dos serviços é essencial na avaliação da qualidade. Quando o cliente julga ter recebido um serviço que supera suas expectativas, ele considera a sua qualidade superior e se sente inclinado a repetir a experiência (MENDES; TOLEDO, 2002). Entretanto, Hauser e Katz (1998) ressaltam que o uso indevido de métricas pode transformar a organização e não produzir o resultado almejado.

Quando se trata de serviços, os compradores avaliam a sua qualidade através dos resultados (expectativas do cliente ao adquirir o serviço) e através de experiências (são analisadas através da maneira que o fornecedor se relaciona com o cliente durante a transação do serviço). Identificar quais são os critérios que os clientes avaliam no serviço permite à gestão de operações, planejar e organizar os sistemas, de modo a garantir o desempenho nos critérios prioritários (XAVIER, 2005; CHASE; GARVIN, 1989; PARASURAMAN et al., 1990; HAMEL; PRAHALAD, 1991; BERRY; PARASURAMAN, 1992; HAUSER; KATZ, 1998; CARVALHO, 2002).

Como elemento mais importante para o atendimento às necessidades dos clientes de empresas de serviços, Lovelock e Wrigth (2004) enfatizam a interdependência de marketing, operações e recursos humanos. Já Heskett, Sasser e Schlesinger (2002) destacam as empresas que têm foco simultaneamente no mercado e nos aspectos operacionais do negócio.

Embora a tecnologia continue avançando e o progresso técnico tenha trazido inovações e aperfeiçoamentos, o ser humano continua como fator primordial de todo o processo de acolhida do cliente e da própria rentabilidade da empresa (CASTELLI, 2000). Dessa maneira, “as empresas de serviços estão aprendendo que o mais 
importante é a capacidade intelectual, a dedicação dos empregados e a fidelidade dos clientes" (DAFT, 1999, p. 88).

É importante observar que o conhecimento da tecnologia de serviços auxilia os gerentes a alinhar a estratégia, estruturar os processos de administração, que podem ser inteiramente diferentes daqueles de uma tecnologia tradicional ou baseados no produto.

\section{2 TURISMO: CONCEITOS E CARACTERIZAÇÃO}

Muitas são as teorias que procuram explicar as origens do Turismo. De acordo com Lunkes (2004, p.18), desde os tempos primitivos, as viagens sempre fizeram parte da atividade do ser humano, quer seja em busca de comida, quer de abrigo. Lyguory e Gray (1990, p. 2) acreditam que as origens do Turismo estejam na Grécia, onde há relatos de viagens realizadas para a participação nos jogos olímpicos.

O Turismo é uma das atividades que mais crescem e se desenvolvem no setor de serviços no mundo. Ocupa um papel de fundamental importância na economia mundial, contribuindo para a geração de empregos e, consequentemente, aumento do fluxo da circulação de riquezas, ocasionando uma elevação da renda per capita e geração de divisas (CALDAS, 2005; HALL, 1996). Anualmente, gera US\$ 4 trilhões e aproximadamente 280 milhões de empregos em todo o mundo (EMRATUR, 2006). Ainda, a média de empregados do setor é de aproximadamente 6 pessoas (LAGE, 2007b).

Segundo dados do IBGE (2003), o Estado de São Paulo responde por 43,38\% da receita de serviços de turismo no país, sendo líder em pagamentos de salários com $41,28 \%$ do total, e no número de pessoas ocupadas, 35,12\%. Em 2003, o país tinha 352.244 empresas que atuavam em atividade relacionadas ao setor turístico, e o seu faturamento somou $\mathrm{R} \$ 76$ bilhões. Em relação a lucros, pagamentos de salários e impostos, o valor gerado foi de $\mathrm{R} \$ 31,1$ bilhões, o equivalente a 2,2\% de valor adicionado ao PIB (LAGE, 2007b). Ainda, a média de empregados do setor é de aproximadamente 6 pessoas (LAGE, 2007b).

De acordo com A MAIOR... (2007), a indústria do Turismo é a que mais cresce. Composto por um elenco de atividades produtivas, o setor turístico no Brasil vem contribuindo com uma participação de 7\% do PIB nacional, atingindo uma receita cambial da ordem de US\$ 5,8 bilhões e promovendo a geração de mais de 5,5 milhões 
de empregos, com significativos impactos creditados à uma intensa movimentação na economia nacional, fatia que tende a crescer rapidamente. (MTur/EMBRATUR, 2008). Considerando fatores econômicos, humanos, tecnológicos e culturais, o desempenho do turismo mundial apresentou um movimento financeiro superior a US\$ 7 trilhões, um crescimento médio de $4 \%$ ao ano e um fluxo de 924 milhões de viagens internacionais (WTTC, OMT, 2008). Ainda, segundo A MAIOR... (2007), o turismo é o quinto principal produto da balança comercial brasileira, atrás apenas de minério de ferro, petróleo bruto, soja em grãos e automóveis. Atualmente, segundo a OMT (ORGANIZAÇÃO MUNDIAL DO TURISMO), o Brasil é o $36^{\circ}$ principal destino do mundo em número de visitantes e o $39^{\circ}$ em faturamento.

Atualmente, o Turismo é visto como um grande fortalecedor econômico tanto para o país como para qualquer localidade que apresente recursos turísticos que podem ser de ordem natural ou cultural. Embora a ação do governo seja importante na regulação e infraestrutura, são as empresas privadas que dominam. O Turismo representa um conjunto de atividades produtivas, que interessam a todos os setores econômicos de um país ou região, e promove o desenvolvimento e o crescimento regional. É formado por uma poderosa cadeia de empresas: de serviços relativos aos alojamentos (indústria das construções e indústria de transformação), à alimentação e às bebidas (atividade agrícola e atividade alimentícia), aos transportes (indústria de transformação e de consumo energético, além de serviços), às aquisições de produtos locais (artesanato e a indústria do vestuário ou transformação), às visitas e aos divertimentos (serviços).

O Turismo pode ser considerado como uma indústria de serviço ou, um montante de indústrias de serviços fragmentada (OTTO; RITCHIE, 1996; MCINTOSH; GOELDNER; BRENT RICHIE ${ }^{8}, 1995$ apud LERNER; HABER, 2000). De acordo com uma pesquisa realizada pelo IBGE (2003), as atividades características do turismo contemplam: serviços de alimentação; aluguel de automóveis; transporte aquaviários; serviço de alojamento; transporte rodoviário; serviços desportivos e de lazer; agências de viagens; auxiliares de transportes; e transporte aéreo. Dentre essas atividades, as mais significativas foram: os serviços de alimentação $(81,49 \%)$; serviço de alojamento $(6,36 \%)$; e de transporte rodoviário (3,82\%). Juntos, eles representam 91,67\% das empresas pertencentes às atividades características do turismo. Além das atividades

\footnotetext{
${ }^{8}$ McINTOSH, R.W., GOELDNER, C.R.; BRENT RITCHIE, J.R. Tourism: Principles, Practices. Philosophies. New York: Wiley, 1995.
} 
características do turismo, IGNARRA (2002) também apresenta os serviços oferecidos (quadro 5.2).

\begin{tabular}{|c|c|}
\hline TIPOS & SUBTIPOS \\
\hline Meios de Hospedagem & $\begin{array}{l}\text { Hotéis; Motéis; Flats; Pousadas; Pensões; Lodges; } \\
\text { Hospedarias; Albergues; Albergues da Juventude; } \\
\text { Campings; Acontamentos; Colônias de Férias; } \\
\text { Imóveis de Aluguel. }\end{array}$ \\
\hline Alimentação & $\begin{array}{c}\text { Restaurantes; Cafés; Lanchonetes; } \\
\text { Sorveterias/Docerias. }\end{array}$ \\
\hline Agenciamento & Agências Emissivas; Agências Receptivas \\
\hline Transportes Turísticos & Aéreo; Rodoviário; Ferroviário; Aquático \\
\hline $\begin{array}{c}\text { Locação de Veículos e } \\
\text { Equipamentos }\end{array}$ & $\begin{array}{c}\text { Carros; Motos; Bicicletas; Embarcações; } \\
\text { Equipamentos Esportivos }\end{array}$ \\
\hline Eventos & $\begin{array}{c}\text { Organizadores de Eventos; Fornecedores de Produtos } \\
\text { e Serviços. }\end{array}$ \\
\hline Espaços de Eventos & $\begin{array}{l}\text { Centros de Convenções; Buffet; Centros de Feiras; } \\
\text { Áreas de Exposições e Rodeios; Áreas de Eventos } \\
\text { Culturais. }\end{array}$ \\
\hline Entretenimentos & $\begin{array}{l}\text { Bares; Boates; Danceterias; Clubes; Parques de } \\
\text { Diversão, Aquáticos e Temáticos; Boliches; Bilhares; } \\
\text { Campo de Golfe. }\end{array}$ \\
\hline Informação Turística & $\begin{array}{c}\text { Guias/Mapas; Posto de Informação; Jornais e Revistas } \\
\text { Especializadas. }\end{array}$ \\
\hline Passeios & Cavalo; Helicóptero; Barco \\
\hline Comércio Turístico & $\begin{array}{c}\text { Suvenires (lembranças/brindes); Artesanato; Produtos } \\
\text { Típicos. }\end{array}$ \\
\hline
\end{tabular}

Quadro 5.2: Atividades Características do Turismo

Fonte: Adaptado de Ignarra (2002, p.54-55)

O turismo é uma atividade que difere de outras devido a algumas particularidades, tais como: é um bem de consumo imaterial, intangível, abstrato e estático; necessita de clientes no local da produção; há uma simultaneidade espacial e temporal da venda e prestação de serviço com o seu consumo; o consumo do serviço é imediato, ou seja, não é estocado; há heterogeneidade da demanda; sua instabilidade torna difícil medir com precisão a procura por serviços turísticos; enfrenta notável competitividade no mercado (KRIPPENDORF ${ }^{9}, 1980$ apud RUSCHMANN, 2002). Deve-se considerar que o turismo também pode promover a melhoria na qualidade de vida; a distribuição de renda; diminuição de impostos x competitividade; renda aos municípios; geração de empregos e força no produto interno bruto (PIB), conforme LAGE (2000).

\footnotetext{
${ }^{9}$ KRIPPENDORF, J. (1980). Marketing and fremdenverkehr. 2. ed. Berna: 1980, p.50.
} 
Cada instituição tem a sua definição e conceitos; todas são corretas em suas colocações, porém cada uma com sua visão. A insuficiência de definições para o entendimento do turismo deve-se ao fato de ser um fenômeno complexo e estar ligado a quase todos os setores da atividade social humana, manifestando-se conforme movimentos históricos, que interferem em diversos aspectos como no econômico, histórico, cultural, político, entre outros.

Para a OMT (2005), turismo é contemplado como o "deslocamento voluntário e temporário do homem fora de sua residência habitual, por uma razão diferente que a de exercer uma atividade remunerada". Por sua vez, pode ser entendido como o deslocamento das pessoas de sua residência habitual por tempo determinado e não motivadas por razões de exercício profissional assim como de obrigações sociais (IGNARRA, 2002; TRIGO, 1998). É “uma atividade econômica de prestação de serviços" (IGNARRA, 2002, p.59).

A atividade do turismo é uma área abrangente que influencia variados aspectos de uma região, como a cultura, o passado histórico, a natureza e a economia do local.

[...] não se pode menosprezar a importância do fenômeno turístico e sua influência econômica, política e cultural [...] o turismo deixou de ser uma atividade periférica para se tornar agente de destaque na vida cotidiana (TRIGO, 1993, p.62).

Com base nos dados do Banco Central, os gastos de turistas estrangeiros em visita ao Brasil no primeiro trimestre de 2007 somaram US\$ 1,332 bilhão, o que corresponde a um incremento de 9,66\% em relação igual ao período de 2006 que chegou a US\$ 1,215 bilhões (BRASIL, 2007).

Para o Ministério do Turismo, o Plano Nacional de 2007/2010 consta de algumas diretrizes para o desenvolvimento do turismo no Brasil. São elas:

- Desenvolver o produto turístico brasileiro com qualidade, contemplando as diversidades regionais, culturais e naturais;

- Promover o turismo como fator de inclusão social por meio da geração de trabalho e renda e pela inclusão da atividade na pauta de consumo de todos os brasileiros;

- Fomentar a competitividade do produto turístico brasileiro nos mercados nacional e internacional e atrair divisas para o país.

Levando em conta a evolução das receitas internacionais do período 19952000, a OMT projeta um crescimento de mais de 240\% no período 2000-2010. 
São crescentes as atividades de pesquisa, ensino e extensão que buscam aprofundar a reflexão acadêmica sobre a temática do turismo Em particular, o turismo vem se tornando um importante campo de atuação da Engenharia de Produção, especificamente nas áreas de planejamento estratégico, qualidade e logística (LEMOS, 1999; BARRETO, 1991; PETROCCHI, 2002).

Considerando a atividade turística, cabe destacar os componentes que compõem a oferta turística dos lugares, segundo o quadro 5.3.

\begin{tabular}{|c|c|}
\hline FATOR & COMPONENTE \\
\hline Atrações & $\begin{array}{l}\text { Naturais, artificiais, feitas pelo homem, construídas com um } \\
\text { propósito específico, herança ou eventos especiais. }\end{array}$ \\
\hline Acessibilidade & $\begin{array}{l}\begin{array}{l}\text { Sistema de transportes composto por rotas, terminais e } \\
\text { veículos. }\end{array} \\
\end{array}$ \\
\hline Amenidades & $\begin{array}{l}\text { Acomodações, alimentação, lojas de varejo e outros serviços } \\
\text { turísticos. }\end{array}$ \\
\hline Pacotes & Pacotes pré-formatados por operadoras e agências. \\
\hline Atividades & $\begin{array}{c}\text { Conjunto de atividades disponíveis no lugar turístico e que os } \\
\text { turistas farão durante sua estada }\end{array}$ \\
\hline $\begin{array}{c}\text { Serviços } \\
\text { auxiliares }\end{array}$ & $\begin{array}{l}\text { Serviços utilizados pelos turistas: bancos, telecomunicações, } \\
\text { correios, agências de notícias, hospitais e outros. }\end{array}$ \\
\hline
\end{tabular}

\subsection{A EMPRESA HOTELEIRA}

Janeiro $^{10}$ (1991) apud Serson (2000) afirma que a história da hotelaria é uma das mais antigas atividades humanas que surgiu por volta do século IV a.C. e tinha por objetivo prestar serviços correspondentes a abrigo e alimentação. A empresa hoteleira teve um grande crescimento após a Primeira Guerra Mundial, num contexto em que a Revolução Industrial já se consolidava e também após a Segunda Revolução Industrial. Entre as razões para o aparecimento da hotelaria foi o comércio de bens e serviços entre regiões distintas, ou seja, a demanda específica por hospedagem classificada como demanda provocada por viagens de negócios. Nos anos seguintes, a evolução foi rápida

\footnotetext{
10 JANEIRO, J. A. (1991). Guia técnico de hotelaria: a arte e a ciência dos modernos serviços de restauração. Lisboa: Cetop.
} 
e constante, gerando o que se conhece como "empresa" ou "indústria" hoteleira, cheia de peculiaridades e caracterizada pela constante necessidade de mudanças.

A empresa hoteleira constitui-se hoje como um setor essencial à infraestrutura da atividade turística. É um subsistema do sistema turístico (PETROCCHI, 2002), uma empresa de serviços que possui suas próprias características (SAAB; DAEMON, 2001). Atualmente, o parque hoteleiro nacional possui aproximadamente 25 mil meios de hospedagem, e, deste universo, 18 mil são hotéis e pousadas. No geral, $70 \%$ são empreendimentos de pequeno porte. Isso representa mais de um milhão de empregos e a oferta de aproximadamente um milhão de apartamentos em todo o país. Estima-se que a hotelaria nacional tenha um faturamento da ordem de U\$ 2 bilhões de dólares ano (ABIH, 2007).

De acordo com a ABIH (2007), o setor hoteleiro possui um patrimônio de $\mathrm{R} \$$ 78,7 bilhões, gasta em média $\mathrm{R} \$ 2$ bilhões por ano com mão de obra e mais de $\mathrm{R} \$ 30$ milhões em contribuições ao Financiamento da Securidade Social (Cofins). Historicamente, segundo a ABIH Nacional, os hotéis investem cerda de US\$ 50 milhões por ano somente para manter o setor.

Segundo dados do IBGE (2007), foram identificadas 10.038 empresas de médio e grande porte nas atividades ligadas ao turismo (2,8\% do total), que tiveram $\mathrm{R} \$$ 56,0 bilhões de receita operacional líquida (73,7\% do total estimado). As médias e grandes empresas ligadas ao turismo também tiveram participação relevante na geração de emprego, sendo responsáveis por $824.062,39,4 \%$ do total. As empresas de maior porte pagaram, em 2003, $\mathrm{R} \$ 9,8$ bilhões, $64,2 \%$ do total de salários e outras remunerações nas atividades ligadas ao turismo. Vale ressaltar que número de empreendimentos aliados a cadeias hoteleiras ainda é pequeno no Brasil. São 9\% em número de hotéis, mas em número de apartamentos é mais representativo, $27 \%$ do total disponíveis (HOTEL INVESTMENT ADVISORS - HIA, 2006).

A empresa hoteleira constitui-se hoje como um setor essencial à infraestrutura da atividade turística. Geradora de empregos, é particularmente relevante em regiões com poucas alternativas de trabalho, fazendo que contribuam para o desenvolvimento regional (MEDLIK; INGRAM, 2000).

No turismo, metade dos gastos refere-se à hotelaria, e entre 60 e $75 \%$ dos gastos locais dos turistas estão ligados a despesas de alimentação e hospedagem, constituindo-se a empresa hoteleira um dos alicerces do turismo, um dos elementos principais que compõem o produto turístico (DIAS, 1990). 
Deve-se considerar que em uma empresa hoteleira, o serviço tem de adicionar valor para o hóspede, ou seja, satisfazer suas necessidades, porque é ele quem pagará à firma um valor maior do que o custo para provê-lo. Por isso, a gestão não pode perder a perspectiva de assegurar serviços diários a preços que garantam seu retorno, para que a organização os possa produzir e distribuir.

\subsubsection{Caracterização do Setor Hoteleiro}

Os hotéis são importantes componentes da indústria do lazer e do turismo. La Torre (2001, p. 29) apresenta um conceito simples sobre hotel que serve para limitar a idéia geral contida nos serviços prestados pela hotelaria: "uma instituição de caráter público que oferece ao viajante alojamento, alimentação e bebida, bem como entretenimento, e que opera com a finalidade de obter lucro”. Medlik e Ingram (2000) acreditam que os hotéis realizam uma importante função nos países, pois fornecem facilidades para a transação de negócios, recreação e entretenimento, são importantes fontes de empregos e centros de comércio para produtos de outras indústrias. Partindo da significância de representatividade. Marques (2003) esclarece que um hotel deve proporcionar aos hóspedes necessidades de sono e descanso, alimentação, distração, entretenimento e contato com o exterior quando necessário. Ainda, deve assegurar estruturas para atender às necessidades dos clientes, como quartos, cozinha e restaurante, bar, salões, piscinas, portaria e telefones. La Torre (2001) esclarece também que essas instituições podem funcionar tanto de forma independente quanto em rede.

Outra importante significância da indústria hoteleira é que ela caracteriza-se pelo seu alto nível de competitividade, devido ao grande número de concorrentes, à contínua introdução de novos produtos e serviços, e ao acesso a diferentes canais de produção. Entre algumas conceituações sobre a empresa hoteleira, Castelli (2000, p. 56) diz que ela pode ser contemplada como uma "organização que, mediante o pagamento de diárias, oferece alojamento a clientela indiscriminada”. Ainda, considera-se empresa hoteleira a pessoa jurídica que explore ou exerce o meio de hospedagem e que tenha como objetivos sociais o exercício da atividade hoteleira (BRASIL, 2002, p. 2).

É importante observar que hotéis são empreendimentos que diferem de outros empreendimentos, devido à intensa participação de serviços e equipamentos na composição de seus custos operacionais, à formatação das receitas e à sazonalidade 
anual. Eles estão, cada vez mais, atraindo a presença e o consumo de residentes dos locais onde se localizam, através da gastronomia (restaurantes), do entretenimento (shows e espetáculos) e de eventos (reuniões de negócios, seminários, congressos, convenções, etc.), com isso criando e ampliando alternativas principalmente em períodos de baixa temporada.

\subsubsection{Classificação dos Meios de Hospedagem}

A indústria hoteleira nacional tem convivido com diferentes sistemas de classificação, que surgiram em virtude da velocidade das transformações enfrentadas pelo setor. As variações não são entre regiões e localizações geográficas, mas também dentro de uma mesma categoria de hotéis em regiões geográficas específicas e qualidade de administração. De certo modo, o método de classificação que hoje prevalece é o da autoclassificação, cabendo ao próprio estabelecimento o preenchimento de um manual de cadastramento e qualificação de hotéis, que dimensiona e avalia qual a sua categoria: superior, turística, econômica, entre outras.

A classificação também é definida de acordo com o padrão de serviços e instalações; com a sua localização; com o porte; quanto à propriedade; quanto às cadeias de hotéis; ou conforme o propósito a que se destina (MARQUES, 2003; VALLEN; VALLEN, 2003). Sigaw, Enz e Namasivayam (2000) classificam a indústria hoteleira baseada em segmento (parcela do mercado a ser atendida - preço baixo, econômico, preço médio, preço alto e luxo), complexidade (número de $\mathrm{UH}$ ), afiliação (participação em cadeia ou rede) e tipo (acomodação - all suíte, estadia prolongada, hotel-convenção, hotel-cassino, centro de convenções, condomínios, padrão, motel, bedand-breakfast). Ainda assim, o padrão de classificação dentro de cada categoria varia de autor para autor e de país para país.

A OMT, internacionalmente conhecida como WTO (LAWSON, 2003), também adota o sistema de classificação por estrelas, que apresenta as seguintes características:

- Uma estrela: hotéis com decoração simples e equipamentos básicos. Garantem uma acomodação confortável e serviços de refeições limitados. Inclui pequenos hotéis privados; 
- Duas estrelas: o padrão de acomodação e oferta de serviços são um pouco mais elevados. Promove melhores níveis de conforto. Compõem-se de hotéis privados e acomodações de baixo custo;

- Três estrelas: hotéis bem recomendados. A acomodação é espaçosa e muito confortável, sendo a maioria dos apartamentos suítes. Oferecem todas as refeições e alguns recursos são disponíveis;

- Quatro estrelas: oferecem elevada qualidade, são bem equipados e mobiliados segundo altíssimos padrões de conforto. Oferecem uma variedade de serviços e recursos;

- Cinco estrelas: oferecem acomodação e mobiliário de excepcional qualidade segundo os mais elevados padrões internacionais de luxo. Prestam serviços impecáveis e oferecem os mais amplos recursos.

Pode-se observar no quadro 5.4 apresentado em parceria entre a Agência Hotel On Line e ABIH (2006) o relacionamento do "preço da diária" (ligado aos serviços e infraestrutura oferecidos pelos estabelecimentos) com o número de estrelas.

\begin{tabular}{|c|c|}
\hline $\begin{array}{c}\text { REFERENCIAL DE } \\
\text { TARIFA }\end{array}$ & $\begin{array}{c}\text { CLASSIFICAÇÃO } \\
\text { EMBRATUR/ABIH }\end{array}$ \\
\hline Até $R \$ 49,99$ & 1 Estrela ou Não classificado \\
\hline De $R \$ 50,00$ até $R \$ 99,99$ & 1 ou 2 Estrelas \\
\hline De $R \$ 100,00$ até $R \$ 149,99$ & 2 ou 3 Estrelas \\
\hline De $R \$ 150,00$ até $R \$ 199,99$ & 3 ou 4 Estrelas \\
\hline De $R \$ 200,00$ até $R \$ 299,99$ & 4 Estrelas ou 4 Estrelas Plus \\
\hline Acima de $R \$ 300,00$ & 4 Estrelas Plus ou 5 Estrelas \\
\hline
\end{tabular}

Quadro 5.4: Relacionamento do Preço da Diária x Número de Estrelas Fonte: Adaptado Agência Hotel On Line (2006)

Ainda, com relação à classificação dos hotéis, Bressolin (2001, p. 37) destaca: quanto ao tipo de hospedagem oferecida (com ou sem alimentação); quanto à categoria das instalações (de luxo a simples); quanto à finalidade (lazer ou comerciais); quanto ao objetivo (sem especificidade ou pertencente a uma estrutura complexa de lazer dirigida a um público-alvo) e quanto à sua operação (contínua ou de temporada, pertencentes ou não a redes hoteleiras).

No Brasil, a classificação é regulamentada pela Embratur. O primeiro sistema de classificação adotado pela Embratur seguiu os padrões da OMT: a simbologia das estrelas, de uma a cinco. Contudo, em 1996, através da Deliberação Normativa nº. 360, sua diretoria decidiu cancelar o então "Sistema Brasileiro de Classificação e Meios de 
Hospedagem e Turismo", justificando que o modelo possuía baixa credibilidade e já estava ultrapassado. Assim, um novo sistema foi oficializado pela Brasil/Mtur (2002), sem, contudo, ter sido efetivamente adotado na hotelaria, apresentado no quadro 5.5. Fantini (2004) argumenta que, através da realização algumas avaliações, ficou evidente que a subjetividade do método continuava a comprometer as metas propostas.

\begin{tabular}{|c|c|}
\hline CATEGORIA & SÍMBOLO \\
\hline Luxo Superior & $* * * *$ \\
\hline Luxo & $* * * *$ \\
\hline Standard Superior & $* * *$ \\
\hline Standard & $* *$ \\
\hline Simples & $*$ \\
\hline
\end{tabular}

Quadro 5.5: Categorias de Meios de Hospedagem de Turismo

Fonte: Ministério do Turismo (2003)

Duarte (1996) e Castelli (2000) também classificam os hotéis quanto ao tamanho, com base no número de unidades habitacionais (UH), quartos e/ou apartamentos de que dispõem, como mostrado no quadro 5.6. Contudo, Castelli (2000) leva em conta ainda o tipo de apartamento, o número de leitos ou a receita anual. Dessa maneira, podem ser considerados por alguns critérios de classificação, como: o local referente ao tamanho da cidade, e a posição referente ao bairro; o propósito da estada por exemplo, hotéis para negócios, convenções ou para férias; a variedade de instalações e serviços e o tamanho do hotel - por exemplo, número de apartamentos e numero de funcionários.

\begin{tabular}{|c|c|}
\hline PORTE & NÚMERO DE UH \\
\hline Hotel Pequeno Porte & 1 a 40 \\
\hline Hotel Médio Porte & 41 a 200 \\
\hline Hotel Grande Porte & Mais de 200 \\
\hline
\end{tabular}

Quadro 5.6: Classificação Quanto ao Tamanho do Hotel Fonte: Duarte (1996)

Partindo de que há vários tipos de hotéis, maneiras diferentes de distingui-los e classificá-los, as empresas de hospedagem podem ser subdivididas em: hotéis, motéis, pensões, pousadas, hotéis-apartamentos, centro de férias, albergues da juventude, 
camping, entre outros (CASTELLI, 2000). Segundo dados da Agência Hotel On Line (2006), também podem-se destacar as empresas de hospedagem conforma o quadro 5.7.

\begin{tabular}{|c|c|}
\hline CLASSIFICAÇÃO & CARACTERIZAÇÃOO \\
\hline Hotel & $\begin{array}{l}\text { Localizados nas principais vias de acesso dos centros } \\
\text { urbanos. São voltados para hospedagem de curta duração. } \\
\text { Têm serviços de quarto } 24 \text { horas, lavanderia e recepçâo. }\end{array}$ \\
\hline Hotel de Turismo & $\begin{array}{l}\text { Também conhecidos como hotéis de negócios, estão } \\
\text { geralmente localizados em regiões urbanas, destinados à } \\
\text { hospedagem de turistas de lazer ou de negócios (abrange } \\
\text { a área de eventos e de executivos em viagens de } \\
\text { negócios). É responsável pela maior lucratividade dos } \\
\text { estabelecimentos localizados nos grandes centros } \\
\text { urbanos. }\end{array}$ \\
\hline Hotel de Lazer ou Resort & $\begin{array}{l}\text { Localizados em regiões turísticas, que oferecem atrações } \\
\text { naturais, culturais e históricas, e que apresentam infra- } \\
\text { estrutura para o lazer do turista. Dispõem de serviços } \\
\text { hoteleiros em geral, com sala, dormitório, banheiro e } \\
\text { cozinha americana. São estabelecimentos que } \\
\text { comercializam bem-estar. Também costuma oferecer } \\
\text { infraestrutura para eventos, garantindo parte de seu } \\
\text { faturamento na exploração de segmento de negócios. } \\
\text { Normalmente são afiliados a redes hoteleiras. }\end{array}$ \\
\hline $\begin{array}{c}\text { Flat, Apart-Hotel ou } \\
\text { Residence }\end{array}$ & $\begin{array}{l}\text { São destinados a viajantes que pretendem ficar por um } \\
\text { longo período em determinada região, geralmente acima } \\
\text { de } 30 \text { dias. A grande maioria é localizada nos centros } \\
\text { urbanos e oferece apartamentos imobilizados e } \\
\text { equipados, proporcionando ao morador o conforto de } \\
\text { uma residência. É como um imóvel comercial para } \\
\text { locação, com custo baixo. São concorrentes diretos dos } \\
\text { hotéis. }\end{array}$ \\
\hline Pousada ou Hospedaria & $\begin{array}{l}\text { São estabelecimentos de pequeno porte, geralmente } \\
\text { familiares e administradas pelos proprietários, constitui- } \\
\text { se normalmente por grandes casas ou chalés. Estão } \\
\text { localizadas em regiões turísticas. }\end{array}$ \\
\hline
\end{tabular}

Quadro 5.7: Classificação/Tipo de Meios de Hospedagem

Fonte: Adaptado de Hotel On Line (2006); Gorini e Mendes (2005); Saab e Gimenez (2001)

Ainda, encontram-se classificações mais diversas, como as apresentadas por Marques (2003): hotéis de cidade (de centro e de periferia, destinados a clientes em viagens de negócios, congressos e seminários), hotéis de aeroporto (recebem passageiros em trânsito, com permanência muito curta), hotéis de veraneio (funcionam somente nas estações de inverno ou verão), hotéis termais ou de cura (servem de apoio às termas), hotéis de rodovia ou motéis (recebem normalmente motoristas em viagem durante uma noite), hotéis das estações balneárias (localizados em praias ou locais de 
veraneio), hotéis residenciais (oferecem estrutura de quarto e café da manhã), pensões (locais simples com estrutura familiar, que oferecem alojamento e, às vezes, refeições).

Verifica-se a existência de diversas empresas e órgãos especializados no setor de classificações próprias para a realização de suas análises. Deve-se atentar que, nos hotéis pertencentes a redes hoteleiras, a marca identifica tudo, desde o padrão de instalações até os serviços oferecidos; as classificações tradicionais acabam perdendo a sua importância como elemento identificador de cada estabelecimento (GORINI; MENDES, 2005).

É importante observar que, à medida que o Turismo se consolida no cenário mundial, órgãos internacionais passam a debater uma equiparação internacional das categorias dos estabelecimentos hoteleiros, com o intuito de "possibilitar ao cliente a escolha antecipada do tipo e categoria do estabelecimento que deseja consumir" (CASTELLI, 2000, p. 40).

\subsubsection{Prática Administrativa Hoteleira}

As empresas hoteleiras podem ser caracterizadas intensivas em capital de giro. Os recursos são essenciais para financiar os hóspedes, pois só efetuam o pagamento no final do período de estadia. Durante os períodos de baixa temporada, esses empreendimentos necessitam de recursos para cobertura dos custos fixos (ANÁLISE setorial, 1999), embora esta necessidade seja proporcional ao seu porte, e dependa das características do estabelecimento e do segmento de demanda explorado.

A empresa hoteleira apresenta alguns problemas como administração e mão de obra pouco especializada, estrutura desbalanceada na oferta de unidades hoteleiras (UH), carência de sistemas de informações de mercado e ausência de planejamento estratégico setorial (SAAB; DAEMON, 2001). Entretanto, algumas ações podem ser iniciadas e ter continuidade, como: investimentos em capacitação profissional, visando ao aprimoramento da administração dos hotéis e à melhoria de qualidade dos serviços prestados; investimentos na modernização dos equipamentos turísticos existentes, buscando padrões de qualidade internacionais; e, finalmente, ofertas estratificadas de alojamentos e de serviços diferenciados, de modo a tornar os empreendimentos hoteleiros mais competitivos (SAAB; DAEMON, 2001). 
Em termos operacionais, Carvalho (2000) argumenta que uma das maiores falhas encontradas no sistema de gestão das empresas hoteleiras situa-se no setor de vendas e de reservas. A autora destaca a ausência de uma pasta de venda que tenha todos os serviços e preços do hotel. Como forma de exterminar essas falhas, propõe um programa de desenvolvimento de produto (identificação de clientes internos e externos) política de promoção e marketing (envolvendo relações públicas, promoções e propaganda).

Os serviços hoteleiros são intensivos em mão de obra, a maior parte das atividades referindo-se ao atendimento aos hóspedes, o que demanda boa qualificação pessoal, a fim de garantir a qualidade dos serviços prestados no empreendimento.

Particularmente nas cidades estudadas (Águas de São Pedro, Analândia, Brotas, Charqueada, Corumbataí, Itirapina, Ipeúna, Piracaia, Rio Claro, Santa Cruz da Conceição, Santa Maria da Serra, São Carlos, São Pedro e Torrinha), foco da presente pesquisa, a divulgação intensiva das cidades, os esforços do município e órgãos ligados ao turismo têm sido evidentes. Mas fazer hotelaria envolve mais do que oferecer cidade limpa, comidas regionais ou hospedagem. Envolve na realidade, gente que presta serviços, desde os carregadores até o telefonista do hotel ou pousada, o recepcionista, camareiras, arrumadeiras, garçons, taxistas, enfim, todos os que entram em contato direto com o hóspede. Saber receber, saber prestar informações, saber responder aos questionamentos dos visitantes, estar atualizado com as informações imprescindíveis para que o hóspede se sinta bem acolhido é de relevante importância. E isso implica envolvimento maior do empregado com a empresa da qual participa: saber quem é a empresa, aonde ela quer chegar, qual o papel dele como empregado na organização, como ele pode colaborar para que ela seja cada vez mais excelente. A satisfação do hóspede é o ponto fundamental para o sucesso de um hotel, sendo essa avaliada através do retorno do hóspede ao estabelecimento. É necessário que esse leve boas opiniões sobre os serviços e atividades oferecidos. O retorno dos hóspedes fiéis e a divulgação do empreendimento visitado ajudam na tarefa de aumentar a demanda. Entretanto, algumas oportunidades para os hotéis garantirem sua continuidade são destacadas por Franco e Noriega (2000, p. 35), como o fornecimento de serviços a grupos adicionais de clientes, lançando novos mercados ou segmentos e expandindo a linha de produtos. Confirma-se, assim, que, para competir no mercado e, principalmente, fortalecer o seu posicionamento estratégico, os hotéis devem optar por oferecer seus produtos/ou 
serviços por baixo custo (menores preços do mercado), por diferenciação (melhor serviço) ou por focalização (atendimento personalizado).

Vale ressaltar que os pequenos empreendimentos hoteleiros representam o momento para o setor hoteleiro, na captação de uma parcela significativa de demandantes das grandes cadeias de hotéis (CARVALHO, 2000).

\subsection{MEDIÇÃO DE DESEMPENHO NA HOTELARIA}

Com o aumento da competitividade, a disponibilidade de informações e novas tecnologias, as empresas estão centralizando esforços para sua gestão e operações estratégicas, com o intuito de atender um mercado cada vez mais exigente. É necessário ficar atento aos requisitos de satisfação dos clientes. Dessa maneira, as empresas precisam desenvolve instrumentos de medição que colaborem com o processo de tomada de decisões, avaliando sua eficácia e eficiência, assim como sua abrangência e consistência (SINK; TUTTLE, 1989).

Para a implantação da medição de desempenho nas empresas hoteleiras, devese, em primeiro lugar, entender claramente quais são as medidas adequadas para se mensurar a efetividade, o sucesso ou a saúde da organização. Como questões a serem levantadas pela organização, por exemplo: quais os indicadores que definem o sucesso organizacional? Para a organização, o que é mais importante: o volume de vendas, a satisfação do cliente, a imagem institucional perante as diversas partes interessadas, seu índice de rentabilidade ou produtividade? Um segundo ponto a ser considerado é a correlação dos indicadores de desempenho, como: a melhoria do clima organizacional (satisfação dos funcionários) influencia a satisfação dos clientes, que por sua vez afeta o nível de vendas? (AIDAR, 2003).

Celestino (2003) apresenta o resultado de uma pesquisa a respeito da utilização de indicadores financeiros e não-financeiros, sob a ótica do Balanced Scorecard, na gestão dos hotéis do Rio Grande do Norte. O autor diagnosticou a utilização de diversos indicadores de desempenho tais como gestão da qualidade total, redução de custos/melhoria de produtividade, retenção-captação-satisfação e lucratividade de clientes, qualidade e custo do processo, capacidades dos funcionários, sistemas de informação, motivação, entre outros. Leite (2004) também apresenta o resultado de sua pesquisa sobre a medição de desempenho em sessenta e duas pequenas empresas 
hoteleiras do Nordeste brasileiro. A autora constatou que os participantes do processo de produção, transformação e comunicação das informações de desempenho, são principalmente os clientes, e posteriormente os empregados.

Machado, Veras Machado e Holanda (2006) realizaram uma pesquisa no setor hoteleiro da Cidade de João Pessoa/PB em 31 hotéis, dos quais dezoito são pequenos, seis médios e cinco grandes para averiguar a utilidade da medição de desempenho. Com a pesquisa, concluíram desta forma que os hotéis pesquisados não utilizam modelos formais de medição de desempenho; priorizam a perspectiva dos clientes; nem todos os entrevistados conhecem a importância e fazem a medição de desempenho; aqueles que medem o desempenho não fazem uso de modelos formais de medição de desempenho; priorizam os indicadores não-financeiros, uma vez que todos utilizam pelos menos uma medida não-financeira para medição de desempenho; os indicadores mais utilizados são a taxa média de ocupação, qualidade dos serviços, fidelidade do cliente e evolução do número de clientes.

Uma pesquisa realizada por Araújo (2001) apontou a diária média como principal indicador de medição hoteleiro, enquanto uma pesquisa realizada pela FOHB (2006) apontou a taxa de ocupação e a receita por apartamento disponível (ou REVPAR, do inglês per available room).

A medição de desempenho em hotéis deve identificar preços compatíveis com a qualidade oferecida pelos seus concorrentes e serviços cada vez melhores. É preciso conhecer através de indicadores de desempenho o perfil de seus hóspedes e suas reais necessidades, com base em sistemas de medição de desempenho para alcançar posição de destaque nesse ambiente competitivo. Assim, indicadores de desempenho já utilizados na hotelaria podem ser visualizados no quadro 5.8. 


\begin{tabular}{|c|c|}
\hline NÍVEL & INDICADORES HOTELEIROS \\
\hline ESTRATÉGICO & $\begin{array}{l}\text { - Participação no mercado; } \\
\text { - Taxa média de ocupação; } \\
\text { - Evolução do número de clientes; } \\
\text { - Investimento em treinamento; } \\
\text { - Tempo de atendimento ao cliente; } \\
\text { - Rotatividade de empregados; } \\
\text { - Retenção de clientes; } \\
\text { - Número de cancelamento de reservas; } \\
\text { - Retorno sobre o investimento; } \\
\text { - Qualidade do serviço; } \\
\text { - Investimento em móveis, utensílios e } \\
\text { equipamentos; } \\
\text { - Evolução do número de funcionários; } \\
\text { - Satisfação dos clientes; } \\
\text { - Crescimento e mix de receitas; } \\
\text { - Capacidade dos funcionários; } \\
\text { - Sistemas de informação; } \\
\text { - Motivação; } \\
\text { - Número de empregados; } \\
\text { - Taxa de ocupação; } \\
\text { - Expansões e melhoria; } \\
\text { - Qualificação dos funcionários; } \\
\text { - Imagem e reputação do hotel; } \\
\text { - Instalações físicas e equipamentos; } \\
\text { - Opinião de empregados. }\end{array}$ \\
\hline OPERACIONAL & $\begin{array}{l}\text { - Número de reclamações; } \\
\text { - Redução de falhas; } \\
\text { - Receita total; } \\
\text { - Valor econômico agregado; } \\
\text { - Fluxo de caixa; } \\
\text { - Lucro contábil; } \\
\text { - Gestão da qualidade total; } \\
\text { - Redução de custos/melhoria de } \\
\text { produtividade; } \\
\text { - Lucratividade de clientes; } \\
\text { - Medidas de tempo e espera; } \\
\text { - Qualidade do processo; } \\
\text { - Custo dos processos; } \\
\text { - Empowerment e alinhamento; }\end{array}$ \\
\hline
\end{tabular}

Quadro 5.8: Principais Indicadores de Desempenho Utilizados pelos Hotéis Fonte: Harris e Mongiello (2001); Machado, Veras Machado e Holanda (2006); Celestino (2003); Araújo (2001); Leite (2004)

De acordo com Lunkes (2004, p. 225-235), algumas são as características a serem observadas quando se faz a comparação de desempenho e medidas que devem ser aplicadas nos hotéis:

- As melhorias no desempenho estão associadas ao aumento da competência dos colaboradores, sua motivação e pessoal qualificado; 
- A inovação seja tecnológica, de produto ou organizacional, é um dos principais direcionadores de valor para os hotéis;

- O hotel necessita de pessoal qualificado a fim de realizar as mudanças e inovações necessárias a sua sobrevivência;

- Os colaboradores devem ser motivados a fazer sugestões para inovações e melhorias;

- Eficiência no processo pode ser entendida como a capacidade de transformar entradas (inputs) em produtos e serviços (output) ao menor custo;

- O hotel deve ser eficiente entre o início e o término de um processo, podendo corrigir erros a qualquer momento;

- São características intangíveis de produtos e serviços: reputação, gosto, status, estilo e atração, podendo ser tão importantes quanto características tangíveis de alguns hóspedes;

- A percepção em relação ao atendimento durante toda a hospedagem também contribui para atrair e reter os hóspedes.

A importância da recreação e do lazer para Barreto et al. (2004), bem como os preços acessíveis e os bons serviços apontados por Castelli (2000), são importantes para o desempenho da empresa hoteleira. 


\section{TRABALH DE СAMPO}

Este capítulo apresenta os métodos de pesquisa e o levantamento do setor hoteleiro para o trabalho de campo realizado na Região Central do Estado de São Paulo contemplando os Circuitos Paulista da Chapada Guarani e Ecocaipira, abrangendo as cidades de Águas de São Pedro, Analândia, Brotas, Charqueada, Corumbataí, Itirapina, Ipeúna, Piracaia, Rio Claro, Santa Cruz da Conceição, Santa Maria da Serra, São Carlos, São Pedro e Torrinha.

\subsection{MÉTODOS DA PESQUISA - PRIMEIRA E SEGUNDA FASES}

O objetivo desta seção é caracterizar os métodos utilizados no trabalho de campo, além de explicitar a escolha das empresas, as variáveis da pesquisa, as técnicas de coleta e análise de dados.

Visando atingir o objetivo proposto da pesquisa, o trabalho de campo foi realizado em três fases. Para classificação das empresas que fizerem parte da população de estudo, foi considerado o critério do SEBRAE (2008), o qual considera o número de funcionários e o setor.

\begin{tabular}{|c|c|c|}
\hline PORTE & \multicolumn{2}{|c|}{ EMPREGADOS } \\
\hline & Comércio e Serviços & Indústria \\
\hline Microempresa & 1 a 09 & 19 \\
\hline Pequena Empresa & 10 a 49 & 20 a 99 \\
\hline Média Empresa & 50 a 99 & 100 a 499 \\
\hline Grande Empresa & acima de 100 & acima de 500 \\
\hline
\end{tabular}

Quadro 6.1: Classificação das empresas segundo o número de funcionários e o setor Fonte: SEBRAE (2008)

\subsubsection{Primeira Fase}

$\mathrm{Na}$ primeira fase foi realizada uma atualização do mapeamento das empresas hoteleiras da região central do Estado de São Paulo (apêndice D), a partir dos 
mapeamentos realizados pelos trabalhos de Iniciação Científica de Andrade (2004) e dos Mestrados de Brito (2008) e Ribeiro (2008).

O propósito desta primeira fase foi o mapeamento das empresas do setor hoteleiro dos circuitos da Chapada Guarani e Ecocaipira e a caracterização do negócio, do empresário e da gestão. O critério de escolha desses circuitos foi porque são os dois circuitos de turismo oficialmente apoiados pelo governo do Estado de São Paulo. Além disso, são os dois circuitos mais próximos da cidade de São Carlos e da base de atuação do GEOPE/EESC/USP. Nesta fase, foram identificados todos os hotéis, independentemente do porte, mediante telefonemas e outras fontes, a fim de confirmar os contatos, o surgimento de novas empresas hoteleiras na região e algumas informações como o nome da empresa, endereço, endereço eletrônico, nome do(s) proprietário(s), número de UH e número de funcionários. Nessa região, pode-se falar em um cluster hoteleiro, que segundo Andrade (2004) é um agrupamento de empresas da mesma indústria, ou seja, um grande número de empreendimentos hoteleiros importante para o desenvolvimento regional.

Abaixo, são apresentadas no quadro 6.2 as cidades que compõem cada circuito paulista de acordo com cada fonte.

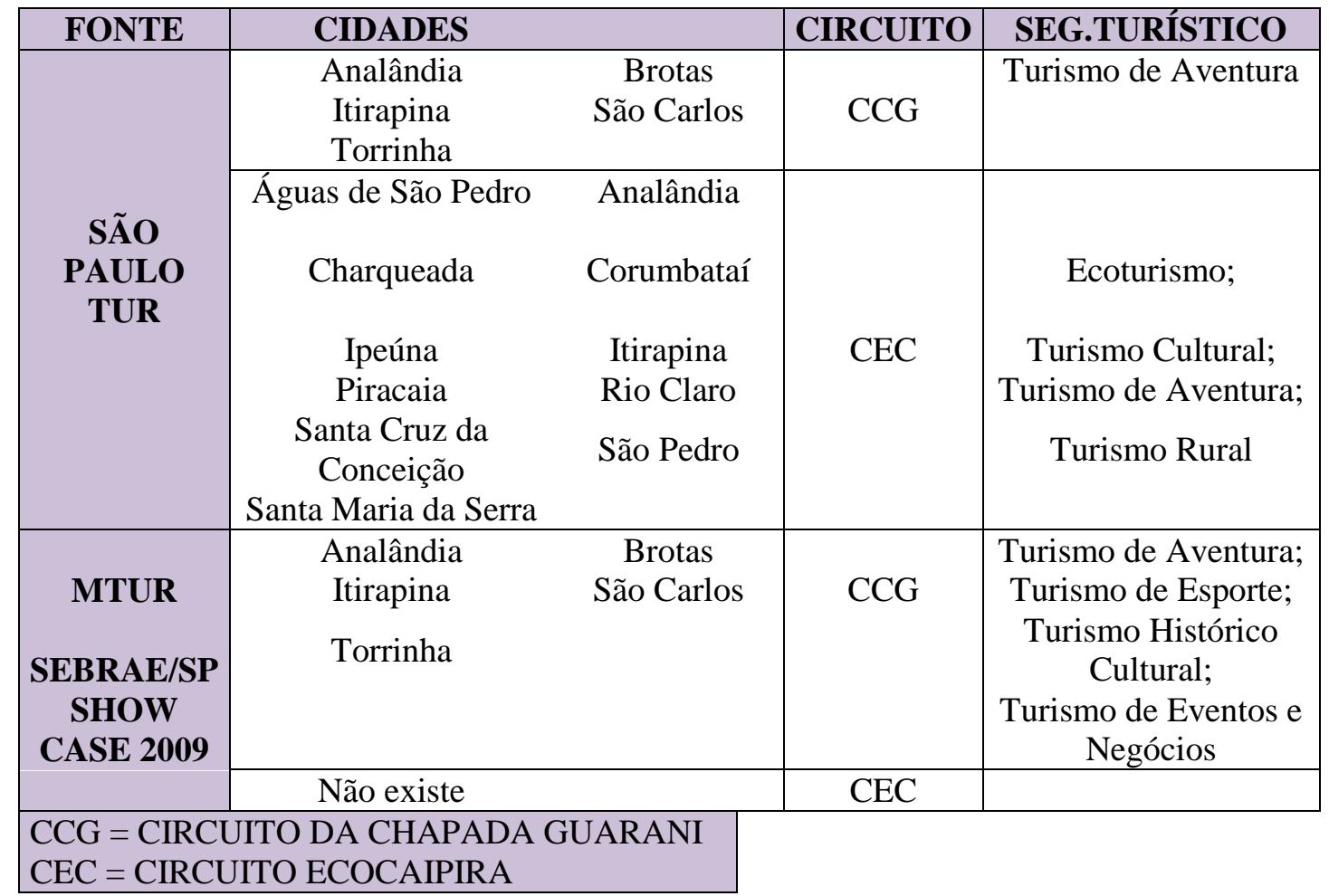

Quadro 6.2: Cidades dos circuitos turísticos 
Para as empresas identificadas foi realizado um contato telefônico para a autorização de uma visita à organização e confirmação de dados já trabalhados por pesquisas anteriores do GEOPE.

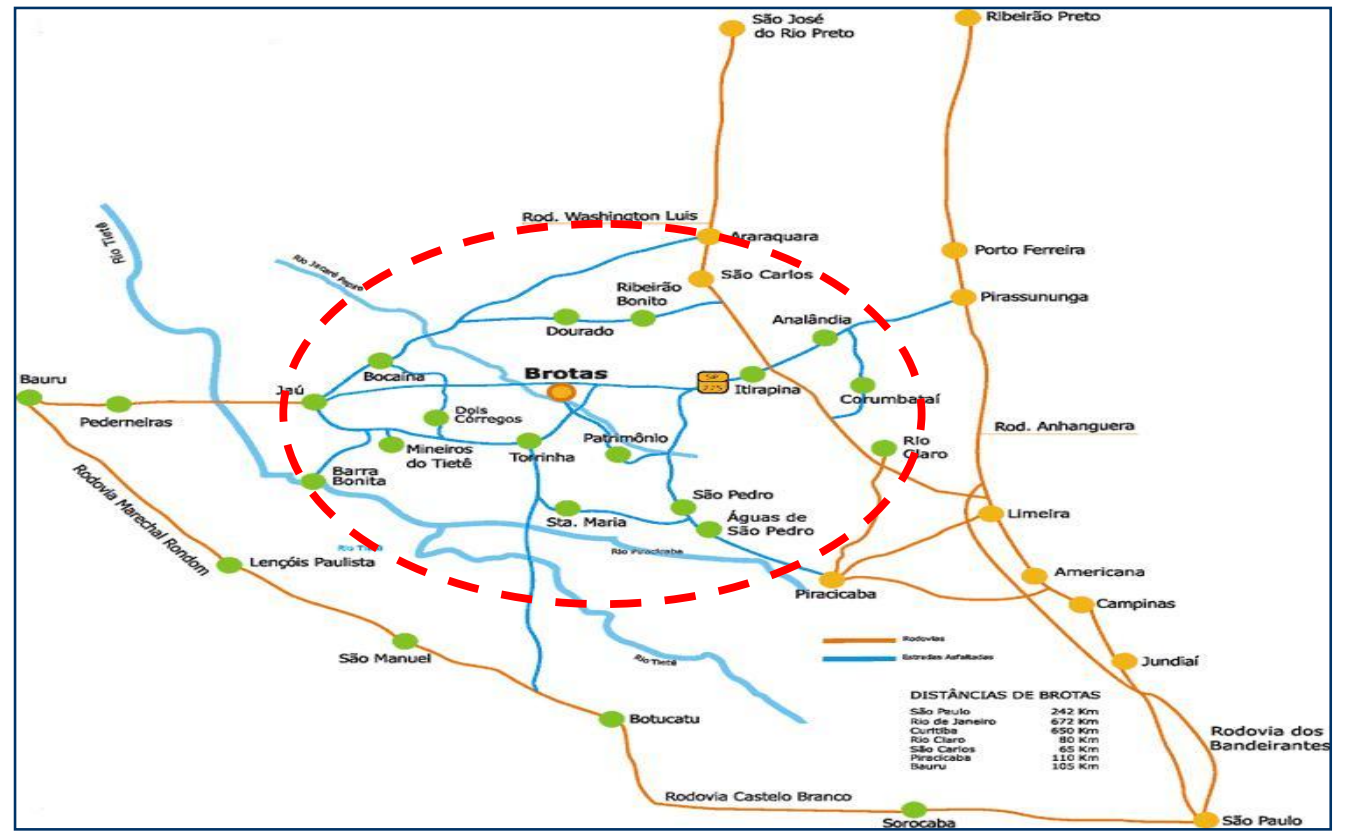

Figura 6.1: Região estudada

Os dados levantados apontaram a existência de 168 empresas hoteleiras em 14 cidades. As atividades das empresas participantes são diversas, conforme apresentado no quadro 6.3, demonstrando a grande heterogeneidade no segmento hoteleiro e seus diferentes enfoques turísticos.

\begin{tabular}{|c|c|}
\hline Cidade & Motivação Turística \\
\hline Águas de São Pedro & lazer e saúde \\
\hline Analândia & lazer e aventura \\
\hline Brotas & lazer e aventura \\
\hline Charqueada & rural \\
\hline Corumbataí & lazer \\
\hline Itirapina & lazer \\
\hline Ipeúna & lazer \\
\hline Piracaia & lazer \\
\hline Rio Claro & negócios \\
\hline Santa Cruz da Conceição & rural \\
\hline Santa Maria da Serra & rural \\
\hline São Carlos & negócios \\
\hline São Pedro & lazer \\
\hline Torrinha & lazer \\
\hline
\end{tabular}

Quadro 6.3: Motivação turística para procura da região 
No gráfico 6.1 é apresentado o número de hotéis em cada cidade.

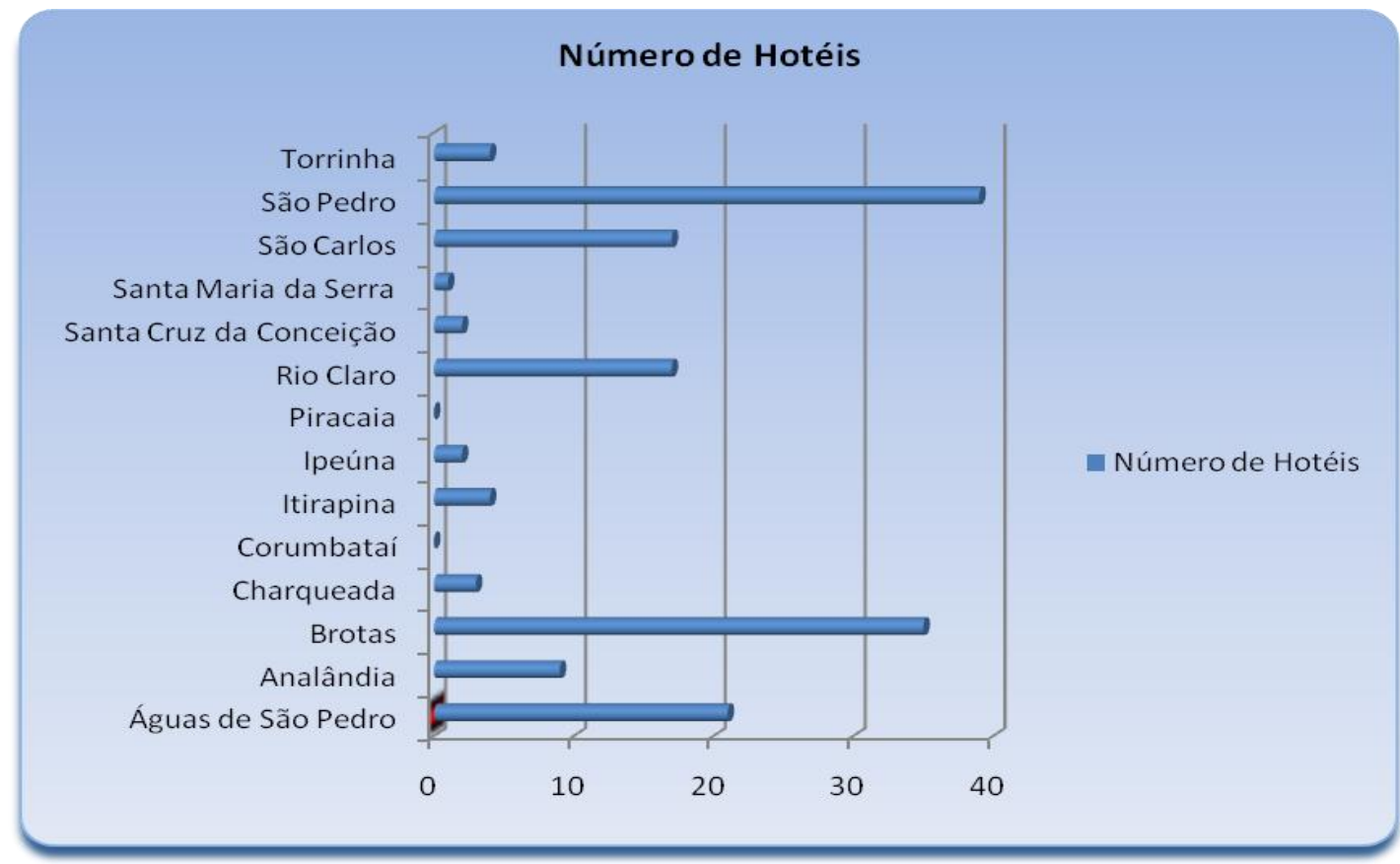

Gráfico 6.1: Distribuição do Número de Hotéis pelas Cidades Estudadas

Exemplos de caracterizações turísticas foram considerados: Brotas conhecida como a "Capital dos Esportes de Aventura"; o turismo de negócios, ligado às universidades e ao potencial aeronáutico de São Carlos e proximidades, à Estância Hidromineral de Águas de São Pedro; e à Estância Climática de Analândia.

As cidades de Analândia, Brotas, Itirapina, São Carlos e Torrinha fazem parte do Circuito Turístico da Chapada Guarani, criado em 2005, conhecidas pelos esportes de aventura, ecoturismo e negócios. A região é caracterizada por relevo forte e pela abundância de águas, como nascentes, rios e cachoeiras que alimentam o Aqüífero Guarani, considerado o $109^{\circ}$ maior reservatório de água subterrânea do mundo. Acontecimentos históricos como a conquista dos bandeirantes e a epopéia do café também marcam a região. A pesquisadora identificou 396 circuitos em todo o país, entre os quais foram selecionados 2 circuitos: Circuito Turístico da Chapada Guarani e Circuito Paulista Ecocaipira.

Já as cidades de Águas de São Pedro, Analândia, Charqueada, Corumbataí, Ipeúna, Itirapina, Piracaia, Rio Claro, Santa Cruz da Conceição, Santa Maria da Serra e São Pedro fazem parte do Circuito Paulista Ecocaipira do Estado de São Paulo. Durante a escolha dos circuitos, houve dificuldade em encontrar fontes seguras e atualizadas em relação às cidades que compõem cada circuito. Foi verificado e conversado com alguns 
responsáveis pelos roteiros que ambos existem oficialmente, mas que por falta de iniciativa de alguns municípios alguns se tornam esquecidos como o Ecocaipira. Confirmou-se durante a pesquisa que o roteiro Ecocaipira está desestruturado, não se regionalizou ainda nos órgãos oficiais, pois não há uma governança local de articulação para desenvolvê-lo e seus atrativos. Deve-se destacar que até em sites governamentais os dados do roteiro Ecocaipira estão inconsistentes. Exemplos dessa desestruturação podem ser vistos no quadro 6.2 que contempla a classificação do Circuito Ecocaipira, que não compõe o roteiro do Estado de São Paulo, conforme apresentado no Salão de Turismo de 2008. Verificou-se que a escolha das cidades e classificação dos circuitos é uma questão política e também uma determinação de cada cidade em fazer parte de algum roteiro na divulgação de seus atrativos; muitas vezes demonstram uma postura passiva.

\subsubsection{Segunda Fase:}

Os resultados do levantamento da Fase 1; geraram as seguintes tabelas:

\begin{tabular}{|c|c|c|c|c|}
\hline CIRCUITO & CIDADES & MICRO/PEQ. & MÉDIA & GRANDE \\
\hline & Analândia & 9 & 0 & 0 \\
\hline & Brotas & 34 & 1 & 0 \\
\hline \multirow[t]{7}{*}{ GUARANI } & Itirapina & 4 & 0 & 0 \\
\hline & São Carlos & 14 & 1 & 2 \\
\hline & Torrinha & 4 & 0 & 0 \\
\hline & Águas de São Pedro & 19 & 1 & 1 \\
\hline & Analândia & 9 & 0 & 0 \\
\hline & Charqueada & 3 & 0 & 0 \\
\hline & Corumbataí & 0 & 0 & 0 \\
\hline \multirow[t]{7}{*}{ ECOCAIPIRA } & Ipeúna & 2 & 0 & 0 \\
\hline & Itirapina & 4 & 0 & 0 \\
\hline & Piracaia & 0 & 0 & 0 \\
\hline & Rio Claro & 17 & 0 & 0 \\
\hline & $\begin{array}{c}\text { Santa Cruz da } \\
\text { Conceição }\end{array}$ & 2 & 0 & 0 \\
\hline & Santa Maria da Serra & 1 & 0 & 0 \\
\hline & São Pedro & 37 & 2 & 0 \\
\hline TOTAL & 14 CIDADES & 159 & 5 & 3 \\
\hline
\end{tabular}

Tabela 6.1: Classificação dos hotéis por porte, segundo o número de unidades habitacionais, e por cidade. 
Ao classificar os hotéis conforme o número de unidades habitacionais como proposto por Duarte (1996) (Quadro 6.4), observa-se que 95\% dos hotéis são considerados como micro/pequenas empresas, $3 \%$ média empresa e $2 \%$ grande empresa. Há um "buraco" existente para a classificação por número de unidades habitacionais, pois não existe uma separação entre micro e pequena empresa.

\begin{tabular}{|c|c|}
\hline PORTE & UNIDADES HABITACIONAIS \\
\hline Microempresa & 01 a 40 \\
\hline Pequena Empresa & 01 a 40 \\
\hline Média Empresa & 41 a 200 \\
\hline Grande Empresa & acima de 201 \\
\hline
\end{tabular}

Quadro 6.4: Classificação das Empresas Segundo o Número de Unidades Habitacionais Fonte: Duarte (1996)

No entanto, verifica-se que o índice de hotéis tende a ser mais distribuído conforme a classificação pelo número de funcionários, como proposto pelo SEBRAE (2008). Os hotéis pertencentes a redes hoteleiras foram classificados como grandes hotéis, independentemente do número de funcionários e unidades habitacionais. Vale ressaltar que a escolha dos hotéis na pesquisa foi pelo número de funcionários e por segmento turístico.

\begin{tabular}{|c|c|c|c|c|c|}
\hline CIRCUITO & CIDADES & MICRO & PEQUENA & MÉDIA & GRANDE \\
\hline & Analândia & 9 & 0 & 0 & 0 \\
\hline & Brotas & 28 & 6 & 1 & 0 \\
\hline & Itirapina & 2 & 2 & 0 & 0 \\
\hline & São Carlos & 5 & 9 & 1 & 2 \\
\hline & Torrinha & 4 & 0 & 0 & 0 \\
\hline & Águas de São Pedro & 17 & 2 & 1 & 1 \\
\hline & Analândia & 9 & 0 & 0 & 0 \\
\hline & Charqueada & 3 & 0 & 0 & 0 \\
\hline & Corumbataí & 0 & 0 & 0 & 0 \\
\hline & Ipeúna & 2 & 0 & 0 & 0 \\
\hline & Itirapina & 2 & 2 & 1 & 0 \\
\hline & Piracaia & 0 & 0 & 0 & 0 \\
\hline & Rio Claro & 12 & 5 & 0 & 0 \\
\hline & Santa Cruz da Conceição & 2 & 0 & 0 & 0 \\
\hline & Santa Maria da Serra & 1 & 0 & 0 & 0 \\
\hline & São Pedro & 32 & 5 & 0 & 2 \\
\hline TOTIRAL & 14 & $\mathbf{1 2 8}$ & $\mathbf{3 1}$ & $\mathbf{4}$ & $\mathbf{5}$ \\
\hline
\end{tabular}

Tabela 6.2: Classificação das cidades dos circuitos paulistas x número funcionários 
O propósito da segunda fase foi caracterizar a preocupação com o controle do desempenho e com as medidas de desempenho da organização. Foi realizada uma escolha de uma amostra da população de hotéis da primeira fase dentro do objetivo proposto (mapeamento das empresas do setor hoteleiro dos circuitos da Chapada Guarani e Ecocaipira e a caracterização do negócio, do empresário e da gestão), conforme a tabela 6.3. Ainda, foram listadas as PMEs e verificado a disponibilidade para a pesquisa. Foi realizado um recorte de 32 hotéis, segundo critérios de intencionalidade porque houve a realização de um estudo comparativo de sete hotéis, escolhidos por conveniência da pesquisa, como mostra a tabela 6.3.

\begin{tabular}{|c|c|c|c|}
\hline SEGMENTO TURÍSTICO & PEQUENA & MÉDIA & GRANDE \\
\hline LAZER & $\begin{array}{c}\text { 2 Itirapina } \\
\text { 4 São Pedro }\end{array}$ & & 1 São Pedro \\
\hline ECOTURISMO & 4 Brotas & 1 Brotas & \\
\hline RURAL & & & 1 São Pedro \\
\hline NEGÓCIOS & 7 São Carlos & 1 São Carlos & 2 São Carlos \\
\cline { 2 - 4 } & 5 Rio Claro & & \\
\hline \multirow{2}{*}{ LAZER E SAÚDE } & $\begin{array}{c}\text { 2 Águas de São } \\
\text { Pedro }\end{array}$ & $\begin{array}{c}\text { 1 Águas de São } \\
\text { Pedro }\end{array}$ & $\begin{array}{c}1 \text { Águas de São } \\
\text { Pedro }\end{array}$ \\
\hline TOTAL & 24 & 3 & 5 \\
\hline
\end{tabular}

Tabela 6.3: Classificação dos hotéis por porte, cidade e segmento turístico, segundo o número de funcionários

A pesquisa, porém, foi feita com uma parte da população, selecionada segundo critérios que garantem sua representatividade (CERVO, 1983): porte, segundo número de funcionários (superior a 20), níveis hierárquicos (nível estratégico ao nível operacional), segmento turístico (lazer, ecoturismo, rural, negócios, lazer e saúde) e circuito turístico. As empresas hoteleiras que fizeram parte do estudo serviram na análise quantitativa de dados. As micro empresas foram excluídas da pesquisa.

A pesquisa quantitativa constituiu uma alternativa apropriada aos estágios iniciais da investigação, buscando explorar o objeto de estudo e delimitar as fronteiras do trabalho.

\subsection{MÉTODOS DE PESQUISA - TERCEIRA FASE}

O objetivo desta fase foi verificar quais os indicadores utilizados na medição de desempenho e verificar se eles estão orientados para a competitividade. Semelhanças 
e diferenças de procedimentos de medição de desempenho entre pequenas e médias empresas de um lado, e de grandes hotéis de outro lado, foram descritas. As razões das diferenças e as formas de superar os obstáculos de adoção de sistemas eficazes de medição foram propostas neste trabalho.

Essa fase pode ser caracterizada como intencional (não-probabilística), pois foram escolhidos por conveniência da pesquisa cinco hotéis (PME) para se obter dados mais construtivos do relacionamento com os dois grandes hotéis. Tomado o referencial dos dois grandes hotéis como definidor dos fatores críticos de competitividade, foi realizada uma investigação empírica entre os pequenos, médios hotéis e grandes hotéis com o propósito comparativo. Também foi discutida a conveniência, ou não, de tomar as práticas dos grandes hotéis como representativo dos fatores críticos de sucesso e, conseqüentemente, orientações para o desempenho dos pequenos e médios hotéis.

\subsubsection{Caracterização da Pesquisa}

\section{a) Quanto à ênfase, é aplicada.}

É aplicada porque gera conhecimentos que podem ser postos em prática, ou seja, utilizados na solução de problemas específicos.

\section{b) Quanto aos propósitos, é descritiva.}

É descritiva, pois observa, registra, analisa e correlaciona fatos ou fenômenos (variáveis) sem manipulá-los. Estuda fatos e fenômenos do mundo físico e do mundo humano. Procura descobrir, com a precisão possível a frequiência com que um fenômeno ocorre, sua relação e conexão com outros, sua natureza e características. Trata-se do estudo e descrição das características, propriedades ou relações existentes nas comunidades, grupo ou realidade pesquisada (CERVO, 1983). Tem como questões básicas de uma pesquisa descritiva as seguintes: Que é? Como ocorre? Por quê?

\section{c) Quanto à abordagem do problema, é qualitativa.}

É qualitativa, pois o ambiente natural é a fonte direta para coleta de dados e o pesquisador é o instrumento-chave, não requerendo o uso de métodos e técnicas estatísticas (SILVA; MENEZES, 2001). 
A metodologia nesta terceira fase da pesquisa se concentrou na abordagem qualitativa, utilizada para interpretar fenômenos, na qual a pesquisadora participou do processo para obter uma formulação conceitual. Utilizou a observação e a comunicação, interpretando os fatos e seu raciocínio foi indutivo, assim como aponta o Instituto Ethos (2008). Diferentemente de uma pesquisa quantitativa na qual o pesquisador conduz seu trabalho a partir de um plano estabelecido a priori, com hipóteses específicas e variáveis definidas, na pesquisa qualitativa a pesquisadora não mediu e nem enumerou eventos estudados (GODOY, 1995a). Neste tipo de pesquisa, um fenômeno pode ser melhor compreendido no contexto em que ocorre e do que faz parte, devendo ser analisado numa perspectiva integrada. Desta forma, a pesquisadora foi a campo para captar o fenômeno em estudo a partir das perspectivas das pessoas envolvidas e de seus pontos de vista relevantes (GODOY, 1995b).

De acordo com Ethos (2008), a pesquisa qualitativa é uma ferramenta que determina o que é importante e porque é importante. A pesquisa qualitativa proporcionou a pesquisadora um processo na qual as questões-chave foram identificadas e perguntas foram formuladas, descobrindo, dessa maneira, o que importa para os clientes e por que. Um ponto importante a ser considerado na pesquisa qualitativa é possibilidade de usar diversas técnicas de coleta de dados, o que traz uma possibilidade e amplitude à pesquisa, na qual se aplica no estudo de casos que se baseia em várias fontes de evidências (YIN, 2005). Também deve considerar que a pesquisa qualitativa foi usada para identificar a quantidade total de respostas ou opiniões que existem nas empresas hoteleiras da região central do Estado de São Paulo.

De acordo com Godoy (1995a), a pesquisa qualitativa tem como características e foram utilizadas nesta pesquisa:

o ambiente natural como fonte direta de dados e o pesquisador como instrumento fundamental;

$>$ tem papel fundamental de descrever os dados;

$>$ compreende os fenômenos que estão sendo estudados a partir da perspectiva dos participantes;

\section{d) Quanto aos procedimentos técnicos, é um estudo de casos.}

É um estudo de casos, pois consiste em investigar coisas ou fatos e explicá-los a partir de suas semelhanças e suas diferenças (FACHIN, 2002); é uma unidade de 
análise mais precisa que visa o exame detalhado de um ambiente, de um sujeito ou uma situação em particular (GODOY, 1995b). Seu propósito é analisar uma dada unidade social, aprofundar a descrição de determinado fenômeno e procurar responder às questões "como" e "por que" certos acontecimentos ocorrem (GODOY, 1995b). Pode ser considerado como uma estratégia apropriada para a análise de acontecimentos contemporâneos, quando não se podem manipular comportamentos relevantes, ou seja, quando os limites entre o fenômeno e o contexto não estão claramente definidos (YIN, 2005). De acordo com os procedimentos técnicos, o estudo de comparativo de casos é caracterizado como:

\footnotetext{
"uma investigação empírica de um fenômeno contemporâneo dentro de seu contexto da vida real, especialmente quando os limites entre o fenômeno e o contexto não estão claramente definidos" (YIN, 2005, p.32).
}

A seleção dos métodos de pesquisa foi a realização de estudo de casos em empresas de diferentes portes do setor hoteleiro da região central do estado de São Paulo. Esse setor já vem sendo estudado pelo Grupo de Estudos Organizacionais na Pequena Empresa (GEOPE) em pesquisas anteriores, há pelo menos doze anos.

Yin (2005) e Godoy (1995b) ainda explicam que a investigação de estudo de casos enfrenta uma situação única em que haverá muito mais variáveis de interesse do que pontos de dados. Como resultado, a pesquisadora se baseou em várias fontes de evidências e se beneficiou do desenvolvimento prévio de proposições teóricas para conduzir a coleta e a análise de dados. A pesquisadora produziu relatórios informais, narrativos, ilustrado com citações, exemplos e descrições fornecidos pelo respondente, podendo também utilizar fotos, desenhos, colagens, ou qualquer outro tipo de material que a auxiliou na transcrição do caso.

Considerando as definições de Mendes (2002), o estudo de casos tem as seguintes características:

- Está ligado ao contexto ou processo estudado;

- Essa abordagem não representa um método único, mas uma estratégia de pesquisa que permite o uso de métodos qualitativos e quantitativos.

Yin (2005) também apresenta uma série de habilidades necessárias que um pesquisador deve ter para a realização de um estudo de caso:

- deve ser capaz de fazer boas perguntas e interpretar as respostas;

- deve ser um bom ouvinte e não ser enganado por suas ideologias; 
- deve ser adaptável e flexível; as situações devem ser vistas como oportunidades e não ameaças;

- deve ter uma noção clara das questões abordadas;

- deve ser imparcial em relação a noções, ser sensível e estar atenta a provas contraditórias.

O estudo de caso foi adequado a este trabalho, pois nesta fase interativa envolvendo pesquisadora e sujeitos investigados - utilizaram-se como instrumentos para coleta de dados, a entrevista e a observação. A coleta de dados, que envolve a pesquisadora e os sujeitos investigados, foi realizada mediante a observação livre e entrevistas com os proprietários-gerentes e gerentes das empresas selecionadas, como forma de interação entre o pesquisador e o objeto de pesquisa.

\section{e) Quanto a Escolha das Empresas}

Para construir os fatores críticos de competitividade do setor foi tomado como referência dois grandes hotéis da região. A amostra foi classificada como intencional porque houve a realização de um estudo comparativo de sete hotéis, escolhidos por conveniência da pesquisa, com a observação de "práticas gerenciais formais" em grandes empresas, e a concordância dos proprietários/dirigentes e dirigentes das pequenas e médias empresas para um trabalho mais detalhado e sistematizado em seus estabelecimentos. Para Marconi e Lakatos (1999), a amostra intencional ou por julgamento pode não ser feita com base na representatividade da amostra, mas a escolha pode ser feita com base nas contribuições que ela possa oferecer. Dessa maneira, a escolha intencional garantiu que as empresas hoteleiras selecionadas fossem relevantes ao tema e às questões de análise, visto que a pesquisadora buscou observar as práticas gerenciais das empresas.

Após selecionar as empresas, foi enviado um ofício de pesquisa com os principais objetivos e, simultaneamente, um convite para participação do estudo de casos (ver apêndice B). Segundo o objetivo, foi escolhido dois grandes hotéis que fazem uso de "indicadores de medição de desempenho", e mais cinco empresas, sendo quatro pequenas e uma média do setor de serviços hoteleiro da região central do Estado de São Paulo. Cabe salientar que não foi aplicada a pesquisa em três grandes hotéis como proposto. A escolha dessa amostra teve a intenção de realizar um estudo comparativo entre os três diferentes portes de empresas desse setor. Trabalhar com um 
número maior de empresas não foi possível nesse momento devido ao propósito de aprofundar e fazer análises qualitativas sobre a amostra escolhida.

Teve-se a consciência que esse procedimento de tomar dois grandes hotéis como referência foi limitado. No entanto, o próprio governo adota tal metodologia para definir índices dos setores econômicos no Brasil (Banco Central do Brasil, 2009). Justifica-se tal medida pela dificuldade de acesso a um maior número de fontes de dados.

\subsubsection{Questões da Pesquisa}

Em face da revisão bibliográfica desenvolvida, as questões de pesquisa foram:

- Como os pequenos e médios empreendimentos hoteleiros medem o seu desempenho?

- Há relação entre o tamanho da empresa, a formalização da organização e a prática de medição de desempenho organizacional?

- Há relação entre o grau de concorrência e a prática de medição de desempenho?

- Como as características das empresas hoteleiras influenciam os indicadores de medição de desempenho?

\subsubsection{Variáveis da Pesquisa}

De acordo com o objetivo proposto, as variáveis da pesquisa são:

○ Especificidades de Gestão das Pequenas e Médias Empresas: refere-se à características peculiares da pequena empresa como dirigente, ambiente e organização, que afetam a forma e prática de sua gestão.

○ Empresa Hoteleira: pode ser considerada como uma organização que, mediante o pagamento de diárias, oferece alojamento a clientela indiscriminada;

- Medição de Desempenho Organizacional: retrata a eficácia de elementos no âmbito interno (empregados, clientes, fornecedores, produtos, serviços, etc.) quanto externo (produto em campo, clientes, fornecedores, marca, etc.) da empresa. 


\subsubsection{Técnica de Coleta de Dados}

\section{a) Entrevista}

Durante o estudo de caso, as entrevistas funcionaram como o encontro entre a pesquisadora e o entrevistado. A entrevista é considerada como a técnica mais utilizada em projetos científicos (BONI; QUARESMA, 2005). Haguette (2001, p.86) define a como:

"um processo de interação social entre duas pessoas na qual uma delas, o entrevistador, tem por objetivo a obtenção de informações por parte do outro, o entrevistado".

De acordo com o propósito da pesquisa, as entrevistas foram estruturadas pois a entrevistadora seguiu um roteiro definido. A entrevista também foi caracterizada como aberta, pois a pesquisadora tentou obter o maior número possível de informações sobre determinado tema; a pesquisadora introduziu o tema e o entrevistado teve a liberdade para discorrer sobre o tema sugerido.

São vantagens da entrevista, segundo Marconi e Lakatos (1990) e Gressler (2003) e, foram explorados nesta pesquisa:

1) oferecer maior análise de atitudes, condutas, etc., podendo observar o entrevistado naquilo que diz e como diz;

2) dar a oportunidade de obtenção de dados que não são encontradas na literatura;

3) permitir que o entrevistador consiga informações mais precisas e relevantes;

4) dispensar o participante da leitura de questões e permite maior interação entre o pesquisador e o informante.

A preparação da entrevista é uma das etapas mais importantes da pesquisa que requer tempo e exige alguns cuidados (MARCONI; LAKATOS, 1990), e foram tomados os seguintes nesta pesquisa:

1) o planejamento da entrevista, na qual o entrevistador deve ter em vista o objetivo a ser alcançado;

2) a escolha do entrevistado, que deve ser alguém com familiaridade com o tema pesquisado;

3) a disponibilidade do entrevistado em fornecer a entrevista;

4) as condições favoráveis que possam garantir ao entrevistado o sigilo, a ética, de suas confidências e de sua identidade;

5) a preparação em organizar um roteiro ou formulário com as questões importantes. 
A pesquisadora realizou entrevistas individualmente com os proprietáriosgerentes e gerentes das empresas selecionadas. Foram realizadas quinze entrevistas e apenas uma grande organização foi realizada uma única entrevista devido à falta de tempo do dirigente. As mesmas foram realizadas individualmente e se basearam em um roteiro pré-definido, originado da revisão bibliográfica. As entrevistas foram gravadas e transcritas e posteriormente enviadas aos respondentes e assinadas (consentimento dos entrevistados).

\section{b) Roteiro de Entrevistas}

A pesquisadora seguiu um método ou um roteiro de entrevista que identificou as etapas básicas na construção de um instrumento eficaz. O roteiro de entrevista serviu como uma intenção de trajetória, além de ajudar a pesquisadora a se organizar antes da entrevista (APÊNDICE C). Além disso, o roteiro de entrevista apresentou outras funções, como aponta Duarte (2002):

- auxiliou a pesquisadora a se organizar antes e no momento da entrevista;

- auxiliou o entrevistado a fornecer a informação de forma mais precisa e com maior facilidade;

- auxiliou parcialmente na organização da interação social no momento da entrevista;

- garantiu a organização dos conceitos previamente estabelecidos no roteiro e o não esquecimento de algum item ou pergunta no decorrer da entrevista.

Para Duarte (2002) e Gressler (2003), o roteiro de entrevista é um instrumento flexível que precisa ser periodicamente revisto para que se possa avaliar se ainda atende os objetivos definidos da investigação. Num roteiro de entrevista, o pesquisador deve observar questões que envolvem a linguagem; atentar que a intimidade com o entrevistado é um diferencial para adequar a linguagem, estar presente nas perguntas exibidas no roteiro, além de auxiliar na compreensão das palavras faladas.

Alguns problemas são freqüentemente constatados nos roteiros de entrevista, como o uso de palavras próprias do pesquisador (jargão técnico); utilização de uma pergunta única para investigar um conceito complexo; a dificuldade de se obter respostas condizentes com os objetivos para uma pergunta específica (DUARTE, 2002).

A elaboração do roteiro de entrevistas foi essencial para esta pesquisa, visto que funcionou como um mapa para a pesquisadora se organizar antes das mesmas. Auxiliou a pesquisadora obter informações mais precisas e com maior facilidade dos 
entrevistados, auxiliou na interação social no momento da entrevista e garantiu a organização dos conceitos previamente estabelecidos no roteiro e o não esquecimento de algum item. Conclui-se que uma entrevista bem sucedida depende muito do domínio do pesquisador sobre as questões previstas no roteiro de pesquisa. $\mathrm{O}$ conhecimento do tema evitou confusões e ajudou a pesquisadora fazer perguntas claras e obter respostas também claras que responderam aos objetivos da investigação. Vale considerar que neste trabalho foi planejado o protocolo de pesquisa que se encontra no apêndice $\mathrm{C}$.

\subsubsection{Técnica de Análise dos Dados}

A análise dos dados obtidos junto às organizações seguiu as orientações de Bardin (1979) com relação à análise de conteúdo categorial, constituindo na prática:

a) Prée-análise: organização do material (padronização do diário de campo, na qual não se encontra anexo nesta pesquisa devido à ética da pesquisadora com o sigilo dos dados);

Escolheu-se alguns elementos a serem analisados, que foram: as visitas iniciais, os sites, as entrevistas, e a observação livre; formulou-se o roteiro de entrevista e, elaborou os indicadores que fundamentaram a interpretação final.

b) Exploração do material: momento de escolha:

As categorias: foram os grandes temas ou as variáveis da pesquisa, sendo:

a) Estratégia, Planejamento e Aprendizado;

b) Organização e Desempenho;

c) Especificidades das Pequenas e Médias Empresas;

d) Setor de Serviços: Turismo e Hotelaria.

As unidades de registro: foram os subtemas, sendo:

a) Estratégia - Objetivos e Metas - Planejamento - Planejamento Estratégico - Emersão;

b) Controle do Desempenho- Desempenho e Medição de Desempenho - Indicadores de Medição de Desempenho;

c) Dirigente - Organização - Contexto;

d) Serviços - Turismo - Empresa Hoteleira - Meios de Hospedagem - Medição de Desempenho na Hotelaria.

$\mathrm{E}$ as regras de contagem foram estabelecidas pela presença de elementos significativos. 


\section{c) Tratamento dos resultados:}

A inferência utilizou-se das entrevistas realizadas e dos registros feitos no Diário de Campo. Na interpretação houve a exposição de conceitos teóricos e reflexões mais abrangentes para o setor estudado.

\subsubsection{Protocolo de Estudo de Caso}

O foco na qualidade da pesquisa de estudo de caso sugere a necessidade de uma análise ou de uma estrutura de validação de consistência da configuração metodológica como referencial de avaliação da qualidade da intervenção realizada ou a ser desenvolvida. Com o objetivo de avaliar a coerência das relações estabelecidas entre as dimensões e decisões de encaminhamento de uma pesquisa, Mazzon ${ }^{11}$ (1981 apud Telles, 2001) propôs um instrumento denominado matriz de amarração, que analisa a questão da aderência e da compatibilidade entre modelo de pesquisa, objetivos da pesquisa, hipóteses de pesquisa e técnicas de análise planejadas para tratamento dos dados em termos qualitativos de um ponto de vista sistêmico.

Telles (2001) aponta a matriz de amarração como uma etapa necessária para a identificação de sua configuração, transparência de suas limitações e avaliação de suas efetividade e eficácia, na qual facilita uma visão sintética da intervenção planejada (ou realizada), sua revisão e/ou modificação, em virtude da análise integrada do estudo que propicia para o pesquisador.

Um exemplo de matriz de amarração é o roteiro de entrevista proposto nesta dissertação, no Apêndice C, uma maneira eficaz de lidar com o problema de aumentar a confiabilidade dos estudos de caso. Para Yin (2005), a melhor maneira de preparar os dados para pesquisa qualitativa é definir o problema de pesquisa, deixando claro que o estudo de caso é o melhor método, a melhor estratégia a ser realizado na pesquisa, como para estruturar a coleta de dados e apresentar as perguntas principais; e por fim, preparar o protocolo relacionado as atividades a serem realizadas e os procedimentos a serem seguidos.

Salienta-se que o Protocolo de Estudo de Caso foi útil na readequação teórica desta pesquisa. Durante o trabalho de campo foi identificado que ao construir o

\footnotetext{
${ }^{11}$ MAZZON, J. A. Análise do programa de alimentação do trabalhador sob o conceito de marketing social. 1981. Tese (Doutorado). Faculdade de Economia, Administração e Contabilidade da Universidade de São Paulo, São Paulo, 1981.
} 
protocolo de estudo de caso, algumas mudanças eram necessárias em relação aos conceitos e variáveis da pesquisa. Durante a terceira entrevista, na qual a pesquisadora estava em contato com organizações de pequeno porte, verificou-se a necessidade de incluir uma pergunta referente às razões do proprietário-dirigente iniciar o negócio, vista como uma maneira de identificar a dimensão dirigente (características pessoais), dimensão organização (aspectos internos) e dimensão contexto (aspectos externos).

\subsubsection{Aspectos Éticos na Pesquisa Científica}

A reflexão sobre ética na pesquisa é uma trata da coleta e análise dos dados, o alvo é apenas orientar o leitor a ser bem-sucedido em sua pesquisa (YIN, 2005; CHAGAS, 2000). Se a pesquisa envolve pesquisadores preocupação recente nos manuais de divulgação da investigação científica. A maioria dos livros de metodologia científica ensina a elaborar projetos de pesquisa, mas, quando se e pesquisados, é importante que a ética conduza as ações de pesquisa, de modo que a investigação não traga prejuízo para nenhuma das partes envolvidas.

Mas falar em ética em pesquisa diz respeito a quê?

- ao comportamento entre pesquisadores;

- ao comportamento do pesquisador frente ao leigo;

- aos efeitos da pesquisa sobre terceiros, sobre o meio ambiente;

- a fraudes cometidas na ciência;

Segundo Boerngertz (1999), a ética na pesquisa científica indica que o estudo em questão deve ser feito de modo a procurar o conhecimento, seja por observação, identificação, descrição, investigação experimental, na qual produz resultados reprodutíveis, realizado de forma moralmente correta.

A ética do pesquisador é fundamental em qualquer produção do conhecimento. A ética não pode ser tratada "a posterior" dos processos de investigação. Ela deve entremear todo o processo, uma vez que o sujeito que elabora o conhecimento, e ao mesmo tempo desempenha o papel de investigador, cientista, cidadão, pertence a um grupo social com interesses e valores específicos. O aspecto científico deve ressaltar as qualidades morais como a busca da verdade, a honestidade intelectual e a crítica (MELLO, 2005; LEEDY; ORMROD, 2004). 
Os procedimentos adotados nesta pesquisa para garantir a ética foram:

- Formulação de um ofício de pesquisa, com os principais objetivos da pesquisa, comprometimento da pesquisadora do sigilo com os dados coletados e do entrevistado, além de abordar o envio da transcrição da entrevista para aprovação e consentimento do entrevistado (APÊNDICE B);

- Nas primeiras visitas as organizações pertencentes à pesquisa, a pesquisadora teve o consentimento do entrevistado para gravar as entrevistas;

- As entrevistas foram transcritas pela pesquisadora;

- As entrevistas transcritas foram enviadas ao entrevistado para o consentimento. As transcrições geraram um volume de 60 páginas, mas que por motivos éticos não fazem parte desse trabalho;

- Teve-se o sigilo com os nomes das empresas e dos entrevistados;

- A pesquisadora elaborou um diário de campo contendo informações relevantes tanto de observação como interpretação de dados, totalizando um volume de 20 páginas, mas que por motivos também éticos não consta neste trabalho.

\subsection{DESCRIÇÃO DAS EMPRESAS ESTUDADAS}

Optou-se por trabalhar com diferentes tipos de meios de hospedagem e segmentos turísticos: um SPA e um hotel fazenda com características de ecoturismo; dois hotéis voltados para o setor de negócios; três hotéis com características voltadas ao lazer, sendo um com foco também em saúde. Foram estudados, portanto, quatro tipos de meios de hospedagem. Os respectivos estabelecimentos hoteleiros estavam constituídos em: dois de grande porte, um de médio porte e quatro de pequeno porte (quadro 6.5). Apesar de as empresas estudadas serem caracterizadas com diferentes tipos de meios de hospedagem para efeito de padronização e facilitação na apresentação dos dados da pesquisa, elas serão chamadas de hotel e classificadas de A a G. Os dados coletados junto a tais empresas foram sistematizados em um diário de campo para então serem organizados e apresentados. Cabe ressaltar que o foco da pesquisa foram as pequenas e médias empresas, embora foram utilizadas duas grandes empresas para identificar os fatores fatores-chave de competitividade do setor hoteleiro, já que o próprio governo 
baseia-se nos indicadores das grandes organizações (BANCO CENTRAL DO BRASIL, 2009).

\begin{tabular}{|c|c|c|c|c|}
\hline Empresa & Porte & $\begin{array}{c}\text { Tipo Meio de } \\
\text { Hospedagem }\end{array}$ & $\begin{array}{c}\mathbf{N}^{\mathbf{0}} \\
\text { Funcionários }\end{array}$ & $\begin{array}{c}\mathbf{N}^{\mathbf{0}} \text { Unidades } \\
\text { Habitacionais }\end{array}$ \\
\hline Hotel A & Grande & $\begin{array}{c}\text { Hogóc } \\
\text { Negócios }\end{array}$ & 22 & 112 \\
\hline Hotel B & Grande & Hotel Lazer & 215 & 112 \\
\hline Hotel C & Média & $\begin{array}{c}\text { Hotel } \\
\text { Lazer/Saúde }\end{array}$ & 80 & 126 \\
\hline Hotel D & Pequena & $\begin{array}{c}\text { Hotel } \\
\text { Negócios }\end{array}$ & 20 & 51 \\
\hline Hotel E & Pequena & Hotel Lazer & 46 & 81 \\
\hline Hotel F & Pequena & Fazenda Hotel & 32 & 50 \\
\hline Hotel G & Pequena & SPA & 24 & 50 \\
\hline
\end{tabular}

Quadro 6.5: Principais características das empresas estudadas Fonte: elaboração própria

\subsubsection{HOTEL A}

A unidade estudada faz parte de uma grande rede hoteleira de forma que foi considerada como uma empresa de grande porte; a organização pesquisada é um típico hotel urbano. Pertencente a uma rede internacional, é um dos maiores grupos mundiais de hotelaria, turismo e serviços há 30 anos no Brasil e presente em 140 países. A organização possui aproximadamente 4 mil hotéis em quase todo o mundo. Fundado em 2001, o hotel possui 112 unidades habitacionais e 22 funcionários. O gerente-geral e entrevistado, formado em Educação Física e com especialização em Hotelaria, têm experiência na área há 16 anos. Cabe ressaltar que a diretoria não está presente no HOTEL A, apenas delega as metas e objetivos à unidade; localizada em São Paulo. O organograma do HOTEL A está representado na figura 6.2. 


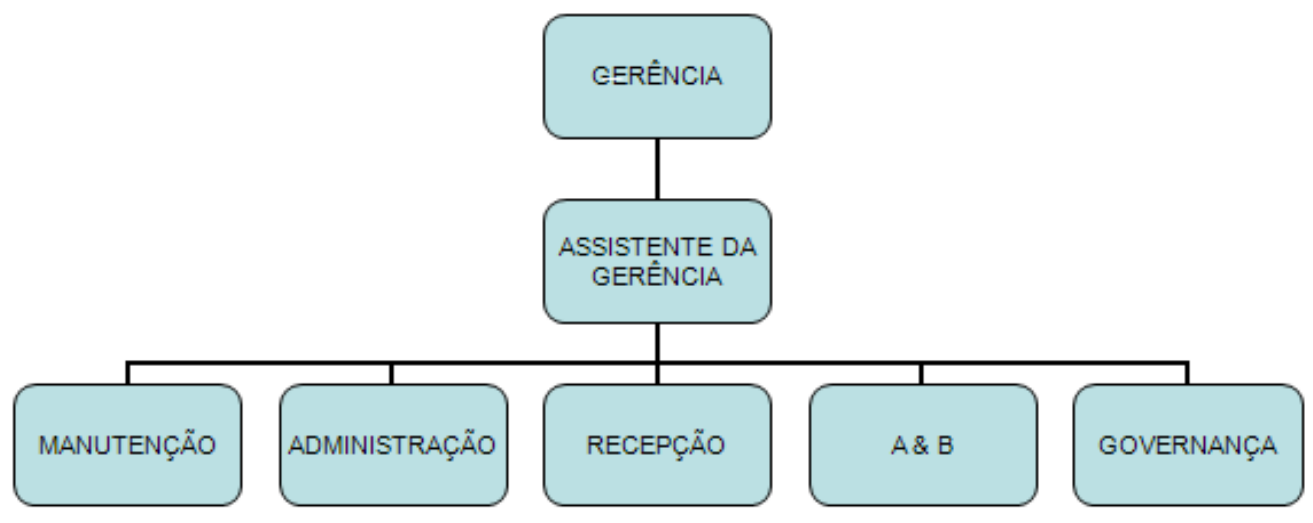

Figura 6.2: Organograma do HOTEL A

Como diferenciais a empresa oferece café da manhã (não incluso na diária), tarifa econômica com custo baixo, infra-estrutura moderna, wireless nos apartamentos e salas para eventos. Os principais clientes são aqueles que vêm à cidade por motivos acadêmicos e de negócios, na grande maioria pessoas físicas.

\subsubsection{HOTEL B}

Considerado como um grande hotel de luxo de cinco estrelas, a organização estudada é um tipo hotel de lazer e saúde. O hotel está ligado a uma instituição de ensino, no qual o diferencia dos demais. Fundado em 1940, o hotel possui 112 unidades habitacionais e aproximadamente 215 funcionários. O grande número de funcionários do HOTEL B deve-se por ser um hotel-escola, com muita mão-de-obra, pois o aluno vivencia uma operação de hotel. O entrevistado foi o subgerente, formado em Gastronomia, Hotelaria e com especialização em Administração, tem experiência na área há 9 anos. A estrutura hierárquica do HOTEL B é composta pela instituição mantenedora (diretor), que não está presente na unidade, um gerente-geral, um subgerente, gerentes de departamentos, chefes de departamentos, recepcionistas, cozinheiros, manobristas, etc. O organograma é formalizado e as funções são bem definidas. O organograma do HOTEL B está representado na figura 6.3. 


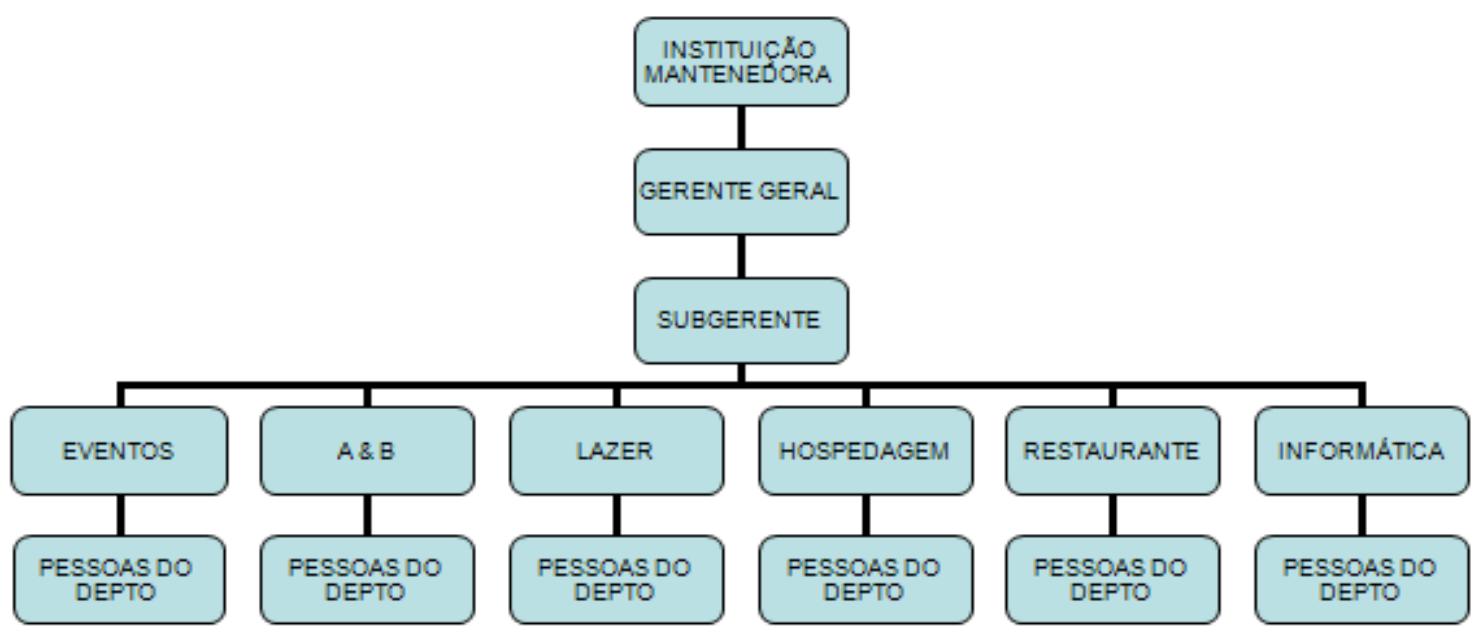

Figura 6.3: Organograma do HOTEL B

O hotel possui diversos atrativos, tais como: quadras poliesportivas; quadra de tênis; piscinas frias e aquecidas; bosque; restaurante internacional; banhos medicinais; salão de jogos; salão de festas; espaço para reuniões e conferências, campo de golf, dentre outros. O destino é motivado por lazer e saúde, que coincidem com o destino da cidade.

\subsubsection{HOTEL C}

Considerado como uma empresa de médio porte, a organização pesquisada é um típico hotel de lazer e saúde de gestão familiar. Fundado em 1967, o hotel possui 120 unidades habitacionais e conta com 70 funcionários. O gerente geral, formado em Administração Hoteleira com especialização em Administração Financeira, tem 35 anos de experiência na área hoteleira. É uma das empresas hoteleiras mais tradicionais da cidade. O organograma do HOTEL C está representado na figura 6.6. 


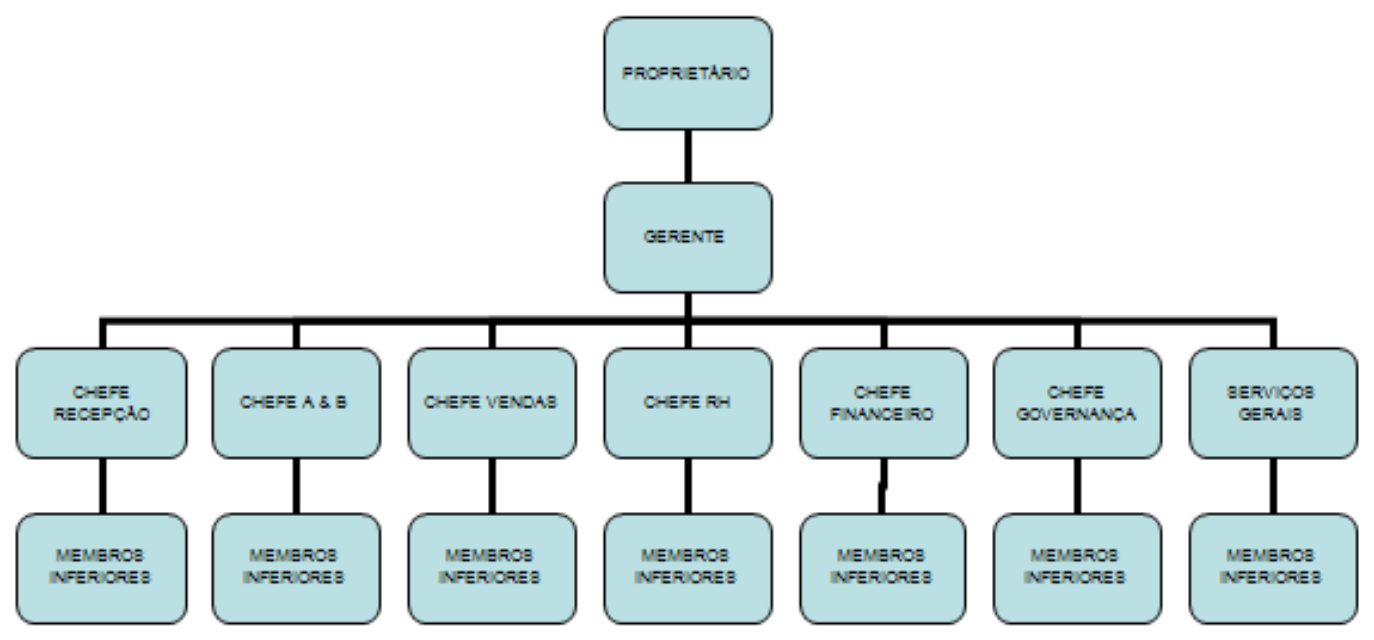

Figura 6.4: Organograma do HOTEL C

O hotel possui como atrativos: piscinas, quadra de tênis, quadras poliesportivas, restaurante, seresta, banhos medicinais, sala para convenções, dentre outros. A procura dos clientes ao hotel é motivada pelos quesitos de saúde e lazer. Atualmente os clientes são pessoas físicas, principalmente da terceira idade, e têm se mostrado uma boa oportunidade para aumentar as vendas. O hotel também oferece pensão completa aos hóspedes.

\subsubsection{HOTEL D}

Considerado um típico hotel urbano voltado para a área de negócios e eventos realizados nas universidades, o proprietário possui 2 unidades. Fundado em 1966, a organização possui 51 unidades habitacionais e conta com 20 funcionários, sendo 32 UH e 19 UH em cada um dos hotéis. O diretor/proprietário está presente na organização, mas o entrevistado foi seu filho gerente/proprietário, formado em Administração e com especialização em hotelaria, com 19 anos de experiência. A organização conta com dois hotéis, sendo eles na região central do Estado de São Paulo. O organograma característico da empresa é o seguinte: 


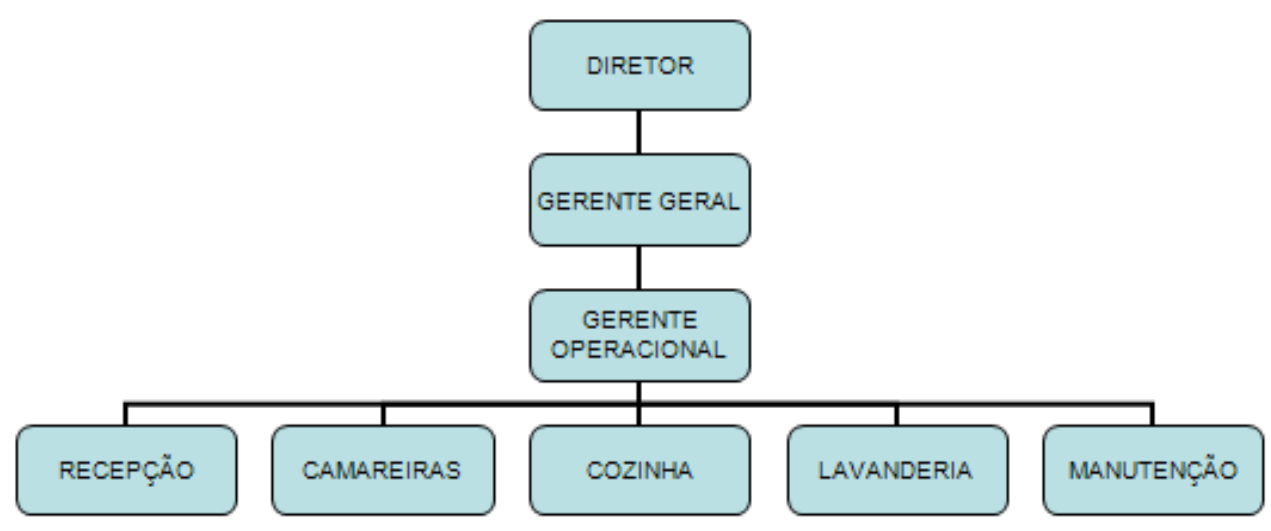

Figura 6.5: Organograma do HOTEL D

Nas duas unidades são oferecidos serviços de café-da-manhã e internet. É uma empresa familiar dirigida pelo proprietário e seu filho. O diferencial é estar próximo à rodoviária e a uma das universidades da cidade.

\subsubsection{HOTEL E}

Considerado um hotel urbano voltado para a área de lazer e eventos, a organização possui 2 unidades. Fundado em 1999, a organização tem 81 unidades habitacionais, sendo 39 na região central do Estado de São Paulo e 42 na unidade localizada no litoral de São Paulo e conta com 46 funcionários nas duas unidades. A organização pesquisada é um típico hotel de lazer e saúde de gestão familiar, mas a família não está em contato direto com as duas unidades. O gerente geral formado em Contabilidade e em Administração Hoteleira, tem 33 anos de experiência em hotelaria e foi o entrevistado na pesquisa. O organograma característico da empresa é o seguinte:

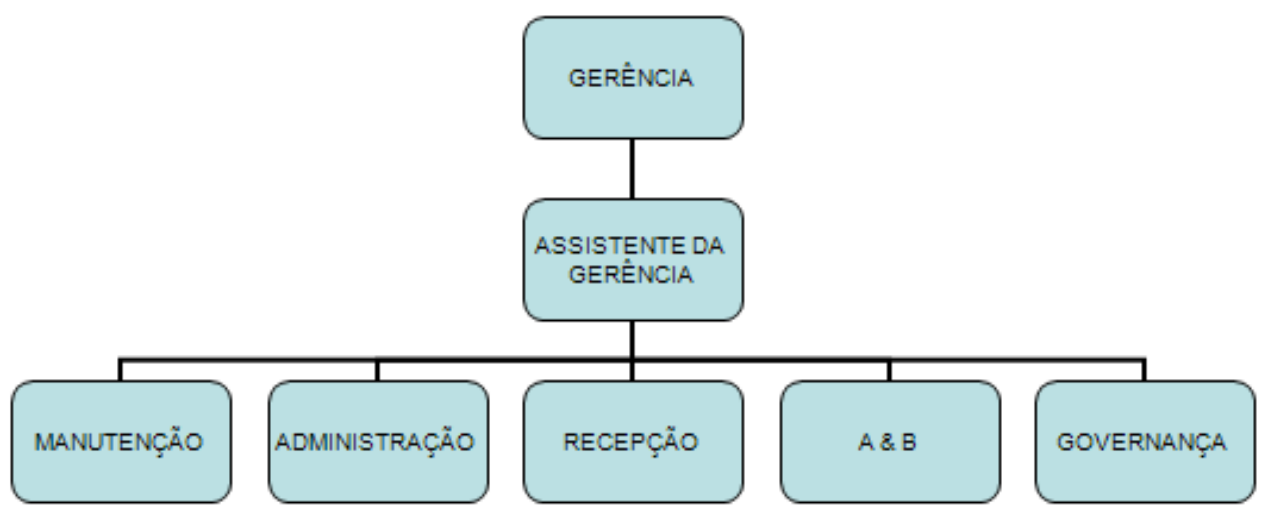

Figura 6.6: Organograma do HOTEL E 
Nas duas unidades são oferecidos serviços de café-da-manhã e área de lazer e estão implantando um SPA na organização.

\subsubsection{HOTEL F}

O HOTEL F é uma empresa familiar que possui três irmãos em diferentes cargos gerenciais. A empresa fundada em 1994 é pequena com relação ao número de funcionários (32) e possui 50 unidades habitacionais. A empresa é administrada pelos três irmãos sócios-gerentes: uma assistente social, uma nutricionista e um zootecnista. O entrevistado, formado em zootecnia, possui 15 anos de experiência na área hoteleira. O organograma do HOTEL F está representado na figura 6.7.

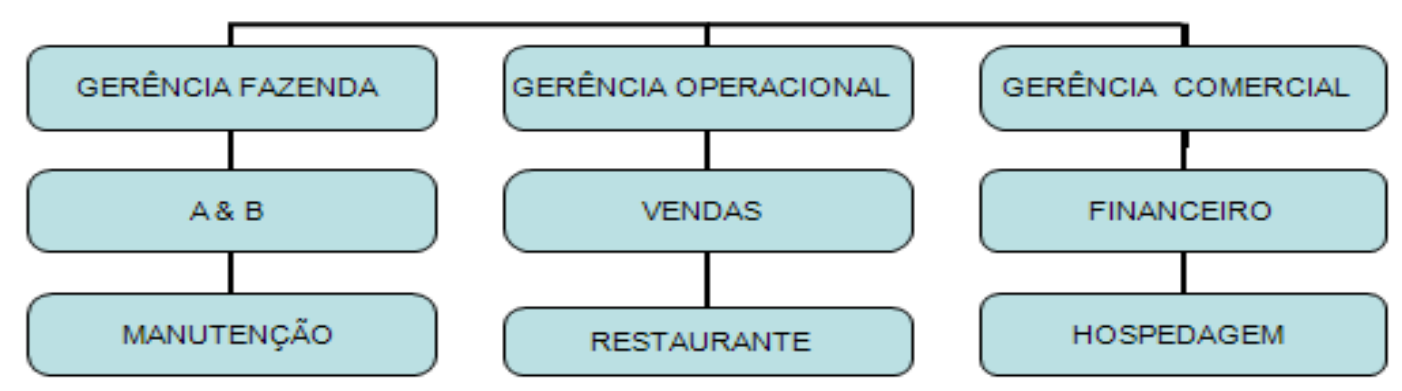

Figura 6.7: Organograma do HOTEL F

A empresa encontra-se em uma fazenda e possui como atrativos: passeios a nascentes de água límpida; mini campo; passeio a cavalo; salão de jogos; sala de convenções; restaurante; quadra de tênis, dentre outras. Os clientes são pessoas físicas e pessoas jurídicas que procuram o hotel pelos motivos de lazer, aventura e negócios.

\subsubsection{HOTEL G}

Considerado como uma organização voltada para o emagrecimento e lazer, a organização pesquisada é um SPA. A organização fundada em 1999 conta com 50 unidades habitacionais e 24 funcionários em um local com vista exuberante, privilegiada e de clima agradável. É considerada uma empresa familiar dirigida pelos dois sócios proprietários, que também são dirigentes da organização e que desempenham funções administrativas e estratégicas. A entrevistada foi a sócia/dirigente da organização, formada em administração, e com 10 anos de 
experiência na área hoteleira. O organograma da organização está distribuído da seguinte forma:

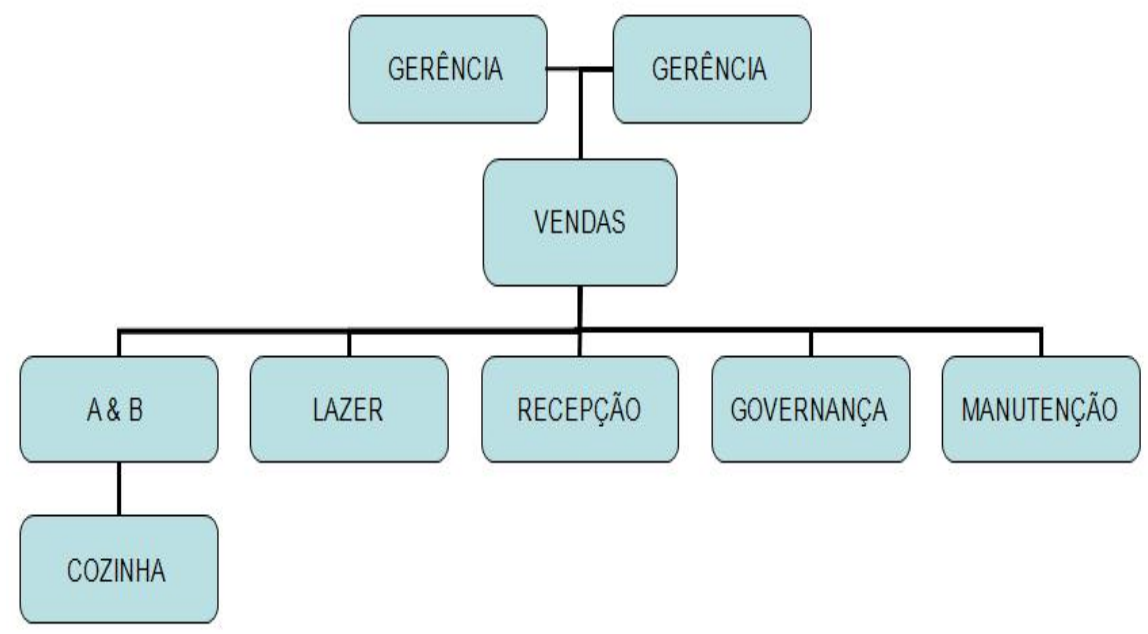

Figura 6.8: Organograma do HOTEL G

Como diferencial a organização oferece serviços de room service, cardápios diferenciados, academia, serviços de estética e nutricionista. Por se tratar de um SPA, apresenta características diferentes dos outros tipos de meios de hospedagem, sendo voltado para descanso e emagrecimento. Ginástica, hidroginástica, dança de salão, alongamento, caminhadas, cine SPA, música ao vivo, videokê, cama elástica, vôlei, tratamentos corporais e de beleza, relaxamento ou terapias alternativas, banhos, caminhadas, bingo, miniboates e tênis de mesa são algumas das atividades oferecidas no local. 


\section{APRESENTAÇÃO E ANÁLISE DOS DADOS}

Este capítulo tem como propósito evidenciar as principais características levantadas com a pesquisa empírica, tendo por base os conceitos abordados na revisão teórica, e apresentar a descrição prática sobre a medição de desempenho organizacional das pequenas e médias empresas.

\subsection{HOTEL A}

Segundo o entrevistado do HOTEL A, a estratégia da organização é oferecer a melhor custo/benefício do que outros hotéis da mesma categoria, atendendo as necessidades e oferecendo conforto aos seus clientes. A estratégia organizacional do HOTEL A ocorre de cima para baixo; é estabelecida pela diretoria da rede. O fato de a organização aderir à estratégia do melhor custo/benefício do mercado está relacionado em oferecer qualidade no atendimento, no apartamento impecável e na agilidade no atendimento na qual o cliente tem conforto com custo baixo. No HOTEL A, a estratégia orienta toda a organização e é a mesma em todas as unidades da rede, pois a preocupação da rede é manter o padrão sempre atualizado.

O entrevistado também afirmou que a estratégia é explicitada, formalizada e declarada aos colaboradores através das reuniões realizadas na organização e através dos treinamentos. A ação dos colaboradores é orientada pela estratégia através do treinamento oferecido pela rede que faz parte do currículo base e através das visitas dos colaboradores em outros hotéis para verificar como é outro hotel, para analisar a concorrência. Também, existem estratégias resultantes das atividades diárias de negócio, mas a estratégia da organização é planejada, pois tenta-se antecipar com o que pode acontecer.

No HOTEL A, os objetivos servem como referência para produzir melhores resultados e são desdobrados em todos os níveis organizacionais. O entrevistado disse 
que quando um colaborador entra na organização lhe é apresentado os objetivos organizacionais. Esses objetivos são transmitidos através das reuniões setoriais para ver como está o andamento do setor e o que pode ser melhorado.

Em relação ao planejamento, o entrevistado afirmou gastar muito tempo com planejamento. Para ele, o planejamento determina o que e como a organização deve fazer. Como exemplo, durante o ano é feito um orçamento anual (budget) pela diretoria central para o estabelecimento de algumas metas organizacionais. No início de todo ano, os gerentes de todos os hotéis da rede recebem um Contrato de Gestão com as metas, percentuais qualitativos e quantitativos que devem ser cumpridos. Esse contrato é gerado com base nos relatórios mensais de cada unidade, que contêm informações sobre o desempenho de todos os departamentos. Na organização também utiliza-se como ferramenta de planejamento estratégico o setor de marketing, planeja-se em termos de receita e despesa, e há um acompanhamento de alguns departamentos que lidam diretamente com o hóspede.

Através do cumprimento das metas estabelecidas pela diretoria, o HOTEL A gratifica todos os colaboradores chegando até três salários para os gerentes e um para os demais colaboradores. Um ponto afirmado pelo entrevistado é da gratificação também ser uma maneira de motivar os funcionários em favor dos objetivos organizacionais e manter o controle na organização. As práticas de gestão do gerente-geral influenciam o comportamento dos colaboradores criando um clima informal na organização, desde o tratamento do hóspede até com o colaborador. Para ele, a organização tem a formalidade da rede que precisa ter, mas o ambiente informal é evidente desde o relacionamento do gerente geral com os funcionários até o uniforme dos colaboradores.

No HOTEL A, foi observado à preocupação com o controle, pois todas as metas estabelecidas pela diretoria são transformadas em padrões de controle. A organização tem metas de diminuir o turnover (rotatividade de colaboradores), garantir a satisfação dos clientes, manter/elevar a satisfação dos colaboradores, garantir que todas as ligações telefônicas dos clientes sejam atendidas dentro do padrão da rede, assegurar treinamento e desenvolvimento dos colaboradores, garantir boa gestão de $\mathrm{A} \& \mathrm{~B}$, assegurar o cumprimento dos procedimentos de autocontrole através do gerenciamento administrativo padrão, zelar pelo patrimônio em bom estado de conservação e aprimorar a gestão e resultados. A organização também segue alguns procedimentos que a certificação de qualidade da ISO 9000 estabelece. Contudo, o 
entrevistado disse que um fator determinante para manter o controle na organização é a pesquisa de satisfação dos hóspedes.

As metas organizacionais são certificadas conforme o estabelecido através da satisfação do hóspede e no acompanhamento diário em todos os departamentos e nas reuniões quinzenais e mensais do gerente-geral com os colaboradores. O entrevistado afirmou realizar visitas diárias aleatórias em sete apartamentos para fazer uma inspeção de qualidade imposta pela rede. Em relação a satisfação do cliente, a organização se baseia no Custome Care, um portal que o cliente envia sua reclamação por e-mail para ser analisada.

A organização acompanha e avalia o desempenho das pessoas, grupos e da própria organização. De acordo com o entrevistado, o cliente é fator primordial e a organização está com uma nova ação de pesquisa de satisfação dos clientes: enviará emails para os clientes, pois encara como positivo o feedback do cliente, mesmo que ele tenha alguma reclamação, pois é uma maneira de corrigir falhas e de melhorar o atendimento.

Até 2008 a organização utilizava o modelo BSC para medir seu desempenho, onde existiam em média trinta itens que eram averiguados junto às unidades o nível de cumprimento das mesmas. A partir de 2008/2009, as ferramentas que eram utilizadas com o BSC continuam existindo, só que foram divididas em auditorias. As medidas de desempenho utilizadas pela organização estão de acordo com as metas estratégicas. Como medidas para avaliar o desempenho, o entrevistado comentou que a organização tem o Cliente Mistério uma vez ao ano, na qual um auditor da ISO fica hospedado para verificar todos os serviços prestados desde o momento da reserva até o check-out (saída). Outra medida apontada é de uma avaliação anual $(A A D D)$ realizada com todos os colaboradores, consistindo em um formulário com atribuições e características, para verificar como a organização está indo, os pontos fortes e fracos. A organização também conta com um portal da rede onde o colaborador pode colocar suas sugestões e na qual a organização realiza uma pesquisa de clima organizacional com os colaboradores para saber como eles se sentem através de algumas perguntas.

Para o entrevistado, os indicadores de desempenho utilizados pela organização são congruentes com o setor hoteleiro da região, pois acredita que os hotéis de rede se preocupam com indicadores financeiros e não-financeiros, enquanto em hotéis familiares é mais difícil. 
O entrevistado disse que não acredita que as práticas de medição de desempenho das grandes organizações diferem das pequenas e médias. Acredita que as grandes organizações usam métodos mais formalizados e que de alguma maneira os pequenos e médios hotéis tentam utilizar, seguir métodos semelhantes das grandes organizações. Afirmou acreditar principalmente em relação à satisfação do hóspede, pois alguns sistemas utilizados na organização são utilizados pelos pequenos e médios hotéis. Um ponto afirmado é que muitos hotéis costumam fazer o feedback, ligam ou enviam um e-mail para saber como foi o atendimento do hóspede.

Para o entrevistado, os grandes hotéis ditam o sucesso do setor hoteleiro pois a região tem uma hotelaria muito caseira: a tarifa da organização é alterada, hotéis da cidade equiparam suas tarifas com a do HOTEL A.

\subsubsection{Estratégia: objetivos e metas estratégicas}

O processo estratégico do HOTEL A é realizado pelo planejamento; o planejamento apresenta ênfase maior no operacional. O processo estratégico é estruturado e os colaboradores da organização sabem exatamente como proceder em relação a ele. Segundo o entrevistado, "a meta é um norte, ela representa o que deve seguir". Nesse sentido, a estratégia é evidenciada como plano, pois as estratégias pretendidas são estabelecidas pela diretoria e servem como um guia ou curso de ação para o futuro da organização. Desde os treinamentos, há preocupação com o comportamento dos funcionários para que ele aja de acordo com a padronização, vital para o gerenciamento de uma grande rede. Ao trabalhar com metas estabelecidas pela diretoria, o HOTEL A não é capaz de atuar de modo flexível, ou seja, suas ações são únicas, ou seja, são as mesmas em todas as unidades. Em relação aos objetivos e metas estratégicas no HOTEL A, eles são transmitidos por escrito e através do contato do gerente geral com os colaboradores durante as reuniões. Nota-se que a estratégia é articulada e não resultante das atividades diárias.

\subsubsection{Controle do Desempenho}

Existe a preocupação com o controle do desempenho. O controle é bem formalizado, as atividades são monitoradas e avaliadas através de padrões, mensurações 
e medidas. O controle na organização pode ser considerado como um controle por resultados; a organização faz uso de critérios de gestão contábeis e não contábeis. Os sistemas de gestão desenvolvidos apresentam sinais de preocupação dos gestores com a ligação entre estratégia, diretrizes, metas e operações e com planos de incentivos ligados aos resultados. No HOTEL A têm-se vários tipos de controles para atingir as metas, como auditorias, contrato de gestão, orçamentos e reuniões. As normas e procedimentos são estabelecidos pela diretoria, mas é o gerente geral quem as transmite para os colaboradores através dos treinamentos realizados pela rede, que segundo o gerente geral, "é uma das maiores ferramentas da organização". Para manter o controle, o HOTEL A conta com os procedimentos de qualidade da ISO 9000, acompanhamento diário nos departamentos, nas reuniões quinzenais e mensais. Além desses controles, uma das preocupações da rede é saber o nível de satisfação do cliente. Dessa maneira, para a correção de desvios e falhas, o HOTEL A se baseia num site de reclamações dos clientes. Como uma ferramenta de controle no departamento de vendas, o HOTEL A tem um cartão fidelidade para o cliente, sendo considerado pelo gerente como "um gancho a mais de vendas", na qual é pontuado todo o consumo do hóspede e revertido em pontos podendo ser utilizado em qualquer hotel da rede. Conclui-se, mesmo com o número reduzido de funcionários, a existência de vários procedimentos de controle do desempenho por ser uma rede hoteleira. Nota-se que no HOTEL A, quanto maior a empresa, mais formalizado é o sistema de controle para garantir a delegação de autoridade.

\subsubsection{Medição de Desempenho}

No HOTEL A, medir o desempenho organizacional é ter o autocontrole da organização. A organização utiliza um modelo formal de medição de desempenho interno, onde existiam em média trinta itens averiguados, divididas em auditorias como: Avaliação de Desempenho (AADD); Auditoria Cliente Mistério (voltado para ISO 9000, onde uma pessoa se hospeda, "testa" os vários serviços do hotel, e no final se apresenta como cliente mistério); Auditoria SFDK - (voltada para área de alimentos e bebidas); Auditoria Autocontrole (auditoria interna da rede, voltada para área administrativa); Auditoria ISO (9000 E 14000); Auditoria de Manutenção (que analisa toda parte de segurança contra incêndio); Visita do gerente operacional; Visita do gerente de alimentos e bebidas da rede; Auditoria Externa (contratada uma auditoria 
para auditar as contas); Índice de Satisfação dos Colaboradores e GPTW (good place to work, realizado junto aos colaboradores da organização).

A medição de desempenho no HOTEL A é associada à estratégia organizacional e é usada para induzir ações e comportamentos dos colaboradores, alinha e comunica a estratégia em todos os níveis organizacionais e é a linguagem da estratégia que instiga os colaboradores à ação e ao favor dos objetivos estratégicos. A organização obtém uma correta medição do desempenho organizacional do ponto de vista estratégico, pois define a estratégia e posteriormente o sistema de medição de desempenho, os indicadores sempre mudam quando há mudanças na estratégia; tanto os indicadores de desempenho como a estratégia, estão alinhados com as metas organizacionais. São enviadas planilhas pela diretoria em como a organização deve ser durante o ano; é preciso gerir a organização conforme o orçamento através dos indicadores de medição de desempenho.

\subsubsection{Indicadores de Medição de Desempenho}

Os indicadores de medição de desempenho do HOTEL A são precedidos pela escolha da estratégia e da estrutura organizacional e são definidos pela diretoria e repassados ao gerente geral que os operacionaliza. Como principais indicadores de medição de desempenho têm-se: Turnover (rotatividade dos colaboradores); GPTW (good place to work); treinamento e desenvolvimento dos colaboradores; Cartas de reclamação; Resavision (garantia que mais de $65 \%$ das ligações telefônicas sejam atendidas dentro do procedimento); Ratio (Mercadoria Consumida); GAP e Autocontrole (assegurar o cumprimento dos procedimentos de autocontrole através do gerenciamento administrativo padrão); PMP (Plano de manutenção preventiva) e a taxa de transformação (GOI). A organização também conta com indicadores financeiros, como vendas, marketing, receita, despesas, taxa de ocupação, diária média e despesas em informática. Desse modo, os indicadores estabelecidos pela diretoria são um padrão de controle do desempenho e de medição de desempenho, que trilham o caminho do gerente e de toda a organização. Conclui-se que os indicadores são importantes no HOTEL A; importantes ao planejamento, pois possibilitam o estabelecimento de metas quantificáveis e o seu desdobramento em todos os níveis organizacionais, e são essenciais ao controle do desempenho, pois os resultados apresentados através dos indicadores fornecem uma analise crítica do desempenho da organização, para as 
tomadas de decisões e para o replanejamento. Nos níveis mais elevados da estrutura organizacional, os indicadores, bem como as metas em geral, são fortemente relacionados aos objetivos e estratégias da organização. Á medida que são desdobrados por meio dos níveis hierárquicos, os indicadores e metas tornam-se mais influenciados pelos indicadores e metas do nível superior, embora não se deva perder de vista os objetivos e estratégias. Conclui-se que os indicadores de medição de desempenham priorizados pela organização têm o aspecto quantitativo (traduz diretamente os resultados), aspecto qualitativo (retrata os resultados mais subjetivos que precisam de escalas comparativas para serem analisados) e retratam o aspecto comportamental (analisa as atitudes e posturas de indivíduos e grupos).

\section{2 HOTEL B}

Além de ser um hotel, o HOTEL B também é um hotel-escola, uma instituição de ensino. A estratégia da organização é ser referência em todos os requisitos tanto de uma instituição de ensino como uma organização hoteleira que preza pelo luxo, serviços, formação de pessoal e atendimento ao hóspede e na qual orienta a ação de todos os participantes. A estratégia ocorre de cima para baixo e define as ações e direcionamentos a serem seguidos, e ainda está intrinsecamente relacionada à competição: ser referência nacional perante seus concorrentes.

Um ponto destacado durante a entrevista, é que o aprendizado pode virar uma estratégia, um padrão dentro da organização porque além de ser um hotel também é uma instituição de ensino. De acordo com o entrevistado, a principal preocupação da diretoria é a forma pela qual a organização vai operacionalizar os alunos dentro do hotel e não necessariamente com os hóspedes. Também existem estratégias resultantes do dia a dia como da relação da organização com seus clientes de oferecer, por exemplo, um cardápio ou um final de semana diferenciado.

$\mathrm{Na}$ organização, se gasta muito tempo com o planejamento. O entrevistado disse que o planejamento determina o que e como a organização deve fazer porque durante o ano é feito um orçamento anual (budget) chamado de $A P T U$, sua ferramenta de planejamento, feito pela gerência na qual é projetada toda a operação para o ano seguinte. Esse budget é transmitido para o coordenador dos hotéis e é discutido 
juntamente com o gerente geral que chegam a consenso e posteriormente é enviado para cima para a aprovação. O subgerente afirmou também utilizar planilhas que o guiam.

As metas e objetivos estabelecidos pela diretoria são escritos, explicitados e declarados em todos os níveis hierárquicos, na qual existe um documento que a organização recebe com as metas que devem ser cumpridas. $\mathrm{O}$ entrevistado afirmou que como a organização é um hotel e também uma instituição de ensino, ela é meio pública e meio particular. Pública porque recebe valores do comércio que são repassados para os colaboradores e particular porque recebe valores pagos pelo hóspede.

O entrevistado acredita que os objetivos da organização servem para produzir melhores resultados porque como a organização tem hóspedes cada vez mais seletos, com necessidades diferenciadas, é preciso investir. Investindo, a organização oferece qualidade, e com esse tipo de hóspede é o que possibilita o HOTEL B ter alunos para o aprendizado. Desse modo, possibilitando que os alunos tenham esse aprendizado, a organização consegue ser referência.

No HOTEL B, existe a preocupação com o controle. A organização monitora seu progresso em direção aos objetivos estabelecidos através de planilhas. $\mathrm{O}$ entrevistado disse que algumas metas são abertas a discussões com todos os colaboradores e ainda são realizadas reuniões semanais da gerência, coordenadores e chefes e a cada trimestre ou bimestre com os funcionários de cada setor. Também disse que além dessas reuniões, existem as reuniões da ISO, das auditorias e de alguns comitês. Além do orçamento anual, mensalmente a organização realiza reuniões para acompanhar se esta atingindo o orçamento traçado no ano anterior. Como metas organizacionais, têm-se: metas de qualidade da ISO 9000, satisfação dos clientes, qualidade, número de hóspedes, taxa de ocupação, lucro, departamento de $\mathrm{A} \& \mathrm{~B}$ e colaborador. Para manter o controle do desempenho, além das metas estabelecidas, o colaborador é motivado com o ambiente de trabalho harmonioso. A organização não bonifica financeiramente seus colaboradores, mas existem bolsas de estudo oferecidas aos colaboradores que atingem os resultados estabelecidos.

O serviço da organização não é tão padronizado quanto outros hotéis como os de rede, para o entrevistado as medidas são diferentes. A organização utiliza um modelo interno de medição de desempenho, acompanha e avalia o desempenho das pessoas, grupos e dela mesma. Como principal ferramenta de medição de desempenho, a organização conta com as pesquisas de satisfação respondidas pelos hóspedes que tem sido uma ferramenta útil também para o cumprimento de metas. $\mathrm{O}$ entrevistado disse 
que a organização também conta com os e-mails enviados no "Fale Conosco" na qual o hóspede pode deixar elogios ou críticas na qual acredita ser uma maneira de corrigir os desvios encontrados na organização.

O subgerente acredita que os indicadores adotados pela organização são congruentes com a estratégia organizacional através dos resultados alcançados e dos resultados da auditoria da ISO. Ainda , os indicadores utilizados pela organização forma apontados como congruentes com os requisitos de competitividade do setor hoteleiro porque eles são absolutamente alinhados com os que a hotelaria no mesmo nível utiliza. $\mathrm{O}$ entrevistado também afirmou que deve-se considerar que muitos dos indicadores da organização são muitas vezes mais educacionais do que hoteleiros. Muitas vezes têm-se indicadores da parte educacional como, por exemplo, o nível de satisfação do aluno e a quantidade de alunos que refizeram a matrícula de um semestre para o outro.

Para o entrevistado, os pequenos e médios hotéis tentam utilizar alguns indicadores de medição de desempenho e controle do desempenho das grandes organizações e ainda acredita que a prática para medir o desempenho seja muito parecida até pela organização não adotar nenhum modelo formalizado e ser uma grande fornecedora de mão-de-obra. Para ele, a organização é muito importante na região; é uma empresa que traz alunos, hóspedes, movimenta os turistas, realiza algumas manutenções na cidade, além de ser formador de mão-de-obra para esses hotéis.

Em relação aos indicadores de medição de desempenho do hotel ser congruente com os fatores de sucesso do setor hoteleiro da região, o entrevistado disse não vê muita relação. Para ele, os resultados da diária média e a taxa de ocupação podem ter alguma correlação porque a organização realiza algumas pesquisas, mas o setor hoteleiro da região apresenta uma hotelaria de micro e pequenos hotéis, diferentemente do HOTEL B. Foi apontado que a organização não se espelha em outros hotéis até porque a organização é também uma instituição de ensino. O entrevistado afirmou que o HOTEL B dita os fatores críticos de competitividade do setor hoteleiro pois como tenta ser uma referência, os pequenos e médios hotéis tentam se espelhar nele.

\subsubsection{Estratégia: objetivos e metas estratégicas}

No HOTEL B, o planejamento é formalizado com a valorização de normas técnicas. Os níveis hierárquicos atuam de maneira altamente formalizada, na qual as ações gerenciais da organização alimentam um planejamento formal de toda a 
organização. Os objetivos e metas estratégicas do HOTEL B a serem cumpridas pela organização são transmitidos por escrito e através do contato com os colaboradores durante as reuniões. A orientação estratégica no HOTEL B ocorre de baixo para cima e nota-se que a estratégia é articulada, e não resultante das atividades diárias, pois está presente nos hábitos organizacionais. A estratégia caracteriza-se como posição, pela busca do reconhecimento da organização em ser referência, considerada a própria estratégia organizacional. Evidencia-se, desta forma, que a estratégia do HOTEL B define as ações e direcionamentos a serem seguidos, e ainda está intrinsecamente relacionada à competição: ser referência nacional perante seus concorrentes.

\subsubsection{Controle do Desempenho}

No HOTEL B existe a preocupação em manter o controle do desempenho. $\mathrm{O}$ controle é bem formalizado, as atividades são monitoradas e avaliadas através de padrões, mensurações e medidas. O controle é burocrático, pois há uma elevada centralização e formalização de procedimentos. A estrutura hierárquica apresenta um grande número de chefias, distribuídos hierarquicamente, mas com pouco grau de autonomia. $\mathrm{Na}$ abordagem tradicional de cima para baixo, o gerente geral e subgerente exercitam sua autoridade formal para realizar mudanças. No HOTEL B as metas também funcionam como um padrão de controle do desempenho, existindo uma série de processos e procedimentos para se chegar aos percentuais estabelecidos pela diretoria. Além de um budget (orçamento) anual, mensalmente a organização realiza reuniões para acompanhar se esta atingindo o orçamento traçado no ano anterior. Existem também normas que fazem parte do dia-a-dia no HOTEL B e que segundo o entrevistado "não são questionáveis, é preciso cumpri-las". Nota-se que, no HOTEL B, tende-se a uma maior descentralização e a utilização de sistemas de controle financeiro orientados à gestão de resultados.

\subsubsection{Medição de Desempenho}

No HOTEL B, mesmo sendo considerado como uma grande empresa, o serviço da organização não é tão padronizado quantos outros hotéis do mesmo porte; as medidas de desempenho são diferentes. A organização utiliza um modelo de medição de desempenho interno, desenvolve instrumentos de medição que colaborem com o 
processo de tomada de decisões, avaliando sua eficácia e eficiência. A organização prioriza a perspectiva dos clientes e considera como a principal ferramenta de medição de desempenho as pesquisas de satisfação respondidas pelos hóspedes. Para a organização, avaliar o nível de satisfação do hóspede é uma maneira da organização medir seu desempenho. Embora não utiliza um modelo formalizado, a medição de desempenho é centralizada na estratégia e é usada para induzir ações e comportamentos, sendo primordial para alinhar e comunicar a estratégia. A organização obtém uma correta medição do desempenho organizacional do ponto de vista estratégico, pois define a estratégia e posteriormente o sistema de medição de desempenho; os indicadores sempre mudam quando há mudanças na estratégia; tanto os indicadores de desempenho como a estratégia, estão alinhados com as metas organizacionais.

Conclui-se que a medição de desempenho no HOTEL B é alinhada na estratégia da organização e é usada para induzir ações e comportamentos dos colaboradores, alinha e comunica a estratégia em todos os níveis organizacionais; é a linguagem da estratégia que instiga os colaboradores à ação e ao favor dos objetivos estratégicos.

\subsubsection{Indicadores de Medição de Desempenho}

No HOTEL B os indicadores de medição de desempenho são precedidos pela escolha da estratégia e da estrutura organizacional. Os indicadores de medição de desempenho são definidos pela diretoria e repassados ao gerente geral e subgerente que os operacionaliza. Como principais indicadores de medição de desempenho adotados pela organização têm-se: taxa de ocupação; diária média; revpar (receita por apartamento disponível); satisfação do hóspede; CMV (custo de mercadoria vendida); levantamento de quanto à organização está tendo de prejuízo; percentual de aprovação do hóspede para reposição do Buffet; e percentual do serviço do bar. Também têm-se indicadores financeiros como de receita, lucro e folha de pagamentos. Assim como no HOTEL A, nos níveis mais elevados da estrutura organizacional, os indicadores, bem como as metas em geral, são fortemente relacionados aos objetivos e estratégias da organização. Á medida que são desdobrados na estrutura organizacional, os indicadores e metas tornam-se mais influenciados pelos indicadores e metas do nível superior, embora não se deva perder de vista os objetivos e estratégias. Conclui-se que os indicadores de medição de desempenho priorizados pela organização têm o aspecto 
quantitativo (traduz diretamente os resultados), aspecto qualitativo (retrata os resultados mais subjetivos que precisam de escalas comparativas para ser analisados) e retratam o aspecto comportamental (analisa as atitudes e posturas de indivíduos e grupos).

\subsection{HOTEL C}

A estratégia da organização é oferecer qualidade e serviços de excelência. A orientação estratégica é fazer com que o hóspede fique dentro do hotel e aproveite todos os serviços oferecidos. De acordo com o entrevistado e gerente-geral, o ambiente do HOTEL C é informal porque além de ser um hotel de médio porte não tem metas formalizadas que pressionam o colaborador.

A orientação estratégica no HOTEL C ocorre de cima para baixo e orienta toda a organização. O entrevistado atua como elo intermediador com o diretor porque ele não está diretamente relacionado com as decisões estratégicas da organização, mas sim com as decisões financeiras. A estratégia é explicitada e declarada aos colaboradores através das reuniões realizadas na organização. Além da reunião anual que ocorre em outubro, existem outras reuniões para verificar se as metas estão conforme o estabelecido. A cada 15 dias, é realizada uma reunião entre as chefias de todos os departamentos para avaliar como foram os 15 dias passados, como a taxa de ocupação e gastos, e toda semana cada chefe de departamento se reúne com sua equipe e transmite as metas da organização.

A estratégia da organização é planejada, mas também existem estratégias resultantes das atividades diárias da organização, pois cada vez mais tenta-se melhorar os serviços através das atividades resultantes do dia a dia. Para o entrevistado, os objetivos servem como referência para produzir melhores resultados e são desdobrados em todos os níveis organizacionais.

O entrevistado afirmou gastar muito tempo com planejamento. Para ele, o planejamento determina o que e como as coisas devem ocorrer dentro da organização. Além de lidar com o planejamento anual realizado nas reuniões em outubro, costuma planejar-se diariamente. Todo mês de outubro, o gerente geral reúne-se com sua equipe e planeja toda a programação do próximo ano e no terceiro dia da reunião são submetidas ao diretor as metas organizacionais para aprovação. A organização monitora seu progresso em relação aos objetivos estabelecidos, através de algumas metas como da cozinha, satisfação do cliente, governança e departamento de vendas. Ainda, tem metas como das serestas e jantares. 
Através do cumprimento das metas estabelecidas a organização gratifica seus colaboradores, vista como uma maneira de motivar os colaboradores em favor dos objetivos organizacionais e de manter o controle na organização. Quando há a consecução da meta, o gerente-geral costuma comprar um bolo, um chocolate para o grupo e ainda existe o melhor funcionário do mês. Contudo, para o entrevistado, o departamento de vendas é o veículo viabilizador da organização para depois haver a preocupação com outros departamentos para o estabelecimento de metas.

No HOTEL C, existe a preocupação com o controle, pois todas as metas estabelecidas são transformadas em padrões de controle. Na organização existem metas padronizadas, mas não tão detalhadas como em grandes organizações. Certifica-se que a meta da organização está sendo alcançada, por exemplo, através do formulário de satisfação do hóspede, que ao ser avaliado a organização também mede seu desempenho. A organização também conta com serviços de ligações para os hóspedes para manter sua fidelidade e também a recepção deve seguir um procedimento no atendimento ao telefone.

O entrevistado disse que a organização acompanha e avalia o desempenho das pessoas, grupos e da própria organização. A organização não utiliza nenhum modelo formalizado de medição de desempenho, mas utiliza um sistema operacional hoteleiro que possibilita verificar o setor de vendas, check-in (entrada) e check-out (saída), compras e custos, na qual somente o gerente-geral tem contato com essas planilhas dos resultados que posteriormente são transmitidas ao diretor nas reuniões. Para medir o desempenho dos colaboradores, como da recepção, o entrevistado utiliza práticas informais: pede para alguém ligar na organização a cada quinze dias para saber como está sendo feito o atendimento, avalia o desempenho organizacional através das cortesias que oferece a algumas pessoas para passarem o final de semana, avalia e acompanha o desempenho dos chefes de departamentos nas reuniões, pois procura observar o comportamento, a postura e quais serviços estão sendo bem feitos. $\mathrm{O}$ entrevistado disse que a organização também realiza pesquisas de mercado para avaliar seus concorrentes e serviços oferecidos a cada seis meses, na qual o departamento de vendas verifica a tarifa e serviços oferecidos dos concorrentes e passa um feedback para a ele.

Como principais indicadores de medição de desempenho, são destacados a satisfação dos clientes, vendas, taxa de ocupação e a diária média. O entrevistado disse que acredita que seus indicadores são congruentes com os objetivos e metas estratégicas 
da organização e também são congruentes com os requisitos de competitividade do setor hoteleiro porque sua taxa de ocupação, por exemplo, é superior a de outros hotéis da região. Afirmou que também conta com um serviço de telemarketing, um indicador de potencial para captar clientes e parcerias com agências.

$\mathrm{O}$ entrevistado afirmou que acredita que de alguma maneira as pequenas empresas usam princípios de administração semelhantes aos da organização até pelo HOTEL C não ter ferramentas e modelos formalizados de medição e pela informalidade em alguns procedimentos. Acredita que os indicadores dos grandes hotéis são viáveis nos pequenos e médios hotéis, pois a busca pelo desempenho é o mesmo e o uso de indicadores podem ser os mesmos, a única diferença é que a prática nas pequenas organizações é mais informal.

O gerente-geral não acredita que os grandes hotéis da região ditam os fatores críticos de sucesso da hotelaria, pois segundo ele, nos dois anos em que está na cidade, a organização conquistou vários hóspedes de um hotel de grande porte. Para ele, o diferencial da organização é de não ser um hotel fechado, o hóspede tem liberdade e está próximo ao comércio, as atrações turísticas da cidade.

\subsubsection{Estratégia: objetivos e metas estratégicas}

No HOTEL C o planejamento é formalizado. A estratégia é um plano porque a organização lida com um planejamento anual de acordo com o entrevistado "planejo as coisas de cabeça". Nota-se que a estratégia é resultante das atividades diárias da organização, pois segundo o gerente geral "cada vez mais tentamos melhorar nossos serviços através das atividades resultantes do dia-a-dia”.

Conclui-se que no HOTEL C existe um planejamento formalizado, prévio de toda a programação anual do hotel e metas a serem atingidas. No entanto, conta com uma estratégia não formalizada, decorrida das atividades diárias do negócio. A informalidade no HOTEL C deve-se ao tamanho reduzido do hotel e da sua gestão. A estratégia é orientada em oferecer qualidade e serviços de excelência, na qual determina a ação dos colaboradores para o atingimento das metas e objetivos organizacionais. 


\subsubsection{Controle do Desempenho}

No HOTEL C existe a preocupação em manter o controle do desempenho, embora um controle informal. As atividades são monitoradas e avaliadas informalmente através da análise dos resultados da organização. Para manter o controle organizacional o HOTEL C conta com metas estabelecidas pelo gerente geral e é feita uma inspeção da governanta nos quartos para manter a qualidade no serviço oferecido. Existem ainda metas de satisfação do colaborador na qual a organização também conta com serviços de ligações para os hóspedes para manter sua fidelidade. Nota-se que a organização tem uma gestão centralizada na direção e uma limitada ênfase em mecanismos de controle formais, pois somente o departamento de vendas tem metas; pode ser considerado como um controle centralizado na direção, seletivamente formal. O gerente geral delega autonomia aos chefes de departamento, mas de maneira limitada. A gerência se baseia em mecanismos de controle informais, através da liderança e delegação de autoridade.

\subsubsection{Medição de Desempenho}

A organização não utiliza nenhum modelo de medição de desempenho formalizado, mas desenvolvem instrumentos de medição que colaborem com o processo de tomada de decisões, avaliando sua eficácia e eficiência. A organização prioriza a perspectiva dos clientes e de seus colaboradores, pois de acordo com o entrevistado "se o colaborador não está satisfeito, ele não pode atender com qualidade meu cliente, que por sua vez afeta o nível de vendas". Para medir o desempenho dos colaboradores, o entrevistado utiliza técnicas informais. Práticas informais como as do HOTEL C são uma maneira de monitorar o progresso da organização em relação aos objetivos como um todo, característico de seu porte.

\subsubsection{Indicadores de Medição de Desempenho}

No HOTEL C os indicadores de medição de desempenho são precedidos pela escolha da estratégia e da estrutura organizacional. Os indicadores de medição de desempenho são definidos pelo gerente geral e repassados aos chefes de departamento que os operacionaliza. Como principais indicadores de medição de desempenho adotados pela organização têm-se: satisfação do cliente; vendas; serviço de 
telemarketing; taxa de ocupação e a diária média. Conclui-se que nos níveis mais elevados da estrutura organizacional, os indicadores, bem como as metas em geral, são fortemente relacionados aos objetivos e estratégias da organização. A medida que são desdobrados nos níveis hierárquicos, os indicadores e metas tornam-se mais influenciados pelos indicadores e metas do nível superior, embora não se deva perder de vista os objetivos e estratégias. Conclui-se que os indicadores de medição de desempenho priorizados pela organização têm o aspecto quantitativo (traduz diretamente os resultados) e retratam o aspecto comportamental (analisa as atitudes e posturas de indivíduos e grupos).

\section{4 HOTEL D}

A estratégica do HOTEL D é oferecer serviço de qualidade e ser referência no atendimento do cliente. A orientação estratégica na organização é de solucionar as necessidades dos clientes, sendo explicita e declarada durante as reuniões com os colaboradores e transmitida com a intenção que todos os colaboradores trabalhem em cima dos objetivos organizacionais. A estratégia reside na mente de todos os colaboradores e também é escrita, pois existe um documento com as metas e objetivos, sejam anuais ou mensais.

A organização também planeja seus objetivos e metas. Os objetivos servem como referência para produzir melhores resultados e são desdobrados em todos os níveis organizacionais: são transmitidos aos colaboradores informalmente e durante as reuniões realizadas mensalmente. A cada 15 dias, o subgerente, o diretor e o gerente operacional se reúnem para traçar algumas metas e objetivos. De acordo com o entrevistado é com os objetivos traçados e com o planejamento que a organização trabalha em cima do que pretende.

A organização não utiliza nenhuma ferramenta de planejamento estratégico. $\mathrm{O}$ entrevistado também disse que gasta muito tempo com planejamento. Para ele, o planejamento determina o que e como a organização deve fazer. No HOTEL D há um planejamento traçado do que deve ser feito como de verificar as despesas, compras e contratação, mas também tem um planejamento diário, praticamente todos os dias são iguais. 
A organização não trabalha com gratificações financeiras, mas tem como objetivo começar a gratificar, reconhecer financeiramente seus colaboradores. Para o entrevistado, com a gratificação financeira o colaborador vai se preocupar em fazer o serviço cada vez melhor e será uma estratégia para também manter o controle na organização.

No HOTEL D existe a preocupação com o controle do desempenho. Algumas metas e objetivos são de longo prazo e dessa maneira, são verificadas pelo menos duas vezes ao mês antes de acontecer. As metas estratégicas são transformadas em padrões de controle e de definição de prioridades como de investimentos na organização. $\mathrm{O}$ progresso da organização é monitorado através da satisfação do hóspede, dos colaboradores, através dos resultados gerados de um programa de computador (planilha). Diariamente busca acompanhar tudo dentro do estabelecido. As metas organizacionais são padronizadas, mas não tão detalhadas como em grandes hotéis. Como principais metas, a organização prioriza o estoque, faturamento, taxa de ocupação, satisfação dos clientes, vida útil dos equipamentos e despesas. $\mathrm{Na}$ área financeira, tem-se a ampliação física e de pessoas.

A organização utiliza um modelo próprio de medição de desempenho. No HOTEL D, o gerente-geral é quem acompanha e avalia o desempenho das pessoas, grupos e da própria organização. Um fator apontado pelo entrevistado como primordial para avaliar o desempenho organizacional é a satisfação do cliente e seu feedback. Uma maneira de avaliar essa satisfação é através do check-out (saída), através de uma palavra ou gesto que o hóspede transmite de satisfação ou insatisfação. $O$ dirigente espera aprimorar sua avaliação subjetiva dos clientes pela contratação de uma consultoria. Já para medir a satisfação do colaborador, é através do contato diário, na qual o gerentegeral procura observar e conversar com todos. O entrevistado disse que tem dificuldade em acompanhar muitas coisas na organização, pois ele não tem quem faça isso. No entanto, a organização está com uma nova ação chamada de "Programa de Comprometimento", uma ferramenta para avaliar e medir o desempenho dos colaboradores como atendimento ao hóspede.

Como principais indicadores de medição de desempenho utilizados pela organização têm-se: taxa de ocupação, faturamento, quantidade de hóspedes conquistados e satisfação do colaborador. A taxa de ocupação foi apontada, pois está relacionada com o financeiro, ao lucro, porque uma vez que a organização tem uma taxa de ocupação relevante, é automático que ela tenha o faturamento pretendido. A 
satisfação do colaborador também foi apontada porque para o gerente-geral é mais difícil conquistar a satisfação do colaborador do que a do hóspede.

Em relação aos indicadores de desempenho utilizados pela organização serem congruentes com o setor hoteleiro da região, o entrevistado disse que acredita, pois eles caminham juntos; se a organização não conseguir o mínimo de satisfação dos colaboradores a taxa de ocupação tende a cair, é um ciclo. Ao afirmar que seus indicadores não estão congruentes com os requisitos de competitividade do setor hoteleiro, pois acredita que a hotelaria da cidade está mais preocupada em ter lucro e não com a satisfação do cliente, houve uma contradição na resposta do entrevistado.

Em relação aos indicadores de desempenho, o entrevistado disse que acredita que as pequenas organizações utilizam indicadores de desempenho semelhantes das grandes organizações e que podem ser viáveis em empresas de pequeno porte, mas de uma maneira mais informal. Para ele, as grandes organizações tendem a ser mais burocratizadas e precisam de um grande número de indicadores para acompanhar seu desempenho, manter o controle; dificilmente os indicadores das pequenas e grandes empresas são tão diferentes.

O entrevistado não acredita que as grandes organizações da região ditam os fatores críticos de sucesso da hotelaria porque os hotéis da região são muito amadores, tem uma hotelaria muito caseira. Para ele, algumas ações das grandes organizações podem ser referência, mas muitas destas ações existem em outros ramos também. Muitos gestores de pequenos hotéis da região têm a visão rebuscada de hotelaria; para eles investir é em bens materiais e não como em treinamento para o colaborador.

Em relação ao ambiente na qual a organização esta inserida, o entrevistado disse acreditar que o ambiente impõe alguma barreira para o alcance efetivo do controle na organização. Como exemplo, citou parcerias com agências de fomento ao turismo na cidade e afirmou que cada vez está mais está complicado ter o apoio do governo, pois as taxas prejudicam muito o desempenho organizacional. Em relação à questão financeira disse que ela é base de tudo, como, por exemplo, para a contratação de colaboradores mais qualificados

Ao inferir que as pequenas empresas competem com as grandes organizações, o entrevistado disse que ser maior dá mais condições de investimento do que o mercado exige, ou seja, melhor infra-estrutura, equipamentos modernos, funcionários mais qualificados, entre outros. Mas, para ele, ser maior não é ser melhor. Afirmou que o padrão do mercado muda muito e ser maior possibilita ficar no mercado, 


\subsubsection{Estratégia: objetivos e metas estratégicas}

No HOTEL D o planejamento estratégico foi identificado como sendo formal, pois de acordo com o entrevistado os objetivos e o planejamento servem como referência para produzir melhores resultados. A estratégia é evidenciada como um plano pelo do qual se opta por guardar o máximo de lucro para que seja reinvestido na construção de uma nova unidade. Um ponto forte que caracteriza as relações e o comportamento das pessoas é o fato de que o ambiente interno conta com relações muito próximas. Os colaboradores se sentem parte de uma equipe e cumpre suas tarefas da melhor forma possível, fato que justifica o tempo de cada um na organização. O gerente geral consegue fazer um bom uso do papel interpessoal. Em relação às metas e objetivos, o gerente geral os transmite durante as reuniões realizadas mensalmente com os colaboradores. Segundo o gerente geral são transmitidas as metas, mas o foco é ação pró-ativa, de fazer com que o colaborador não continue errando.

\subsubsection{Controle do Desempenho}

No HOTEL D existe a preocupação em manter o controle do desempenho, embora um controle também informal. $\mathrm{O}$ controle ocorre na abordagem tradicional de cima para baixo, embora seja um controle participativo, na qual o gerente geral colabora com os colaboradores na busca da ação corretiva requerida, toma as ações corretivas para mudar os padrões de desempenho. Em relação ao controle do desempenho, o gerente afirma que seu dia a dia é repleto de controle; seu envolvimento é total; tenta utilizar melhor o seu tempo e acredita que a cada dia vai melhorando, pois tenta otimizar as coisas que realiza. As metas estratégicas são transformadas em padrões de controle na organização e de definição de prioridades como de investimentos. É monitorado o progresso da organização em direção aos objetivos estabelecidos através "do que sabe que é preciso fazer" e através das "observações", como afirma o entrevistado. Como ferramenta de controle, a organização se baseia no questionário de satisfação do hóspede, dos colaboradores e da organização como um todo. Nota-se que a organização tem uma gestão muito centralizada e com uma limitada ênfase em mecanismos de controle formais; se baseia em um controle familiar. $\mathrm{O}$ gerente geral (filho do proprietário) realiza o controle com certa delegação, mas com uma limitada descentralização que reduz a necessidade do controle. A organização não atribui muita 
importância aos mecanismos formais. A gerência se baseia em mecanismos de controle informais, através da liderança, centralização nas decisões, delegação de autoridade baseado nas relações familiares.

\subsubsection{Medição de Desempenho}

O HOTEL D prioriza a perspectiva dos clientes e seu feedback é fator primordial para medir o desempenho organizacional. As práticas de medição são muito informais, é verificada a satisfação do cliente no check-out (saída), através de uma palavra ou gesto que ele transmite de satisfação ou insatisfação. Medir a satisfação do colaborador é um mecanismo que ocorre no diariamente, na qual o gerente geral procura observar e conversar com todos. Para avaliar e medir o desempenho organizacional o entrevistado verifica todos os departamentos todos os dias, porque segundo ele "eu não tenho quem faça isso". Em relação à adoção de modelo de medição de desempenho, a organização não utiliza nenhum para avaliar seu desempenho. A avaliação é feita informalmente através do contato diário. O gerente costuma fazer pesquisa de mercado; lê revistas e visita alguns hotéis. A medição de desempenho não é feita em todas as áreas críticas destacadas pelos objetivos organizacionais. Conclui-se a maneira de verificar, medir a satisfação do cliente é bem informal e aponta a falta de uma ferramenta mais concreta e de confiabilidade.

\subsubsection{Indicadores de Medição de Desempenho}

No HOTEL D os indicadores de medição de desempenho são precedidos pela escolha da estratégia e da estrutura organizacional. Os indicadores de medição de desempenho são definidos pelo gerente geral e pelo seu pai diretor/proprietário e são repassados aos demais colaboradores que os operacionaliza. Como principais indicadores de medição de desempenho adotados pela organização têm-se: a taxa de ocupação; garantir a satisfação dos clientes; satisfação do colaborador e o faturamento. Para o HOTEL D os indicadores apontados como mais importantes são congruentes com os objetivos e metas estratégicas, pois eles caminham juntos. Segundo o entrevistado, se a organização não conseguir o mínimo de satisfação dos colaboradores a taxa de ocupação tende a cair, é um ciclo. 


\section{5 HOTEL E}

A estratégica do HOTEL E é vendas. A orientação estratégica é a de não deixar o cliente sair da organização sem ficar hospedado. A estratégica da organização é explícita e declarada a todos; é transmitida através das reuniões semanais com os colaboradores e também é feito pelo gerente-geral um feedback mensal dos problemas da organização na qual são transmitidos para todos trabalhem em cima dos objetivos organizacionais. $\mathrm{O}$ entrevistado disse que a estratégia reside na mente de todos os colaboradores e é estabelecida pelo proprietário que transmite seus ensinamentos à ele. A estratégia organizacional não é escrita, mas existe um documento da forma como os colaboradores devem a fazer funcionar.

A organização planeja seus objetivos e metas. O gerente-geral se reúne com o proprietário em média quatro vezes ao ano para discutir metas, estratégias e fazer o planejamento. Além das reuniões com o proprietário, o gerente-geral também está sempre conversando com o proprietário pela internet. O planejamento é diário e de longo prazo. Para o entrevistado, o planejamento determina o que e como a organização deve fazer. Como exemplo, as tarifas anuais são planejadas e colocadas no site da organização, mas essas tarifas são antes transmitidas ao proprietário. Como ferramenta de planejamento estratégico, a organização utiliza alguns conceitos de um livro da área hoteleira, na qual justifica ser uma ferramenta eficaz.

Os objetivos da organização servem como uma referência para produzir melhores resultados. Como metas, o HOTEL E conta, por exemplo, com gastos e despesas. Como meta, o departamento de governança é também é apontado porque esse setor cuida do principal produto do hotel, o quarto que precisa ser impecável. O entrevistado disse que através do cumprimento das metas estabelecidas, a organização gratifica os colaboradores em $5 \%$ na participação por resultados e aponta como uma estratégia eficaz de motivar o colaborador e manter o controle na organização.

Existe a preocupação com o controle do desempenho na organização. $O$ entrevistado disse que se certifica que a meta da organização está sendo alcançada conforme o estabelecido através do próprio cliente. Diz se basear no questionário de satisfação do cliente que é entregue no check-out (saída). Outra ferramenta utilizada é um programa hoteleiro que calcula seu lucro e despesas. O entrevistado também disse que se baseia muito em que vê porque está em contato direto com tudo. Comenta também ter outros meios como de ligar ou dos próprios familiares dos proprietários 
ligarem na organização como se fossem clientes para verificar o atendimento e depois transmitem para ele.

A organização utiliza um modelo próprio de medição de desempenho e suas medidas de desempenho estão de acordo com as metas estratégicas. Como medidas de desempenho, a organização avalia semestralmente e anualmente o desempenho de cada colaborador dentro dos padrões de qualidade da hotelaria. Ainda, o gerente-geral verifica todas as reservas, ou seja, check-in (entrada) e check-out (saída) juntamente com a fatura do hospede pelo departamento contábil, além de um acompanhamento diário realizado em um sistema hoteleiro chamado "Net Hotel". Para avaliar o desempenho dos grupos, o entrevistado se baseia num relatório de satisfação.

Como principais indicadores de desempenho utilizados pela organização têm-se: taxa de ocupação e os salários dos colaboradores. Para o entrevistado, a taxa de ocupação é o indicador mais importante da hotelaria, pois é a hospedagem que mobiliza a taxa de ocupação e afirma acreditar que esse indicador seja congruente com os objetivos e metas da organização.

Em relação às pequenas empresas competirem com as grandes organizações, o entrevistado acredita que competem, pois ele sempre pensa o que faz uma pessoa se hospedar em um hotel. Para ele, muitos olham o preço e depois o atendimento e dessa forma afirma acreditar que sua suíte compete com a suíte de uma grande organização da cidade e por um preço menor.

Em relação às pequenas empresas usarem princípios administrativos e também de controle e desempenho organizacional semelhantes das grandes organizações, o entrevistado disse que acredita, só que mais informais, por exemplo, não contam com sistemas informatizados hoteleiros. Afirmou que os indicadores de desempenho da organização são congruentes com os indicadores de outros hotéis da região porque no geral os hotéis da região buscam a taxa de ocupação. Em relação aos indicadores das grandes organizações possibilitarem o estabelecimento de metas quantificáveis, o entrevistado acredita que só um grande hotel de rede internacional no Brasil esteja nesse caminho.

Em relação às quais características do setor hoteleiro podem influenciar na escolha dos indicadores do controle do desempenho das grandes organizações, o entrevistado disse que é a taxa de ocupação porque muitas grandes organizações fazem com que o cliente fique hospedado, assim como eles. 
Em relação às práticas de medição de desempenho das grandes organizações, o gerente-geral acredita que as práticas das pequenas empresas diferem um pouco. Acredita que é preciso competir e se a organização não é maior precisa ser a melhor. Afirmou que as práticas são semelhantes e conclui que a pequena organização corre mais atrás dos clientes.

\section{5.1 Estratégia: objetivos e metas estratégicas}

No HOTEL E o planejamento é formalizado. Os colaboradores atuam de maneira formalizada, na qual as ações gerenciais da organização alimentam um planejamento formal de toda a organização. Existe a preocupação com o condicionamento de todos os colaboradores e a estratégica organizacional pode ser considerada como um plano, uma vez que o entrevistado disse "não deixar o cliente sair da organização sem ficar hospedado".

Em relação às metas e objetivos estratégicos, nota-se que a organização tem metas, mas não formalizadas como de grandes organizações. As metas e objetivos estratégicos são transmitidos aos colaboradores semanalmente durante as reuniões do gerente geral com os chefes de departamentos que transmitem aos demais colaboradores.

\subsubsection{Controle do Desempenho}

No HOTEL E existe a preocupação em manter o controle do desempenho. O controle ocorre na abordagem tradicional de cima para baixo, embora seja um controle participativo, na qual o gerente geral colabora com os colaboradores na busca da ação corretiva requerida, toma as ações corretivas para mudar os padrões de desempenho. Nota-se que a organização tem uma gestão centralizada na direção e uma limitada ênfase em mecanismos de controle formais, mas que promovem o autocontrole. $\mathrm{O}$ controle pode ser considerado como centralizado e seletivamente formal, pois a organização somente delega metas ao departamento de vendas. 


\subsubsection{Medição de Desempenho}

O HOTEL E prioriza a perspectiva dos clientes. As práticas de medição são muito informais e a organização não utiliza nenhum modelo formalizado de medição de desempenho. $\mathrm{O}$ entrevistado afirma que verifica se as coisas estão conforme o estabelecido através do "dedo duro", que segundo ele é o próprio cliente. Para medir seu desempenho, a organização se baseia no questionário de satisfação dos hóspedes e através do contato direto. A organização avalia seu desempenho através do "boca a boca", do que as pessoas transmitem, segundo o entrevistado. O entrevistado costuma fazer pesquisa de mercado para ver as práticas de medição de desempenho de outros hotéis e costuma olhar o site de uma grande rede internacional, pois acredita que eles são ótimos em inovar e utilizem modelos de medição formalizados.

\subsubsection{Indicadores de Medição de Desempenho}

No HOTEL E os indicadores de medição de desempenho são precedidos pela escolha da estratégia e da estrutura organizacional. Os indicadores de medição de desempenho são definidos pelo gerente geral e repassados aos chefes de departamento que os operacionaliza. Como principais indicadores de medição de desempenho adotados pela organização têm-se: a taxa de ocupação; lucratividade e salários dos colaboradores. Para o entrevistado, a taxa de ocupação desdobra os demais indicadores como a lucratividade; é a "mola mestre da hotelaria". Conclui-se que os indicadores de medição de desempenho priorizados pela organização têm o aspecto quantitativo (traduz diretamente os resultados), e retratam o aspecto qualitativo (retrata os resultados mais subjetivos que precisam de escalas comparativas para ser analisados)

\section{6 HOTEL F}

A estratégica da organização é a busca de novos clientes. A orientação estratégica do HOTEL F é a de conquistar cada vez mais um maior número de clientes. A estratégia é explicita e declarada nas reuniões semanais realizadas com os chefes de departamentos que transmitem aos demais colaboradores.

A ação dos colaboradores é orientada pela estratégia e é desdobrada em todos os níveis organizacionais. Todos os colaboradores sabem da missão e objetivos organizacionais, na qual são transmitidos através dos treinamentos internos e através do 
contato direto com eles porque muitas coisas não precisam esperar para serem transmitidas no dia da reunião. O entrevistado afirmou que quando um colaborador é contratado é feito um treinamento interno e a organização também conta com uma apostila com as funções de cada departamento que foram elaboradas por uma empresa de consultoria.

Os objetivos da organização servem como referência para produzir melhores resultados. A organização planeja seus objetivos e metas que são estabelecidas pelo entrevistado e pelas outras duas proprietárias/dirigentes, mas quem estabelece a estratégia é o entrevistado, pois está mais envolvido com o todo organizacional. O entrevistado afirmou que ele e as duas proprietárias/dirigentes se reúnem formalmente uma vez ao mês para discutir as metas e objetivos organizacionais. Além das reuniões semanais e mensais, eles também sempre almoçam juntos na qual acabam trocando algumas metas.

O entrevistado afirmou gastar muito tempo com planejamento. Para ele, até hoje o planejamento da organização foi de crescimento. Comentou que seu dia é repleto de planejamento e que costuma planejar seu dia-a-dia e o que vai fazer em determinado dia e a longo prazo. Apontou em seu planejamento as pesquisa de mercado e procura sempre novas estratégias e novos produtos ou maneiras parecidas de fazer a mesma coisa que algum outro hotel faz para implantar na organização.

A organização gratifica os chefes de departamentos que recebem uma porcentagem mensal em cima dos lucros da organização. Segundo o entrevistado, somente agora a organização começou a cobrar a taxa de serviço dos clientes que é revertida para os demais colaboradores. Para ele, foi uma maneira de buscar uma gratificação para os demais colaboradores, uma maneira de motivá-lo pois afirmou que se o colaborador não trabalhar motivado nada funciona na organização. Ainda, afirmou que as gratificações são eficazes para manter o controle e desempenho satisfatório dos colaboradores na organização.

A organização faz o controle do desempenho. O HOTEL $F$ se certifica que a meta da organização está sendo alcançada conforme o estabelecido através do questionário de satisfação dos hóspedes e também através do contato direto dos proprietários. O entrevistado disse acreditar o que está no papel (questionário) já transmite o que ele quer saber e também afirmou que como esta na frente do negócio não tem como não manter o controle na organização. Como metas, a organização conta com, por exemplo, as financeiras de lucratividade e despesas, taxa de ocupação e novos 
produtos. Quando ocorre algum desvio, a organização conta um fluxo de caixa para as despesas nos meses que não teve uma taxa de ocupação satisfatória.

A organização acompanha e avalia o desempenho das pessoas, grupos e da própria organização. De acordo com o entrevistado, é avaliado o desempenho da organização através do comparativo das metas anuais. O HOTEL F também conta com um programa hoteleiro na qual consegue verificar o quanto teve de gastos, taxas, contas, etc., sendo também considerado como uma ferramenta de controle efetivo na organização.

A organização não utiliza nenhum modelo de medição de desempenho, mas o entrevistado acredita que suas medidas de desempenho estão de acordo com as metas estratégicas porque até hoje sempre suas medidas foram eficazes. Para o entrevistado, não existe uma regra na organização, foi desenvolvida a própria maneira de se trabalhar.

Em relação aos principais indicadores de medição de desempenho adotados pela organização têm-se a taxa de ocupação, considerada como o principal indicador da organização. Também têm-se o retorno do cliente, faturamento e a satisfação do cliente.

O entrevistado disse acreditar que os indicadores utilizados são congruentes com os objetivos e metas estratégicas adotadas pela organização devido aos resultados positivos, mas que não há muita certeza se os indicadores priorizados pela organização são congruentes com os requisitos de competitividade do setor hoteleiro. Em relação aos indicadores adotados pelas grandes organizações serem viáveis nas pequenas empresas, o entrevistado disse que acredita desde que sejam feitas algumas adaptações a realidade da pequena empresa.

O entrevistado disse que não acredita que as pequenas empresas competem com as grandes organizações, pelo menos em seu setor não, pois os serviços oferecidos por cada organização é muito diferente. Também afirmou que acredita que as pequenas empresas usam princípios de administração semelhantes das grandes organizações como a gestão de qualidade. Para ele, os princípios das grandes e pequenas empresas são semelhantes, só que mais informais. O entrevistado também disse acreditar que os grandes hotéis ditam os fatores críticos de competitividade do setor hoteleiro da região, pois oferecem um produto e preço muito bons. 


\subsubsection{Estratégia: objetivos e metas estratégicas}

No HOTEL F o planejamento estratégico foi identificado como sendo informal, pois possui apenas intenções e visões estratégicas. O processo estratégico é visto como planejamento, pois apresenta características mais deliberadas, possuindo planos pré-elaborados ou bem definidos na área financeira da empresa e tendo-se uma porcentagem de investimento definida para cada setor, pois o entrevistado afirmou que até hoje "o planejamento da organização foi de crescimento". A organização não possui um plano totalmente definido, suas ações foram acontecendo. Sua orientação estratégica é buscar novos clientes, conquistando cada vez mais um maior número. Desse modo, sua estratégia é evidenciada como um processo emergente. Em relação às metas e objetivos estratégicos, nota-se que a organização tem metas, mas não formalizadas, são muito informais.

\subsubsection{Controle do Desempenho}

No HOTEL F existe a preocupação em manter o controle do desempenho, embora um controle informal. O controle ocorre na abordagem tradicional de cima para baixo, considerado como um controle participativo, na qual o gerente geral colabora com os colaboradores na busca da ação corretiva requerida. O proprietário/dirigente verifica como a organização está através do questionário de satisfação do hóspede e também através de tudo que vê, segundo ele. O HOTEL F também conta com um programa hoteleiro na qual consegue verificar o quanto teve de gastos, taxas, contas, etc. A gerência se baseia em mecanismos de controle informais, através da liderança, centralização nas decisões, delegação de autoridade baseado nas relações familiares entre os três proprietários/dirigentes. Nota-se que a organização tem uma gestão muito centralizada e com uma limitada ênfase em mecanismos de controle formais; se baseia em um controle familiar.

\subsubsection{Medição de Desempenho}

O HOTEL F prioriza a perspectiva do faturamento. As práticas de medição são muito informais. A organização baseia-se através do comparativo realizado das metas anuais, e acredita ser uma ferramenta eficiente, pois através dela consegue observar se 
está ocorrendo um crescimento ou não na organização. É acompanhado e avaliado o desempenho das pessoas, grupos e da organização como um todo se baseando sempre no ano anterior. O HOTEL F também mede seu desempenho através de um programa hoteleiro na qual consegue verificar o quanto teve de gastos, taxas, contas, etc. Outra ferramenta verificada para medir o desempenho organizacional é o contato direto dos proprietários/dirigentes com todos os departamentos e colaboradores da organização. $\mathrm{Na}$ organização não existe uma regra de medição, foi desenvolvida a própria maneira de se trabalhar.

\subsubsection{Indicadores de Medição de Desempenho}

No HOTEL F os indicadores de medição de desempenho são precedidos pela escolha da estratégia e da estrutura organizacional. Os indicadores de medição de desempenho são definidos pelos três sócio-proprietários e repassados aos chefes de departamento que os operacionaliza. Como principais indicadores de medição de desempenho adotados pela organização têm-se: a taxa de ocupação; retorno do cliente e faturamento. Para o proprietário/dirigente a fidelização do cliente com a organização é muito importante; trabalhar com pessoas é muito difícil e quando você começa a ter um retorno aí você sabe que estão gostando do seu trabalho. A organização também prioriza o faturamento mesmo porque existem meses de grande demanda e mesmo assim não tem lucro. Conclui-se que os indicadores de medição de desempenho priorizados pela organização têm o aspecto quantitativo (traduz diretamente os resultados) e retratam o aspecto qualitativo (retrata os resultados mais subjetivos que precisam de escalas comparativas para ser analisados).

\section{7 HOTEL G}

A estratégica organizacional do HOTEL G é a qualidade no atendimento do cliente. A orientação estratégica da organização em ter qualidade no atendimento é a vantagem de ser uma empresa pequena segundo a entrevistada, pois acredita conhecer todas as necessidades dos clientes, pois esta em contato com tudo. A estratégia organizacional é explicitada e declarada a todos na organização. Todos os colaboradores sabem dos objetivos e metas organizacionais e a ação dos colaboradores é orientada pela estratégia. Não só a ação do colaborador é orientada pela estratégia, mas de todos 
setores, pois a entrevistada acredita que não tem como saber para quem o hóspede vai perguntar determinada coisa; para isso todos precisam estar capacitados.

Os objetivos da organização servem como referência para produzir melhores resultados e são desdobrados em todos os níveis organizacionais. Os objetivos são transmitidos através dos treinamentos e nas reuniões que segundo a entrevistada ocorre semanalmente ou quinzenalmente com os colaboradores. A organização costuma realizar reuniões com um setor de cada vez, com os chefes de departamento que posteriormente transmitem para os demais colaboradores.

No HOTEL G, existe a preocupação com o planejamento. A entrevistada disse que a organização tem altas temporadas e são nesses períodos que costuma planejar como as coisas vão ser. Também afirmou não planejar as coisas anualmente, mas sim mensalmente, na qual faz um balanço de quanto determinado departamento vendeu, por exemplo, através de um software hoteleiro. Também afirmou contar com um planejamento diário.

Em relação a metas e objetivos, somente o setor de vendas tem metas na organização. Como principal meta do setor de vendas, a entrevistada apontou a taxa de ocupação. Segundo ela, certifica-se que as metas organizacionais estão conforme o estabelecido através do que os chefes dos departamentos a transmite e através do contato diário com tudo. Através do cumprimento das metas estabelecidas, a organização gratifica seus colaboradores: financeiramente - o departamento de vendas e os demais através das comemorações dos aniversários do mês e nas festas de final do ano.

No HOTEL G, existe a preocupação com o controle do desempenho. A organização é monitorada através de planilhas, dos questionários de satisfação respondidos pelos clientes, através das metas mensais e através do comparativo dos semestres. Como controle, a entrevistada também disse acompanhar o mercado, a economia, pois acredita que a economia tende a influenciar a taxa de ocupação. Também afirmou acreditar que as metas estratégicas são transformadas em padrões de controle na organização, pois com ele a entrevistada consegue verificar se o setor teve um bom desempenho.

A organização não utiliza nenhum modelo de medição de desempenho, mas a entrevistada afirmou que suas medidas de desempenho estão de acordo com as metas estratégicas. Segundo ela, acompanha e avalia o desempenho através dos resultados positivos da organização, mas afirma que também está atenta à concorrência. Afirma 
acompanhar muito o departamento de vendas e se preocupa com as negociações. A organização também se preocupa com as diárias médias e taxas de ocupação. Também afirmou fazer um balanço geral anual através das planilhas de resultados que o departamento de vendas a fornece para acompanhar seu desempenho.

Como principais indicadores de medição de desempenho, têm-se: a taxa de ocupação, faturamento, a satisfação dos clientes e satisfação dos colaboradores. Para a entrevistada, os indicadores de taxa de ocupação, faturamento, satisfação dos clientes e satisfação dos colaboradores estão de acordo com as metas estratégicas da organização, pois acredita que como a organização está crescendo em faturamento esteja no caminho certo; foca-se esforços na taxa de ocupação, em vendas.

A entrevistada acredita que os indicadores utilizados pela organização estão congruentes com os requisitos de competitividade do setor hoteleiro, pois acredita que todos os hotéis batalham atrás de vendas. Acredita que hoje seus indicadores estejam congruentes porque no momento esta precisando deles, mas pode ser que daqui seis meses precise mudar algum indicador.

Em relação ao ambiente impor barreiras para o alcance efetivo do controle do desempenho, a entrevistada acredita que impõe, pois afirma estar sempre em contato com a secretária de obras, com a prefeitura, secretária de turismo. Acredita que hoje em dia esteja mais preocupada com seus direitos, com seus anseios de empresária..

A entrevistada não acredita que as pequenas empresas competem com as grandes organizações, pensando no mesmo segmento turístico em que atua, porque SPA é único. Acredita não competir com hotéis de outros segmentos turísticos como hotel fazenda e lazer existentes na região. Acredita que pelo serviço oferecido possa competir com outros SPAS, mas vai da necessidade do cliente.

Em relação aos grandes hotéis da região ditar os fatores críticos de sucesso do setor hoteleiro da região, a entrevistada acredita que grandes organizações não cheguem a ditar porque seu público é diferente; seu segmento é diferenciado. Afirma que as práticas de medição de desempenho das grandes organizações não diferem das pequenas e médias empresas porque ambos estão próximos dos clientes. Para ela, as grandes organizações usam métodos semelhantes das pequenas organizações, mas de uma maneira mais formalizada como algum sistemas da internet. A entrevistada também disse que as práticas das grandes organizações podem ser viáveis nas pequenas empresas porque as pequenas organizações caminham atrás de suas práticas: têm-se serviços computadorizados e resultados cada vez melhores. 


\subsubsection{Estratégia: objetivos e metas estratégicas}

O planejamento estratégico foi identificado como sendo informal, pois possui apenas intenções e visões estratégicas, não existe nenhuma padronização com relação ao planejamento. A organização elabora planos operacionais de curto prazo e voltados para seus departamentos. No entanto, praticamente todos esses planos são desencadeados pelo setor de vendas. A criação dos planos operacionais é coletiva apenas entre os níveis gerenciais. A orientação estratégica ocorre de cima para baixo e a estratégica pode ser vista como um plano, uma vez que se segue um cronograma de ações definidas, visando ampliação, novos serviços, melhoria da estrutura física, manutenção e conquista de novos clientes, mas é predominante uma perspectiva, na medida em que, por se tratar de um SPA, possui uma forma peculiar de realizar as atividades. Em relação às metas e objetivos estratégicos, nota-se que a organização somente tem metas no setor de vendas, mas não fechadas e formalizadas. As metas e objetivos estratégicos são transmitidos aos colaboradores semanalmente durante as reuniões dos proprietários/dirigentes com os chefes de departamentos que transmitem aos demais colaboradores.

\subsubsection{Controle do Desempenho}

No HOTEL G existe a preocupação em manter o controle do desempenho, embora um controle também informal. O controle ocorre na abordagem tradicional de cima para baixo, embora seja um controle participativo, na qual os proprietários/dirigentes colaboram com os colaboradores na busca da ação corretiva requerida. Para acompanhar se as metas e objetivos estão de acordo conforme o estabelecido, a proprietária/dirigente afirma se basear nos resultados positivos da organização, mas afirma que também está atenta à concorrência. Afirma acompanhar muito o departamento de vendas e se preocupar com as negociações. A organização também avalia suas metas através das diárias médias e taxas de ocupação. O controle ocorre através das metas mensais e a proprietária/dirigente procura fazer um comparativo dos resultados das metas semestrais e anuais e também através do mercado e a economia. Nota-se que a organização tem uma gestão muito centralizada na direção e com uma limitada ênfase em mecanismos de controle formais, uma vez que somente o departamento de vendas tem metas estabelecidas. Os sócios - proprietários expressam muita confiança em que vêem embora usem planilhas comparativas. 


\subsubsection{Medição de Desempenho}

O HOTEL G prioriza a perspectiva do faturamento, pois se preocupa com a diária média e com a taxa de ocupação. As práticas de medição são muito informais e a organização não utiliza nenhum modelo de medição de desempenho. A organização mede seu desempenho através de um balanço geral anual dos resultados que o departamento de vendas fornece. Na organização existe a preocupação em reduzir as despesas; busca-se reduzir o custo e aumentar a taxa de ocupação para ter um lucro maior. O que importa na organização é o número de total de diárias vendidas no balanço realizado no final do ano. Também é acompanhado o desempenho organizacional através dos questionários de satisfação dos hóspedes, diariamente e a todo o instante.

\subsubsection{Indicadores de Medição de Desempenho}

No HOTEL G os indicadores de medição de desempenho são definidos pelos sócios/dirigentes e repassados aos chefes de departamento que os operacionaliza. Como principais indicadores de medição de desempenho adotados pela organização, têm-se: a taxa de ocupação; faturamento; a satisfação dos clientes e a satisfação dos colaboradores. Conclui-se que os indicadores de medição de desempenho priorizados pela organização têm o aspecto quantitativo (traduz diretamente os resultados), aspecto qualitativo (retrata os resultados mais subjetivos que precisam de escalas comparativas para ser analisados) e retratam o aspecto comportamental (analisa as atitudes e posturas de indivíduos e grupos).

\subsection{Síntese da Análise das Empresas}

Essa seção apresenta uma análise mais aprofundada, comparando as empresas pesquisadas com a teoria apresentada nos capítulos teóricos. Em seguida, parte-se para uma reflexão mais generalizadora, revendo as variáveis com o objetivo de obter uma explicação com maior grau de abstração, próximo ao ideal de um construto teórico.

Faz-se uso da teoria, do estudo de casos realizados, das análises comparativas entre as empresas e das situações observadas pela pesquisadora. 


\subsubsection{Processo Estratégico}

Durante o trabalho de campo, a pesquisadora evidenciou que apesar de algumas organizações estudadas já utilizarem a metodologia do Planejamento Estratégico, ainda pairam dúvidas sobre o que realmente este vem a ser e como deve ser formulado. A maior dúvida diz respeito a uma acentuada tendência para a formulação de planos, que é mal conduzida e às vezes operacional.

Nos HOTÉIS A, B e C o processo estratégico é caracterizado como planejamento, compreende o estabelecimento de objetivos e metas a serem alcançados, dos recursos necessários, e dos indicadores sobre os quais será realizada a avaliação. $\mathrm{O}$ acompanhamento dos gestores tem como finalidade assegurar que a execução corresponda ao que foi planejado, o que pressupõe a necessidade de identificar desvios que porventura ocorram na execução das atividades planejadas, estabelecendo alternativas de solução e implementação de ações para corrigir as falhas detectadas. Nos HOTÉIS D, F e G o processo estratégico é considerado como operacional, ou seja, baseado em ações mais cotidianas. No entanto, no HOTEL E o processo estratégico é visto como empreendedorismo, centrado nas ações do dirigente como inovador. $\mathrm{O}$ processo estratégico identificado nas organizações estudadas pode ser visualizado no quadro 7.1 .

\begin{tabular}{|l|c|c|c|c|c|c|c|}
\hline \multirow{2}{*}{$\begin{array}{c}\text { PROCESSO } \\
\text { ESTRATÉGICO }\end{array}$} & \multicolumn{9}{|c|}{ HOTÉIS } \\
\cline { 2 - 9 } & $\mathrm{A}$ & $\mathrm{B}$ & $\mathrm{C}$ & $\mathrm{D}$ & $\mathrm{E}$ & $\mathrm{F}$ & $\mathrm{G}$ \\
\hline PLANEJAMENTO & $\mathrm{X}$ & $\mathrm{X}$ & $\mathrm{X}$ & & & & \\
\hline EMPREENDEDORISMO & & & & & $\mathrm{X}$ & & \\
\hline EMERGENTE & & & & $\mathrm{X}$ & & $\mathrm{X}$ & $\mathrm{X}$ \\
\hline
\end{tabular}

Quadro 7.1: Definição do processo estratégico por hotel

$\mathrm{Na}$ seqüência, foi perguntado sobre a estratégia organizacional, se a organização tem uma estratégia. Nos HOTÉIS A, C, D, E, F e G a estratégia é vista como um plano, pois as estratégias pretendidas servem como um guia ou curso de ação para o futuro da organização. No entanto, no HOTEL B, a estratégia caracteriza-se como posição, pela busca do reconhecimento da organização em ser referência, pois se pretende firmar seu reconhecimento como meio de hospedagem e de sua marca no mercado. O quadro abaixo (7.2) caracteriza o tipo de definição de estratégia nos meios de hospedagem estudados. 


\begin{tabular}{|l|c|c|c|c|c|c|c|}
\hline \multicolumn{1}{|c|}{ ESTRATÉGIA } & \multicolumn{6}{|c|}{ HOTÉIS } \\
\cline { 2 - 8 } & A & B & C & D & E & F & G \\
\hline PLANO & $\mathrm{x}$ & & $\mathrm{x}$ & $\mathrm{x}$ & $\mathrm{x}$ & $\mathrm{x}$ & $\mathrm{x}$ \\
\hline POSIÇÃO & & $\mathrm{x}$ & & & & & \\
\hline
\end{tabular}

Quadro 7.2: Tipos de estratégia organizacional

Por sua vez, o nível de caracterização do planejamento, como operacional e/ou estratégico, bem como seu grau de formalização foram identificados durante a pesquisa e podem ser vistos no quadro 7.3. Nos HOTÉIS A e B, o planejamento é formalizado, devido à existência de um processo completo de planejamento. No HOTEL A existe um plano para cada setor com etapas bem definidas e é englobado tanto o planejamento estratégico quanto o operacional. Já no HOTEL B, as ações de curto e médio prazo são estabelecidas, embora também seja englobado tanto o planejamento estratégico quanto o operacional. Ambos os hotéis, estão associados a um processo sistemático, que envolve pessoas e a coleta e analise de dados. Já no restante dos hotéis, C, D, E, F e G o planejamento é parcialmente formalizado, contendo apenas um plano e alguns objetivos escritos.

\begin{tabular}{|l|c|c|c|c|c|c|c|}
\hline \multirow{2}{*}{$\begin{array}{c}\text { FORMALIZAÇÃO } \\
\text { PLANEJAMENTO }\end{array}$} & \multicolumn{9}{|c|}{ HOTÉIS } \\
\cline { 2 - 8 } & $\mathrm{A}$ & $\mathrm{B}$ & $\mathrm{C}$ & $\mathrm{D}$ & $\mathrm{E}$ & $\mathrm{F}$ & $\mathrm{G}$ \\
\hline FORMALIZADO & $\mathrm{X}$ & $\mathrm{X}$ & & & & & \\
\hline INFORMAL & & & $\mathrm{X}$ & $\mathrm{X}$ & $\mathrm{X}$ & $\mathrm{X}$ & $\mathrm{X}$ \\
\hline
\end{tabular}

Quadro 7.3: Nível e grau de formalização do planejamento

Com a pesquisa, verificou-se que a maioria das empresas não realiza o planejamento formal, $80 \%$, e das que o realizam, $20 \%$ utilizam o planejamento de longo e de curto prazo, o que mostra a preocupação dos empresários com a utilização de mecanismos de apóio no gerenciamento do negócio e a existência de uma hierarquia no uso do planejamento formal. Das empresas que não realizam o planejamento formal, realizam algum tipo de planejamento dentro da empresa. 


\subsubsection{Controle do Desempenho}

Na seqüência, também foi perguntado se a organização faz o controle do desempenho organizacional. Em todos os hotéis pesquisados, existe a preocupação com o controle do desempenho.

Em relação ao tipo de controle aplicado na organização, o HOTEL A caracteriza-se como um controle por resultados, pois a organização faz uso de outros critérios de gestão e não, simplesmente contábeis. No HOTEL B o controle é formalizado, pois há uma elevada centralização e formalização de procedimentos. Nos HOTÉIS C, E e G o controle é centralizado na direção e seletivamente formal, pois nota-se uma gestão descentralizada e com uma limitada ênfase em mecanismos de controle formais, mas que promovem o autocontrole. Nos HOTÉIS D e F tem-se uma gestão muito centralizada na direção e com uma limitada ênfase em mecanismos de controle formais; tem um controle baseado nas relações familiares.

\begin{tabular}{|c|c|c|c|c|c|c|c|}
\hline \multirow{2}{*}{$\begin{array}{c}\text { CONTROLE } \\
\text { DO DESEMPENHO }\end{array}$} & \multicolumn{7}{|c|}{ HOTÉIS } \\
\hline & A & B & C & D & E & $\mathrm{F}$ & G \\
\hline RESULTADOS & $\mathrm{x}$ & & & & & & \\
\hline $\begin{array}{l}\text { CENTRALIZADO NA } \\
\text { DIREÇÃO, SELETIVAMENTE } \\
\text { FORMAL }\end{array}$ & & & $x$ & & $\mathrm{x}$ & & $x$ \\
\hline FORMALIZADO & & $\mathrm{x}$ & & & & & \\
\hline FAMILIAR E INFORMAL & & & & $\mathrm{x}$ & & $\mathrm{x}$ & \\
\hline
\end{tabular}

Quadro 7.4: Tipos de controle do desempenho

Quanto ao sistema do controle, os dados demonstraram que $100 \%$ dos hotéis têm metas e objetivos organizacionais e que as metas estratégicas são transformadas em padrões de controle. O quadro 7.5 apresenta como as organizações fazem para se certificar que a meta organizacional está sendo alcançada conforme o estabelecido. 


\begin{tabular}{|c|c|c|c|c|c|c|c|}
\hline \multirow{2}{*}{ FORMAS DE CONTROLE } & \multicolumn{7}{|c|}{ HOTEL } \\
\hline & A & B & C & D & E & F & G \\
\hline SATISFAÇÃO & $\mathrm{x}$ & & $\mathrm{x}$ & $\mathrm{x}$ & $\mathrm{x}$ & $\mathrm{x}$ & $\mathrm{x}$ \\
\hline OBSERVAÇÃO & $\mathrm{x}$ & & $\mathrm{x}$ & $\mathrm{x}$ & $\mathrm{x}$ & $\mathrm{x}$ & $\mathrm{x}$ \\
\hline PLANILHAS & & $\mathrm{x}$ & $\mathrm{x}$ & & & & $\mathrm{x}$ \\
\hline REUNIÕES & $\mathrm{x}$ & $\mathrm{x}$ & & & & & \\
\hline SISTEMA OPERACIONAL & & & $\mathrm{x}$ & & $\mathrm{x}$ & & \\
\hline FATURAMENTO & & & & $\mathrm{x}$ & & & \\
\hline DESPESAS & & & & $\mathrm{x}$ & & & $\mathrm{x}$ \\
\hline COLABORADORES & & & & & & & $\mathrm{x}$ \\
\hline TAXA DE OCUPAÇÃO & & & & $\mathrm{x}$ & & & $\mathrm{x}$ \\
\hline MERCADO EXTERNO & & & & & & & $\mathrm{x}$ \\
\hline
\end{tabular}

Quadro 7.5: Formas de controle do desempenho

Mesmo com mecanismos de controle do desempenho diferenciados, todas as organizações pesquisadas o realizam de uma maneira mais formal ou informal. Evidenciou-se que os mecanismos de controle são adequados as características do contexto social de cada organização e, como consequiência, está relacionada à estratégia da empresa. O mecanismo de controle está relacionado com o processo estratégico, com os objetivos e metas, contribuindo tanto na formulação de alternativas estratégicas. Assim, os mecanismos de controle são desenhados segundo as características da estratégia traçada para a organização. Deve-se atentar que manter o controle do desempenho é formular e avaliar a validade a priori de uma estratégia, bem como a adequação de sua implantação.

Em relação ao desempenho organizacional, todos os hotéis contam com um sistema próprio de medição de desempenho, de acordo com as características do empreendimento. Conclusões como essas apontam a inexistência de um modelo formalizado de medição de desempenho em grandes organizações e semelhantes as pequenas e médias empresas. A pesquisadora evidenciou que todas as organizações pesquisadas conhecem a importância da medição de desempenho para a gestão hoteleira, na qual todos afirmaram avaliar seu desempenho.

Dos hotéis que medem o desempenho, os HOTÉIS C, F e G declaram utilizar planilhas comparativas, os HOTÉIS A, C, D, F e G informaram medir o desempenho por meio de observações, os HOTÉIS B, C, E, F e G afirmaram utilizar questionários de satisfação respondidos pelos clientes, os HOTÉIS A, C, E, F e G através de um sistema 
hoteleiro, os HOTÉIS C e G realizam pesquisas de mercado e os HOTÉIS E e G através da taxa de ocupação e diária média. Conclui-se, desta forma, que os hotéis pesquisados não utilizam modelos formais de medição de desempenho e priorizam a perspectiva dos clientes, conforme o quadro 7.6 abaixo.

\begin{tabular}{|c|c|c|c|c|c|c|c|}
\hline \multirow{2}{*}{ FORMAS DE MEDIÇÃO } & \multicolumn{5}{|c|}{ HOTEL } \\
\hline & A & B & C & D & E & F & G \\
\hline AVALIAÇÃO DE DESEMPENHO (AADD) & $\mathrm{x}$ & & & & & & \\
\hline AUDITORIAS & $\mathrm{x}$ & & & & & & \\
\hline INSPEÇÕES & $\mathrm{x}$ & & & & & & \\
\hline SATISFAÇÃO DOS COLABORADORES & $\mathrm{x}$ & & & & & & \\
\hline QUESTIONÁRIO DE SATISFAÇÃO DOS HÓSPEDES & & $\mathrm{x}$ & $\mathrm{x}$ & & $\mathrm{x}$ & $\mathrm{x}$ & $\mathrm{x}$ \\
\hline PLANILHA COMPARATIVA & & & $\mathrm{x}$ & & & $\mathrm{x}$ & $\mathrm{x}$ \\
\hline OBSERVAÇÃO & & & $\mathrm{x}$ & $\mathrm{x}$ & & $\mathrm{x}$ & $\mathrm{x}$ \\
\hline SISTEMA HOTELEIRO & & & $\mathrm{x}$ & & $\mathrm{x}$ & $\mathrm{x}$ & $\mathrm{x}$ \\
\hline PESQUISA DE MERCADO & & & $\mathrm{x}$ & & $\mathrm{x}$ & $\mathrm{x}$ \\
\hline TAXA MÉDIA DE OCUPAÇÃO & & & & & & & $\mathrm{x}$ \\
\hline Q
\end{tabular}

Quadro 7.6: Matriz hotel x formas de medição

Em relação às práticas de medição de desempenho das grandes organizações diferirem das pequenas e médias empresas, todos os hotéis afirmaram que não acreditam que as práticas de medição de desempenho das grandes organizações diferem das pequenas e médias. A grande maioria, diz acreditar que as grandes organizações usam métodos mais formalizados e que de alguma maneira os pequenos e médios hotéis tentam utilizá-los, seguir métodos semelhantes das grandes organizações.

\subsubsection{Indicadores de Medição de Desempenho}

Foi identificado durante a pesquisa que os indicadores de medição de desempenho são utilizados para avaliação de processos de trabalho, de equipes e dos colaboradores. Quanto aos indicadores de medição de desempenho utilizados: $43 \%$ dos hotéis (A, B, C, D, E, F e G) afirmaram priorizar a taxa média de ocupação e diária média; $29 \%$ dos hotéis (A, B, D e G) priorizam a satisfação dos clientes e $29 \%$ dos hotéis (A, D, E e G) priorizam a satisfação dos colaboradores, ou seja, os indicadores mais utilizados pelos hotéis estudados enquadram-se na perspectiva dos clientes. 


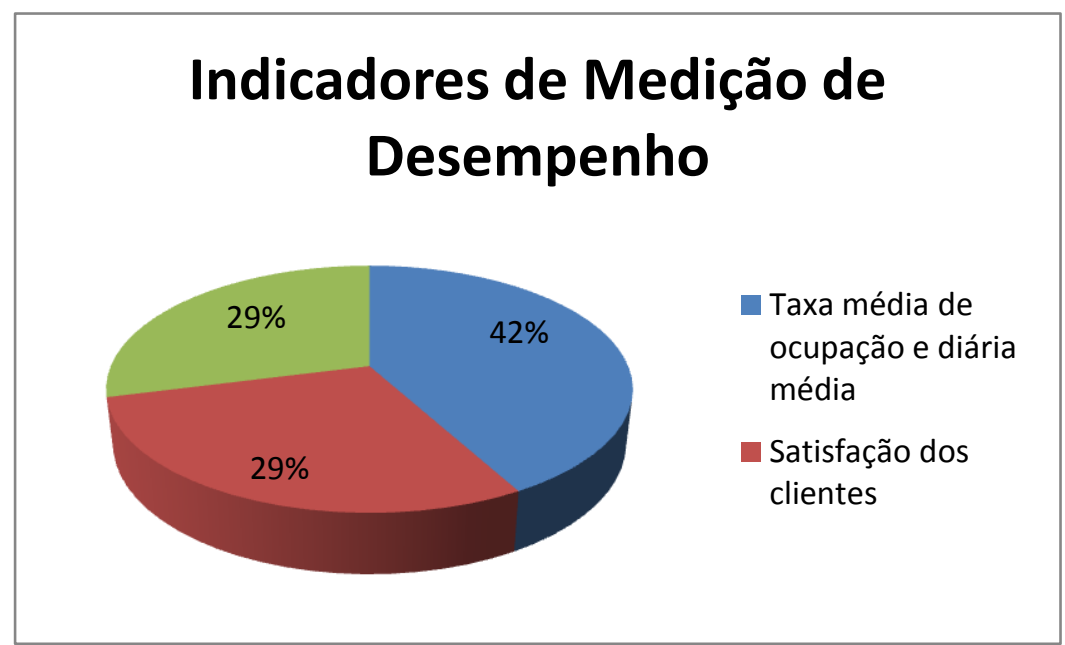

Gráfico 7.1: Indicadores de desempenho utilizados pelos hotéis pesquisados

Considerando os indicadores citados, percebe-se que todos os hotéis pesquisados responderam a este quesito: utilizam algum indicador financeiro e não financeiro para medir o desempenho. Quanto aos indicadores, o quadro 7.7 os divide em:

\begin{tabular}{|c|l|}
\hline \multicolumn{1}{|c|}{ TEMA } & \multicolumn{1}{c|}{ INDICADORES UTILIZADOS } \\
\hline CLIENTES & - Satisfação dos clientes \\
\hline COLABORADORES & - Treinamento \\
& - GPTW (good place to work) \\
& - Satisfação dos colaboradores \\
& - Turnover (rotatividade) \\
& - PMP (Plano de manutenção preventiva) \\
\hline FINANCEIRO & -Taxa de ocupação \\
& -Diária média \\
& -Resavision \\
& -GAP e autocontrole \\
& -Vendas \\
& -Despesas \\
& -Receita por apartamento disponível (REVPAR) \\
& -Prejuízo \\
& -Lucratividade \\
& -Pagamentos \\
\hline
\end{tabular}

Quadro 7.7: Matriz de indicadores hoteleiros

Deste modo, atentando-se ao uso de indicadores, conclui-se que as maiorias dos hotéis pesquisados priorizam os indicadores financeiros, uma vez que todos utilizam pelos menos uma medida financeira para a medição de desempenho, conforme aponta os resultados de Araújo (2001) e FOHB (2006). De todos os indicadores levantados, os 
mais citados foram a taxa média de ocupação e diária média, satisfação dos clientes e satisfação dos colaboradores respectivamente.

Quanto aos indicadores de medição de desempenho ser congruentes com os fatores críticos do setor hoteleiro da região, todos os dirigentes dos hotéis entrevistados acreditam que seus indicadores de desempenho são congruentes. Observa-se que os dirigentes direcionam seus indicadores para a competitividade do setor, ainda que os grandes hotéis apresentem um maior número de indicadores e os pequenos hotéis um menor número.

\subsubsection{Especificidades das Pequenas e Médias Empresas}

Todos os dirigentes, o que pode ser justificado pelas características peculiares da pequena empresa e, dessa forma, pelo forte envolvimento que têm com o negócio, enquadram-se com características operadoras ou empreendedoras. Dessa forma, pode-se afirmar que os dirigentes participantes da pesquisa caracterizam-se essencialmente como empreendedor o HOTEL E e como operador os HOTÉIS D, F e G. As principais características organizacionais dos hotéis podem ser consultadas no quadro 7.8.

\begin{tabular}{|c|c|c|c|c|}
\hline HOTÉIS & D & E & F & G \\
\hline EMPREENDEDORES & & $\mathrm{x}$ & & \\
\hline OPERADORES & $\mathrm{x}$ & & $\mathrm{x}$ & $\mathrm{x}$ \\
\hline
\end{tabular}

Quadro 7.8: Descrição de características dos dirigentes das empresas estudadas

Durante a pesquisa, ficou evidenciado que nos hotéis de pequeno porte (HOTÉIS D, E, F e G), a figura central é o proprietário/dirigente e talvez o único a influenciar o comportamento estratégico organizacional, pois é ele quem direciona os rumos do negócio. As principais características organizacionais dos hotéis podem ser consultadas no quadro 7.9 .

\begin{tabular}{|c|c|c|c|c|c|c|c|c|c|}
\hline \multicolumn{3}{|c|}{ ORGANIZAÇÃO } & \multicolumn{7}{|c|}{ HOTÉIS } \\
\hline & & & A & B & C & D & $E$ & $\mathrm{~F}$ & G \\
\hline \multirow[t]{2}{*}{ ESTRUTURA } & HORIZONTAL & & $x$ & & & $x$ & $x$ & $x$ & $x$ \\
\hline & VERTICAL & & & $\mathrm{x}$ & $\mathrm{x}$ & & & & \\
\hline \multicolumn{3}{|c|}{ CENTRALIZAÇÃO DE CARGOS E FUNÇÕES } & & $\mathrm{x}$ & $x$ & & & & \\
\hline \multirow{2}{*}{\multicolumn{2}{|c|}{$\begin{array}{l}\text { FORMALIZAÇÃO (CARGOS } \\
\text { E FUNÇÕES) }\end{array}$}} & FLEXÍVEIS & & & & $x$ & $\mathrm{x}$ & $\mathrm{x}$ & $x$ \\
\hline & & $\begin{array}{l}\text { PARCIALMENTE } \\
\text { FORMALIZADO }\end{array}$ & $x$ & $x$ & $x$ & & & & \\
\hline \multicolumn{3}{|c|}{ EMPRESA FAMILIAR } & & & $x$ & $\mathrm{x}$ & $\mathrm{x}$ & $\mathrm{x}$ & $\mathrm{x}$ \\
\hline
\end{tabular}

Quadro 7.9: Descrição de características organizacionais das empresas pesquisadas 
As empresas pesquisadas (HOTÉIS C, D, E, F e G) são consideradas familiares, o HOTEL A foca-se numa estrutura mais horizontal e os HOTÉIS B e C são mais verticais e com centralização de cargos e funções. Não foi identificada a total formalização de cargos e funções, eles são parcialmente formalizados nos HOTÉIS C, E e F e flexíveis nos HOTÉIS A, B e D.

Em relação aos grandes hotéis da região ditar os fatores-críticos de sucesso do setor hoteleiro da região, apenas os HOTÉIS A, B e F disseram acreditar, pois acham que esses hotéis têm, por exemplo, melhores condições de infra-estrutura, pessoal qualificado e melhores condições financeiras, enquanto os HOTÉIS C, D, E e F disseram que não acreditam, pois para a maioria desses hotéis a região apresenta uma hotelaria muito caseira. Contudo, apenas o HOTEL B argumentou que como tenta ser uma referência, os pequenos e médios hotéis tentam se espelhar nele.

Por sua vez, ao inferir que as pequenas empresas competem com as grandes organizações, os HOTÉIS C, D, F, E afirmaram que organizações menores competem, pois também oferece um serviço de qualidade, bom atendimento e usam indicadores semelhantes das grandes organizações. No entanto, os HOTÉIS A, B, G disseram que não competem, pois para eles ser maior possibilita maiores condições de investimento, podendo atender o padrão de serviços que o mercado e o cliente exigem.

Ao inferir que o ambiente impõe barreiras para o alcance efetivo do controle do desempenho nas pequenas empresas, os HOTÉIS D, E e F não acreditam que o ambiente impõe alguma barreira para o alcance efetivo do controle na organização. Somente o HOTEL G disse acreditar que o ambiente impõe barreiras como alguma mudança e necessidade do mercado.

Quanto às pequenas empresas usarem princípios administrativos e também de controle e desempenho organizacional semelhantes das grandes organizações, todos os hotéis acreditam que sim, pois os princípios de ambas as empresas são semelhantes, as práticas é que são mais informais. Para todos os hotéis, as grandes empresas diferenciam-se, pois tendem a utilizar, por exemplo, sistemas e planilhas informatizadas.

Como principais características referentes ao setor hoteleiro que influenciam a gestão dos hotéis pesquisados estão apresentadas no quadro 7.10. 


\begin{tabular}{|l|c|c|c|c|c|c|c|}
\hline \multicolumn{1}{|c|}{ CARACTERÍSTICAS } & \multicolumn{7}{|c|}{ HOTÉlS } \\
\cline { 2 - 8 } & A & B & C & D & E & F & G \\
\hline Mercado & x & x & & & x & x & x \\
\hline Heterogeneidade da Demanda & & $\mathrm{x}$ & $\mathrm{x}$ & $\mathrm{x}$ & $\mathrm{x}$ & $\mathrm{x}$ & $\mathrm{x}$ \\
\hline Sazonalidade & & & $\mathrm{x}$ & & $\mathrm{x}$ & $\mathrm{x}$ & $\mathrm{x}$ \\
\hline Intangibilidade & $\mathrm{x}$ & $\mathrm{x}$ & $\mathrm{x}$ & $\mathrm{x}$ & $\mathrm{x}$ & $\mathrm{x}$ & $\mathrm{x}$ \\
\hline
\end{tabular}

Quadro 7.10: Especificidades do setor hoteleiro que influenciam a gestão das empresas estudadas

Em relação às especificidades do setor hoteleiro, pode-se observar em todos os hotéis, o contato direto dos clientes com a produção e consumo dos serviços oferecidos. Este aspecto também está ligado à intangibilidade dos serviços, que faz com que a qualidade seja subjetiva. A preocupação com a intangibilidade é observada em todos os hotéis.

\subsubsection{Síntese da Análise por Segmento Hoteleiro}

Nessa pesquisa, não foi possível constatar que a diferença entre os segmentos turísticos influenciassem no controle do desempenho. Novas pesquisas são necessárias, para confirmar que não existe essa diferenciação.

A pesquisadora identificou que apesar das organizações apresentarem diferentes segmentos turísticos, os indicadores de controle do desempenho adotados são semelhantes. A diferença entre essas organizações não é o segmento turístico, mas sim o porte. Na grande empresa, o modelo de medição é mais formalizado, contam com um maior numero de indicadores. Já a pequena empresa focaliza em poucos critérios de desempenho, por isso não consegue chegar aos modelos das grandes por trabalharem com poucos indicadores.

Em relação ao porte, foi identificado semelhanças no modo de agir das organizações; a grande empresa usa mais critérios formalizados, enquanto a pequena empresa usa critérios mais informais. Além da diferença de porte e segmento turístico, há a diferença de profissionalismo, tanto dos proprietários/dirigentes como dos gerentes. Essa profissionalização não pode ocorrer somente através da contratação de gerentes, mas também pela postura, treinamento e estilos dos proprietários, como ocorre no HOTEL G. Desse modo, conclui-se que as pequenas empresas caminham para algo semelhante na grande organização. 
A tendência é das grandes empresas terem uma grande variedade de indicadores sobre um tema, como apresenta o quadro 8.7. A pequena empresa é seletiva em relação aos indicadores adotados, priorizam um menor número. 


\section{CONSIDERAÇÕES FINAIS}

Este capítulo tem como propósito evidenciar os principais resultados alcançados com os dados empíricos, tendo por base os conceitos abordados na revisão teórica, e apresentar a descrição prática sobre a medição de desempenho organizacional das pequenas e médias empresas com o qual almeja contribuir para a melhoria do potencial de gestão das empresas.

Este trabalho faz parte dos estudos desenvolvidos pelo GEOPE-EESC-USP que tem por objetivo investigar os temas organizacionais na pequena empresa a fim de se buscar uma melhor adequação das ferramentas gerenciais. Espera-se que o trabalho contribua não só para o grupo de pesquisa, mas também para a Teoria Administrativa da Pequena Empresa e para o relacionamento das áreas de Engenharia de Produção, Turismo, Hotelaria e Gestão Estratégica.

As variáveis de pesquisas que orientaram o trabalho de campo foram: Especificidades das Pequenas e Médias Empresas, Empresa Hoteleira e Medição de Desempenho Organizacional.

Este trabalho procurou avaliar a existência de uma orientação do controle do desempenho utilizados nas pequenas e médias empresas hoteleiras e sua adequação aos fatores-chave de competitividade do setor. Para alcançar esse objetivo, a pesquisadora identificou que as pequenas e médias empresas hoteleiras da região central do Estado de São Paulo realizam controle do desempenho; estabelecem indicadores e estes estão orientados para os fatores-chave do setor. Em alguns casos estudados na pesquisa, é possível afirmar o uso do controle do desempenho de maneira híbrida, vindo de diferentes métodos e que, foram adaptados à realidade de cada organização.

Confirma-se a importância da estratégia nas organizações aos vários níveis hierárquicos, conforme confirmam Kaplan e Norton. Nos hotéis A, B, C, F e G fica evidente o desdobramento da estratégia do nível estratégico ao nível operacional, pois comunica e alinha a estratégia a toda a organização. 
Também foi evidenciada a diferença de gestão do desempenho entre pequenas e grandes empresas. Nas grandes empresas, a gestão do desempenho dá suporte à análise crítica dos resultados da organização, às tomadas de decisão e ao replanejamento. Essas empresas contam com planilhas comparativas, tabelas, sistemas informatizados e documentos escritos. Já nas pequenas empresas, a gestão do desempenho ocorre mais informalmente, contam com planilhas e tabelas comparativas mais simples, mas suas práticas gerenciais não oferecem uma análise crítica dos resultados organizacionais, às tomadas de decisão e ao replanejamento como nas grandes empresas.

Pode-se verificar a falta de modelos de medição de desempenho pelas pequenas e médias empresas hoteleiras. Os resultados da pesquisa vêm mostrar que há ainda um longo caminho a ser seguido para elas utilizarem efetivamente modelos de medição de desempenho. Contudo, os resultados obtidos até o momento, permitem afirmar que as medições são fundamentais para impulsionar o processo de melhoria organizacional. $\mathrm{O}$ conhecimento por parte dos dirigentes-proprietários das especificidades das pequenas empresas hoteleiras pode minimizar dificuldades enfrentadas por elas. Em se tratando dos atores participantes do processo de medição de desempenho organizacional, os clientes são os mais citados. A perspectiva dos clientes é a preocupação principal das organizações, a satisfação das suas expectativas através do atendimento às suas necessidades. Nesse sentido, as pequenas organizações utilizam seus colaboradores como uma grande fonte de informação para a melhoria dos serviços e produtos prestados.

Com base nas opiniões das empresas quanto à importância dos indicadores de desempenho, independentemente de ter um modelo de medição de desempenho formalizado ou priorizar determinados indicadores, todas as organizações pesquisadas tem a participação efetiva dos dirigentes. Já com base na análise dos resultados dos questionários aplicados e através da observação de acordo com o referencial teórico, verificou-se que os hotéis pesquisados possuem um sistema de medição de desempenho informal e não-estruturado. A preocupação principal das organizações é com a satisfação das expectativas dos clientes através do atendimento às suas necessidades. $\mathrm{E}$ não se pode esquecer, independentemente do porte da organização, de que os clientes, cada vez mais exigentes, esperam cada vez mais qualidade. Contraditoriamente, a inadequação de práticas gerenciais e a não satisfação de suas necessidades, compromete 
substancialmente o alcance dos objetivos e metas organizacionais e, mesmo, a sobrevivência do empreendimento.

Alguns resultados já comentados no item 7.8 "Síntese da Análise das Empresas" merecem destaque. De acordo com as respostas obtidas, percebe-se que nas organizações há uma predominância nos indicadores de desempenho relacionados à satisfação dos clientes. Todos os hotéis afirmaram a importância de atender as necessidades e expectativas de seus clientes. Contudo, o foco financeiro também foi evidenciado, ou seja, mesmo com a priorização da satisfação dos clientes, os resultados apontam alguns indicadores econômicos como faturamento; tradicionalmente continuam sendo privilegiados.

Os indicadores de desempenho tanto das grandes como das pequenas empresas foram identificados como semelhantes, independentemente do segmento turístico e porte. A diferença está na formalização desses indicadores, ou seja, as grandes empresas contam com um maior número de indicadores que são cuidadosamente especificados. Os indicadores são escritos e transmitidos a todos os colaboradores e precisam ser intimamente cumpridos, embora as pequenas empresas já caminhem nesse sentido. $\mathrm{O}$ indicador na grande empresa é gerado criteriosamente, a fim de segurar a disponibilidade dos dados e resultados mais relevantes à organização em menor tempo possível e ao menor custo. Em ambas as empresas, os indicadores estão centrados nos clientes, ligados ao conceito de qualidade na organização. Uma vez que os clientes explicitam suas necessidades, ambas as empresas traduzem-nas através de características de qualidade aos clientes.

Com base nos resultados dos indicadores de desempenho, as grandes empresas de fato estabelecem os critérios do setor hoteleiro da região, pois as pequenas empresas tentam se espelhar em suas práticas organizacionais. Assim, conclui-se que, os indicadores das pequenas e grandes empresas possibilitam o desdobramento das metas organizacionais, assegurando que as melhorias obtidas em cada departamento contribuirão para os propósitos da organização.

Outro ponto evidenciado na pesquisa foi a satisfação dos colaboradores, muito destacada nas entrevistas. A satisfação dos colaboradores foi relacionada com a busca da satisfação dos clientes, pois todos os entrevistados acreditam que ambos caminham juntos. Se o colaborar está satisfeito, o cliente também ficará, pois o colaborador vai trabalhar motivado, na busca do alcance dos objetivos da organização, atendendo com presteza e fazendo seu serviço com qualidade. 
O fato das organizações pesquisadas serem na grande maioria familiares, a separação entre os gastos próprios e empresariais é uma recomendação imprescindível. É necessário atentar-se para o fato de que alguns indicadores de medição de desempenho são diferenciais da grande empresa, embora sejam viáveis de uma maneira mais informal nas pequenas empresas.

Reunindo informações coletadas do roteiro de entrevistas, observações livres, referencial teórico e as informações e experiências vivenciadas com os estudos de casos, observou-se que todas as empresas estudadas reconhecem a importância da medição de desempenho organizacional, mas a gerenciam de forma diferenciada, seja por estar relacionada a um tipo de meio de hospedagem diversificado, pelo tamanho da própria empresa ou pela forma que o proprietário-dirigente a considera.

Como os serviços são intangíveis, e empresas prestadoras de serviços estão em contato direto com o cliente, o setor hoteleiro apresenta características peculiares, devido ao produto turístico, exigindo uma administração diferenciada, bem como sua gestão. A hotelaria precisa ser vista com seriedade e como sistema complexo a ser construído com visão estratégica e sustentável.

Antes de tudo, nas empresas hoteleiras é preciso reconhecer que os seres humanos têm, além das necessidades econômicas, aspirações psicológicas, sociais, precisam ser motivadas, reconhecidas e valorizadas para sentirem-se parte de um "time" Dessa maneira, ganhos de realização pessoal dos colaboradores, gratificações e retornos de produtividade e qualidade organizacional poderão ser observados.

A divulgação das cidades e sua melhoria em que os tipos de meios de hospedagem encontram-se são preponderantes, pois inicialmente os turistas selecionam para onde pretendem ir e depois, opta pelo meio de hospedagem de acordo com suas preferências, gostos, necessidades, localização e serviços oferecidos. Por isso, os municípios precisam se organizar e lutar pelo desenvolvimento do potencial turístico, utilizando-se para tanto de parcerias com secretarias de Turismo, associações como o Comtur (Conselho Municipal de Turismo), Bureaus, entre outros.

O conhecimento das especificidades e portes dos meios de hospedagem foi válido a pesquisadora, mesmo que as grandes empresas não foram da pesquisa, as visitas, conversas informais com dirigentes funcionários e observações contribuíram para o conhecimento da realidade do setor.

Foi evidenciado que nem sempre a denominação turística é condizente com os serviços oferecidos aos clientes nas empresas hoteleiras. Muitos optam pela mistura 
como Hotel-Pousada, uma vez que acreditam que essa mistura amplie a abrangência em relação ao público. Uma recomendação a essas empresas é a adequação do nome com as características específicas turísticas.

A pesquisa pode ser considerada inovadora, pois há poucas referências bibliográficas na literatura brasileira sobre as diversas áreas abordadas na pesquisa: Estratégia, Controle do Desempenho, Medição de Desempenho, Indicadores de Medição de Desempenho, Pequena Empresa, Turismo e Hotelaria Estudos futuros podem focar possíveis lacunas no presente trabalho, como alternativas para desenvolvimento do turismo e outras formas de segmentação, como, os benefícios de projetos de desenvolvimento para a Regionalização do Turismo - iniciativa também coordenada pelo SEBRAE, para o desenvolvimento e divulgação dos Circuitos Paulistas e para a qual as universidades também poderiam contribuir com informações científicas em pesquisas para desenvolvimento e consolidação de projetos voltados aos circuitos turísticos, como da Chapada Guarani e Ecocaipira.

As sugestões para estudos futuros são:

- Incluir mais respondentes, diferentes participantes do sistema de medição de desempenho em diferentes níveis organizacionais, da maneira que cada um teria uma visão diferenciada do processo de medição de desempenho;

- A partir de um modelo proposto, desenvolver mais detalhadamente os indicadores de medição de desempenho das empresas hoteleiras e testar sua aderência e validade em diversas organizações;

- Medir a real eficácia dos indicadores de medição de desempenho adotados pelas empresas hoteleiras;

- Incluir mais circuitos turísticos do Estado de São Paulo, tendo um estudo comparativo.

\section{1 Limitações do Estudo}

Como limitações a esse estudo, alguns pontos devem ser destacados:

- A principal limitação do estudo foi o pequeno número de empresas pesquisadas, seguida pelo fato de ter a amostra sido escolhida por conveniência, e não aleatoriamente.

- A complexidade ao tema de estudo, apesar da intensidade de pesquisas e variedade de opções de métodos e aplicações disponíveis. 
- A pesquisadora encontrou limitações em relação à "fala de alguém", quando conversado com mais pessoas além dos entrevistados.

- Deve-se observar que os indicadores de medição de desempenho, pela maior parte de hotéis, são mensurados através de conversas informais, o que pode inibir os respondentes.

- A falta de uma visão sistêmica e holística de alguns administradores por conhecerem o que realmente acontece na sua organização.

- Inerente dificuldade de alguns administradores definirem adequadamente seus indicadores e suas metas, pois os processos envolvidos estão sujeitos a variáveis que muitas vezes podem ser incontroláveis.

- A coleta de dados foi realizada, em todos os casos, na presença da pesquisadora, possibilitando a explicação das questões, maior conhecimento do ambiente organizacional, além da obtenção de informações por meio de conversas informais entre a pesquisadora e os respondentes. Porém, em alguns casos, observa-se certo constrangimento e desentendimento por parte dos respondentes na afirmação de determinadas questões, podendo assim, terem sido coletadas informações distorcidas ou incertas.

- Ainda, o estudo de caso não permite generalizações, uma vez que a pesquisa é centrada em um setor específico (serviços hoteleiro), o porte (pequena empresa) e a região escolhida (Região Central do Estado de São Paulo).

É importante destacar que os dirigentes que participaram da pesquisa foram receptivos com a pesquisa e demonstraram interesse em colaborar com ela e também em receber os resultados da pesquisa, contribuindo para a gestão de seu empreendimento. 


\section{REFERÊNCIAS BIBLIOGRÁFICAS}

AIDAR, M. M. (2003). Racionalidade limitada: a difusão do modelo balanced scorecard nas organizações. FGV-EAESP. p. 01-28, Dez..

ALBUQUERQUE, A. F. (2004). Gestão estratégica das informações internas na pequena empresa: estudo comparativo de casos em empresas do setor de serviços (hoteleiro) da região de Brotas-SP. Dissertação (Mestrado) EESC-USP, p.209.

ALMEIDA, M.I.R. (1994). Desenvolvimento de um método de planejamento estratégico para grupos de pequenas empresas. 1994. 118p. Tese (Doutorado) - Faculdade de Economia Administração e Contabilidade, Universidade de São Paulo, São Paulo.

ÁLVARO, J.A.H. (2001). Sistema de indicadores para la mejora y el control integrado de la calidad de los procesos. Castelló de la Plana: Publicacions de la Universitat Jauma.

A MAIOR indústria do mundo.(2007) Anuário do Turismo (2007-2008). Disponível em: <http://portalexame.abril.com.br/static/aberto/turismo/anuario_exame_turismo/m0125844.html $>$. Acesso em: 10 set.

AMATO NETO, J. (2000). Redes de cooperação produtiva e clusters regionais: oportunidades para as pequenas e médias empresas. São Paulo: Atlas; Fundação Vanzolini.

ANÁLISE setorial: a indústria hoteleira. (1999). Gazeta Mercantil, Panorama setorial, São Paulo, v.1, n.3.

ANDERSEN, A. (1999). Remuneração estratégica: uma vantagem competitiva. São Paulo: Atlas.

ANDRADE, J. H. (2004). Gestão da informação do ambiente externo na pequena empresa: esboço de uma rede de cooperação hoteleira na região de Brotas-SP a partir da identificação de parceiros e potenciais atividades de negócio a serem compartilhadas. São Carlos: EESC/USP (Relatório Técnico Fapesp).

ANSOFF, H. I.; DECLERK, R. P.; HAYES, R. L. (1981). Do planejamento estratégico à administração estratégica. Tradução de Carlos R. V. de Araújo. São Paulo: Atlas.

ANSOFF, H. I. (1993). Implantando a administração estratégica. 2. ed. São Paulo: Atlas.

ANSOFF, H. I.; MCDONNELL, E. J. (1984). Implanting strategic management. Englewood Cliffs: Prentice Hall.

ARAGÃO, C. V. (1997). Burocracia, eficiência e modelos de gestão pública: um ensaio. Revista do Serviço Público. Ano 48, n.3, p.104-131, Set./Dez.

ARAÚJO, A. O. (2001). Contribuição ao estudo de indicadores de desempenho de empreendimentos hoteleiros, sob o enfoque da gestão estratégica. 2001. 160p. Tese 
(Doutorado) - Faculdade de Economia, Administração e Contabilidade, Universidade de São Paulo, São Paulo. $\begin{array}{llll}\text { ABIH - ASSOCIAÇAO BRASILEIRA DA INDÚSTRIA DE HOTÉIS. (2007). Informação } \\ \text { sobre } & \text { ranking } & \text { hoteleiro } & \text { brasileiro. }\end{array}$ <http://www.abih.com.br/principal/noticias>. Acesso em: 26 fev. 2007.

.Perfil da hotelaria nacional. (2007). Disponível em: <http://www.abih.com.br/site.php>. Acesso em: 1 ago. 2007.

ASSOCIAÇÃO BRASILEIRA DE NORMAS TÉCNICAS. (1994). NBR ISO 8402:1994: Gestão da qualidade e garantia da qualidade - Terminologia. Rio de Janeiro.

ATTADIA, L.C. L; MARTINS, R.A. (2003). Medição de desempenho como base para evolução da melhoria contínua. Revista Produção, v.13, n.2, p. 23 - 41.

ATTADIA, L.C. L. (2004). Uso da medição de desempenho para alinhar e comunicar a estratégia: uma analise critica do Balanced Scorecard. 179p. 2004. Dissertação (Mestrado). São Carlos. Universidade Federal de São Carlos.

ATKINSON, A. A.; WATERHOUSE, J. H.; WELLS, R. B. (1997). A stakeholder approach to strategic performance measurement. Sloan management review, v. 38, n. 3, p. 25-37.

BANCO CENTRAL DO BRASIL. (2009). Indicadores Econômicos. Disponível em: < www.bcb.gov.br/?INDECO>. Acesso em: jan. 2009.

BANDEIRA, A. A. (1997). Redes de indicadores de desempenho para gestão de uma hidrelétrica. 1997. São Paulo. Dissertação (Mestrado). Universidade de São Paulo - Escola Politécnica.

BANKER, R. D.; CHANG, H.; PIZZINI, M. J. (2004). The balanced scorecard: judgmental effects of performance measures linked to strategy. The accounting Review. v.79, n.1, p.1-23, Jan.

BARNARD, I. C. As funções do executivo. São Paulo: Atlas, 1971.

BARRETO, M.; BANDUCCI JUNIOR, A. (2004). Turismo e identidade local: uma estatística aplicada ao turismo e hotelaria. Campinas: Papirus.

BARRETO, M. Planejamento e organização em turismo. (1991). Campinas: Papirus.

BEAVER, G.; LASHLEY, C; STEWART, J. (1998). Management Development. In Thomas, R. (Ed) The management small tourism \& hospitality firms. London: Cassell.

BENZE, R. P. (2008). O administrador de pequenas empresas. In: Administrar é: a evolução do trabalho do administrador por Edmundo Escrivão Filho e Sérgio Perussi. São Carlos: RiMa. Cap. 12, p.191-207.

BERRY, L.; PARASURAMAN, A. (1992). Serviços de marketing: competindo através a qualidade. São Paulo: Maltese-Norma.

BESSOM, R. M. (1973). Unique aspects of marketing of services. Arizona Business. v. 20, n. 9 , p. 8 , Nov. 
BITITCI, U.S. et al. (1998). Integrated performance measurement systems: implementation case studies. In: INTERNATIONAL CONFERENCE OF MANUFACTURING VALUE CHAIN, 1998, Troon. Prodedings... Troon: Kluver Academic, p.189.

BONGERTZ., V. O dia-a-dia na pesquisa científica: considerações éticas. In: Carneiro, F. (Org.). A Moralidade dos Atos Científicos - questões emergentes dos Comitês de Ética em Pesquisa, Rio de Janeiro, FIOCRUZ, p.1-7, 1999.

BOND, T.C. (1999). The role of performance measurement in continuous improvement. International Journal of Operations \& Production Management, Bradford, v.19, n.12, p.1318-1334.

BONELLI, R.; FLEURY, P.; FRITSCH, W. (1994). Indicadores macroeconômicos do desempenho competitivo. Revista de Administração. São Paulo. v.29, n.2, p.13-19, abr./jun.

BORGES JÚNIOR, A. A. LUCE, F. B. (2000). Estratégias emergentes ou deliberadas: um estudo de caso com os vencedores do prêmio "Top de Marketing da ADVB". Revista de Administração de Empresas. v. 40, n. 3, Jul./Set., p.36-44.

BORTOLI NETO, A. (2005). Elas não sabem como ganhar a guerra. HSM Management, v. 9, n. 50, mai./jun.

BRANCH, S. (1991). A good plan is key to business success. Black Enterprise. v. 22, n. 4, p. 68-70, Nov.

BRASIL. Ministério do Turismo. (2007). Disponível em: <http://200.189.169.141/site/arquivos/dados_fatos/Boletimdedesempenho/bdet14_v4.pdf>.

Acesso em: 1 ago.

BRASIL. Ministério do Turismo. Empresa Brasileira de Turismo. Instituto Brasileiro de Turismo. (2002). Deliberação normativa n. 429 de 23 de abril de 2002, regulamento do sistema de classificação de meios de hospedagem. Rio de Janeiro: EMBRATUR.

_. (2003). Anuário estatístico da Embratur 2003. Disponível em: $<$ http://www.braziltour.com/site/arquivos/dados_fatos/Anuario/anuario2003.pdf >. Acesso em: dia nov. 2006.

. (2006). Portal brasileiro do turismo. Disponível

em:<http://www.braziltour.com.br/>. Acesso em: 15 nov. 2008.

BRESSOLIN, M. L. (2001). Estratégia mercadológica visando melhor ocupação dos hotéis situados na região norte da ilha de Santa Catarina no período de baixa temporada. 2001.148p. Dissertação (Mestrado) - Universidade de Santa Catarina, Florianópolis.

BRITO, A. G. C. de (2008). Gestão estratégica da informação na pequena empresa: um estudo comparativo dos procedimentos empregados na pequena, média e grande empresa do setor de serviços (hotelaria). 193p. Dissertação (Mestrado) - Escola de Engenharia de São Carlos, Universidade de São Paulo, São Carlos, 2008.

BROTAS ON LINE. (2008) Região estudada. Disponível em: 〈www.brotasonline.com.br〉. Acesso em: 21 jun. 2008.

BUHALIS, D. (2000). Marketing the competitive destination of the future. Tourism Management, n.21, p. 97-116. 
CAMARGOS, M. A.; DIAS, A. T. (2003). Estratégia, administração estratégica e estratégia corporativa: uma síntese teórica. Caderno de Pesquisas em Administração, São Paulo, v.10, n. 1, jan./mar., p. 28-39.

CALDAS, P. D. (2005). Uma abordagem na gestão de custos no setor de hospedagem dos hotéis nordestinos: um estudo de caso no Rio Grande do Norte e Pernambuco. 2005. Dissertação (Mestrado em Ciências Contábeis) - Universidade de Brasília, Brasília.

CARDOZO GALDÁMEZ. E. V. C. (2007). Medição de desempenho em clusters industriais: clusters de Ibitinga e Jaú - São Paulo. 185p. 2007. Tese (Doutorado). São Carlos, Universidade de São Paulo.

CARREGARO, J. C. (2003). Proposta de indicadores de desempenho às distribuidoras de energia federalizadas do setor elétrico brasileiro. 2003. Dissertação (Mestrado). Programa de Pós-Graduação em Engenharia de Produção. Universidade Federal de Santa Catarina. Florianópolis.

CARVALHO, K. C. (2004). Gestão das informações sobre o ambiente na pequena empresa: estudo comparativo de caso sobre o processo estratégico no setor de serviços (hoteleiro) na região de Brotas-SP. 2004. 235 p. Dissertação (mestrado). Programa de Pós-graduação em engenharia de produção da Universidade de São Paulo.

CARVALHO, L. (1995). Indicadores de desempenho gerencial. Apostila (Projeto Gestão Empresarial e Qualidade) - Serviço Nacional da Indústria (SENAI). Federação das Indústrias do estado do Rio Grande do Sul (FIERGS), Porto Alegre.

CARVALHO, M. M. (2002). Selecionando projetos seis sigma. In: ROTONDARO. Seis Sigma. São Paulo: Atlas, p.49-70.

CARVALHO, N. V. (2000). Turismo e hotelaria: desenvolvendo e economia. São Paulo: Atlas.

CASTELLI, G. (2000). Administração Hoteleira. 7 ed. Caxias do Sul: Educs.

CELESTINO, M. S. (2003). Utilização de indicadores financeiros e não-financeiros na gestão de hotéis no Rio Grande do Norte: um estudo sob a ótica do Balanced Scorecard. 2003. Dissertação (Mestrado). Programa Multiinstitucional e Inter-Regional de Pós-Graduação em Ciências Contábeis. Universidade de Brasília/Universidade Federal da Paraíba/Universidade Federal de Pernambuco e Universidade Federal do Rio Grande do Norte. Natal.

CERTO, S. S.; PETER, J. P. (2005). Administração estratégica: planejamento e implantação da estratégia2. ed. São Paulo: Prentice Hall.

CERVO, A. L. (1983). Metodologia científica. 3. ed. São Paulo: MC Graw-Hill do Brasil.

CHAGAS, A. T. R. O questionário na pesquisa científica. São Paulo, v. 1, n. 1, p. 1-14, FECAP, mar. 2000.

CHANG, R.; MORGAN, M. W. (2000). Performance Scorecards measuring the right things in the real world. New York: Jossey-Bass, 160p.

CHASE, R. B.; GARVIN, D. A. (1989). The service factory. Harvard Business Review. p. 6166 , jul./aug. 
CHIAVENATO, I. (2000). Administração: teoria, processo e prática. São Paulo Makron Books.

CIRCUITOS PAULISTAS. (2009). Disponível em: <http://www.saopaulo.tur.br/circuitospaulista/>. Acesso em: 16 fev. 2009.

DAFT, R. L. (1999). Administração. 4. ed. Rio de Janeiro: LTC.

DENZIN, N. K; LINCOLN, Y. S. (2005) Handbook of Qualitative Research. Thousand Oaks: Sage.

DE ROLT, M. I. P. (1998). O uso de indicadores para a melhoria da qualidade em pequenas empresas. 1998. Dissertação (Mestrado). Universidade Federal de Santa Catarina Programa de Pós Graduação em Engenharia de Produção. Florianópolis.

DIAS, C.M.M. (1990). Home away from home - evolução, caracterização e perspectivas da hotelaria: um estudo compreensivo. 1993. p.212. Dissertação (Mestrado) - Ciência da Comunicação, Universidade de São Paulo, São Paulo.

DRUCKER, P.F. (1981). Prática da administração de empresas. São Paulo: Pioneira.

DUARTE, V.V. (1996). Administração de sistemas hoteleiros: conceitos básicos. São Paulo: SENAC.

DUARTE, R. (2002). Pesquisa qualitativa: reflexões sobre o trabalho de campo. Cadernos de Pesquisa, n. 115, março/ 2002, p. 139-154.

ESCRIVÃO FILHO, E. (1995). A Natureza do trabalho do executivo: uma investigação sobre a adequação da Teoria Administrativa para as pequenas e médias empresas de Joinville-SC. 1995. 272p. Tese (Doutorado) - Universidade Federal de Santa Catarina, Florianópolis.

(2006). Pequena empresa e administração estratégica: reconhecendo especificidades, restrições e facilitadores com o mapa organizacional. 2006. 170p. Tese (Livre Docência). Escola de Engenharia de São Carlos, Universidade de São Paulo, São Carlos.

ESCRIVÃO FILHO, E. et al. (2005). Compreendendo a dinâmica das pequenas empresas: mapa organizacional como ferramenta da ação administrativa. Revista Matiz, Matão, v.1, n.1, p.20 40 .

ETHOS - INSTITUTO ETHOS DE PESQUISA. (2008). A pesquisa quantitativa, qualitativa e estudo de casos. Disponível em: <http://www.ethos.com.br〉. Acesso em: 18 set. 2008.

ETZIONI, A. (1978). Organizações complexas: estudo das organizações em face dos problemas sociais. São Paulo: Atlas.

EYNG, I. S.; MACHADO, L. C.; REIS, D. R.; FRANCISCO, A. C. (2005). Learning organizations: um diagnóstico de utilização. UEPG Ciências Humanas, Ciências Sociais, Apl., Ling., Letras e Artes, Ponta Grossa, ed.13, n.2, p.33-41, dez.

FACHIN, O. (2002). Fundamentos de metodologia. 3. ed. São Paulo: Saraiva.

FANTINI, L.B.D. (2004). Arquitetura hoteleira: avaliação de duas categorias na cidade de São Paulo. 2v. 2004. Dissertação (Mestrado) - Faculdade de Arquitetura e Urbanismo, Universidade de São Paulo, São Paulo. 
FECHIO, J. A. (2001). Planejamento estratégico. Computerworld. Disponível em:<http://www.sit.com.br/SeparataGe0046.htm>. Acesso em: 10 mar. 2001.

FERRAZ, C. A. (2003). Proposta de um método abrangente para o diagnóstico da medição de desempenho organizacional. 119p. 2003. Dissertação (Mestrado). São Carlos, Universidade Federal de São Carlos.

FERREIRA, A B. H. (1993). Minidicionário da língua portuguesa. 3. ed. Rio de Janeiro: Nova Fronteira.

FILION, L. J. (1999). Diferenças entre sistemas gerenciais de empreendedores e operadores de pequenos negócios. Revista de Administração de Empresas. v. 39, n. 4, out/dez, p.6-20.

FINGER, M.; BRAND, S. B. (2001). Conceito de organização de aprendizagem aplicado à transformação do setor público: contribuições conceituais ao desenvolvimento da teoria. In: EASTERBY-SMITH, M.; BURGOYNE, J.; ARAUJO, L. (Eds.). Aprendizagem Organizacional e Organização de Aprendizagem: Desenvolvimento na Teoria e na Prática. São Paulo: Atlas.

FISCHMANN, A. A.; ALMEIDA, M. I. R. (1991). Planejamento estratégico. 2.ed. São Paulo: Atlas.

FISCHMANN, A. A. (1987). Implementação de estratégias: identificação e análises de problemas. 1987. 200p. Dissertação (Mestrado) - Faculdade de Economia Administração e Contabilidade. Universidade de São Paulo, São Paulo.

FITZSIMMONS, J. A.; FITZSIMMONS, M. J. (2000). Administração de serviços: operação, estratégias e tecnologia de informação. 2. ed. Porto Alegre: Bookman.

FLEURY, A. (1995). Quality and productivity in the competitive strategies of Brazilian industrial enterprises. World Development, v.23, n.1, p. 73-85.

FRANCO, A. L.; NORIEGA, P. B. M. (2000). Cost and control in the hospitality industry. New Jersey: Prentice-Hall.

FRIGO, M. L. (2002). Strategy-focused performance measures. Strategic Finance. v. 84, n.3, p. 10-15, Set.

GAITHER, N.; FRAZIER, G. (2001). Administração da produção e operações. 8. ed. São Paulo: Pioneira Thomson Learning.

GARENGO, P.; BIAZZO, S.; BITITCI, U. S. (2005). Performance measurement systems in SMEs: a review for a research agenda. International Journal of Management Reviews. v.17, n.1, p.25-47.

GARTNER, W. B. (1985). A conceptual framework for describing the phenomenon of new venture creation. Academy of Management Review. v.10, n.4, p.696-706.

GARG, R. K.; CHAN, K. K. (1997). Service orientation and small business marketing. Journal of Professional Services Marketing. v.15, n.2., p.131, ABI/INFORM Global.

GARVIN, D. A; NAYAK, P. R.; MAIRA, A. N.; BRAGAR, J. L. (1998). Learning organization: aprender a aprender. HSM Management. 9 julho/ agosto. 
GIANESI, I. G. N.; CORRÊA, H. L. (1994). Administração estratégica de serviços. São Paulo: Atlas.

GODOY, A. S. (1995a). Introdução à pesquisa qualitativa e suas possibilidades. Revista de Administração de Empresas. São Paulo, v.35, n.2, p.57-63, Mar./Abr.

(1995b) Pesquisa qualitativa: tipos fundamentais. Revista de Administração de Empresas. São Paulo, v.35, n.3, p.20-29, Mai/Jun.

GOLD, J. (1995b). A empresa que aprende baseada no conhecimento. In: CLARKE, T.; MONKHOUSE E. Repensando a Empresa. São Paulo: Pioneira.

GOMES, J. S.; SALAS, J. M. A. Controle de gestão: uma abordagem contextual e organizacional. 2.ed. São Paulo: Atlas, 1999.

GONÇALVES, A.; KOPROWSKI, S.O. (1995). Pequena empresa no Brasil. São Paulo: Imprensa Oficial do Estado; Editora da Universidade de São Paulo.

GORINI, A. P. F.; MENDES, E. F. (2005). Setor de Turismo no Brasil: segmento de hotelaria. BNDES Setorial. Rio de Janeiro, n. 22, p. 111-150, set.

GRONROOS, C. (1995). Marketing: gerenciamento e serviços: a competição por serviços na hora da verdade. Rio de Janeiro: Campus.

HAGUETTE, T.M.F. (2001). Metodologias qualitativas na sociologia. Petrópolis: Vozes.

HALL, C.M. (1996). Tourism and politics: policy power and place. England: Wiley.

HALL, R H. (1984). Organizações: estrutura e processos. 3. ed. Rio de Janeiro: Prentice-Hall.

HAMBRICK, D. C. (1980). Operationalizing the concept of business-level strategy in research. Academy of Management Review. v. 5, n. 4, p.567-575.

HAMEL; J.R. PRAHALAD, C. K. (1991). Corporate imagination and expeditionary marketing. Harvard Business Review, p. 2-11, jul./aug.

HAMPTON, D. R. (1992). Administração contemporânea: teoria, prática e casos. 3. ed. São Paulo: McGraw - Hill.

HARRINGTON, H. J. (1993). Aperfeiçoando processos empresariais. Tradução de Luiz Liske. São Paulo: Makron Books.

HARRIS, P. J.; MONGIELLO, M. (2001). Key performance indicators in European hotel properties: general managers' choices and company profiles. International Journal of Contemporary Hospitality Management. v.13, n.3, p. 120-127.

HAUSER, J.R.; KATZ, G. (1998). Metrics: You Are What You Measure. European Management Journal.v. 16, n. 5, p. 517-528.

HAYATI, D; KARAMI, E.; SLEE, B. (2006). Combining qualitative and quantitative methods in the measurement of rural poverty. Social Indicators Research, v.75, p.361-394, springer.

HAX, A.; MAJLUF, N. (1988). The concept of strategy and the strategy formation process. Interfaces, v. 18, n. 3, p.99-109, may/jun. 
HERACLEOUS, L. (1998). Strategic thinking or strategic planning? Long Range Lanning, v. 31, n. 3, p. 481-487, jun.

HESKETT, J.L.; SASSER, W.E.; SCHLESINGER, L.A. (2002). Lucro na Prestação de Serviços:como crescer com a lealdade e a satisfação dos clientes. Rio de Janeiro: Campus.

HILLIDGE, J. (1990). Planning for growth in a small company. Academy of Management Journal. London, v. 23, n. 3, p. 76-81, Jun.

HO, S. J. K.; McKAY, R. B. (2002). Balanced Scorecard: two perspectives. The CPA Journal. v. 72 , n. 3, p. $20-25$, Mar.

HOTEL INVESTMENT ADVISORS. (2006). Hotelaria em números. Brasil. São Paulo: HIA.

HOURNEAUX JÚNIOR, F. (2005). Avaliação de desempenho organizacional: estudo de casos de empresas do setor químico. 160p. 2005. Dissertação (Mestrado). Universidade de São Paulo, São Paulo.

HREBINIAK, L. G. (2006).Fazendo a estratégia funcionar. Porto Alegre: Bookman.

HRONEC, S. M. (1994). Sinais vitais. São Paulo: Makron Books.

HUDSON, M. (2001). Introducing integrated performance measurement into small and medium sized enterprises. 2001. 189p. Thesis - PhD - Plymouth Business School, University of Plymouth.

HUDSON, M.; SMART, A.; BOURNE, M. (2001). Theory and practice in SME performance measurement systems. International Journal of Operations \&Production Management, v. 21 n. 8, p. 1096-1115.

IGNARRA, L. R. (2002). Fundamentos do turismo. São Paulo: Pioneira.

INÁCIO JÚNIOR, E. Padrões de inovação em pequenas e médias empresas e suas implicações para o desempenho inovativo e organizacional. 2008. 261p. Tese (Doutorado) Programa de Pós-Graduação em Política Científica e Tecnológica, Universidade Estadual de Campinas, São Paulo.

INSTITUTO BRASILEIRO DE GEOGRAFIA E ESTATÍSTICA - IBGE. (2007). Cadastro Central de Empresas - CEMPRE. Estatísticas do Cadastro Central de Empresas 2005. Rio de Janeiro, p.1-154.

(2007) Atividades relacionadas ao turismo geram R\$ 31,1 bilhões. Disponível em: http://www.ibge.gov.br/home/presidencia/noticias/noticia_visualiza.php?id_noticia=804. Acesso em 15 de jun.2009.

JULIEN, P. A. (1997). Introduction. In: JULIEN, P. A. (org.) Les PME: lilan et perspectives. Quebec (Canadá): Les Press Inter Universitaices.

(1993). Small businesses as a research subject: some reflections on knowledge of small businesses and its effects on economic theory. Small Business Economics, v.5, n.2, June.

England: Ashgate.

(1998) The state of the art in small business and entrepreneurship. Aldershot, 
JOHNSON, H. T.; KAPLAN, R. S. (1993). Contabilidade gerencial: a restauração da relevância da contabilidade nas empresas. Rio de Janeiro: Campus.

KAYDOS, W. (1991). Performance measurement and performance management. In: Measuring managing and maximizing performance. Portland: Productivity, Cap.3, p.33-52.

KAPLAN, R. S. (1998). Balanced scorecard. HSM Management. v. 11, nov-dez, p.120-126.

KAPLAN, R. S.; BEINHOCKER, E. D. (2003). The real value of strategic planning. MIT Sloan Management Review, v. 44, n. 2, winter.

KAPLAN, R. S.; NORTON, D. P. (1992). The balanced scorecard - measures that drive performance. Harvard Business Review, v. 70, n. 1, p. 70-79.

(1996). The Balanced scorecard: translating strategy into action. Boston: Harvard Business School Press.

(1996). Using the balanced scorecard as a strategic management system. Harvard Business Review, New York, v.74, n.1, p.75-85, Jan. /Feb.

Review, Berkeley, v.39, n.1, p.53-79.

(1997). A estratégia em ação: Balanced Scorecard. Tradução de Luis Euclides Trindade Frazão Filho. 13 ed. Rio de Janeiro: Campus, p. 344.

(1999). Building a strategic: focused organization. Balanced Scorecards Report. v.1, n.1, p. $1-6$, Sep/Oct.

(2001). Transforming the balanced scorecard from performance measurement strategic management: part I. Accounting Horizons, Sarasota, v.15, n.1, p.87-104, Mar.

KIYAN, F.M. (2001). Indicadores de desempenho como suporte estratégico. 2001. 118p. Dissertação (Mestrado) - Programa de Pós-Graduação em Engenharia de Produção, Universidade de São Paulo, São Paulo.

KOONTZ, H.; O’DONNEL, C. (1982). Princípios de administração. 13. Ed. 2v. São Paulo: Pioneira.

KOTEY, Bernice; SLADE, Peter. (2005). Formal human resource management: practices in small growing firms. Journal of Small Business Management. v. 43, n.1, p.16-40.

KOTLER, P. (1998). Administração de marketing: análise, planejamento, implementação e controle. São Paulo: Atlas.

. (2002). Marketing para o século XXI. São Paulo: Futura.

KRUGLIANSKAS, I. (1996). Tornando a pequena e média empresa competitiva. São Paulo: IEGE.

LAGE, J. (2007b). SP concentra mais de $40 \%$ da receita de serviços de turismo. Folha de S. Paulo. São Paulo, 1 fev. Dinheiro, Caderno B, p.8.

(2007). Brasil é o $36^{\circ}$ destino mais procurado. Folha de S. Paulo. São Paulo, 25 fev. 2007. Dinheiro, Caderno B, p.6. 
LAGE, B. H. G. (2000). Turismo: teoria e prática. São Paulo: Atlas.

LANTElME, E. M. V. (1994). Proposta de um sistema de indicadores de qualidade e produtividade para a construção civil. 111p. 1994. Dissertação (Mestrado). Porto Alegre, Universidade Federal do Rio Grande do Sul Paulo.

LA TORRE, F. de. (2001). Administração hoteleira. São Paulo: Roca.

LAWRENCE, P. R.; LORSCH, J. W. (1977). O desenvolvimento de organizações: diagnóstico e ação. São Paulo: Edgard Blucher.

LAWSON, F. (2003). Hotéis e resorts: planejamento, projeto e reforma. Porto Alegre: Bookman.

LEEDY, P.; ORMROD, J. E. L. Practical research: planning and design. 8. ed. Pearson: Feb. 2004. Cap. 2.

LEE, R.; DALE, B. (1998). Policy deployment: an examination of the theory. International Journal of Quality and Reliability Management, Bradford, v.15, n.5, p.520-540.

LEITE, D. C. C. (2004). Investigação sobre a medição de desempenho em pequenas empresas hoteleiras do nordeste brasileiro. 114p. 2004. Dissertação (Mestrado). Universidade de Brasília/Universidade Federal da Paraíba/Universidade Federal de Pernambuco e Universidade Federal do Rio Grande do Norte - Programa Multiinstitucional e Inter-Regional de Pós-Graduação em Ciências Contábeis, João Pessoa..

LEMOS, C. (1999). Inovação na era do conhecimento. In: LA ROVERE, R. As Pequenas e médias empresas na economia do conhecimento: implicações para políticas de inovação. Rio de Janeiro: Campus. Cap.6, p.145-162.

LEONE, N.M.C.P.G. (1991). A Dimensão física das pequenas e médias empresas. Revista de Administração de Empresas, São Paulo, v.31, n.2, p.53-59, abr./jun.

(1999). As Especificidades das pequenas e médias empresas. Revista de Administração, São Paulo, v.34, n.2, p.91-94, abr./jun.

LERNER, M.; HABER, S. (2000). Performance factors of small tourism ventures: the interface of tourism, entrepreneurship and the environment. Journal of Business Venturing. v. 16, p. 77-100, New York.

LIMA, E. O. (2001). As definições de micro, pequena e media empresas brasileiras como base para a formulação de políticas públicas. EGEPE - ENCONTRO DE EMPREENDEDORISMO E GESTÃO DE PEQUENAS EMPRESAS. 2., Londrina. Anais... Londrina, 2001. 1 CD-ROM.

LONGENECKER, J. G.; MOORE, C. W.; PETTY, J. W. (1997). Administração de pequenas empresas: ênfase na gerência empresarial. São Paulo: Makron Books.

LORANGE, P. (1982). Implementation of strategic planning. Englewood Cliffs: Prentice Hal, Inc., 231p.

LOTTA, G. S. (2002). Avaliação de desempenho na área pública: perspectivas e propostas frente a dois casos práticos. RAE Eletrônica. v.1, n.1, p.1-12, jul./dez. 
LOVELOCK, C. (1991). Services Marketing. Prentice-Hall: New York.

LOVELOCK, C.; WRIGTH, L. (2004). Serviços: marketing e gestão. São Paulo: Saraiva.

LOVEMAN, G.; SENGENBERGER, W. (1990). Introduction. In: THE RE-EMERGENCE of small enterprises. Geneva: OIT.

LUNKES, R. J. (2004). Manual de contabilidade hoteleira. São Paulo: Atlas.

LYGUORY, S.; GRAY, W. S. (1990). Hotel and motel: management and operations. New Jersey: Prentice-Hall.

LYNCH, P. (1999). Host attitudes towards guests in the homestayctor. Tourism and Hospitality Research. v.1, n.2, p-119-144.

MARCONI, M. A.; LAKATOS, E. M. Técnicas de pesquisa: planejamento e execução de pesquisas, amostragens e técnicas de pesquisa, elaboração, análise e interpretação de dados. São Paulo: Atlas, 1999.

MARRIOTTO, F. L. (2003). Mobilizando estratégias emergentes. Revista de Administração de Empresas, Rio de Janeiro, v. 43, n. 2, p. 78-93.

MARQUES, J. A. (2003). Introdução à Hotelaria. Bauru, SP: EDUSC.

MACHADO, I, P. V. (2000). Relacionamento e satisfação do cliente como alternativas de sustentação das pequenas e médias empresas no Brasil. Revista Brasileira de Administração. Brasília. v.10, n.30, p.54-64, Set.

MACHADO, M. R.; VERAS MACHADO, M. A.; HOLANDA, F. M. A. (2008). Indicadores de desempenho utilizados pelo setor hoteleiro da cidade de João Pessoa/PB. Disponível em: <www.congressoeac.locaweb.com.br/artigos62006/598.pdf>. Acesso em: 12 Jul. 2008.

MARCONI, M. A.; LAKATOS, E. M. (1999). Técnicas de pesquisa: planejamento e execução de pesquisas, amostragens e técnicas de pesquisa, elaboração, análise e interpretação de dados. São Paulo: Atlas.

MARIOTTO, F. L. (2003). Mobilizando estratégias emergentes. Revista de Administração de Empresas, Rio de Janeiro, v. 43, n. 2, p. 78-93.

MARTINS, R. A. (1998). Sistemas de medição de desempenho: um modelo para estruturação do uso. 1998. Doutorado (Tese), Escola Politécnica, Universidade de São Paulo, São Paulo.

MASSEY, C. (2004). Employee practices in New Zealand SMEs. Employee relation. v.26, n.1, p.94-105.

MAXIMIANO, A. (2004). Introdução à administração. 6. ed. São Paulo: Atlas.

McGEE, J.; PRUSAK, L. (1995). Introdução à administração. 6. ed. São Paulo: Atlas.

MEDLIK, S.; INGRAM, H. (2000). The business of hotels. 4.ed. Oxford: Butterworth Heinemann.

MEGGinsON, L. C; MOSLEY, D. C.; PIETRI JUNIOR, H. P. (1986). Administração: conceitos e aplicações. São Paulo: Harbra Ltda. 
MELLO, T. A. Investigação educativa: análise e reflexão através dos pressupostos epistemológicos. Resenha de: GAMBOA, S. S. Fundamentos para La investigación: presupuestos epistemológicos que orientam al investigador. 1998. Unicamp: Campinas, 2005.

MENDES G. H. S; TOLEDO, J.C. (2002). Qualidade em serviços: o papel da função de desenvolvimento de novos serviços. XXII Encontro Nacional de Engenharia de Produção Curitiba - PR, 23 a 25 de outubro de 2002. ENEGEP 2001. ABEPRO

MENDES, J. C. (2002) A abordagem qualitativa e quantitativa no estudo de caso. Disponível em: <http://www.qofisto.dei.vc.p/capsi2002/workshop/caps/3-josemendes.pdf>. Acesso em: 20 jun. 2008.

MIGLIATO, A. L. T.; ESCRIVÃO FILHO, E. (2004). A pequena empresa e suas especificidades: uma proposta de classificação fundamentada em um modelo de concepção organizacional. In: VII Seminários em Administração - SemeAd, 10 e 11 de agosto de 2004, São Paulo: Faculdade de Economia, Administração e Contabilidade - FEA/USP. 1CD-ROM. p. $1-14$.

MigliATO, A. L. T. (2004). Planejamento Estratégico Situacional Aplicado à Pequena Empresa: estudo multicasos em empresas do setor de serviços (hoteleiro) da região de Brotas SP. 223p. Dissertação (Mestrado) - Escola de Engenharia de São Carlos, Universidade de São Paulo, São Carlos.

MINISTÉRIO DO TURISMO. Empresa Brasileira de Turismo. Instituto Brasileiro de Turismo. (2003). Anuário estatístico da Embratur 2003. Disponível em: <http://www.braziltour.com/site/arquivos/dados_fatos/Anuario/anuario2003.pdf>. Acesso em: nov. 2006.

MINTZBERG, H. (1983). A estrutura das organizações. In: MINTZBERG, H.; QUINN, J. B. O processo da estratégia. Porto Alegre: Bookman, 2001.

MINTZBERG, H. (2004). Ascensão e queda do planejamento estratégico. Tradução Maria A. Carpigiani. Porto Alegre: Bookman.

(2003). Criando organizações eficazes: estruturas em cinco configurações. Tradução de Ailton B, Brandão. 2. ed. São Paulo: Atlas.

. (1978). Patterns in strategy formation. Management Science. v.29, n. 9, p. 934-48. Jan. /Fev.

(1994). The fall and rise of strategic planning. Harvard business Review, p. 107- 114,

MINTZBERG, H.; AHLSTRAND, B.; LAMPEL, J. (2000). Safári de estratégia. Tradução de Nivaldo Montingell Jr. Porto Alegre: Bookman.

MINTZBERG, H.; LAMPEL, J. (2000). Reflexão sobre o processo estratégico. Revista Portuguesa de Gestão. III série 15: 2 (Primavera 2000) p. 24-33. Disponível em: <http://www.janelanaweb.com/manageme/sloan2.htm>. Acesso em: 15 set. 2008.

MINTZBERG, H.; QUINN, J. B. (2001). O processo da estratégia. Sunderland Cook. 3. ed. Porto Alegre: Bookman. 
MINTZBERG, H.; WATERS, J. A. (1985). Os strategies, deliberate and emergent. Strategic Management Journal. v. 6, n.3, p.257-272, Jul-Sep.

MIRANDA, L.C.; SILVA, J.D.G. (2002). Medição de desempenho. In: SCHIMIDT, P. (Org.). Controladoria: agregando valor para a empresa. Porto Alegre: Bookman, 2002. p.130-153.

MIRANDA, L. C.; WANDERLEY, C. A.; MEIRA, J. M. (1999). Garimpando na imprensa especializada: uma metodologia alternativa para a coleta de indicadores de desempenho gerencial. In: CONGRESSO INTERNACIONAL DE CUSTOS, 6. , 1999. Disponível em: <www.dep.ufscar.br>. Acesso em 4 abr. 2007.

MIRANDA, MC-DOWELL P.(1980). Organização e métodos. 5. ed. São Paulo: Atlas.

MONTANA, P. J.; CHARNOV, B. H. Administração. São Paulo: Saraiva, 1998.

MONTE, E. F. (1997). Administração estratégica de serviços: aspectos da compreensão dos serviços dos clientes. Caderno de Pesquisa em Administração, v. 2, n. 5, $2^{\circ}$ sem.

MOREIRA, D. A. (1996). As dimensões do desempenho em manufatura e serviços. São Paulo: Pioneira.

MORGAN, R. E.; STRONG, C. A. (2003). Business Performance ands dimensions of strategic orientation. Journal of Business Research. v.56, p. $163-176$.

MORRIS, J. M. (1991). Iniciando uma pequena empresa com sucesso: como fugir das armadilhas e resistir firmemente aos primeiros anos cruciais. São Paulo, Makron, McGraw-Hill.

MORRISON, A. (1998). Small Firm Statistics: A Hotel Sector Focus. The services industries Journal. v. 18, n. 1, p. $132-142$.

MOTTA, F. G. (2000). Fatores condicionantes na adoção de métodos de custeio em pequenas empresas: estudo multicasos em empresas do setor metal-mecânico de São

Carlos/SP. Dissertação (Mestrado) - Escola de Engenharia de São Carlos, Universidade de São Paulo, São Carlos.

MOTTA, F. C. P.; PEREIRA, L. C. B. (1980). Introdução à organização burocrática. São Paulo: Brasiliense.

MOTTA, P. R. Gestão contemporânea: a ciência e a arte de ser dirigente. Record, 1991. Propostas para uma gestão efetiva municipal. 2.ed. São Paulo: FGV, 2003.

MÜLLER, C. J. (2003). Modelo de gestão integrando planejamento estratégico: sistemas de avaliação de desempenho e gerenciamento de processos (MEIO - Modelo de Estratégia, Indicadores e Operações). 2003.246p. Tese (Doutorado em Engenharia) - Universidade Federal do Rio Grande do Sul.

MULLINS, L. J. (2004). Gestão da hospitalidade e comportamento organizacional. 4.ed. Porto Alegre: Bookman.

NAKAMURA, M. M. (2000). Estratégia empresarial para as pequenas e médias empresas: recomendações práticas para empresas industriais do setor metal-mecânico de São Carlos-SP. 
2000. 241p. Dissertação (Mestrado em Engenharia de Produção) - Escola de Engenharia de São Carlos, Universidade de São Paulo, São Carlos.

NAURI, M. H. C. (1998). As medidas de desempenho como base para a melhoria continua de processos: o caso da fundação de amparo à pesquisa e extensão universitária (FAPEU). 1998. Universidade Federal de Santa Catarina. Curso de Pós Graduação em Engenharia de Produção. Florianópolis.

NEELY, A; GREGORY, M.; PLATTS, K. (1995). Performance measurement system design a literature review and research agenda. International Journal of Operations \& Production Management, Bradford, v.5, n.4, p.80-116.

NEELY, A. RICHARDS, H.; MILLS, J.; PLATTS, K.; BOURNE, M. (1997). Designing performance measures: a structured approach. International Journal of Operations \& Production Management. Bradford. v.17, n.11, p.1131-1152.

NEELY, A. (1998). Measuring business performance. London: The Economist Newspaper and Profile Books.

NORREKLIT, H. (2000). The balance on the balanced scorecard: a critical analysis of some of its assumptions. Management Accounting Research. v. 11, p.65-88.

NUNES, L. C. (2003). Programa é direcionado a pequenas hospedagens. Pequenas Empresas, Grandes Negócios. São Paulo. Disponível em: <www.pegn.com.br> . Acesso em: 04 jul.

OGDERS, P. (1998). Management Development Needs of Individual Owners Managers of SMES in the Hospitality Sector. Conference Proceedings, 7th Annual Hospitality Research Conference. Glasgow Caledonian University, Glasgow.

OKE, A.; BURKE, G.; MYERS, A. (2007). Innovation types and performance in growing UK SMEs. International Journal Operations \& Production Management. v.27, n.7, p.735-753.

OLIVIER, S.; RILEY, D. (1996). Perceptions and practice of corporate communication in small businesses. Corporate Communications, ABI/INFORM Global, local, p.12-18.

OLIVEIRA, D. P R. (1999). Planejamento estratégico. 14. ed. São Paulo: Atlas.

(2001). Estratégia competitiva e vantagem competitiva: como estabelecer, implementar e avaliar. 3. ed. São Paulo: Atlas.

OLIVEIRA, M. A. L. (1994). Qualidade: o desafio da pequena e média empresa. Rio de Janeiro: Qualitymark.

OLSON, E. M.; SLTAER, S. F. (2002). The balanced scorecard: competitive strategy and performance. Business Horizons. v. 45, n.3, p.11-17.

OMT - ORGANIZAÇÃO MUNDIAL DO TURISMO. (2005). Excellence in public private tourism destination management. Disponível em: 〈http://www.world-tourism.org>. Acesso em: 5 Dez. 2005.

(1998). Guide for local authorities on developing sustainable tourism. A Tourism and Environment Publication. Madrid: Organización Mundial del Turism. 1998. cap. 1, p.21. Disponível em: <http://www.would-tourism.org/publications/PR 1016-1.html>. Acesso em: 05 set. 2007. 
OTTO, J. E.; RITCHIE, J R B. (1996). The service experience in tourism. Tourism Management. v. 17, n. 3, p. $165-174$.

PARASURAMAN, A.; ZEITHAML, V. A.; BERRY, L. L. (1990). Delivering Quality Service. New York: The Free Press.

PEREIRA, C. A. (1999). Ambiente, empresa, gestão e eficácia. In: CATELLI, A. (coord.). Controladoria: uma abordagem de gestão econômica - GECON. São Paulo: Atlas.

PERRIN, B. (1998). Effective use and misuse of performance measurement. American Journal of Evaluation, v.19, n.3, p.367-379, Sept.

PETROCCHI, M. (2002). Turismo: planejamento e gestão. São Paulo: Futura.

PREVIDELLI; J. J.; MEURER, V. (2005). Gestão da micro, pequena e média empresa no Brasil: uma baordagem multidimensional. In: REIS, A. P.; ESCRIV ÃO FILHO, E. Análise das barreiras existentes para a prática do treinamento na pequena empresa. Cap. III, p.87-110. Maringá: Unicorpore.

PHILLIPS, A. P. (1996). Strategic planning and business performance in the quoted UK hotel sector: results of an exploratory study. International Journal Hospitality Management. v. 15 , n. 4 , p. $347-362$.

POPADIUK, S.; PEREIRA, L. F. P.; FRANKLIN, M. A.; GARDESANI, R.; MIYABARA, W. (2006). Arquitetura da informação e mensuração do desempenho: um estudo na indústria de artefatos e utensílios plásticos no Estado de São Paulo. Revista Gestão \& Produção. v.13, n.1, p.151-165, jan./abr.

PORTER, M. E. (1998). Clusters and the new economics of competition. Harvard Business Review. p. 77-90, Nov./Dec.

Elsevier.

(1999). Competição: estratégias competitivas essenciais. 13. ed. Rio de Janeiro:

. (1991). Towards a dynamic theory of strategy. Strategic Management Journal.

(1985). Competitive advantage. New York : Free Press.

PRADO JÚNIOR, S. T. (2003). Estratégias emergentes: uma proposta de síntese conceitual. In: ENCONTRO DE ESTUDOS EM ESTRATÉGIA, 1, 2003, Curitiba/PR, Anais... Rio de Janeiro: Anpad.

PRANCIC, E.; MARTINS, R. A (2003). Uma revisão teórica sobre a medição de desempenho do processo de desenvolvimento do produto. IV CONGRESSO BRASILEIRO DE GESTÃO E DESENV OLVIMENTO DE PRODUTOS. Gramado -RS, p. 1-10, 6 a 8 de outubro.

RAMOS, N. M. (1978). Aperfeiçoamento das técnicas de avaliação de desempenho na administração pública. Revista ABOP. n.4, v.1, jan./abr.

REBELO; ERDMANN, (2004). Formação de estratégias em universidades: processo formal, negociado ou construção permanente? Revista Diálogo Educacional, Curitiba, v. 4, n.11, p. 117-133, jan./abr.

RIBEIRO, S. X. (2008). Gestão estratégica da comunicação na pequena empresa: estudo comparativo de casos em empresas hoteleiras da região central do estado de São Paulo. 
210p. Dissertação (Mestrado). Escola de Engenharia de São Carlos, Universidade de São Paulo, São Carlos.

ROBBINS, S. P. (1978). O processo administrativo: integrando teoria e prática. Tradução de Wiktor Wanjtal e Isabel C. Weippert. São Paulo: Atlas.

ROTHWELL, R.; DODGSON, M. (1993). Technology - based SMEs: their role in industrial and economic change. Buckinghamshire: Interscience Enterprises.

RUMMLER, G.; BRACHE, A. P. (1994). Melhores desempenhos das empresas: uma abordagem pratica para transformar as organizações através da reengenharia. 2. ed. Makron Books.

RUSCHMANN, D. Van M. (2002). Turismo no Brasil: análise e tendências. Barueri: Manole.

SAAB, W. G. L.; DAEMON, I. G. (2001). O segmento hoteleiro no Brasil. BNDES Setorial. Rio de Janeiro, n. 13, p. 127-156, mar.

SAAB, W. G. L.; GIMENEZ, L. C. P. (2001). Flats, apart-hotéis ou hotéis-residência: caracterização e desempenho no Brasil e no município de São Paulo. BNDES Setorial. Rio de Janeiro, n. 14, p. 137-157, set.

SALÃO DO TURISMO. $3^{\circ}$ Salão do Turismo: roteiros do Brasil. Ministério do Turismo. 18 a 22 de junho de 2008. 98p. Disponível em: <http://www.sebraesp.com.br/noticias/node/2474>. Acesso em 16 fev. 2009. Turismo São Paulo: Show Case 2009. FC\&VB-SP, 178p.

SCASE, R.; GOFFEE, R. (1984). The real world of the small business owner. London: Routledge.

SCHEIN, E. H. (1982). Psicologia organizacional. Rio de Janeiro: Prentice-Hall.

SCHEWECK, C.R.; SHRADER, C.B. (1993).Effects of formal strategic planning on financial performance in small firms: a metal-analysis. Entrepreneurships Theory and Practice, p.5364, Spring.

SCHNEIDERMAN, A. M. (1999). Why balanced scorecards fail. Journal of Strategic Performance Measurement. New York. p.6-10, Jan..

SEBRAE - SERVIÇO BRASILEIRO DE APOIO ÀS MICRO E PEQUENAS EMPRESAS. (2005). Boletim estatístico de micro e pequenas empresas: observatório SEBRAE 2005. Estudos e Pesquisa. Disponível em: <www.sebraesp.com.br>. Acesso em: nov. 2006.

. (2008). Classificação das empresas segundo o número de empregados. Disponível em: <www.sebrae.org.br>. Acesso em junho de 2008.

. (2004a). Fatores condicionantes e a taxa de mortalidade de empresas no Brasil. Relatório de Pesquisa. Brasília: SEBRAE.

(2005). Sobrevivência e mortalidade das empresas paulistas de 1 a 5 anos. São Paulo: SEBRAE, 2005. Disponível em: <www.sebraesp.com.br >. Acesso em 08 mar. 2007.

SEBRAE/GOIÁS - SERVIÇO BRASILEIRO DE APOIO ÀS MICRO E PEQUENAS EMPRESAS. (2006). Cidade de Goiás precisa investir mais em lazer. Disponível em: <http://www.sebraego.com.br/site/site.do?idArtigo=1277>. Acesso em: Jan.2006. 
SELLTIZ, C.; COOK, S. W.; JAHODA, M.; DEUTSCH, M. (1974). Métodos de pesquisas nas relações sociais. São Paulo: EPU.

SENGE, P. M. A (2004). Quinta disciplina: arte e prática da organização que aprende 16. ed. São Paulo: Editora Nova Cultural.

SERSON, F. M. (2000). Hotelaria: a busca da excelência. São Paulo: Cobra.

SHARDER, C. B.; MULFORD, C. L.; BLACKBURN, V., L. (1989). Strategic and operational planning, uncertainty, and performance in small firms. Journal of Small Business Management. v. 27, n. 4, p. 45-60, Oct.

SHAW, E.; CONWAY, S. (2000). Networking and the small firm. In Carter, S. Jones - Evans, D. (Eds.) Enterprise and Small Business. Harlow: Financial Times/Prantice-Hall.

SIGAW, J.; ENZ, C.; NAMASIVAYAM, K. (2000). Adoption of information technology in U.S. hotels: strategically driven objectives. Journal of travel Research. v.39, p. 192-201, Nov.

SILVA, A. B. (1998). A pequena empresa na busca da excelência. João Pessoa: Universitária.

SILVA, E. L. da; MENEZES, E. M. (2001). Metodologia da pesquisa e elaboração de dissertação. Florianópolis, Laboratório de Ensino à Distância da UFSC. Disponível em: <http://www.eps.ufsc.br/ppgep.html>. Acesso em: agosto 2003.

SINK, S.; TUTTLE, T. C. (1989). Planning and measurement in your organization of the future. Norcross, Georgia: Industrial of industrial engineers.

SOBRAL, F.; PECI, A. (2008). Administração: teoria e prática no contexto brasileiro. São Paulo: Prentice Hall.

SOUZA, I. G.; A.; LEITE, C. M.; MIRANDA, L. C. (2002). Contabilidade gerencial: um enfoque para a tomada de decisão nas pequenas e médias empresas. VII SEACON Seminário Acadêmico de Contabilidade do Vale do São Francisco. Petrolina.

SOUZA, M. C. A. F. (1995). Pequenas e médias empresas na reestruturação industrial. Brasília: Edição SEBRAE.

STEINER, G. A. (1979). Strategic planning. New York: Free Press.

STONER, J. A. F.; FREEMAN, R. E. (1999). Administração. Rio de Janeiro: LTC.

STOREY, D. (1994). Understanding the small business sector. Routledge: London.

TAKASHINA, N. T.; FLORES, M. C. X.(1996) Indicadores da qualidade e do desempenho: como estabelecer metas e medir resultados. Rio de Janeiro: Qualitymark.

TERENCE, A.C.F.; BENZE, R. P.; ESCRIVÃO FILHO, E. (2004). A influência das características estruturais no processo de elaboração de estratégia na pequena empresa. In: Asamblea Anual del Consejo Latinoamericano de Escuelas de Administración (CLADEA). 39., 2004, Puerto Plata. Anais... Puerto Plata, República Dominicana: Pontifícia Universidad Católica Madre y Maestra, 20-24 octubre 2004, 1 CD-ROM.

TERENCE, A.C.F. (2002). Planejamento estratégico como ferramenta de competitividade na pequena empresa: desenvolvimento e avaliação e um roteiro pratica para a elaboração de 
planejamento. 2002. 211p. Dissertação (Mestrado em Engenharia de Produção) - Escola de Engenharia de São Carlos, Universidade de São Paulo, São Carlos.

(2008). Processo de criação de estratégias em pequenas empresas: elaboração de um mapa estratégico para pequenas empresas de base tecnológica do pólo de São Carlos/SP. 136 p. Tese (Doutorado) - Escola de Engenharia de São Carlos, Universidade de São Paulo, São Carlos.

TERRA, J. C. C. (2000). Gestão do conhecimento: o grande desafio empresarial, uma abordagem baseada no aprendizado e na criatividade. São Paulo: Negócio Editora.

THOMPSON Jr., A. A.; STRICKLAND III, A. J.; GAMBLE, J. E. (2008). Administração estratégica. 15. ed. São Paulo: McGraw-Hill.

THOMPSON JR, A. A.; STRICKLAND III, A. J. (2004). Planejamento estratégico: elaboração, implementação e execução. São Paulo: Pioneira.

TIFFANY, P.; PETERSON, S. D. (1999). Planejamento Estratégico. Rio de Janeiro: Campus.

TRIGO, L. G. G. (1998). Turismo básico. 2. ed. São Paulo: Senac.

. (1993). Turismo e qualidade: tendências contemporâneas. São Paulo: Papirus.

TRIVIÑOS, A.N.S. (1992). Introdução à pesquisa em ciências sociais: a pesquisa qualitativa em educação. São Paulo: Atlas.

VALLEN, G.K.; VALLEN, J.J. (2003). Check-in, check-out: gestão e prestação de serviços em hotelaria. 6. ed. Porto Alegre: Bookman.

VASCONCELOS FILHO, P; PAGNONCELLI, D. (2001). Construindo estratégias para vencer: um método prático, objetivo e testado para o sucesso da sua empresa. Rio de Janeiro: Campus.

VENKATRAMAN, N.; RAMANUJAM, V. (1986). Measurement of business performance in strategy research: a comparison of approaches. Academy of Management Review. New York, v. 11, n. 4 , p.801-814, Oct.

XAVIER, F. M. (2005). A formulação da estratégia de operações como fator de melhoria da competitividade no varejo. Tese de doutorado. Programa de Pós-Graduação em Engenharia de Produção da Universidade Federal de Santa Catarina. Florianópolis.

WELSH, J. A.; WHITE, J. F. (1981). A small business is not a little big business. Harvard Business Review. v. 59, n. 4, .p. 18-32, Jul. /Aug.

WILSON, C.; SHEAHAN, C. (2006). State of performance measurement practice in SMEs. NEELY, A.; KENNERLEY, M.; WALTERS, A. (Coord.). Performance Measurement and Management: public and private. London: UK, p.809-816.

WU, D. (2006). Performance measurement in SMEs: a new approach. NEELY, A; KENNERLEY, M.; WALTERS, A. (Coord.). Performance Measurement and Management: public and private. London: UK, p. 817-824.

YIN, R. K. (2005). Estudo de caso: planejamento e métodos. Porto Alegre: Bookman, 3 ed. 
ZIMAN, J. (1979). O homem e a ciência: conhecimento público. São Paulo: USP. Cap. 1 e 2, p.17-45. 


\section{APÊNDICE A - CARACTERIZAÇÃO EMPRESA E DIRIGENTE}

(1 $1^{\mathrm{a}}$ e $2^{\mathrm{a}}$ FASES $)$

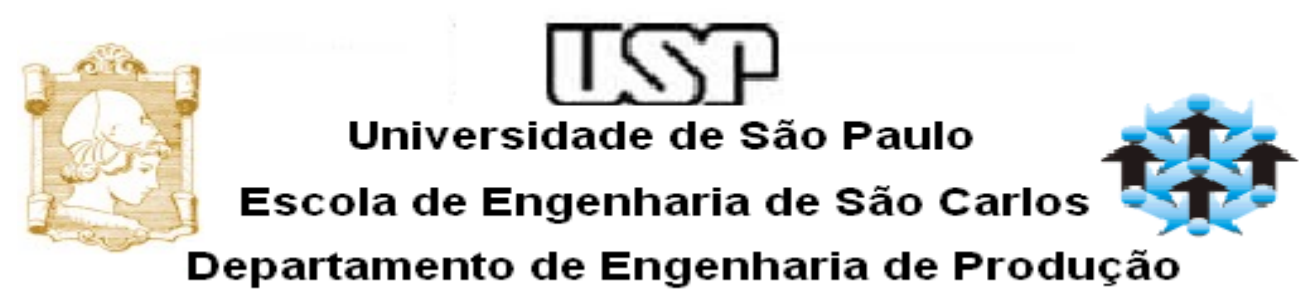

\section{Etapa 1: Caracterizacão da Empresa}

1) Empresa (Razão Social):

2) Ano de Fundação da Empresa:

3)Telefone comercial:

4) Endereço:

5) Número total de empregados:

6) Número total de UH (unidades habitacionais)

7) Os principais clientes da empresa buscam atividades de:
$\square$ Lazer/Culturais
$\square$ Negócios
Aventura
Saúde

8) Quando é o período de temporada?

9) Qual é o valor médio da diária em $\mathrm{R} \$$ ?

Durante a semana normal:

Durante o fim de semana normal:

Durante a semana de temporada:

Durante o fim de semana de temporada:

\section{Etapa 2: Identificacão do Dirigente da Empresa}

1) Nome do entrevistado(a):

2) Data de Nascimento:

3) Sexo: $\square$ Masculino

Feminino 
4) Telefone para contato:

5) E-mail:

6) É o proprietário da empresa?

$\square$ Não. Qual é seu Cargo na empresa?

$\square$ Sim. Qual função antes de abrir esta empresa?

8) Qual seu nível de escolaridade?

9) Tinha experiência anterior ou conhecimentos neste ramo de negócios da empresa?

$\square$ Sim. Qual função?

$\square$ Não

10) Qual foi a motivação para abertura da empresa?

$\square$ Oportunidade de negócio

$\square$ Já era da família

$\square$ Saída do

Emprego

$\square$ Outra (especificar): 


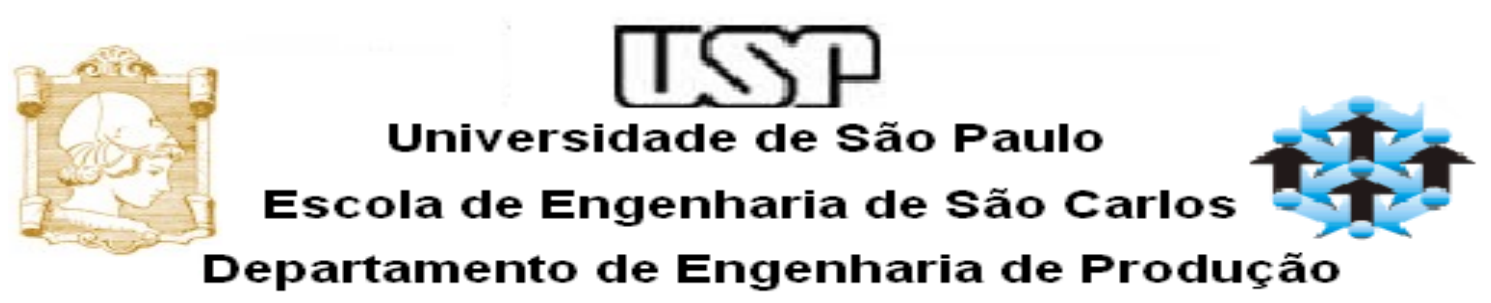

São Carlos, ệs de 2009.

Prezado Senhor (a),

Estamos realizando uma pesquisa acadêmica com o objetivo de identificar a prática e os indicadores do controle do desempenho organizacional utilizados pelas pequenas, médias e grandes empresas hoteleiras da região central do Estado de São Paulo e avaliar sua adequação aos fatores-chave de competitividade do setor.

Para atingirmos nosso objetivo estaremos realizando entrevistas para coleta dos dados necessários e solicitamos que seja respondido pelo dirigente responsável por tomar decisões sobre os futuros direcionamentos da empresa, ressaltando que a sua participação é fundamental para o sucesso da pesquisa.

Não é solicitada informação sigilosa, ainda assim as informações fornecidas serão tratadas com o sigilo necessário e utilizadas de maneira agregada, pois temos o intuito de compreender as práticas administrativas do segmento como um todo.

Assumimos o compromisso que somente o Prof $^{\circ}$ Edmundo Escrivão Filho e a aluna Gysele Lima Ricci terão acesso aos dados e nos comprometemos que os dados fornecidos durante as entrevistas serão transcritos e submetidos ao entrevistado. Somente após a aprovação do entrevistado que os dados da entrevista serão utilizados pelos pesquisadores. Informamos que os dados serão destruídos após a confecção do relatório final da pesquisa. Assumimos o compromisso de enviar um relatório com os resultados finais.

Aproveitamos o ensejo para antecipar os agradecimentos por sua valiosa colaboração.

Edmundo Escrivão Filho

Prof $^{\circ}$ do Departamento de Engenharia de Produção - EESC-USP edesfi@sc.usp.br

\section{Gysele Lima Ricci \\ Mestranda em Engenharia de Produção - EESC-USP \\ gysele@sc.usp.br / gyricci@yahoo.com.br}

De acordo,

Eu concordo em participar da pesquisa e estou informado do seu desenvolvimento. 


\section{ROTEIRO DE ENTREVISTAS - $3^{\text {a }}$ Fase}

\section{1) ESPECIFICIDADES DE GESTÃO DA PEQUENA EMPRESA}

$\checkmark$ Pessoas da família do proprietário trabalham na empresa? Quais funções exercem?

$\checkmark$ Quais são as funções do proprietário na empresa?

$\checkmark$ Quanto tempo de seu dia é gasto para pensar ou elaborar estratégias? E quanto tempo é gasto com atividades cotidianas/ operacionais?

$\checkmark$ Quanto tempo é gasto na coleta e análise de informação sobre o ambiente?

$\checkmark$ Você considera que o tempo é bem administrado?

$\checkmark$ A administração da empresa é realizada mediante instrumentos administrativos formalizados/ estruturados? Caso contrário, por quê?

2) INFLUÊNCIA DO TAMANHO DA EMPRESA NA FORMULAÇÃO DOS $\underline{\text { PROCEDIMENTOS DE GESTÃO }}$

Como é a estrutura organizacional da empresa? Quais são os cargos e funções?

$\checkmark$ As funções são determinadas para cada cargo, ou cada um faz o que é preciso fazer naquele momento?

$\checkmark$ Existem pessoas na empresa qualificadas para estas funções?

$\checkmark$ Você considera que há pessoas suficientes na empresa para desempenhar todas as funções necessárias?

$\checkmark$ Existem recursos financeiros suficientes para investir na empresa e em sua administração (infra-estrutura, capital de giro, contratação de pessoal qualificado, aquisição de computadores e softwares, investimento em cursos, treinamentos e livros, contratação de assessoria externa)?

\section{3) GESTÃO ESTRATÉGICA NA PEQUENA EMPRESA}

$\checkmark$ Quem participa do planejamento estratégico?

$\checkmark$ As pessoas participantes foram treinadas para isso?

$\checkmark$ As decisões mais importantes tomadas até hoje foram para resolver problemas detectados internamente ou advindos do mercado?

$\checkmark$ Todas estratégicas seguidas pela empresa foram decisões tomadas pela alta cúpula e trazidas à tona pela alta cúpula ou teve insigths e participações de outros membros da organização que não os "diretores"? 
Em que percentual a empresa pode classificar as suas ações como planejadas versus as ações que emergiram ao longo do processo de evolução da empresa?

$\checkmark$ Quais são os mecanismos utilizados pela empresa para buscar a eficiência e eficácia nas suas ações?

$\checkmark$ Existem mecanismos estimuladores de estratégias emergentes? Exemplos?

$\checkmark$ Fazem-se alguma pesquisa para conhecer o que clientes procuram?

\section{4) CONTROLE E MEDIÇÃO DE DESEMPENHO ORGANIZACIONAL NA}

\section{PEQUENA EMPRESA}

$\checkmark$ A organização tem controle eficaz organizacional? Ele é aplicado em todos os níveis organizacionais?

$\checkmark$ Usa o controle para garantir o alcance eficaz e eficiente da missão e objetivos organizacionais?

$\checkmark$ Os dirigentes/proprietários estão envolvidos com as atividades de controle?

$\checkmark$ Que tipo de controle é exercido na organização?

- de mercado (utiliza critérios e mecanismos de mercado como preços, lucros, etc. para avaliar as atividades e resultados organizacionais)

- burocrático (autoridade e responsabilidade hierárquicas)

- de clã (compartilhamento de normas, crenças, expectativas, etc. relevantes da cultura organizacional - confia nos relacionamentos informais para alcançar os objetivos organizacionais)

$\checkmark$ A organização toma medidas corretivas quando ocorrem desvios?

$\checkmark$ Todos envolvidos com a empresa têm consciência do nível de desempenho esperado para dada tarefa organizacional?

$\checkmark$ A organização avalia seu progresso em direção aos seus objetivos?

$\checkmark$ A organização usa medidas de desempenho para direcionar as ações de melhoria que são implementadas?

$\checkmark$ As medidas de desempenho são baseadas nas expectativas dos clientes?

$\checkmark$ A medição de desempenho visa contribuir para a efetivação da estratégia? Ela é um veículo visibilizador da estratégia?

$\checkmark$ A organização usa algum modelo de medição de desempenho?

\section{5) INDICADORES DE MEDIÇÃO DE DESEMPENHO}

$\checkmark$ A organização utiliza algum indicador para avaliar seu desempenho no 
mercado?

$\checkmark$ A organização prioriza algum indicador como participação de mercado, volume de vendas, satisfação do cliente, a imagem institucional perante as diversas partes interessadas, seu índice de rentabilidade ou produtividade?

$\checkmark$ A melhoria do clima organizacional (satisfação dos funcionários) influencia a satisfação dos clientes, que por sua vez afeta o nível de vendas?

\section{6) AS ESPECIFICIDADES DO SETOR DE SERVIÇOS, ESPECIALMENTE DA} HOTELARIA, INFLUENTES NA GESTÃO EMPRESARIAL.

$\checkmark$ O ambiente de competição da empresa é complexo, dinâmico? Quem dita a complexidade e a dinâmica: O Mercado? A tecnologia? Ambos?

$\checkmark$ Como você percebe a concorrência da sua empresa com outras maiores do mesmo setor? Você acha que as condições são as mesmas? Quais vantagens e desvantagens você acredita que sua empresa tem frente às concorrentes maiores?

$\checkmark$ Como você avalia o poder de barganha dos seus fornecedores? Isto prejudica a gestão e o desempenho da empresa?

$\checkmark$ Como você percebe a influência sobre a gestão e o desempenho da empresa das forças do macro-ambiente (econômicas, sociais, legais, políticas, ecológicas e tecnológicas)? De que maneira essa influência se manifesta?

$\checkmark$ Existem algumas destas variáveis que a empresa consegue influenciar/controlar? Como adquirir força perante o contexto?

$\checkmark$ Em qual momento o mercado hoteleiro da cidade e região se encontra:

- crescimento: crescentes ocupações e valorização das diárias

- declínio/contração: há um declínio nas ocupações, apesar do valor das diárias permanecerem estável

- recuperação: já se percebe um crescimento nas ocupações e na recuperação do valor das diárias

- ápice: as ocupações e o valor das diárias estabilizam em patamares elevados -depressão: menores ocupações e redução do valor das diárias, eventualmente descontos, promoções ou mesmo acirramento da concorrência

$\checkmark$ Qual o perfil dos hóspedes do Hotel?

- Hóspedes sem negociação prévia ou reserva 
- Hóspedes com negociação prévia ou reserva

- Hóspedes com pacote turístico

- Hóspedes em viagens empresariais

Existem tarifas de hospedagem diferenciadas para cada perfil? ( ) Sim ( ) Não Em caso afirmativo, cite os valores em reais

$\checkmark$ Como a demanda (procura) por serviços hoteleiros da região pode ser considerada:

- muito competitivo

- competitivo

- pouco competitivo

$\checkmark$ Qual o tipo de meio de hospedagem que de sua empresa compete:

- hotéis e pousadas da cidade

- hotéis e pousadas da cidade e da região

- hotéis e pousadas de todo o estado de São Paulo

- hotéis e pousadas de outras regiões do Brasil 


\section{Apêndice C - Protocolo da pesquisa (cont.)}

Objetivo Geral: Avaliar a existência de uma orientação do controle organizacional nas pequenas e médias empresas hoteleiras e sua adequação aos fatoreschave de competitividade do setor

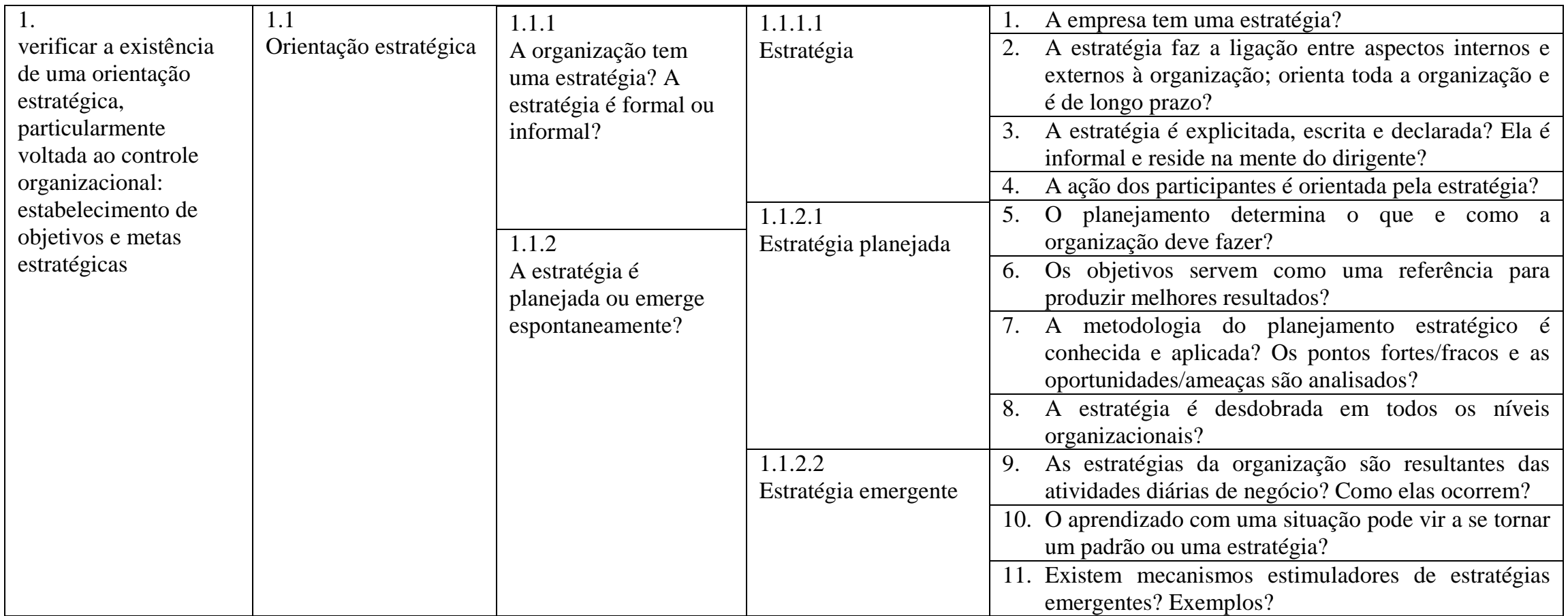




\section{Apêndice C - Protocolo da pesquisa (cont.)}

\begin{tabular}{|c|c|c|c|c|}
\hline Objetivos Específicos & Variáveis da Pesquisa & Questões da Pesquisa & Conceitos Relevantes & Questões do Roteiro de Entrevista \\
\hline \multirow{12}{*}{$\begin{array}{l}2 . \\
\text { Verificar a existência } \\
\text { do princípio e a prática } \\
\text { do controle } \\
\text { organizacional e o } \\
\text { estabelecimento de } \\
\text { indicadores para a } \\
\text { medição do } \\
\text { desempenho } \\
\text { organizacional }\end{array}$} & \multirow{12}{*}{$\begin{array}{l}2.1 . \\
\text { Controle } \\
\text { Organizacional }\end{array}$} & \multirow{12}{*}{$\begin{array}{l}2.1 .1 \\
\text { A organização faz o } \\
\text { controle } \\
\text { organizacional? }\end{array}$} & \multirow[t]{5}{*}{$\begin{array}{l}2.1 .1 .1 \\
\text { Controle }\end{array}$} & $\begin{array}{l}\text { 12. Existe a preocupação com o controle na } \\
\text { organização? }\end{array}$ \\
\hline & & & & $\begin{array}{l}\text { 13. Os objetivos estratégicos são desdobrados em todos } \\
\text { os níveis organizacionais? }\end{array}$ \\
\hline & & & & $\begin{array}{l}\text { 14. As metas estratégicas são transformadas em padrões } \\
\text { de controle? }\end{array}$ \\
\hline & & & & $\begin{array}{l}\text { 15. A organização monitora seu progresso em direção } \\
\text { aos objetivos estabelecidos? }\end{array}$ \\
\hline & & & & $\begin{array}{l}\text { 16. Existe alguma gratificação ou participação por } \\
\text { resultados como uma maneira de motivar o } \\
\text { funcionário? }\end{array}$ \\
\hline & & & $\begin{array}{l}2.1 .1 .2 \\
\text { Desempenho }\end{array}$ & $\begin{array}{l}\text { 17. A organização acompanha e avalia o desempenho } \\
\text { das pessoas, grupos e da própria organização? }\end{array}$ \\
\hline & & & \multirow{3}{*}{$\begin{array}{l}2.1 .1 .3 \\
\text { Medição de } \\
\text { desempenho }\end{array}$} & $\begin{array}{l}\text { 18. A organização usa medidas (padrões) para avaliar o } \\
\text { desempenho? }\end{array}$ \\
\hline & & & & $\begin{array}{l}\text { 19. As medidas de desempenho estão de acordo com as } \\
\text { metas estratégicas? }\end{array}$ \\
\hline & & & & $\begin{array}{l}\text { 20. A organização utiliza algum modelo de medição de } \\
\text { desempenho? }\end{array}$ \\
\hline & & & $\begin{array}{l}\text { 2.1.1.4 } \\
\text { Indicadores de } \\
\text { medição }\end{array}$ & $\begin{array}{l}\text { 21. Quais os principais indicadores de desempenho } \\
\text { adotados pela organização? }\end{array}$ \\
\hline & & & desempenho & $\begin{array}{l}\text { 22. Os indicadores são congruentes com os objetivos e } \\
\text { metas estratégicas? }\end{array}$ \\
\hline & & & & $\begin{array}{l}\text { 23. Os indicadores são congruentes com os requisitos de } \\
\text { competitividade do setor hoteleiro? }\end{array}$ \\
\hline
\end{tabular}




\section{Apêndice C - Protocolo da pesquisa (cont.)}

\begin{tabular}{|c|c|c|c|c|}
\hline Objetivos Específicos & Variáveis da Pesquisa & Questões da Pesquisa & Conceitos Relevantes & Questões do Roteiro de Entrevista \\
\hline \multirow{12}{*}{$\begin{array}{l}3 . \\
\text { Analisar a influência } \\
\text { das especificidades de } \\
\text { gestão das pequenas e } \\
\text { médias empresas no } \\
\text { controle } \\
\text { organizacional }\end{array}$} & \multirow{12}{*}{$\begin{array}{l}3.1 . \\
\text { Especificidades de } \\
\text { gestão das PMEs }\end{array}$} & \multirow{7}{*}{$\begin{array}{l}3.1 .1 \\
\text { Quais são as } \\
\text { especificidades de } \\
\text { gestão das PMEs? }\end{array}$} & \multirow{2}{*}{$\begin{array}{l}\text { 3.1.1.1 } \\
\text { Dimensão dirigente }\end{array}$} & 24. Quais foram às razões para iniciar o negócio? \\
\hline & & & & $\begin{array}{l}\text { 25. A gestão do proprietário-dirigente influencia no } \\
\text { alcance controle organizacional? }\end{array}$ \\
\hline & & & \multirow[t]{2}{*}{$\begin{array}{l}\text { 3.1.1.2 } \\
\text { Dimensão organização }\end{array}$} & $\begin{array}{l}\text { 26. Quais são as especificidades de gestão da } \\
\text { organização? }\end{array}$ \\
\hline & & & & $\begin{array}{l}\text { 27. As especificidades da organização estão } \\
\text { relacionadas com os objetivos organizacionais? }\end{array}$ \\
\hline & & & \multirow[t]{3}{*}{$\begin{array}{l}3.1 .1 .3 \\
\text { Dimensão contexto }\end{array}$} & $\begin{array}{l}\text { 28. O ambiente impõe barreiras para o alcance efetivo } \\
\text { do controle organizacional? }\end{array}$ \\
\hline & & & & $\begin{array}{l}\text { 29. Você acredita que as pequenas empresas competem } \\
\text { com as grandes organizações? Ser grande é ser } \\
\text { melhor? }\end{array}$ \\
\hline & & & & $\begin{array}{l}\text { 30. Quais forças que determinam a natureza e o grau de } \\
\text { concorrência dentro de uma organização? }\end{array}$ \\
\hline & & \multirow{5}{*}{$\begin{array}{l}3.1 .2 . \\
\text { As especificidades de } \\
\text { gestão das PMEs } \\
\text { influenciam a prática } \\
\text { do controle } \\
\text { organizacional? }\end{array}$} & \multirow{5}{*}{$\begin{array}{l}3.1 .2 .1 \\
\text { Prática do controle } \\
\text { organizacional nas } \\
\text { PMEs }\end{array}$} & $\begin{array}{l}\text { 31. As especificidades da organização influenciam na } \\
\text { prática do controle organizacional? }\end{array}$ \\
\hline & & & & $\begin{array}{l}\text { 32. Como a organização mantém o controle para o } \\
\text { alcance efetivo de seus objetivos? }\end{array}$ \\
\hline & & & & $\begin{array}{l}\text { 33. Os objetivos da organização são transmitidos a } \\
\text { todos envolvidos? }\end{array}$ \\
\hline & & & & $\begin{array}{l}\text { 34. Existem características das PMES que servem como } \\
\text { obstáculo para o alcance do controle } \\
\text { organizacional? }\end{array}$ \\
\hline & & & & $\begin{array}{l}\text { 35. As PMEs usam princípios de administração } \\
\text { semelhantes às grandes organizações? }\end{array}$ \\
\hline
\end{tabular}




\section{Apêndice C - Protocolo da pesquisa (cont.)}

\begin{tabular}{|c|c|c|c|c|}
\hline Objetivos Específicos & Variáveis da Pesquisa & Questões da Pesquisa & Conceitos Relevantes & Questões do Roteiro de Entrevista \\
\hline \multirow{11}{*}{$\begin{array}{l}4 . \\
\text { Discutir a validade dos } \\
\text { indicadores de } \\
\text { medição de } \\
\text { desempenho das } \\
\text { grandes empresas para } \\
\text { inferir os fatores- } \\
\text { críticos de sucesso do } \\
\text { setor hoteleiro da } \\
\text { região }\end{array}$} & \multirow{11}{*}{$\begin{array}{l}4.1 . \\
\text { Fatores-críticos de } \\
\text { sucesso do setor } \\
\text { hoteleiro na região } \\
\text { (inferidos criticamente } \\
\text { dos indicadores de } \\
\text { desempenho das } \\
\text { grandes organizações) }\end{array}$} & \multirow{11}{*}{$\begin{array}{l}4.1 .1 \\
\text { Os fatores-críticos de } \\
\text { sucesso do setor } \\
\text { hoteleiro da região } \\
\text { podem ser inferidos } \\
\text { dos indicadores de } \\
\text { desempenho das } \\
\text { grandes organizações }\end{array}$} & \multirow{11}{*}{$\begin{array}{l}4.1 .1 .1 \\
\text { Indicadores de } \\
\text { medição de } \\
\text { desempenho }\end{array}$} & $\begin{array}{l}\text { 36. É possível identificar os fatores-criticos de sucesso } \\
\text { da hotelaria em geral? }\end{array}$ \\
\hline & & & & $\begin{array}{l}\text { 37. Existem fatores-críticos de sucesso por segmento da } \\
\text { hotelaria? }\end{array}$ \\
\hline & & & & $\begin{array}{l}\text { 38. Quais são os fatores-críticos de sucesso específicos } \\
\text { do setor hoteleiro da região? }\end{array}$ \\
\hline & & & & $\begin{array}{l}\text { 39. Os indicadores de medição de desempenho do hotel } \\
\text { são congruentes com os fatores-críticos de sucesso } \\
\text { do setor hoteleiro da região? }\end{array}$ \\
\hline & & & & $\begin{array}{l}\text { 40. Os grandes hotéis da região ditam os fatores-críticos } \\
\text { de sucesso do setor hoteleiro da região? }\end{array}$ \\
\hline & & & & $\begin{array}{l}\text { 41. Os indicadores das grandes empresas hoteleiras } \\
\text { possibilitam o estabelecimento de metas } \\
\text { quantificáveis? }\end{array}$ \\
\hline & & & & $\begin{array}{l}\text { 42. Quais características do setor hoteleiro influenciam } \\
\text { na escolha dos indicadores do controle } \\
\text { organizacional das grandes empresas hoteleiras? }\end{array}$ \\
\hline & & & & $\begin{array}{l}\text { 43. As práticas de medição de desempenho das grandes } \\
\text { organizações diferem das PMEs? }\end{array}$ \\
\hline & & & & $\begin{array}{l}\text { 44. Os fatores-chaves de competitividade são } \\
\text { compatíveis com os indicadores de medição de } \\
\text { desempenho? }\end{array}$ \\
\hline & & & & $\begin{array}{l}\text { 45. Quais indicadores utilizados pelas grandes empresas } \\
\text { diferem das PMES hoteleiras? }\end{array}$ \\
\hline & & & & $\begin{array}{l}\text { 46. Os indicadores das grandes empresas hoteleiras são } \\
\text { viáveis nas PMES hoteleiras? }\end{array}$ \\
\hline
\end{tabular}




\section{APÊNDICE D - LISTA DAS EMPRESAS MAPEADAS}

\section{$1^{\text {a }}$ FASE}

\begin{tabular}{|c|c|c|c|c|c|c|}
\hline Águas de São Pedro & & & & & & \\
\hline Hotel & Fundação & Funcionários & UH's & Segmento Turístico & Endereço & Telefone \\
\hline Avenida Charme Hotel/ COLINA V. & 1943 & 20 & 58 & lazer & Av. Carlos Mauro, 246. & (19) 34827900 \\
\hline Flat Ônix Residence & 1996 & $7+2$ & $48 / 13$ & Lazer e Saúde & R. Armando Brandini, 166. & (19) 34821730 \\
\hline Grande Hotel São Pedro & 1940 & 215 & 112 & lazer/eventos & $\begin{array}{l}\text { Pq. Dr. Octávio de Moura Andrade } \\
\mathrm{s} / \mathrm{n} \text {. }\end{array}$ & (19) 34821211 \\
\hline LS Hotel & 2005 & 9 & 20 & lazer & R. Antonio Albino Ribeiro, 153. & (19) 34827474 \\
\hline Hotel Bandeirantes & 1942 & & 15 & lazer & R. Joviano Nouer, 237. & (19) 34821228 \\
\hline Hotel Chalé Estância das Flores & 1979 & 3 & 20 & Lazer e Saúde & R. dos Lírios, 471. & (19) 34823000 \\
\hline Hotel Estância & & 9 & 43 & lazer & R. Patrício Miguel Carreta, 26. & (19) 34821182 \\
\hline Hotel Jerubiaçaba & 1965 & 70 & 125 & Lazer e Saúde/ Negócios & Av. Carlos Mauro, 168. & (19) 34821411 \\
\hline Hotel Líder & 1969 & 2 & 8 & lazer & R. Egydio Piccoli, 82. & (19) 34821266 \\
\hline Hotel Portal das Águas & 17 anos & 18 & 38 & lazer & R. Maximiano Santin, 120. & (19) 34821259 \\
\hline Hotel Santo Antonio & 1949 & $6+3$ & 25 & lazer & R. Antonio Feijó, 130. & (19) 34821924 \\
\hline Hotel Susy & $\mathrm{n}$ atende & & & & R. Maximiano Santin, 37. & \\
\hline Hotel Villa & $\mathrm{n}$ atende & & 26 & & R. Joviano Nouer, 155. & (19) 34821250 \\
\hline Piccola Pousada & 1997 & 1 & 9 & lazer & R. Egydio Piccoli, 69. & (19) 34821973 \\
\hline Pousada Águas de São Pedro & 2006 & 1 & 16 & Lazer e Saúde/ Negócios & R. João Batista Azevedo, 204. & (19) 34821253 \\
\hline Pousada Boni & 2006 & 2 & 8 & lazer & R. das Primaveras, 115. & (19) 31811122 \\
\hline Pousada Bons Caminhos & 1999 & $2+2$ & & lazer & R. Veríssimo Prado, 1300. & (19) 34812600 \\
\hline Pousada Estrela da Manhã & 2001 & 1 & 7 & Lazer & R. Guiomar Soares de Andrade, 25. & (19) 34822140 \\
\hline Pousada Mineiro Noronha & & & 15 & lazer & R. Raul Ribeiro da Costa, 114. & (19) 34821179 \\
\hline Posada Nossa Senhora Aparecida & 1972 & $6+3$ & 25 & Lazer e Saúde/ Negócios & Praça da Matriz, 25. & (19) 34821280 \\
\hline Solar La Luna & 2004 & 5 & 8 & lazer & R. das Violetas, 170. & (19)31811111 \\
\hline
\end{tabular}




\begin{tabular}{|c|c|c|c|c|c|c|}
\hline \multicolumn{7}{|l|}{ Analândia } \\
\hline Chalé Macaúva & & & 4 & lazer & R. $\mathrm{H}, 61$. & (11) 81246979 \\
\hline Alto da Boa Vista Hotel & & $3+1$ & 10 & lazer & Av. Oito, 555. & (19) 35661320 \\
\hline Hotel Estância Sopro do Vento & & & 12 & lazer & R. Três, 1100. & (19) 35667115 \\
\hline Pousada da Carola & & & 10 & lazer & R. Três, 732. & (19) 35661560 \\
\hline Pousada do Fotógrafo & & & 2 & lazer/rural & Estrada Municipal, 351. & (19) 35270294 \\
\hline Pousada Inglesa & & & 4 & lazer & Rod. SP 225 Km 65,7 & (19) 35667287 \\
\hline Pousada Recanto Som das Águas & & & 8 & lazer & Travessa Marginal, 1. & (19) 35413550 \\
\hline Pousada Refúgio do Vale & & & 4 & lazer & R. Três, 891. & (19) 35661234 \\
\hline Pousada Vale da Lua & & & 6 & lazer & R. Três, 1430. & (19) 35661112 \\
\hline \multicolumn{7}{|l|}{ Brotas } \\
\hline Hotel & Fundação & Funcionários & UH's & Segmento Turístico & Endereço & Telefone \\
\hline Areia que Canta Fazenda Hotel & 1999 & 10 & 50 & lazer/ecoturismo & $\begin{array}{l}\text { Rod. Eng. Paulo Nilo Romano Km } \\
124,5 .\end{array}$ & (14) 36531382 \\
\hline Casarão Hotel & & 10 & 35 & lazer & Av. Mário Pinotti, 1057. & (14) 6531438 \\
\hline Espaço do Pouso & & & 5 & lazer & $\begin{array}{l}\text { R. Edelgonda Martinelli Sgorgon, } \\
220 .\end{array}$ & (14) 6531406 \\
\hline Estalagem Quinta das Cachoeiras & 1999 & 5 & 14 & lazer & R. João Rebecca, 225. & (14) 6532497 \\
\hline Brotas Eco Resort & & 80 & 37 & lazer/rural/negócios & Chácara Coimbra, s/n. & (11) 30351900 \\
\hline Fazenda Hotel Vale Verde & & 9 & 20 & lazer/rural & Rod. Torrinha São Pedro Km 10. & (14) 36566089 \\
\hline Hotel Mosteiro São Francisco de Assis & 2007 & 12 temp. & 17 & lazer & $\begin{array}{l}\text { Estrada Municipal Brotas- } \\
\text { Patrimônio Km 10,5 }\end{array}$ & (14) 36531064 \\
\hline Hotel Pousada Alvorada & 1979 & 10 & 40 & lazer/aventura & Av. Mário Pinotti, 1181. & (14) 36531027 \\
\hline Hotel Pousada Natural Canto do Sol & 2002 & $4+2$ & 22 & lazer & $\begin{array}{l}\text { Av. Lourival Jaubert da Silva Braga, } \\
1750 .\end{array}$ & (14) 36538081 \\
\hline Hotel Vivenda das Cachoeiras & 2001 & $4+3$ & 24 & lazer & Av. Lourival J. da Silva Braga 1130. & (14) 36535638 \\
\hline Mirágua Refúgios Pousada & 2003 & 3 & 16 & lazer & Av. Rodolpho Guim, 94. & (14) 36538085 \\
\hline Pousada Alto da Boa Vista & 1999 & 3 & 15 & lazer & R. Luis A. T.Cunha, 975. & (14) 36535635 \\
\hline Pousada Broto D’Água & 2001 & 5 & 20 & lazer & $\begin{array}{l}\text { Av. Lourival Jaubert da Silva Braga, } \\
1466 .\end{array}$ & (14) 36535003 \\
\hline Pousada Cachoeira Escorregador & & & 7 & lazer & & (14) 97784322 \\
\hline
\end{tabular}




\begin{tabular}{|c|c|c|c|c|c|c|}
\hline Pousada Cochilo & 2000 & 2 & 8 & lazer & R. Jaú, s/n. & (14) 36531124 \\
\hline Pousada Caminho das Águas & & 5 & 18 & lazer & Av. Mário Pinotti, 1110. & (14) 6532428 \\
\hline Pousada das Araras & & 4 & 17 & lazer & R. Samuel Guerreiro, 110. & (14) 36538032 \\
\hline Pousada das Nascentes & & 9 & 18 & lazer & R. Antonio Mariano do Prado, 260. & (14) 36536133 \\
\hline Pousada do Aconchego & 2004 & 2 & 11 & lazer & R. João Cassaro, 225. & (14) 36531099 \\
\hline Pousada do Lago & 2000 & 6 & 16 & lazer/negócios & $\begin{array}{l}\text { Av. Lourival Jaubert da Silva Braga, } \\
2180 .\end{array}$ & (14) 36535797 \\
\hline Pousada do Sol & 1998 & $7+2$ & 25 & lazer & Av. Mário Pinotti, 1400. & (14) 36532016 \\
\hline Pousada Frangipani & 2007 & 10 & 22 & lazer & $\begin{array}{l}\text { Estrada Municipal Brotas- } \\
\text { Patrimônio Km } 8 .\end{array}$ & (14) 36534851 \\
\hline Pousada Jacaré Pepira & 2000 & 2 & 7 & lazer & R. Joaquim Dias Ramos, 75. & (14) 36536152 \\
\hline Pousada Jacaúna & & 5 & 17 & lazer & $\begin{array}{l}\text { Av. Pedro Saturnino de Oliveira, } \\
\mathrm{s} / \mathrm{n} \text {. }\end{array}$ & (14) 36538061 \\
\hline Pousada Kampai & 2004 & 2 & 10 & lazer & $\begin{array}{l}\text { Estrada Municipal Brotas- } \\
\text { Patrimônio Km } 2 .\end{array}$ & (14) 36532832 \\
\hline Pousada Recanto Alvorada & não quer & 12 & 22 & lazer & Rod. SP 197 Km 13. & (14) 36566332 \\
\hline Pousada Recanto dos Saltos & & & 5 & lazer & Av. Mario Pinotti, 113. & (14) 36538000 \\
\hline Pousada Recanto dos Pássaros & 2002 & 3 & 9 & lazer & R. Eliseu Lourenção, 428. & (14) 36531223 \\
\hline Pousada Sabiá & 12 anos & 6 & 15 & lazer & Rod. SP 225 Km 131,5. & (14) 36531582 \\
\hline Pousada Trovão das Águas & $\mathrm{n}$ atende & & & lazer & R. Marino Osti, 345. & \\
\hline Primavera da Serra & 1999 & 6 & 15 & lazer & Rodovia SP km 225 & (14) 36532775 \\
\hline Sítio Roda D’Água & 2001 & 6 & 6 & lazer/rural & R. Dr. Guena, 80. & (14) 36534366 \\
\hline Villa do Conde Hospedagem & & & 5 & lazer & Av. Mário Pinotti, 640. & (14) 36531133 \\
\hline Fazenda Sinhá Ruth & & só temp. & 3 & lazer/rural & & (11) 99071120 \\
\hline Hotel Faz. Haras Recanto Shangrila & 1997 & 3 & 10 & lazer/rural & Fazenda Haras s/n & (14)36532371 \\
\hline \multicolumn{7}{|l|}{ Charqueada } \\
\hline Hotel & Fundação & Funcionários & UH's & Segmento Turístico & Endereço & Telefone \\
\hline Águas de Santa Júlia Hotel & 1997 & 8 & 8 & lazer & Rod. SP 308 Km 192. & (19) 34862065 \\
\hline Hotel Fazenda Casa Pedra Estância & 1998 & nenhum & 25 & lazer/rural & Rod. SP 308 Km 184. & (19) 34251892 \\
\hline Hotel Toscana & 1969 & 3 & $4+20$ & lazer & R. 1 de Maio, 71. & (19) 34861145 \\
\hline Corumbataí & & & & & & \\
\hline
\end{tabular}




\begin{tabular}{|c|c|c|c|c|c|c|}
\hline Hotel & Fundação & Funcionários & UH's & Segmento Turístico & Endereço & Telefone \\
\hline \multicolumn{7}{|l|}{ NÃO HÁ MEIOS DE HOSPEDAGEM } \\
\hline \multicolumn{7}{|l|}{ Ipeúna } \\
\hline Hotel & Fundação & Funcionários & UH's & Segmento Turístico & Endereço & Telefone \\
\hline Hotel Country Club & & 5 & 20 & lazer & Estrada do Recanto & (19) 35761352 \\
\hline Pousada da Serra & 2009 & 4 & 16 & lazer/rural & Sitio ão Joao & (19)3534 7124 \\
\hline \multicolumn{7}{|l|}{ Itirapina } \\
\hline Hotel & Fundação & Funcionários & UH's & Segmento Turístico & Endereço & Telefone \\
\hline Pousada do Clube de Campo do Broa & & $22+8$ & 63 & lazer/aventura & Rod. Ayrton Senna Km 8. & (19) 38489292 \\
\hline Hotel Harmonia & & 4 & 11 & lazer & & \\
\hline Pousada Ubar & & 2 & 4 & lazer & & \\
\hline Paraiso das Aguas & & $20+5$ & 40 & lazer/aventura & Av. 4 & (19) 35751257 \\
\hline \multicolumn{7}{|l|}{ Piracaia } \\
\hline \multicolumn{7}{|l|}{ NÃO HÁ MEIOS DE HOSPEDAGEM } \\
\hline \multicolumn{7}{|l|}{ Rio Claro } \\
\hline Hotel & Fundação & Funcionários & UH's & Segmento Turístico & Endereço & Telefone \\
\hline Central Park Apart Hotel & 1999 & 20 & 98 & negócios & Av. Um, 1030. & (19) 35224242 \\
\hline Hotel Cristal & 2003 & 20 & 60 & negócios & Av. Tancredo Neve, 1440. & (19) 35333155 \\
\hline Hotel Central Rioclarense & 21 anos & 2 & 19 & lazer & Av. Três, 615. & (19) 35340945 \\
\hline Hotel D' Itália & 14 anos & 6 & 28 & lazer & R. Dois, 1760. & (19) 35237471 \\
\hline Hotel dos Reis & $\mathrm{n}$ telefone & & & & Av. Dois, 735. & \\
\hline Hotel Estação & 1910 & $2+1$ & 34 & lazer & R. Um, 1069. & (19) 35341033 \\
\hline Hotel Fazenda Harmonia & $\mathrm{n}$ telefone & & & & Rod. Washigton Luiz Km 176. & \\
\hline Hotel Panorama & $\mathrm{n}$ telefone & & & & Sítio São João, 27. & \\
\hline Hotel Pousada do Barão & & 4 & 27 & lazer & Rod. Washigton Luiz Km 177. & (19) 35346804 \\
\hline Hotel Rio Claro & & 6 & 28 & lazer & Av. cinco, 143 & (19) 35243183 \\
\hline Hotel Santo Antônio & & 9 & 36 & lazer & R. Cinco, 1067. & (19) 35243563 \\
\hline
\end{tabular}




\begin{tabular}{|c|c|c|c|c|c|c|}
\hline Hotel Stein & & 6 & 32 & lazer & R. Quatro, 1463. & (19) 35242009 \\
\hline Hotel Tertulio's & 12 anos & 6 & 38 & lazer & Av. Oitenta e Oito, 161. & (19) 35270149 \\
\hline Hotel Zarkos & 1983 & 18 & 88 & lazer & Rod. SP 191 Km 68. & \\
\hline Itaipu Hotel & & 7 & 33 & lazer & R. Três, 1605. & (19) 35244955 \\
\hline Líder Hotel & & 21 & 63 & lazer/negócios & Av. Dois, 198. & 08007715655 \\
\hline Rio Claro Plaza Hotel & & 20 & 62 & negócios & Rod. Washigton Luiz Km 174. & (19) 35262100 \\
\hline \multicolumn{7}{|l|}{ Santo Cruz da Conceição } \\
\hline $\begin{array}{r}\text { Hotel } \\
\end{array}$ & Fundação & Funcionários & UH's & Segmento Turístico & Endereço & Telefone \\
\hline Estância Vale Nobre & 1997 & 4 & 14 & lazer/rural & Av. Rodolfo Moreli, s/n & (19) 35721421 \\
\hline Hotel Santa Cruz da Conceição & & & & lazer & R. Major Arouca, 253. & (19) 35671225 \\
\hline \multicolumn{7}{|l|}{ Santa Maria da Serra } \\
\hline Hotel & Fundação & Funcionários & UH's & Segmento Turístico & Endereço & Telefone \\
\hline Pousada Colina dos Pescadores & 2004 & 8 & 8 & lazer & $\begin{array}{c}\text { Rodovia Geraldo Pereira de } \\
\text { Barros,km151 }\end{array}$ & $19-34877284$ \\
\hline \multicolumn{7}{|l|}{ São Carlos } \\
\hline Hotel & Fundação & Funcionários & UH's & Segmento Turístico & Endereço & Telefone \\
\hline Arco Hotel & 2008 & 20 & 96 & negócios/lazer & Av. Getúlio Vargas, 1250. & (16) 33687070 \\
\hline Hotel Accácio & 1927 & 10 & 45 & lazer & Av. São Carlos, 1981. & (16) 33749216 \\
\hline Hotel Atobá & 1990 & 14 & 35 & negócios/lazer & Av. São Carlos, 3163. & (16) 33743252 \\
\hline Hotel Caiçara & 1976 & 18 & 60 & negócios/lazer & R. Conde do Pinhal, 2217. & (16) 33715133 \\
\hline Hotel Graúnas & 1993 & 12 & 59 & lazer & R. José Saia, 129. & (16) 3368-3242 \\
\hline Hotel Íbis São Carlos & 2001 & 22 & 112 & lazer/negócios & R. Passeio dos Ypês, 140. & (16) 21066500 \\
\hline Hotel Malibú & 1979 & 12 & 40 & lazer & R. General Osório, 542. & (16) 33721211 \\
\hline Hotel Marques & 1905 & 7 & 55 & lazer & R. General Osório, 480. & (16) 33740313 \\
\hline Hotel Paulista & & & & lazer & Praça Antonio prado, 7. & \\
\hline Hotel Toscano & 1908 & 10 & 90 & lazer & R. Aquidaban, 76 . & (16) 33717373 \\
\hline Hotel Ypê & 1977 & 4 & 14 & lazer & Av. Carlos Botelho, 2060 & (16) 33710026 \\
\hline
\end{tabular}




\begin{tabular}{|c|c|c|c|c|c|c|}
\hline Indaiá Hotel & 1991 & 7 & 19 & negócios/lazer & R. Jacinto Favoreto, 351. & (16) 33719122 \\
\hline Indaiá Hotel Residence & 2000 & 15 & 32 & lazer/negócios & R. Facinto Favoreto, 782. & (16) 33727511 \\
\hline Perea Hotel & 1997 & 20 & 76 & lazer & Av. Araraquara, 329. & 16) $3361-1149$ \\
\hline Pousada Conde do Pinhal & 1976 & 8 & 20 & lazer & Washington Luiz Km 222. & (16) 21060800 \\
\hline Quality Hotel Anacã & 1987 & 50 & 83 & negócios & Av. São Carlos, 2690. & (16) 33734000 \\
\hline San Ciro Apart Hotel & 2002 & 9 & 18 & lazer & R. 28 de setembro, 2222 & (16) 33721213 \\
\hline \multicolumn{7}{|l|}{ São Pedro } \\
\hline Hotel & Fundação & Funcionários & UH's & Segmento Turístico & Endereço & Telefone \\
\hline A Villa Normanda Pousada & & 15 & 40 & lazer & $\begin{array}{l}\text { Av. das Tulipas, Lotes } 8 \text { e } 9 \text { Quadra } \\
55 .\end{array}$ & (19) 34831311 \\
\hline Arca Pousada & 1996 & 2 & 20 & lazer & Rod. SP 304 Km 196. & (19) 34811940 \\
\hline Castelinho Pesca e Lazer & 1986 & & 3 & lazer/rural & Rod. SP 304 Km 195. & (19) 34813447 \\
\hline Chalé da Serra & 1998 & & 7 & lazer & Rod. Ulisses Guimarães Km 15. & (11) 37410824 \\
\hline Gruta dos Anões & & 6 & 7 & lazer & Estrada Água Mineral, Km 2. & (19) 34812922 \\
\hline Hotel Cascata Dorigon & 1990 & 5 & 18 & lazer & R. Veríssimo Prado, 1028. & (19) 34811047 \\
\hline Hotel Central & & & 12 & lazer & Praça Gustavo Teixeira, 692. & (19) 34811670 \\
\hline Hotel Fazenda Colina Verde & 1978 & 180 & 155 & lazer/negócios/rural & R. Veríssimo Prado, 1500. & (19) 34819999 \\
\hline Hotel Fazenda São João & 1978 & $90+15$ & 113 & lazer/negócios/rural & Av. Paschoal Antonelli, 800. & (19) 34839000 \\
\hline Hotel Imigrantes & 2007 & 3 & 30 & lazer & Av. dos Imigrantes, 1010. & (19)34831863 \\
\hline Hotel Paraíso dos Alpes & 1999 & & 18 & lazer & Av. das Azaléias, 11 Quadra 6. & (19) 34812797 \\
\hline Hotel Paraty & ligar & & 16 & lazer & R. Victor Santo André, 259. & (19) 34811802 \\
\hline Hotel São Pedro & 1973 & 4 & 20 & lazer & Praça Gustavo Teixeira, 775. & (19) 34811186 \\
\hline Hotel e Spa Jardim da Serra & 1999 & 25 & 50 & lazer/saúde & R. B, 24. & (19) 34612562 \\
\hline Hotel Trentin & & & 15 & lazer & Av. Imigrantes, 379. & (19) 34812363 \\
\hline Lago Azul da Serra Hotel Fazenda & 2008 & & 20 & lazer/rural & R. do Sol Nascente, 258. & (19) 34811507 \\
\hline Pau Brasil Hotel Fazenda & & & 20 & lazer/rural & R. 1, s/n Quadra K. & \\
\hline Pousada 3 Marias & 2001 & 1 & 8 & lazer & R. Brasil, 3 Quadra 8. & (19) 34833765 \\
\hline Pousada Bons Caminhos & 1999 & $2+2$ & 8 & lazer & R. Veríssimo Prado, 1300. & (19) 34812600 \\
\hline Pousada Cachoeira de Furnas & 1999 & 12 & 20 & lazer & Sítio Rancho Fundo. & (19) 34811114 \\
\hline
\end{tabular}




\begin{tabular}{|c|c|c|c|c|c|c|}
\hline Pousada da Lua & 1999 & 1 & 11 & lazer & Av. das Rosas, 14 Quadra 90. & (19) 34813221 \\
\hline Pousada dos Sonhos & & & 10 & lazer/rural & R. Itália, 13. & \\
\hline Pousada Fazenda Palmeiras & & & 5 & lazer & Rod. Ulisses Gumarães Km 22. & (19) 34811805 \\
\hline Pousada Recanto das Seriemas & & & 4 & lazer & Rod. Ulisses Guimarães Km 17. & (19) 34814339 \\
\hline Pousada Sétimo Céu & & & 8 & lazer & $\begin{array}{l}\text { Av. das Primaveras, Quadra 34, } \\
\text { Lote } 9 .\end{array}$ & (19) 34832983 \\
\hline Pousada Vale do Dinossauro & & & 10 & lazer & Rod. Elísio de Paula Teixeira, s/n. & (19) 34834545 \\
\hline Pousada Leite no Pé da Vaca & & & & lazer & $\begin{array}{l}\text { Estrada Municipal Elísio de P. } \\
\text { Teixeira Km 2,5 }\end{array}$ & \\
\hline Pousada Nova São Pedro & & & 4 & lazer & $\begin{array}{l}\text { R. Anatálio Fernandes Sanches, } \\
319 .\end{array}$ & (19) 34815951 \\
\hline Pousada Quinta dos Alpes & 2001 & 1 & 4 & lazer & $\begin{array}{l}\text { Av. das Begônias Quadra 4, Lote } 10 \\
\text { e } 11 .\end{array}$ & (19) 34815655 \\
\hline Pousada Samanbaia & 2004 & 4 & 10 & lazer/rural & Av. Sebastião Carreta, 1200. & (19) 34811565 \\
\hline Pousada Carpe Diem & & & 10 & lazer & R. Alcídio Scagnolato, 52. & (19) 34811805 \\
\hline Pousada Martelo & 2002 & $2+2$ & 14 & lazer & R. Barbosa, 150. & (19) 34811670 \\
\hline Pousada Portal & & & 8 & lazer & R. Failante Martinho Salvaia, 52. & (19) 34831949 \\
\hline Quintas dos Alpes Pousada & & & 4 & lazer & Av. das Begônias Lote 11. & (19) 34815655 \\
\hline Rancho do Tio Mário & & & 7 & lazer/rural & Av. dos Jasmins Quadra 77 Lote 6 & (19) 34813069 \\
\hline Santanas Ranch Hotel Fazenda & & & 12 & lazer/rural & R. das Esmeraldas, 337. & (19) 34812929 \\
\hline Serra do Itaqueri Hotel & 1989 & & 18 & lazer & $\begin{array}{l}\text { Estrada Municipal São Pedro a } \\
\text { Brotas Km } 12 .\end{array}$ & (19) 34816000 \\
\hline Thermas Water Park (Grupo J Andrade) & 1999 & 38 & 35 & lazer & Rod. SP 304 Km189. & (19) 31812111 \\
\hline Villa Vitta Hotel & 2005 & 18 & 33 & lazer/eventos/ecoturismo & Rodovia SP 191 Km 112. & (19) 34811726 \\
\hline \multicolumn{7}{|l|}{ Torrinha } \\
\hline Hotel & Fundação & Funcionários & UH's & Segmento Turístico & Endereço & Telefone \\
\hline Fzda Hotel Vale Verde Ltda Me & 1997 & 7 & 20 & lazer/rural & $\begin{array}{l}\text { Etr Vicinal Cesarino Mariano, } \mathrm{S} / \mathrm{N} \\
\mathrm{km} 95\end{array}$ & (14) 3656-6089 \\
\hline Hotel Alto Serra & 1997 & 4 & 26 & lazer & Av Odila Califf Della Coletta, 70 & (14) $3656-1310$ \\
\hline
\end{tabular}


Pous. Villa Serra de Torrinha Pous. Da Mãe Terra

$$
1900
$$
20053 temp. \begin{tabular}{l|l|l}
4 & 14 & lazer \\
\hline
\end{tabular}

20 lazer
Rua Nabor Marques, 497

Rod. Torrinha- São Pedro
(14) $3656-1092$

(14) 36226763 